CCopyright 2007

Jeremy S. Roethler 



\title{
Germany's Catholic Fraternities and the Weimar Republic
}

\author{
Jeremy S. Roethler \\ A dissertation \\ submitted in partial fulfillment of the \\ requirements for the degree of
}

Doctor of Philosophy

University of Washington

2007

Program Authorized to Offer Degree:

Department of History 
UMI Number: 3275907

Copyright 2007 by

Roethler, Jeremy S.

All rights reserved.

\section{INFORMATION TO USERS}

The quality of this reproduction is dependent upon the quality of the copy submitted. Broken or indistinct print, colored or poor quality illustrations and photographs, print bleed-through, substandard margins, and improper alignment can adversely affect reproduction.

In the unlikely event that the author did not send a complete manuscript and there are missing pages, these will be noted. Also, if unauthorized copyright material had to be removed, a note will indicate the deletion.

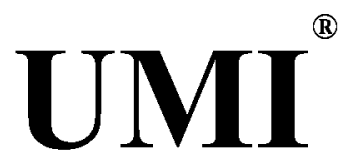

UMI Microform 3275907

Copyright 2007 by ProQuest Information and Learning Company. All rights reserved. This microform edition is protected against unauthorized copying under Title 17, United States Code.

ProQuest Information and Learning Company 300 North Zeeb Road

P.O. Box 1346

Ann Arbor, MI 48106-1346 


\title{
University of Washington \\ Graduate School
}

This is to certify that I have examined this copy of a doctoral dissertation by

\author{
Jeremy S. Roethler
}

and have found that it is complete and satisfactory in all respects, and that any and all revisions required by the final examining committee have been made

Chair of the Supervisory Committee:

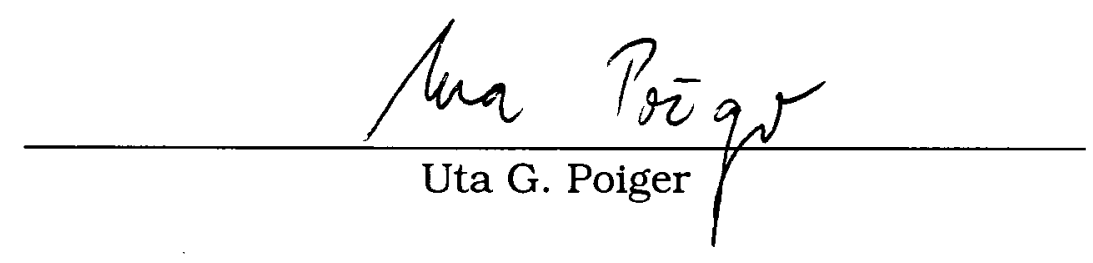

Reading Committee
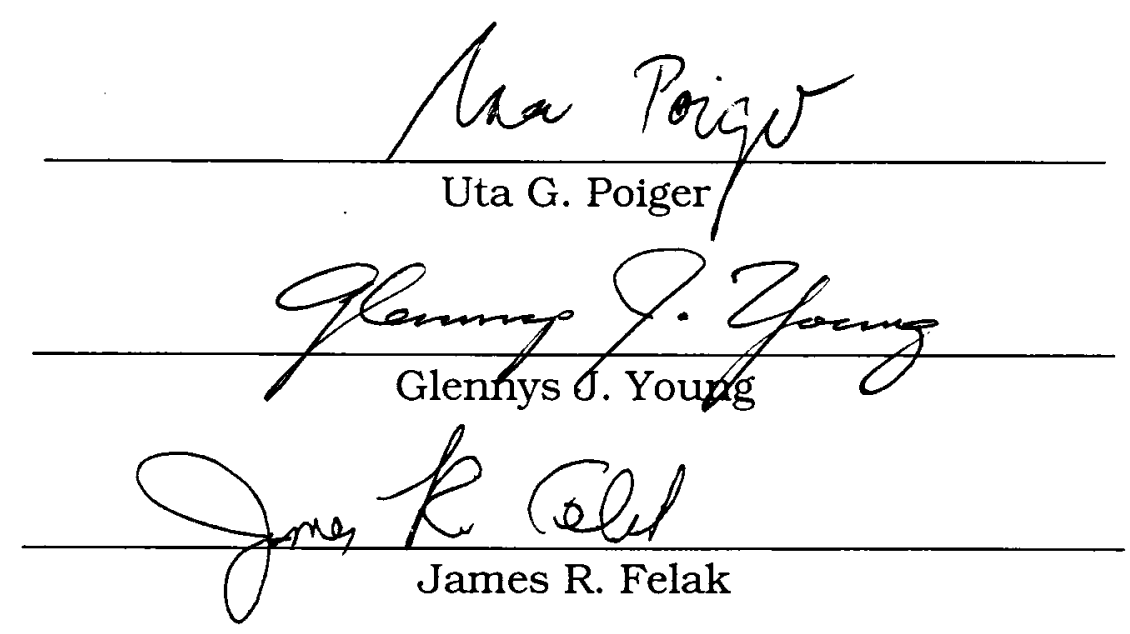

Date: $8 / 2 / 2007$ 
In presenting this dissertation in partial fulfillment of the requirements for the doctoral degree at the University of Washington, I agree that the Library shall make its copies freely available for inspection. I further agree that extensive copying of the dissertation is allowable only for scholarly purposes, consistent with "fair use" as prescribed in the U.S. Copyright Law. Requests for copying or reproducing of this dissertation may be referred to ProQuest Information and Learning, 300 North Zeeb Road, Ann Arbor, MI 48106, 1-800-521-0600, to whom the author has granted "the right to reproduce and sell (a) copies of the manuscript in microform and/or (b) printed copies of the manuscript made from microform."

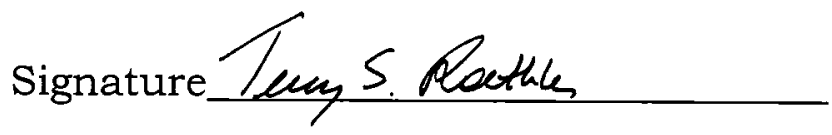

Date $8 / 7 / 2007$ 
University of Washington

\author{
Abstract \\ Germany's Catholic Fraternities and the Weimar Republic \\ Jeremy S. Roethler \\ Chair of Supervisory Committee: \\ Associate Professor Uta G. Poiger \\ Department of History
}

This project examines the relationship of Catholic fraternities to the politics and culture of the Weimar Republic (1918-1933). Through the last century, Catholic fraternity alumni have served as German chancellors, presidents, federal ministers, state executives, and leading voices in Germany's parliament. They have more broadly played leading roles in the Catholic press, in Catholic youth groups, in Catholic civic associations, and in the German Catholic hierarchy (including as archbishops and bishops). After World War II, Catholic fraternity alumni played founding roles in the Christian Democratic Union (CDU) and the Christian Social Union (CSU), the two parties that led West Germany's transition from its catastrophic defeat ("zero hour") to the economic miracle (1949-1969). This project considers the ideas that many of these Catholic leaders encountered as college students or as active alumni in their fraternities in the 15 years before Hitler came to power. The narrative begins by situating the fraternities in Germany's "Catholic Milieu" during and after the Imperial period (1871-1914) 
(Chapter 1). Three national Catholic fraternal organizations emerged on Germany's campuses at this time so that Catholics would have the opportunity to: bond socially and intellectually with other Catholics, remain loyal to their Church and their faith, and combat the profound discrimination and harassment they had experienced on Germany's campuses. The hostility articulated by nationalist students on German campuses towards their Catholic cohorts was part of the broader confessional antagonism that characterized German politics, society and economy at this time. This project focuses primarily on the dilemmas that Catholic fraternity members faced after World War I, including: constructing memories of their wartime experiences, and how these memories informed their understanding of Catholic confessional identity and German patriotism (Chapter 2); their attitudes towards German democracy and parliamentary institutions, using contemporary Catholic theology as a guide (Chapter 3); their willingness to remain loyal to the traditional political representatives of Catholicism (specifically, the Catholic Center Party) (Chapter 4); their attitude towards Marxism, Socialism and Communism (Chapter 5); their construction of German nationalism (Chapter 6); and their confrontation with National Socialism (Chapter 7). 


\section{TABLE OF CONTENTS}

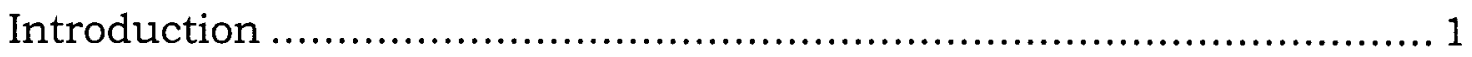

Chapter 1: Catholic Fraternities and Confessional Conflict ............... 38

Chapter 2: Catholic Fraternities at War ....................................... 82

Chapter 3: A Republic in Crisis................................................. 134

Chapter 4: Catholic Parties and Fraternity Politics....................... 190

Chapter 5: The Ethos of Catholic Community ............................ 228

Chapter 6: A Catholic Commentary on German Nationalism ........... 271

Chapter 7: The Catholic Fraternities and National Socialism........... 330

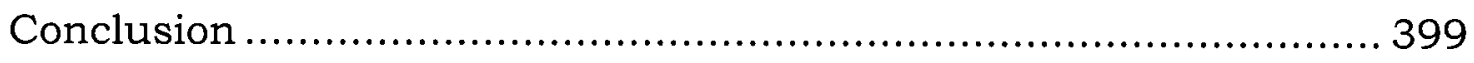

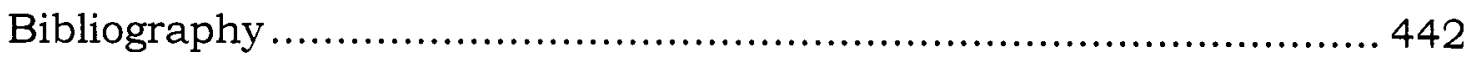




\section{ACKNOWLEDGEMENTS}

With sincerest gratitude to: Uta Poiger, Glennys Young, James Felak, John Toews and Sarah Stein. The University of Washington. Rondeau Evans and Macyln Burg. The Institut für Hochschulkunde (Würzburg), Ulrich Becker and his colleagues. The State Library of BadenWürttemberg (Stuttgart). Lori Anthony and Susanne J. Young. John Findlay. Raymond Jonas and Robert Stacey. Melissa Martin, Susan Smith, Vjeran Pavlacovic and Jennifer Price. Janet Tallman, JoLynn Edwards, Tim Taylor, Terry Taylor. Debra Allen and Richard Milk.

Cletus Weber, Elizabeth Peng and Aggie R. Hoffman. Jutta Landa. The Family Geiss (Munich, Nuremberg and Lake Forest, CA branches). The Family Porschitz (Neckarsulm-Amorbach). Ernest, Edward, Ralph and Stephen Lee Roethler. Linda and Paul Fischer. Duane Weilnau. Erika I. Gulyas. And Evelyn Dianne Roethler, my mother. 


\section{DEDICATED}

In Loving Memory to

May Townsend

1911-2006 


\section{Introduction}

In modern German politics, culture and society, Catholic fraternity members have maintained a prominent and resilient presence. Through the last century, members from Germany's Catholic fraternities have served as chancellors, federal ministers, presidents, state executives and leaders in parliament. In the church hierarchy, members of Germany's Catholic fraternities have served as archbishops, as cardinals and as popes. More broadly, Catholic fraternity members have served as leaders in German industry, in higher education, and in the deeply layered network of civic and cultural associations that has provided Catholic Germans with the means to affirm their distinct confessional identities in a predominantly Protestant and secular nation.

In the last full year of World War I in 1917, Germany's wartime leadership appointed Georg von Hertling as the first Catholic chancellor in modern German history. During the previous six decades, Hertling had played a founding role in the Catholic fraternity movement throughout southern and western Germany. Catholic fraternities contributed four more German chancellors in the Weimar period. They also contributed the first chancellor of the Federal Republic, Konrad Adenauer. Adenauer and a number of prominent Catholic fraternity 
allies spearheaded efforts to reconstruct the German nation after its catastrophic defeat in World War II. From 1949 to 1969, the Christian Democratic Union (CDU) and its Bavarian sister party, the Christian Social Union (CSU), dominated the German government at both the federal and state levels. At a time when these parties oversaw the transition from Germany's "hour zero" to its economic miracle, many, if not most of their leading figures hailed from Germany's Catholic fraternities. Virtually all of these leaders had been enrolled in the Catholic fraternities either as students or as active alumni in the decade or so before Adolf Hitler terminated Germany's republic in $1933 .{ }^{1}$

The influence of Catholic fraternity alumni in German politics is nothing short of remarkable. For most of the nineteenth century, and for much of the early twentieth century, the German government had treated its minority Catholics as national outcasts. The history of persecution against Catholics in Prussia, by far the largest and most important constituent entity of the German Empire or Kaiserreich, in fact, predated German unification by at least three decades. ${ }^{2}$ In the

\footnotetext{
${ }^{1}$ A fuller elaboration of the roles played by Catholic fraternity alumni in the politics of the Federal Republic is found in the Conclusion.

2 See Chapter 1. For a detailed summary of the prehistory of the Kulturkampf, see Michael B. Gross, The War Against Catholicism: Liberalism and the Anti-Catholic Imagination in Nineteenth Century Germany (Ann Arbor: The University of Michigan Press, 2005). The Kulturkampf was not just a Prussian phenomenon. In the 1870 s, as Gross explains, Liberals in Baden attacked Catholics as Reichsfeindlich-enemies of the Reich- and as an alleged fifth column of Catholic France. Gross, 236.
} 
decade after German unification in 1871 , as historian David

Blackbourn explains, the German government treated its Catholics "not so much as dissident citizens but, effectively, as inhabitants of an occupied state."3

The campaign against Catholicism after 1871 was known as the Kulturkampf or the struggle of civilizations. The Kulturkampf drove most of Germany's Catholic bishops and other religious officials into hiding, jail or exile. A prominent Catholic publicist at the time evocatively drew parallels between the Kulturkampf and Diocletian's campaign against the Christians of the Roman Empire at the turn of the fourth century. ${ }^{4}$ The Kulturkampf found considerable support in Germany's mainstream liberal and nationalist press organs. On college campuses, for reasons that will be explained, Catholics were no strangers to the profound enmity that confronted their coreligionists throughout the German Reich during this difficult period.

Wolfgang Altgeld writes that a "deeply rooted anti-Catholicism... through nationalism, penetrated democratic movements and liberalism in Germany." Wolfgang Altgeld, "Religion, Denomination and Nationalism in Germany," in Protestants, Catholics and Jews in Germany. 1800-1914, ed. Helmut Walser Smith (Oxford and New York, Berg, 2001), 53. In "Anti-Jesuitism in Imperial Germany: The Jesuit as Androgyne," appearing in the same edited collection of articles, Rosin Healy points out that the anti-Jesuit law was enacted by the German Reichstag and applied to the entire Reich, 153.

${ }^{3}$ David Blackbourn, Class, Religion and Local Politics in Wilhelmine Germany: The Center Party in Württemberg before 1914 (London: Yale University Press, 1980), 10.

4 David Blackbourn, The Long Nineteenth Century: A History of Germany, 1780-1918 (New York and Oxford: Oxford University Press, 1998), 262. 
Through the duration of the Kulturkampf, Catholic Germans flew papal flags and displayed papal colors, often, in flat defiance of the law. ${ }^{5}$ They willfully avoided Sedan Day and other nationally patriotic celebrations. ${ }^{6}$ They also hid priests and other Catholic officials who had been targeted for arrest. With the campaign against Catholicism an evident failure, Chancellor Otto von Bismarck terminated the Kulturkampf in the late 1870s. Nonetheless, until 1914, the German national government and many German states barred Catholics from serving in their most important civil service and public sector positions. Through the next several decades, hostile Protestant and nationalist leaders insisted that Germany would never find its rightful "place under the sun" as long as one-third of its population blindly obeyed a foreign pope who exerted his authority from beyond the Alps.

Acutely aware of their vulnerable status in German society and politics at the turn of the twentieth century, German Catholics nevertheless continued to affirm their faith and acknowledge the ethical and moral direction that it played in their daily lives. Through the Kaiserreich and after, to preserve their cultural distinctiveness,

${ }^{5}$ Blackbourn, The Long Nineteenth Century..., 298.

6 David Blackbourn, Marpingen: Apparitions of the Virgin Mary in Nineteenth Century Germany (New York: Alfred A. Knopf, 1994), 76-77. For an analysis of how some Catholic more broadly remained aloof from "mainstream" German reading culture, see also Jeffrey T. Zalar, "The Process of Confessional Inculturation: Catholic Reading in the "Long Nineteenth Century," in Catholics, Protestants and Jews in Germany. 1800 1914, ed. Helmut Walser Smith (Oxford and New York: Berg, 2001), 121-134. 
Catholics supported one of the most disciplined and organizationally formidable parties on Germany's political spectrum: the Catholic Center Party. They also participated in an increasingly dynamic network of Catholic civic organizations, think tanks, social clubs, Bible studies, literary societies, theology circles, labor organizations, and youth groups.

\section{The German Fraternity Movement and the Catholic Fraternities}

The German college fraternity movement derives its roots from efforts by German nationalists to mobilize college students against Napoleon's occupation in the first two decades of the 1800 s. The nationalist euphoria generated by Napoleon's defeat carried over in German universities after 1815. An incipient fraternity was first established at the University of Jena in that year. The German Fraternity (DB) was established three years later in $1818 .{ }^{7}$ As its name would suggest, the stated purpose of the DB was to promote German nationalism within the student body at a time when a unified German national state was little else but a vaguely imagined construct. Through the nineteenth and twentieth centuries, the DB remained Germany's largest and most influential national fraternal organization.

\footnotetext{
${ }^{7}$ Dietrich Heither, Michael Gehler, Alexandra Kurth and Gerhard Schäfer, Blut und Paukboden: Eine Geschichte der Burschenschaften (Frankfurt am Main: Fischer Taschenbuch Verlag, 1997), 287.
} 
In 1817 , at the Wartburg Festival, German nationalist students celebrated Martin Luther's departure from the Catholic Church in 1517 as a foundational moment in the history of the German national community. Through the nineteenth century, the DB and the similarly constituted nationalist organizations that emerged on German campuses saw Catholicism as antithetical to German national identity and German nation building. If Catholics on Germany's college landscape wanted the perceived benefits of fraternity membership, they would need to constitute fraternities on their own. They started to do so in the 1840 s, partially in response to the ignition of confessional hostilities in Prussia and elsewhere in the aftermath of the "Cologne Troubles" in 1837. The three major national Catholic fraternal organizations began to form in the Rhineland, Berlin, Breslau, Bavaria and Baden in the 1850 s and early 1860 s. These were known and still are known on Germany's campuses by their abbreviated names as the $\mathrm{CV}$, the $\mathrm{KV}$ and Unitas. ${ }^{8}$

As was the case with the German nationalist fraternities, members of the $\mathrm{CV}$, the largest of the three Catholic national fraternal organizations, wore fraternity colors and carried fraternity flags at university functions. Although the KV and Unitas fraternities did not

\footnotetext{
${ }^{8} \mathrm{~A}$ fuller elaboration of their official titles is found in Chapter 1.
} 
require members to wear fraternity colors, like the $\mathrm{CV}$, they had trial membership periods during which pledges were required to learn fraternity rituals, traditions and values. Starting in 1888 with the establishment of the CV's newspaper Academia, all three Catholic fraternal organizations produced regularly circulating periodicals that were made available to members throughout Germany. These newspapers allowed Catholic fraternity leaders and rank-and-file members to articulate their ideas on politics and Catholic confessional identity, among other things. Catholic civic, church and cultural leaders all contributed articles to these newspapers regularly. These newspapers reported on important events in Germany's Catholic community, including, for instance, annual Catholic rallies, which attracted Center Party politicians, members of Catholic youth, charity and labor organizations, and Catholic theologians, priests and bishops. At a more basic level, the national fraternity newspapers allowed members of individual chapters to report on everyday fraternity activities and to express their concerns to members of other chapters and to the national fraternity leadership.

Interaction in Germany's Catholic fraternities could be intimate, sustained and intense. Through the university years and well beyond, fraternity members lived, prayed, worshipped, ate their meals, hiked, 
played music and vented together. Membership in the Catholic fraternities extended well beyond the university years. Alumni paid fraternity dues and were entitled to participate in fraternity activities. Many of the most important ideas circulating in fraternity newspapers during the Kaiserreich and later were in fact authored by alumni. The fraternities served as directional stars for fraternity members well after their university years. Through the Kaiserreich and the Weimar period, prominent Catholic politicians and other leaders remained in close contact with their fraternity cohort decades after their university studies were over.

At the beginning of the twentieth century, the Catholic fraternities featured prominently in what contemporary commentators and later historians described as Germany's "Catholic milieu." The CV, the KV and Unitas fraternities were exclusive to practicing Catholics, meaning that their members were expected to attend mass, confession and communion regularly. As reported in the fraternity newspapers, participation in the holy sacraments of Catholicism was integral to fraternity functions. The fraternities were designed to allow Catholics to bond socially and intellectually at a time when Germany's Catholic Church authorities instructed their followers to confine themselves to

${ }^{9}$ Hermann Bahr, "Im Zeichen Weimars," in Wiederbegegnung von Kirche und Kultur in Deutschland, Eine Gabe für Karl Muth (Munich, 1927), 291. 
confessionally exclusive organizations. The Catholic fraternities (or at least so their members thought) tried to shelter members from the unrestrained excesses that supposedly defined traditional German fraternity life. Out of religious grounds, the Catholic fraternities also opposed mensur fencing, a form of ritualized duel that had been a mainstay in German student life for centuries. ${ }^{10}$

The rapid expansion of Catholic fraternity membership in Germany during and after the Kulturkampf signified in part a defensive reaction to the profound discrimination and harassment that Catholic students were facing on German campuses. Even after the campaign against Catholicism had been terminated at the national level in the 1880 s, confessional tensions continued to plague German universities for the next three decades. The "Academic Kulturkampf," as the tensions came to be known collectively, resulted in violence in the town of Jena on Ash Wednesday, 1904. This episode, which pitted dueling fraternity students against a newly formed Catholic fraternity chapter, sparked a series of similar campus confrontations across Germany. At a time when many German academics still charged that the Catholic faith could not be reconciled with modern scholarship, the proposed promotion of Martin Spahn, a Catholic history professor at the

10 The ubiquitous role of the duel in German campus life is explained in Chapter 1. 
University of Strasbourg, ${ }^{11}$ and an alumnus of the Catholic KV fraternity, both provoked and aggravated the conflict.

Through the next year following the Jena confrontation, nationalist and dueling fraternities descended on their respective university administrations and demanded that the Catholic fraternities be shut down. In an atmosphere of confrontation and mutual hostility, nationalist students on Germany's campuses alleged that the Catholic fraternities were serving as conduits for political Catholicism and papal meddling in German affairs. Ominously, they branded their Catholic counterparts as Reichsfeindlich, enemies of the German nation. Although confrontations between German nationalists and Catholics subsided in the last years prior to World War I, memories of confessional violence and hostility on Germany's campuses would remain deeply etched in Catholic minds for decades. In 1921, a handbook for Catholic fraternity students used words like "hate" and "fanaticism" to describe the attitudes that Germany's nationalist and dueling students held towards their Catholic colleagues. ${ }^{12}$

\footnotetext{
${ }^{11}$ Part of the German Empire from 1871-1918.

${ }^{12}$ Karl Hoeber, Handbuch für die Mitglieder des Verbandes der kath. Studentenvereine Deutschlands (Cologne, 1921), 46-55.
} 


\section{The Catholic Fraternities and Germany's New Republic}

At the outbreak of World War I in August 1914, Germany's emperor declared that he no longer recognized classes, parties or confessions, but only Germans. Many young Catholic soldiers were energized by a war experience that had seemingly eased Germany's traditional confessional hostilities. They likewise welcomed the war as an opportunity to prove their loyalty to a nation that had long questioned their patriotic credentials. At the conclusion of World War I, thousands of Catholic war veterans initiated or resumed their university studies. Like nearly all Germans, these Catholic veterans were devastated by a war that had ended disastrously for the fatherland. Many were also nervous about the revolutionary events that had overturned Germany's imperial government at the conclusion of the war. On August 11,1919, they were also aware that Germany's newly minted constitution guaranteed civic equality to Catholic Germans for the first time in their modern history. ${ }^{13}$

Most Catholic college students during the Weimar years joined the Catholic fraternity movement. In so doing, they reflected a broader trend within the German student body to use fraternities as a means to preserve the collective camaraderie of the war years. By 1931, the three

13 The Weimar constitution profoundly disappointed Catholics for reasons explained in Chapters 3 and 5. 
major Catholic national fraternal organizations enrolled approximately 18,000 members at a time when the German fraternity movement more broadly enrolled some 79,000 students, representing over $60 \%$ of the German student body. The DB continued to hold first place with approximately 11,600 members. The Catholic CV followed closely with approximately $10,000 .{ }^{14}$ First allowed to enter German universities at the beginning of the twentieth century, Catholic women during the Weimar period also continued to participate in a national fraternal organization. 15

Through the Weimar Republic, Germany's Catholic fraternities took credit proudly for the role that their alumni were playing in Germany's government as Center Party leaders. In a profound departure from the Kaiserreich, the Catholic Center Party played a leading role in the government of the Weimar Republic. The Catholic Center Party was involved in and in some cases led virtually every government coalition in Berlin between 1919 and the suspension of parliamentary government in 1930. An article appearing in a fraternity publication in 1924 offered a veritable who's who list of luminaries who had served or were currently serving in the Center - including Hertling,

\footnotetext{
${ }^{14}$ Hans Jürgen Rösgen, Die Auflösung der katholischen Studenten Verbände im Dritten Reich. Dortmunder Historische Studien. Bd. 15. (Universitätsverlag Dr. N. Brockmeyer, 1995), 181-182.

${ }^{15}$ Der Verband der katholischen Studentinen Vereine Deutschlands
} 
Ludwig Windthorst, Adolf Gröber, Felix Porsch, Ernst Lieber, Franz Hitze, Konstantin Fehrenbach, Joseph Mausbach, Wilhelm Cuno, and Wilhelm Marx. ${ }^{16}$ A number of early twentieth century German Catholic Church authorities, including Archbishops Adolf Bertram of Breslau and Michael von Faulhaber of Munich-Freising, were also Catholic fraternity alumni. During the Weimar period especially, Catholic fraternity alumni like Marx, Cuno, Spahn, Bertram and Faulhaber continued to play highly visible roles in fraternity functions.

Fraternities and their newspapers emphasized repeatedly the important contributions that their alumni were rendering in German public service. They likewise sought to convince new pledges that fraternity membership would prepare them for leadership roles in the Catholic community and the German nation more broadly.

At one time, membership in a Catholic fraternity had been a civic liability. One prominent Catholic recalled that he had withheld his son from the Catholic fraternities in 1897 because he feared that Catholic fraternity membership would hinder his later progress in the civil service or the army. "Second class citizens," "inferiority complex," and

16 San-Rat Dr. Hersting, "Verband-Politik," Akadem. Monatsblätter 37, \#1 (October 1924): 52-58. Among these, Fehrenbach and Marx served as German chancellors during the 1920s. Wilhelm Cuno also hailed from the Catholic fraternities, but was not affiliated with the Center Party. Heinrich Brüning became the fourth Catholic fraternity alumnus to serve as Germany's chancellor during the Weimar period in 1930. 
"ghetto mentality" had all been used to describe German Catholicism at that time. ${ }^{17}$ But, with all this supposedly part of Germany's past, little now stood in the way for Catholics on Germany's campuses to affirm their confessional affiliation. With the Catholic parties doing so well seemingly, fraternity membership could actually be of considerable benefit to a later career in politics and government service. Thus, Catholic fraternity membership continued to grow through the Weimar period.

Nonetheless, all was not well with confessional relations on Germany's campuses during the Weimar Republic. In the immediate years after World War I, Catholics studied under university faculties that, until very recently, had barred their doors to even the best Catholic scholars. During the Weimar years, Protestants, anticlerical liberals and conservative nationalists continued to represent the overwhelming majority of professors on Germany's campuses. At the beginning of the Weimar period, Catholics in a university lecture hall listened, as Max Weber, one of Germany's most respected scholars, explained the cultural roots of Protestant superiority and, conversely, Catholic inferiority. ${ }^{18}$ In the meantime, radical nationalists on

\footnotetext{
17 Hersting, "Verband-Politik," 55.

18 Max Weber, The Protestant Ethic and the Spirit of Capitalism (London and New York: Routledge, 1992), 35-41. See also Lucian Hölscher, "The Religious Divide: Piety in
} 
Germany's campuses continued to taunt Catholic fraternity members with the charge that Catholics were not to be counted among the trusted sons and daughters of the fatherland.

\section{Catholic Fraternities and the Emergence of National Socialism}

In the last years of the Weimar Republic, National Socialist students, who were by that time organized in a student union of their own, acquired an increasingly dominant position on Germany's campuses. Two years before Hitler's party assumed power on the national stage, National Socialist students and their allies had already secured a majority on Germany's national student body government. As early as 1923, when Adolf Hitler's attempt to overthrow the Bavarian government failed, student supporters of his movement marched through the streets of Munich and denounced the Catholic Church and its institutions. 19 The hostility between National Socialist sympathizers and Catholics continued through the decade. Through the first months of 1933, both the Catholic bishops and Catholic fraternity authorities tried to bar Catholic participation in National Socialist organizations.

Nineteenth Century Germany," in Protestants, Catholics and Jews in Germany. 1800 1914, ed. Helmut Walser Smith (Oxford and New York: Berg, 2001), 41. See Chapter 1 for a fuller explanation. As Hölscher explains, Weber's interest in this question was shared by contemporaries Ernst Troeltsch and Werner Sombart.

19 The reasons for this hostility will be explained in Chapters 3, 6 and 7 . 
Catholic fraternity members faced the same pressures as other students in the Weimar period, to name only a few: the formative experience of the Great War; socialist revolution and government crackdown; demobilization; the subsequent economic crisis; the pauperization of Germany's educated classes; anger over Germany's marginalized geopolitical position and doubts over the viability of a republic ripped asunder daily by squabbling politicians. These were precisely the same pressures that impelled thousands of German college students towards National Socialism years before Hitler's party would become a formidable force in German electoral politics. Catholic fraternity members did not, however, join the National Socialist movement in appreciable numbers until after 1933, when Hitler came to power and demanded that all independent associational life in Germany be "coordinated" 20 to the priorities of his regime. Even then, practicing Catholics remained conspicuously underrepresented in Hitler's regime and its organizations. ${ }^{21}$

20 One of Hitler's many fateful euphemisms. A better rendition for Gleichschaltung in this context would be "subordinated."

${ }^{21}$ See Chapter 7. As a testament to the durability of Germany's Catholic associational network, Catholics were very slow to leave their own youth, labor and professional organizations for their now mandatory Nazi counterparts. See Richard SteigmannGall, The Holy Reich: Nazi Conceptions of Christianity, 1919-1945 (Cambridge: Cambridge University Press, 2003). Of course, Hitler, Himmler, Heydrich and Goebbels had all been raised in the Catholic Church. Goebbels even belonged to one of the Catholic fraternities under investigation here until December 1918. But as 
During the Weimar period, Catholics had generally complied with the demands of their Church to stay away from the National Socialists. In 1933, when Hitler came to power, the Catholic Church retreated from its official hostility, however. In part, the hierarchy concluded, Church law obligated Catholics to obey their legitimately constituted authorities. Germany's President, Paul von Hindenburg, had appointed Hitler to lead Germany's government on January 30, 1933. Two months later, Hitler persuaded Germany's parliament to grant him dictatorial powers to deal with Germany's political and economic crisis. In the assessment of Germany's Catholic bishops, both actions seemed legal. ${ }^{22}$ The hierarchy also believed that its cooperation with Hitler's new government would help the Vatican secure its long sought goal of a Concordat with Berlin. Germany's Catholic bishops hoped that this Concordat would provide an important legal mechanism that would safeguard the Church's extensive associational network.

Insofar as the Catholic fraternities were concerned, this proved to be wishful thinking. Under pressure from the National Socialist

adults, all four expressed profound antipathy towards the church of their upbringing. Hitler claimed and wrote repeatedly that he favored German Protestantism. 22 As Robert A. Krieg points out, all of Germany's bishops in 1933 had come of age during the Kaiserreich. Among them, only one, Konrad von Preysing, Bishop of Berlin, had formal training in civil law. The rest had been trained mostly in canon or Church law. Preysing later became perhaps the most outspoken opponent of Nazism in the entire German hierarchy. Robert A. Krieg, Catholic Theologians in Nazi Germany (New York and London: Continuum, 2004), 21-22. 
authorities, the Catholic fraternities were first compelled to drop their explicitly confessional identities. By the late 1930s, all had dissolved. This turned out to be the fate of most independent Catholic organizations in the Third Reich. ${ }^{23}$ Still, many Catholics kept their distance from Hitler's regime, at least until 1939, when they again heeded the nation's call to arms. ${ }^{24}$

\section{Catholic Fraternities in the Context of Weimar Politics}

In the fifteen years prior to Hitler's rise to power in 1933, Catholic fraternity members left in their various publications a vast record of their ideas about Catholicism, democracy, capitalism, socialism, nationalism and their relationship as Catholics to the German nation. Through the duration of the Weimar Republic, Catholic fraternity members confronted critical questions, entailing explicitly national consequences. What lessons should they, as veterans, derive from the First World War? Should they endorse Germany's new republic or should they propose and promote something else? Should they stay neutral politically, should they endorse Germany's Catholic parties, or should they endorse some other party? How far should they go in rejecting the 1919 peace settlements that had badly damaged German

\footnotetext{
23 See Chapter 7.

${ }^{24}$ Gordon C. Zahn, German Catholics and Hitler's Wars (New York: E.P. Dutton \& Co., Inc., 1969).
} 
national interests? Did rejecting the Versailles treaty also mean advocating a revisionist war of revenge against Germany's enemies? Should they extend their hands to German-speaking students beyond Germany's borders, in Austria, Czechoslovakia and Poland? Should they admit converted Jews (or their descendants) to their ranks, when the nationalist fraternities typically did not? What should their position be on socialism and social democracy? Under what circumstances, if any, might they cooperate with the National Socialists and other rightwing nationalist organizations? What should they make of National Socialist ideology and doctrine? Were there any points of ideational similarity between Hitler's movement and the Catholic Church? From 1918 to 1933 , Catholic fraternity members were embedded in an increasingly complex network of confessionally affiliated organizations that extended well beyond the Church and its hierarchy. Their Catholicism powerfully informed their responses to many of these questions.

\section{Fraternities and the History of German Catholicism}

Much of the historical literature on the subject of German Catholicism rightly recognizes the significance of confessional division in the politics and culture of the Kaiserreich. But Thomas Nipperdey, Helmut Walser Smith, David Blackbourn and Margaret Lavinia 
Anderson, among others, have left the impression (not always deliberately) that Catholic confessional integrity at the beginning of the twentieth century was weakening, irreversibly, it seemed. ${ }^{25}$ Noel Cary largely affirms this portrayal when he extends the chronological horizon through the Weimar period and the early years of the Federal Republic. ${ }^{26}$ Once the Kulturkampf subsided and Catholic material conditions improved, the narrative often runs, fewer Catholics felt obligated to support the Center Party and other confessionally oriented organizations. Likewise, as Catholics became more urban, more professional and more educated, fewer adhered to the traditional requirements of the Catholic religion. This tendency is consistent with a paradigm prevailing in the social sciences in much of the twentieth century that understood secular modernity and Catholic religious identity to be contradictory.

Initiating a much needed revisionist trajectory, Margaret Stieg Dalton has recently explored efforts of Catholics from the Kaiserreich through the Weimar period to use the arena of culture to resolve the

\footnotetext{
${ }^{25}$ In addition to Blackbourn's study of the Center Party in Württemberg, see Thomas Nipperdey, Religion im Umbruch, Deutschland, 1870-1918 (Munich: C.H. Beck Verlag, 1988), Margaret Lavinia Anderson, Windthorst: A Political Biography (Oxford University Press, 1981), and Helmut Walser Smith, German Nationalism and Religious Conflict, 1870-1914 (Princeton University Press, 1985).

${ }^{26}$ Noel Cary, The Path to Christian Democracy: German Catholics and the Party System from Windthorst to Adenauer (Cambridge and London: Harvard University Press, 1996).
} 
"fundamental question of the extent to which they could accept the modern world yet still remain good Catholics."27 Robert A. Krieg and Thomas O'Meara have likewise explored this complicated and evolving relationship in the context of early twentieth century German Catholic theology. ${ }^{28}$ It is my contention that young Catholics in a highly influential formative leadership institution also wrestled with this dilemma in the context of German national politics. As Dalton, Krieg and O'Meara demonstrate, in the Weimar years, Catholic religious identity was not residual. This project similarly will show Catholic religious identity in the fraternities to be evolving, dynamic and imminent during this period of time.

Reflecting a broader trend in the literature on nationalism (see Chapter 6), scholars of German Catholic history likewise tend to see the choice between Catholic identity and German nationalism as a stark either/or. For instance, Smith, Heinz Hürten and Rudolf Morsey have all pointed to the decision of some members of the Center Party to support German militarism and colonialism during the last years of the

27 Margaret Stieg Dalton, Catholicism, popular Culture and the Arts in Germany, 18801933 (Notre Dame: University of Notre Dame Press, 2005), 3.

${ }^{28}$ Robert Krieg, Karl Adam: Catholicism in German Culture (Notre Dame: University of Notre Dame Press, 1992), Catholic Theologians in Nazi Germany (New York and London: Continuum, 2004), and Romano Guardini: Proclaiming the Sacred in a Modern World (Liturgy Training Publications, 1995). Thomas F. O'Meara, O.P., Erich Przywara, S.J.: His Theology and His World (Notre Dame: University of Notre Dame Press, 2002), and Church and Culture: German Catholic Theology, 1860-1914 (Notre Dame and London: University of Notre Dame Press, 1991). 
Kaiserreich as a means of emerging from their Kulturkampf-imposed defensive tower and entering the German political mainstream. ${ }^{29}$ As discussed below, Guenter Lewy, Gordon Zahn, Carl Amery, Daniel J. Goldhagen and Michael Lukens have pointed to this purported convergence between Catholic thinking and twentieth century German nationalism to explain Catholic complicity with the crimes of the Third Reich after 1933.

As this project will show, Catholic fraternity members during the Weimar years were intensely patriotic. These particular Catholics, however, were not using patriotism to redeem their supposed national inferiority complex. They likewise were not merely aping contemporary German nationalism in order to impress or appease German nationalists, including, ultimately, the National Socialists. As this project will show, these members of a highly influential formative institution for Germany's Catholic community tried to articulate their German patriotism in terms that remained consistent with and amenable to their Catholicism.

${ }^{29}$ Smith, German Nationalism and Religious Conflict..., 75. Heinz Hürten, Kurze Geschichte des deutschen Katholizismus 1800-1960 (Mainz: Mathias-GrünewaldVerlag, 1986), 163. Rudolf Morsey. "Die deutschen Katholiken und der Nationalstaat zwischen Kulturkampf und Ersten Weltkrieg," Historisches Jahrbuch 90 (1970): 31-64. 


\section{Chapter Outline}

In Chapter 1, I situate the German Catholic fraternity movements in the context of German confessional relations more broadly, and German student culture more specifically. I recount the controversies and challenges faced by Catholic fraternity students before World War I, particularly as they interacted with Germany's nationalist fraternities and related campus organizations. In the middle of the nineteenth century, Catholic fraternal organizations emerged largely in opposition to the nationalist ethos that had motivated Germany's mainstream fraternities. After German national unification in 1871 , leaders of the nationalist fraternities insisted that their Catholic counterparts were serving as conduits for a worldview that was inherently inimical to the interests of the German nation. Catholics fought this charge until 1914, when the requirements of national survival temporarily inspired civil peace on Germany's campuses.

In Chapter 2, I examine how Catholic fraternity members constructed their memories of World War I, a formative event for the development of German nationalism as a mass phenomenon. Regardless of their political or ideological proclivities, most Germans pointed to their participation in "the World War" with pride. Catholics were no exception. Contributors to the Catholic fraternity obituaries 
after the war were sure to emphasize the services that Catholic soldiers had rendered to the German fatherland. Catholic fraternity members were quick to emphasize the heroic qualities of fallen fraternity war heroes like Franz Laarmann, Joseph Hölling and Otto Lühr. They insisted that Catholic religious faith and practice had informed and motivated the heroism and virtue on the front demonstrated by their fallen brothers. Contributors to Catholic fraternity publications after 1918 had served on the front themselves, through four long years of hardship and battlefield horror. They largely rejected narratives offered by celebrated nationalist authors like Ernst Jünger; in so doing, they typically refused to romanticize the war or falsify its outcome. They also generally dismissed talk of embarking on a revisionist war of revenge. I conclude this chapter by considering the legacy of Albert Leo Schlageter, a Catholic fraternity member and a decorated World War I veteran. On May 26, 1923, the French authorities executed Schlageter after he had tried to sabotage their occupation of the German Rhineland. Through the 1920 s and early 1930s, Catholic fraternity publications frequently lauded Schlageter, who had died supposedly affirming both his loyalty to the fatherland and his dedication to his family, his Catholic fraternity, and his Church. At the same time, for reasons that will be explained, Germany's nationalists, including most 
prominently the National Socialists, tried to claim Schlageter as one of their own. At least until 1933, however, the Catholic fraternities refused to share the Schlageter legacy with their nationalist colleagues.

In $\underline{\text { Chapter } 3}$, I explore the attitudes held by Catholic fraternity members towards the institutions and political values underpinning the Weimar Republic. Radical nationalists on Germany's campuses complained that the Weimar Republic failed to embody the unique aspirations of the German nation. Catholic fraternity members too had many reservations about the republic and worried about the unsettled state of Germany's political institutions after 1918. They also worried about the post-war economic crisis that had devastated particularly Germany's students. In both affirming and criticizing the republic, Catholics relied on the evolving body of Catholic state doctrine that stretched as far back as the High Middle Ages, to St. Thomas Aquinas (1225-1274), the Angelic Doctor of the Catholic Church. Some of their ideas on politics and government claimed a genesis that reached back even further, to St. Augustine (354-430), and to Christian Scripture.

In Chapter 4, I consider the position that Catholic fraternity members maintained towards the broader Catholic political world, and particularly the Catholic Center Party. Although their alumni had served in prominent leadership roles in the Center Party for decades, 
the Catholic fraternities had stood officially neutral politically before

1918. After the war, returning Catholic veterans expressed their desire to prove their credibility as German patriots. Some Catholics believed that political activism was now unavoidable, if their fraternities were to play a truly constructive role nationally. Some believed further that their Catholic religious worldview must inform any political engagement. Many argued over the appropriate political directional star for Catholicism. Some Catholic fraternity members affirmed their loyalty to the Catholic Center or the Bavarian People's Party (BVP). Others refuted calls to support the Catholic parties, however. They agreed with Christian labor leader Adam Stegerwald that Catholicism offered "no universally valid" political direction. ${ }^{30}$ Some followed the lead of Martin Spahn, ${ }^{31}$ a prominent Catholic professor of the social sciences, and the son of respected Center Party politician Peter Spahn. After World War I, the younger Spahn defected from the Center and threw in his lot with the German National People's Party (DNVP). Catholics following Spahn's lead insisted that the Catholic worldview must be reconciled with German nationalism. Those who called for the

${ }^{30}$ Cary, 51. Stegerwald remained with the Center, but continually called on it to change its direction. Cary suggests that Stegerwald anticipated post-1945 West German politics, when Catholics no longer had the option of voting for a specifically Catholic party, but ultimately found their home in the inter-confessional CDU. 31 This was the same Spahn whose appointment in Strasbourg provoked the campus disturbances of 1904-1905. In 1918, Spahn was forced to leave Strasbourg after Versailles restored the city to France. 
reconstitution of their fraternities in order to allow members to play more meaningful political roles in German civic life provoked bitter disputes that were aired with embarrassing frequency in fraternity publications.

In Chapter 5, I consider how certain Catholic fraternity members constructed an explicitly Catholic ethos of community to reject: (1) German liberalism; (2) German capitalism; and (3) German Marxism in both its socialist and communist variants. Basing their reasoning on the lessons of St. Thomas Aquinas, these Catholics affirmed participatory (including parliamentary) government as a means of maximizing the normative content of the law. But, in keeping with the Angelic Doctor's prescriptions, Catholics generally rejected free market competition. They also rejected competitive party democracy, which they identified with liberalism. In their opinion, liberalism understood the political community as nothing more than a collection of discreet human beings seeking to use the state to promote their individual or special interests. In rejecting this notion, they charged that the Weimar constitution was not doing nearly enough to bring Germans together on a cooperative and corporative basis. These same Catholics found much in common with the Marxist protest against the class exploitation and alienation of workers under capitalism. But they nevertheless rejected 
Marxist class conflict. They also rejected Marxist revolutionary praxis as a breach of Catholic natural law.

These same commentators rejected the separation of Church and state that was supposedly embodied in the Weimar constitution. They also flatly dismissed the idea that the Catholic Church should be relegated to the status of a purely private association, with no role to play in German public life. Following a paradigm standard to Catholic political thinking, commentators in the fraternity newspapers continued to believe that the state and the church should be legally equal and distinct entities, "perfect societies," as contemporary Catholic theology held. But when it came to the family, education, and morality, among other things, they insisted that the jurisdictions of these two overlap. Although fraternity writers recognized that the Church could not expect to order "every little detail" of life, they insisted that the secular authorities do nothing to interfere with its moral prerogatives.

In $\underline{\text { Chapter } 6}$, I review the literature that seeks to understand the relationship between nationalism and confessional identity. I then examine what Catholic fraternity members said specifically about the relationship of their Catholicism to German national identity in the face of the growing nationalism and racism of the radical right during the last years of the Weimar Republic. In October of 1924, Dr, Berger, an 
alumnus of the Catholic KV fraternity explained in his fraternity's newspaper that he would very much like to know how his colleagues were defining German patriotism. Obviously annoyed by the insinuations from his nationalist colleagues that German patriotism depended on rejecting the republic, Berger also demanded to know how far German Catholics would have to tolerate the continued accusations of "weak national feeling." 32

Through the Weimar period, Catholic fraternity members articulated, in Catholic terms, complex and sophisticated ideas on what they thought the German nation should look like. Working through paradigms that anticipated more recent scholarly debates on nationalism, ${ }^{33}$ Catholic fraternity members in their periodicals attempted to define such elusive terms as state, nation, and national community. In so doing, Catholic fraternity members defined their national compatriots both in and outside of Germany's borders (in Austria, Poland and the Czech Sudetenland, for example) in ethnic, cultural and linguistic, but rarely racial terms.

The Catholic fraternities usually rejected the word "nationalism" in describing their support for the fatherland. They also rejected the

32 Dr. R. Berger "Einigung aller deutschen Akademiker," Akademischer Monatsblätter 37 (October 1924): 29.

33 Including the venerable work of Ernst Gellner, Benedict Anderson, Anthony D.

Smith and Eric Hobsbawm, among others 
word völkisch that was preferred by their nationalist cohorts. Instead, Catholics opted for Vaterlandsliebe, a term that in the German language translates literally into "love of the fatherland." ${ }^{4}$ In Vaterlandsliebe, explained Erhard Schlund, spiritual advisor of Germany's largest Catholic fraternal organization, one feels a sense of the fatherland in his or her heart, and is thereby compelled to promote and protect its interests through the conscious activation of the will. ${ }^{35}$ Nationalism, by contrast, he described as an "excessive love for the nation," as an exaggeration of national feeling that operated in the same way that egoism betrayed an exaggerated love of the self. Nationalism, he warned, recognized one nation opposed to all others, without respect to obligation or ethics. Nationalism, Schlund insisted, contradicted God's world order. It subverted the intention of God towards humanity and the world, which required the Christian believer to see all peoples as a familial community. "National and political fanaticism," he concluded, can never be confused with patriotism. "Love of your own people cannot be equated with hatred towards others." ${ }^{36}$

${ }^{34}$ Rendered throughout this discussion as "patriotism."

35 Von P. Erhard Schlund, O.F.M., CV-Seelsorger, "Katholik und Vaterland," Academia 44, Nr. 3 (June 15, 1931): 24.

36 Erhard Schlund, "Katholizismus und Nationalismus," Academia 39, Nr. 2 (June 15, 1926): 27. 
In Chapter 7, I examine the response of the Catholic fraternities to National Socialism, particularly its ideology and its positions on race and religion. The relationship between German Catholicism and Hitler's party (and later, Hitler's regime) has commanded considerable attention in the historical literature for the past five decades. ${ }^{37}$ Among others, Lewy, Amery, Zahn, and more recently (and forcefully), Goldhagen and Lukens, have all called attention to the purported ideological "points of contact" between contemporary German Catholicism and National Socialism. Their purpose is to evaluate the broader Catholic responses to (and complicity in) the crimes of Hitler's regime. Even if largely overlooked by this literature, the Catholic fraternities are very much part of this story. All Catholic fraternal organizations had dissolved before the onset of World War II in 1939. Nonetheless, the Internet websites for all three major national Catholic fraternal organizations today (2007) describe and explain the activities of the Catholic fraternities and their members when Hitler's party rose to prominence in the early 1930s, and after Hitler assumed control of the German government starting in $1933 .{ }^{38}$

${ }^{37}$ Chapter 7 includes a fuller engagement with this literature. 38 http://www.cartellverband.de, http://www.unitas.org, http://www.kartellverband.net 
Fraternity members during the early 1930 s authored numerous articles that prophetically and presciently located the dangers in National Socialism. They worried about Hitler's excessive and fanatical nationalism, which might endanger Germany's national survival. They also worried that Hitler would use the powers of the state to threaten the Catholic Church and its institutional prerogatives. Some accurately located the reasons why National Socialism appealed especially to Germany's youth. As one Catholic fraternity writer warned, National Socialism should be rejected, as should any form of political radicalism. Comparing Hitler's ideology to the heresies of the past, the writer explained that National Socialist ideology worked in "cheap black and white techniques." Nazism, like all radicalisms, should be seen as a "negation." Likewise, National Socialism was capable only of "primitive claims" that spoke to uncomplicated realities. National Socialism, the writer warned, could appeal to emotion and passion, not to ethics or reason. ${ }^{39}$

In its propaganda, the NSDAP made little secret of its demand to sever Germany's Jews (including Jews who had previously converted to Christianity) from the national community. But Hitler's plans to remove

\footnotetext{
39 Prof. Dr. V. Tischleder, Münster, i.W. "Der katholische Staatsgedanke als Echo der ursprünglichen gefundenen katholischen Wesensmitte," Akadem. Monatsblätter, 44, \#1 (October 1931): 120-126.
} 
Jewish influence from German national culture extended well beyond his call to marginalize Jews politically, economically, socially and physically. For instance, influential National Socialist propagandists called on Germany's Christian institutions to sever the "Jewish" Old Testament from the Bible and to rewrite the biography of Jesus Christ to "prove" his Aryan heritage. Some National Socialists also sought to eradicate Germany's confessional divide by incorporating Germany's Christians into an integrated national Church that would be united by the doctrine of "positive" Christianity. 40

The demand from a secular political movement to rewrite the Bible or revise the history of Christ's origins flatly contradicted Catholic doctrine. Similarly, the National Socialist demand for confessional integrity threatened the institutional prerogatives of the Church and reminded Catholics of their own awkward status as a confessional minority in a primarily Protestant nation. In rejecting National Socialist demands affecting Christian doctrine and worship, Catholic fraternity members before 1933 usually followed the lead of their Church. In the

${ }^{40}$ In addition to Steigmann-Gall, referenced above, see Robert P. Ericksen, Theologians under Hitler: Gerhard Kittel/Paul Althaus/Emanuel Hirsch (New Haven and London: Yale University Press, 1995); Alan Davies, Infected Christianity: A Study of Modern Racism (Kingston and Montreal: McGill-Queen's University Press, 1988); Julie M. Winter, Luther Bible Research in the Context of Volkish Nationalism in the Twentieth Century (New York: Peter Lang, 1998) and Robert P. Ericksen and Susannah Heschel (eds.) German Churches and the Holocaust: Betrayal (Minneapolis: Fortress Press, 1999). 
last years of the republic, Catholic fraternity members also presented their own compelling reasons for rejecting Hitler's positions on race and religion.

In their writings, Catholic fraternity members often betrayed a transparent hostility towards Germany's Jews. Much of this hostility confirmed the historical legacy of Catholic Judeophobia. For instance, Schlund tried to warn his fraternity readers that Jews were exerting a disproportionate and harmful influence on the German culture, economy and politics. On the other hand, Schlund reminded his Catholic readers that Christianity would be unthinkable without the historical service contributed by Judaism. For that reason, among many others, Jews were to be tolerated. Catholic fraternity members largely agreed with their Church that the National Socialist racial classification of Jews contradicted Church doctrine on the universal community. As Schlund wrote, the human soul is the creation of God alone, and therefore cannot be described racially. ${ }^{41}$ Catholic fraternity writers during the Weimar period rejected Nazi racism. They typically did not criticize Germany's Jews on racial grounds.

After Hitler came to power in early 1933, many other Catholic fraternity writers would nonetheless affirm the fundamental priorities of

${ }^{41}$ Von Dr. P. Erhard Schlund, Ve, O.F.M., "Zur Rassenfrage," Academia 40, Nr. 3 (July 15, 1927): 53-56. 
his regime. In particular, Hitler's call for a German national renewal that would organize German society on a cooperative and corporative basis impressed many Catholic fraternity members. These same fraternity members were not exactly bothered when Hitler drove Germany's parties underground and terminated parliamentary government. They approved when Hitler attacked the supposedly mortal enemy of Catholicism: Marxism. Through the spring and summer of 1933 , the Church hierarchy had seemingly made its peace with Hitler when it lifted its prohibition against Catholic membership in the NSDAP and helped to engineer a Concordat or formal treaty between Rome and Berlin. Even then, however, one fraternity writer feared that Hitler's drive to coordinate or subordinate all of German society to the dictates of his regime would spell doom for all independent Catholic associations, including the Catholic fraternities. As we will see in the conclusion, his fears were well founded. ${ }^{42}$

\section{Catholic Fraternities and the Federal Republic of Germany}

In 1938, the SS and the German police used the Third Reich's absorption of Austria as a pretext to outlaw Germany's remaining Catholic fraternities. Although some prominent members stayed in contact, the national organizations remained dormant through the end

42 Von Universitätsprofessor Dr. Eduard Eichmann, Mm, Ae, Bd., "Das Reichskonkordat und wir," Academia 46, Nr. 4 (August 15, 1933): 90-91. 
of the Third Reich. When these fraternities revived themselves after World War II, their leaders felt compelled to construct a narrative of resistance and opposition to Hitler and his regime. This was necessary to assuage the concerns of Western and Soviet occupational authorities who believed that fraternities historically had been hotbeds of German nationalism, proto-fascism, and anti-democratic sentiment. ${ }^{43}$

In the aftermath of World War II, Germans set out to rebuild their nation both physically and psychically. Catholic fraternity members stood at the forefront of these efforts. Even when it became clear that an exclusively Catholic political party would not revive in the late 1940s, Catholic fraternity alumni continued to play prominent roles in West German politics, especially in the CDU and CSU. Prominent Catholic fraternity alumni at this time, in addition to Adenauer, included Heinrich Lübke (West German President from 1959 to 1969), and CDU founders Otto Lenz, Hans Lukaschek, Heinrich Krone, and Heinrich von Brentano. Franz Josef Wuermeling, a parliamentary

${ }^{43}$ The historical literature on the broader fraternity movement largely confirms this assessment. This literature includes Jürgen Schwarz, Hans Jürgen Rösgen, Hans Peter Bleuel, Ernst Klinnert, Gerhard Schäfer, Dietrich Heither, Michael Gehler, Alexandra Kurth and Konrad Jarausch in the German language and Geoffrey Giles, Michael Kater, and Michael Stephen Steinberg in the English language. Many contributors have conceded (typically in passing) that the relationship between Catholic fraternities and Weimar was more complicated. Ultimately, the Western occupational authorities relented. The Soviet and German Communists in the Eastern Zone chose to keep the fraternities outlawed. They did not revive in the GDR until reunification in 1990 . 
representative of the CDU starting in 1949 and the highly influential Federal Minister for Family and Youth Questions through the 1950s, had been a founder of the CV chapter Wiking in Hamburg in 1919. Hermann Wellmanns, also a founder of Wiking in 1919, later played a central role in rebuilding the Central Association of German Trade ${ }^{44}$ starting in 1949. This same Wiking chapter also contributed Theodor Sanders, who was its last Senior Philister in 1933. In 1960, Sanders was serving as a judge on West Germany's highest judicial body in Karlsruhe. ${ }^{45}$ Catholic fraternity alumni such as Alfons Goppel and Hanns Seidel served the Federal Republic as state executives. The Hanns Seidel Foundation, established in 1967, continues to promote Christian values in German politics to the present day. Catholic fraternity alumni like Kurt Georg Kissinger and Franz Joseph Strauss would continue to feature prominently in West German politics during the 1960 s and 1970 s.

With German nationalism discredited completely in the wake of Germany's shattering defeat in 1945, all Germans, including Catholics, were required to revise substantially their understanding of politics and German national identity. In so doing, they drew strongly on ideas formulated in Catholic fraternities before 1933.

${ }^{44}$ Zentralverband des Deutschen Handwerks

45 http://www-wiking-hamburg.edu/index.php?id=14 (accessed August 5, 2007) 


\section{Chapter 1}

\section{Catholic Fraternities and Confessional Conflict}

The members of the Catholic fraternities do not believe it is sufficient in their student years to do nothing in the face of religious and moral degeneracy. Through their common efforts, they seek to promote and invigorate their religious consciousness. Kölnische Blätter, July 2, $1864^{1}$

This chapter provides an introduction to the subject matter that will form the basis of Chapters 2-7. In order to explain the role that Germany's Catholic fraternities played in both the larger national and university contexts during the Weimar period, this chapter will describe in order: (1) the sources of Germany's confessional hostilities in the nineteenth and early twentieth centuries; (2) the emergence of the German fraternity movement on Germany's college campuses around 1815; and (3) the emergence of Germany's Catholic fraternity movement approximately 40 years later. As this chapter will explain, the emergence of an exclusive and distinct Catholic German college fraternity movement is part of the broader story of confessional tension that characterized much of Germany's long nineteenth century.

\footnotetext{
${ }^{1}$ Excerpted in Karl Hoeber, Handbuch für die Mitglieder des Verbandes der kath. Studentenvereine Deutschlands (Cologne, 1921), 15.
} 


\section{Germany's Confessional Divide}

At varying levels of consistency, Catholics in Germany continue to affirm their faith by avowing the obligations of mass, baptism, confirmation, communion and confession. Representing approximately one third of the population of today's Federal Republic, Catholics participate in the dense, dynamic and resilient organizational network that has defined and structured their lives and the lives of their ancestors for centuries. In the idyllic southern and western German countryside, along the Rhine River, in the Black Forest and down the Romantic Road, ornately adorned Catholic churches present a dramatic contrast to the austere efficiency of Lutheran architecture elsewhere. Massive Catholic cathedrals tower over Cologne and Munich. In the fourth century of the Common Era, the Emperor Constantine's mother brought Christ's Holy Robe to the far Germanic outposts of the Roman Empire. In the ancient city of Trier, the Church of the Blessed Lady continues to guard its relics. In the forested hills of southern Germany, guest inns and cafes offer on their menus Maultaschen, or pasta packets of ground meat and spinach served in broth. In their Swabian dialect, locals tell visitors that their ancestors devised these culinary oddities in order to circumvent the traditional Catholic prohibition against eating meat on Fridays. Throughout southern and Rhineland 
Germany, the typically raucous festivals and parades marking the onset of Carnival offer a visual contrast to the quiet abstinence required of Catholics during the subsequent liturgical season of Lent.

The imprint of Catholic culture on Germany's landscape bears witness to broad, deep and politically significant confessional ruptures in past centuries. The Protestant Reformation (starting in 1517), the affirmation of princely prerogative in determining the religion of the realm and the ghastly wars of the sixteenth and seventeenth centuries opened a deep confessional fracture in the German speaking peoples of Europe. During the Enlightenment, Europe's most celebrated intellects targeted Catholic institutions with unforgiving hostility. Voltaire (16941778) held the monster of Catholicism responsible for the poverty, ignorance and superstition of Europe's masses. In the first years of the nineteenth century, Catholic Germans witnessed the formal dissolution of the Holy Roman Empire and the state acquisition of Catholic Church property. A generation later, Hegel and his disciples faulted the battered Catholic Church for failing to keep step with the progressive march of human freedom. ${ }^{2}$ Even when the Prussian leadership in

\footnotetext{
2 See in particular the third and last section of The Philosophy of History entitled, "The Modern Time." Here Hegel affirms Luther's revolt against the Church and explains the largely positive and productive impact of Lutheranism on the formation of the unitary state. According to Hegel, "the Council of Trent stereotyped the principles of Catholicism, and made the restoration of concord impossible." (418) Although the
} 
Berlin turned against Hegel's legacy in the early 1840s, Christian

Bunsen, a prominent advisor to King Frederick Wilhelm IV, continued

to describe the Catholic Church in unfriendly terms as "an obsolete

historical form of Christianity," and as "the primary hindrance to the

creation of a [German] national community." 3

German Romanticism inspired a temporary rehabilitation of

Catholicism. As the Enlightenment and its overemphasis on reason fell

from favor, Friedrich Schlegel converted to a faith that seemed to allow

a more sincere engagement with his emotions and intuitions. Catholic

literati Clemens Brentano and Joseph Görres found appeal in the

Romantic ideal seeking to restore the medieval organic community.

These same Catholics participated in the still vague German nation

building project, particularly in the efforts to excavate supposedly

Church ultimately succeeded in putting an end to the worst abuses that had provoked the Reformation "The Church came to a dead stop.... It severed itself from advancing Science, from philosophy and humanistic literature...." (419) "The Protestant Church increased and so perfected the stability of its political existence by the fact that one of the states which had adopted the principles of the Reformation raised itself to the position of an independent European power. This power was destined to start into a new life with Protestantism." (437) "After a free investigation in open day, Luther had secured to mankind Spiritual Freedom and the Reconciliation [of the Objective and Subjective] in the concrete: he triumphantly established the position that man's eternal destiny [his spiritual and moral position] must be wrought out in himself [cannot be an opus operatum, a work performed for him.] (441). Here, Hegel is clear that Luther advanced the cause of human freedom by trusting the individual to control his or her destiny through the application of free reason and rational thought, rather than simply following authority blindly, as the Catholic Church continued to demand. Georg Wilhelm Friedrich Hegel, The Philosophy of History (New York: Dover Publications, 1956). These lectures were delivered in the early 1820 s.

3 John Edward Toews, Becoming Historical: Cultural Reformation and Public Memory in Nineteenth-Century Berlin (Cambridge: Cambridge University Press, 2004), 93. 
authentic German national values buried deep in the memories of the medievalism. ${ }^{4}$ The leading forces behind German unification through the nineteenth century, however, preferred Protestantism. If for no other reason, most German nationalists believed that Luther's religion had been more consistent with the dictates and prerogatives of the unitary state. Unlike their Catholic counterparts, Lutherans especially in the German setting had been willing historically to subordinate their churches to the temporal authorities. For different reasons, Romanticism also fell from favor in Germany's literary mainstream. ${ }^{5}$ Through the nineteenth century, Prussia and other states in German Europe continued to reduce the Church's scope of cultural and political authority. Encroaching state governments frustrated the efforts of the Church to reign in a wayward flock that had supposedly

4 John Toews' recent contribution to the history of this period necessarily complicates the picture. Toews points out that in the 1840s, Prussian leaders like King Frederick Wilhelm IV revived a vision that might be described as a more mature Romanticism that respected the ruling institutions and practices of Germany's past, but was not one-dimensionally reactive to German liberalism or nationalism. Toews likewise points out that Prussian officials like Bunsen did not envision Germany's Protestant churches simply as handmaidens to the state. Bunsen believed that in order to maintain their credibility as inculcators of national and ethical values, the Protestant churches needed to maintain their independence from secular authorities. Interestingly (and almost assuredly unwittingly) Bunsen shared many of the same ideas on Church and state elaborated by Catholic fraternity commentators in the 1920 s, who likewise believed that only an independent church (in this case, Catholic) could inculcate the values necessary to revive and reconstitute a national community shattered by the Great War and its aftermath. (See Chapter 6.) Toews, 91-97. See also James Sheehan, German History. 1770-1866 (Oxford: Clarendon Press, 1989), 327, 336-337, 374-375.

5 Sheehan, 820-821. 
lost its connection to the most important elements of Catholic obligation and morality. In Prussia, for example, the law mandated that sons produced from mixed marriages be raised in the confession of their fathers. This law contradicted the Catholic marriage sacrament that demanded that all such children be instructed in the Catholic faith. In 1837, Archbishop Clemens August II of Cologne, a city incorporated into Prussian jurisdiction only in the last two decades, refused to sanction such marriages. For this intransigence, the archbishop found himself locked away in a Prussian jail. To the great surprise of the Prussian authorities, Catholics protested with massive popular demonstrations that came to be known as the "Cologne Troubles." 6

In the immediate aftermath, Görres, who had not made his living as an apologist for Church dogmatism, decried Prussian interference in Catholic affairs. From his relatively safe base in the heavily Catholic Bavarian city of Munich, Görres soon thereafter founded the periodical entitled The Historical-Political Pages for a Catholic Germany. ${ }^{7}$ Motivated by the growing animosity between Catholics and Protestants in Prussia and elsewhere, distinctively and openly Catholic press organs, scholarly

\footnotetext{
6 David Blackbourn, The Long Nineteenth Century, A History of Germany, 1780-1918 (New York and Oxford, Oxford University Press, 1998), 135. Sheehan, 617-618. Hajo Holborn, A History of Modern Germany 1648-1840 (Princeton: Princeton University Press, 1964), 504-506.

${ }^{7}$ Historisch-Politische Blätter für das katholische Deutschland
} 
circles and confessionally exclusive social organizations soon followed Görres' example. 8

As relations between Catholics and Protestants continued to sour, Catholic popular piety erupted through intense, spontaneous outbursts. ${ }^{9}$ In 1844 over one million Catholic pilgrims shocked liberal observers as they made their way to Trier to view the relics of Christ's Holy Robe. A Marian sighting in the western town of Marpingen three decades later attracted Catholic pilgrims from the far corners of German-speaking Europe and provoked widespread ridicule in the liberal press. Marpingen and spiritual outbreaks like it challenged the patience of anxious secular authorities. ${ }^{10}$

In the context of the Cologne, Trier and Marpingen events, the Catholic Church saw an opportunity to revive a Catholic discipline and observance that had seemingly degraded over the past centuries. ${ }^{11}$ The Church's attempt to discipline popular Catholicism partly responded to, and partly provoked accusations from skeptics that the faith had diverged from reason, rationality and the values of respectable society.

\footnotetext{
${ }^{8}$ Holborn, 504-506.

${ }^{9}$ Wolfgang Altgeld, "Religion, Denomination and Nationalism in Nineteenth Century Germany," in Protestants, Catholics and Jews in Germany, 1800-1914, Helmut Walser Smith, editor (Oxford and New York: Berg, 2001), 50.

10 David Blackbourn, Marpingen: Apparitions of the Virgin Mary in Nineteenth Century Germany (New York: Alfred A. Knopf, 1994), 27.

11 Michael B. Gross, "The Catholic Missionary Crusade and the Protestant Revival in Nineteenth Century Germany," in Protestants, Catholics and Jews in Germany, 1800 1914, Helmut Walser Smith, editor (Oxford and New York: Berg, 2001), 250, 257.
} 
The Church's critics complained that, in an age of progress, Catholicism seemed to be turning backwards and inwards. At the mid-point of the nineteenth century, German Protestants had followed the lead of Friedrich Schleiermacher by distancing their faith from mystic ritual and Biblical mythology. By contrast, the Vatican galvanized and mobilized its followers by dogmatizing the Virgin's Immaculate Conception and institutionalizing the Cult of the Sacred Heart. Amazed at what they saw as a theologically inspired revival of mythology, idolatry and superstition, critics charged that Catholicism had become the repository for suspect morality and anti-modernist obscurantism. ${ }^{12}$

In the face of gathering momentum for German unification at the midpoint of the nineteenth century, Catholics found themselves on the outside looking in. Historically, Catholic loyalties had been oriented regionally and provincially. To the extent that Catholics at this time could be described as German nationalists, they preferred the idea of a "greater" Germany that would encompass and be led by Catholic Austria. But, after 1848, Catholics had to look on in disappointment, as the compass for unification pointed increasingly in the other direction, to the north, towards Protestant, anti-Catholic Berlin. Eager

\footnotetext{
12 Roisin Healy, "Anti-Jesuitism in Imperial Germany: The Jesuit as Androgyne," in Protestants, Catholics and Jews in Germany, 1800-1914, Helmut Walser Smith, editor (Oxford and New York: Berg, 2001), 159.
} 
to eliminate the Catholic Habsburg dynasty as a potential rival to the Protestant House of Hohenzollern, Protestants advocated for a "smaller" Germany that would exclude Austria. The smaller Germany vision won out in 1866, when the Prussian army routed its overmatched Austrian counterpart at Königgratz. The victory assured Protestant hegemony in German Europe. It also assured that, from 1871 onward, Catholics would be a minority in the German Reich.

Tellingly, in 1866, Catholics from Bavaria and elsewhere fought and lost with Austria. Anger over the war's outcome morphed into violence in the town of Lampheim, Württemberg, where Catholic mobs tried to destroy a newly constructed Lutheran Church. ${ }^{13}$ Hermann von Mallinckrodt, then leader of the Catholic Center Party in Prussia, confirmed glumly at the conclusion of Prussia's victory: "the world stinks." Two years later, Georg von Hertling, a private lecturer at Bonn University, a founding figure in the Catholic fraternity movement and a prominent Catholic Center Party politician, ${ }^{14}$ kept well out of sight, while his Protestant colleagues celebrated the triumphant arrival of the Prussian King and future Kaiser of Germany. ${ }^{15}$ On the other side of the confessional divide, Protestants hailed the 1866 "crusade" as a

${ }^{13}$ George C. Windell, The Catholics and German Unity, 1866-1871 (Minneapolis: University of Minnesota Press, 1954), 6-8.

14 and in the last years of the First World War, Chancellor of the German Reich 15 Windell, 4-5. 
vindication for Luther, as the completion of the Reformation, and as the final victory of German Protestantism over Catholicism. ${ }^{16}$

In 1864 , less than a decade before Germany's unification, Pope Pius IX denounced in his Syllabus of Errors a host of political and scientific ideas that nineteenth century reformers had cherished as symbols of secular progress. Six years later, through a major Church council, the Pontiff reasserted the doctrine of papal infallibility. The Pope's affirmation of total papal authority in all matters spiritual and secular came to be known as Ultramontanism. The demand that Catholics behold a supra-national authority "beyond the mountains" provoked a schism in Catholicism itself and alarmed state leaders across Europe. ${ }^{17}$ Otto von Bismarck believed that Ultramontanism and loyalty to the newly minted German Reich could not be reconciled. Bismarck cited Ultramontanism as his primary justification for launching the Struggle of Civilizations, or the Kulturkampf, against Church officials and politically active Catholics in the first decade after German unification.

Germany's liberals and Protestants affirmed Bismarck's drive to sever Catholics from the still pervasive institutional influence of the

\footnotetext{
${ }^{16}$ Lovell Ellen Evans, The German Center Party: 1870-1914. A Study in Political Catholicism (Carbondale: Southern Illinois University Press, 1981), 26.

17 Somewhat counter-intuitively, those who rejected infallibility were known in Germany as "Old Catholics."
} 
Church hierarchy. In so doing, they hoped to hammer Catholics more firmly into the German national edifice. Spearheaded by Adalbert Falk, Minister of Education for the largest constituent principality of the new Reich, the war against Catholic civilization in the 1870s and 1880s unfolded on a number of fronts. Early on, the Prussian authorities threatened traditional Church prerogatives in educating young Catholics by inspecting the instructional content of Catholic confessional schools. They similarly imposed state control over the appointment and education of priests. They required priests to possess German citizenship and pass examinations in German history and culture. Prussia also threatened to withdraw financial support from Church districts that failed to cooperate with government policy. On the national level, Bismarck also secured the deportation of the Jesuits and the expulsion of Germany's remaining Catholic monastic orders, including those that had fed and cared for the Catholic poor. In support of the campaign against Catholicism, the Prussian authorities turned against both clergy and layperson. In the aftermath of the Marian apparitions, police raided Catholic press organs like the Berlin- 
based Germania. More ominously, Bismarck accused the Catholic Center Party of serving as a "fifth column" for Catholic France. ${ }^{18}$ Historians may always disagree on the real motives behind Bismarck's national "struggle for civilization in the interests of humanity." 19 In appraising the severity of his campaign against German Catholicism, however, there are few issues on which the notoriously conflicted historiography of the Kaiserreich finds more agreement. Ronald Warloski has argued that the forces behind national unification excluded Catholicism as a symbol of "everything outdated, reactionary and bad." 20 Volker R. Berghahn writes that Bismarck's campaign, significant of a broader tendency to identify internal enemies of the state in order to consolidate domestic politics, "greatly impeded the work of the Catholic church and the Center Party and to some

18 Blackbourn, Marpingen..., 211. Noel Cary, The Path to Christian Democracy: German Catholics and the Party System from Windthorst to Adenauer (London and Cambridge: Harvard University Press, 1996), 15-17.

19 A statement attributed to Rudolf Virchow, Gordon Craig, Modern Germany 18661945 (New York and Oxford: Oxford University Press, 1978), 74. Craig points out that before unification, Bismarck had usually navigated decent relations with the Vatican and did not seem to harbor ill will against Catholicism per se. Berghahn and earlier, Hans-Ulrich Wehler have left the impression that Catholics served as convenient targets in a broader tendency of the Kaiserreich to pursue "negative integration" that also singled out liberals, Socialists and ultimately, Jews. The motive drive behind these campaigns was not nationalism, but Bismarck's desire to preserve the essentially authoritarian, anti-democratic constitutional structure of the Reich. HansUlrich Wehler, The German Empire 1871-1918 (Lemington Spa, Hamburg and New York: Berg Publishers, 1985), 90-91.

${ }^{20}$ Ronald Warloski, Neudeutschland, German Catholic Students, 1919-1939 (The Hague: Martinus Nijhoff, 1970), preface, xvi. 
extent even made it altogether impossible."21 David Blackbourn tells us that Germany's authorities treated Catholics "not so much as dissident citizens but, effectively, as inhabitants of an occupied state."22 Geoff Eley agrees, and adds that Germany's leadership singled out Catholics as a clear and present danger to the still delicate nationbuilding project. ${ }^{23}$ Writing from a different angle, Alan Davies has postulated that the Kulturkampf signaled the unwillingness of Germany's nationalists to tolerate confessional diversity in the new nation-state. Nationalists instead advocated a new, consolidated Christian identity that would prefigure Nazi "positive Christianity" decades later. ${ }^{24}$

Hostility to Catholicism took organized form at the grass-roots level with the formation of the Protestant League in 1887 . With a membership estimated at 500,000, the Protestant League sought to purge alleged Catholic influence from German national culture. Prominent members of the Protestant League_included Otto Everling, Johannes Hieber, Paul Bränlich, Hermann Kremers, and Friedrich Meyer. Many of these members defined the German race as eminently

21 Volker R. Berghahn, Imperial Germany 1871-1914 (Providence and Oxford: Berghahn Books, 1994), 268.

22 David Blackbourn, Class, Religion and Local Politics in Wilhelmine Germany: The Center Party in Württemburg before 1914 (London: Yale University Press, 1980), 10. 23 Geoff Eley, From Unification to Nazism (London: Routledge, 1986), 61.

${ }^{24}$ Alan Davies, Infected Christianity: A Study of Modern Racism (Kingston and Montreal: McGill-Queen's University Press, 1988), 41. 
Protestant and denounced Catholicism as a handicap in Germany's national struggle against culturally more homogenous foes. Leading members of this organization continued to equate Catholicism with low literacy, mass superstition, chronic poverty and political disunion. In the narrative of historian Helmut Walser Smith, one prominent Protestant at this time described Catholicism as Germany's "cancerous affliction." 25

Even with Germany's Catholic bishops and other ecclesiastical officials in hiding, in jail or in exile, however, the Kulturkampf had failed to intimidate Catholics to turn away from their Church. Catholics fought the campaign through civil disobedience and increasingly disciplined displays of public solidarity. Priests continued to minister their flocks, even after being dismissed by the authorities. Catholics hid priests when the authorities threatened to punish their intransigence with arrest and incarceration. ${ }^{26}$ Facing opposition from within his own conservative base and grudgingly acknowledging the Church's ability to mobilize a still loyal Catholic following, Bismarck turned his energies elsewhere. At the termination of the Kulturkampf, Catholics stood mobilized politically and organizationally as never

\footnotetext{
${ }^{25}$ Smith, German Nationalism and Religious Conflict..., 27-30, 60-61.

26 David Blackbourn, The Long Nineteenth Century: A History of Germany, 1780-1918 (Oxford and New York: Oxford University Press, 1998), 298-299.
} 
before. The unsuccessful struggle to galvanize German national sentiment served only to widen the confessional fissure running through the nation.

In the decades after Prussia's resounding victory in the 1871 war with France, Catholics stood stubbornly aloof from mainstream German nationalism. Critics complained that Catholics intentionally avoided patriotic events like Sedan Day. ${ }^{27}$ Catholics also reacted lukewarmly to the imperialist aspirations of the Reich. They offered little in the way of support to grass-roots nationalist organizations like The Pan German League, The Imperial League, or The Society for Germans Abroad. ${ }^{28}$ More seriously, in the decades after unification, some Catholics favored the flag of the Vatican over the flag of the newly minted Germany and flew the Papal colors in clear defiance of the national state, even if doing so violated the law. ${ }^{29}$

A leading nineteenth century Catholic historian, Johannes Janssen, nettled his Protestant and nationalist readers when he described the late fifteenth century, before the Protestant Reformation,

27 David Blackbourn, Marpingen...,77.

${ }^{28}$ Smith, German Nationalism and Religious Conflict..., 148-149.

${ }_{29}$ Blackbourn, The Long Nineteenth Century..., 298. 
as the golden age in German history. ${ }^{30}$ Along a similar line of historical thinking, Catholic historians ridiculed the seemingly disingenuous attempts of their Protestant colleagues to elevate into the German national pantheon Gustavus Adolphus, Swedish hero of the Thirty Years war. ${ }^{31}$ Influential Catholics in reading clubs and theology circles did not apologize for but, indeed, took pride in their deliberate rejection of secular scholarship.

For many decades after the Kulturkampf, Germany contained two different, largely exclusive cultural worldviews, one Protestant and one Catholic. As Blackbourn writes:

Protestants and Catholics not only had their own brands of faith; they had their own literary canons, their own historical pantheons - their own sense of what it meant to be German. Far from being a mere residue of distant religious struggles, these separate identities were becoming more distinct again in the third quarter of the nineteenth century. ${ }^{32}$

On one side, the Catholic hierarchy and its allied press organs sheltered Catholic followers from the influence of allegedly Protestant, liberal and modern ideas. On the other side, Germany's mainstream literary canon excluded Catholic literati and scholars. Celebrated Catholic epic poet

30 Smith, German Nationalism and Religious Conflict..., 63-75. Gabriele Clemens, Martin Spahn und der Rechtskatholizismus in der Weimarer Republik (Mainz: MatthiasGrünewald-Verlag, 1983), 27.

${ }^{31}$ Kevin Cramer, "The Cult of Gustavus Adolphus: Protestant Identity and German Nationalism," in Protestants, Catholics and Jews in Germany, 1800-1914, Helmut Walser Smith, editor (Oxford and New York: Berg, 2001), 111.

32 Blackbourn, The Long Nineteenth Century..., 286. 
Friedrich Wilhelm Weber represented only one among many examples of Catholics that the mainstream German reading public censored due to their allegedly Ultramontane proclivities. ${ }^{33}$

In the first decades of the twentieth century, Protestant and liberal leaders in Germany fretted openly over the prospects of building a nation that harbored a substantial and stubborn confessional minority. Protestant Church historian Adolf von Harnack warned that Germany's confessional divide would jeopardize national unity. Over three decades after Prussia's victory over France had sealed nominal German unification, the historian Max Lenz in 1907 complained that "national unity is not complete as long as our worship of God is not on common ground." 34

As they entered the twentieth century, Germany's Catholics faced frequent reminders of their historic marginality in German society. In a series of articles that would later form the basis for his now famous and still widely assigned study on the relationship between Protestant culture and capitalism, Max Weber attested that German society continued to exclude its Catholics from nearly all significant academic and public sectors. Weber similarly reiterated (even if he would not

\footnotetext{
33 Jeffrey T. Zalar, "Catholic Reading in the 'Long Nineteenth Century", in Protestants, Catholics and Jews in Germany, 1800-1914, Helmut Walser Smith, editor (Oxford and New York: Berg, 2001), 125.

${ }^{34}$ Smith, German Nationalism and Religious Conflict..., 55, 162.
} 
confirm) the long held stereotype that Catholics preferred the stable, if stagnant life of economic security. The moral economy of Catholicism represented a distinct contrast to a Protestant ethic supposedly driven by initiative and industriousness. As Weber put it, “...the proverb says jokingly, 'either eat well or sleep well.' In the present case the Protestant prefers to eat well, the Catholic to sleep undisturbed." 35

At the beginning of the twentieth century, most Catholics lived in Germany's rural and small-town districts. They worked as small farmers, artisans, shopkeepers and carpenters. ${ }^{36}$ In Germany's western cities, Catholics worked in the most difficult industries such as mining. Conversely, Catholics were rarely found among entrepreneurs, civil servants or salary-earning professionals. Statistics compiled during the early twentieth century confirm a picture of a Catholic subculture living economically in the shadow of the Protestant mainstream. While constituting one-third of the population of Prussia in 1908, Catholics contributed only one-sixth of the tax revenues in Germany's largest and most important constituent state. ${ }^{37}$ Protestants predominated in

\footnotetext{
${ }^{35}$ Max Weber, The Protestant Ethic and the Spirit of Capitalism (London and New York: Routledge, 1992), 35-41.

${ }^{36}$ David Blackbourn, Class, Religion and Local Politics in Wilhelmine Germany: The Center Party in Württemburg before 1914 (London, 1980), 43. Willfried Spohn, "Religion and Working-Class Formation in Imperial Germany, 1871-1914," in Society, Culture and the State in Germany, 1870-1930, Geoff Eley, editor (Ann Arbor: University of Michigan Press, 1996), 168.

${ }^{37}$ Blackbourn, Class Religion and Local Politics in Wilhelmine Germany..., 32.
} 
Germany's national and local government offices. Four Catholics found company among the ninety ministers and state secretaries serving the Prussian state government between 1888 and 1914. According to records in 1896, Catholics constituted only nine percent of the private docents, ${ }^{38}$ twelve percent of adjunct lecturers, and seventeen percent of the tenured professors serving in Prussia's non-theological university faculties. At Freiburg University, located in heavily Catholic Baden, Catholics made up less than ten percent of the faculty. ${ }^{39}$ These disparities, while progressively shrinking at the turn of the twentieth century, persisted though the interwar period.

\section{Origins and Structure of the German Fraternity Movement}

Germany's Catholic college fraternities first emerged around the 1840s. By that time, German speaking universities had known nationalist oriented fraternal organizations for over a generation. Germany's fraternal student organizations owe their origins to at least two distinct historical traditions. Before 1800 , the customarily aristocratic student "compatriots associations" 40 united members hailing from the same geographic origins. By 1800 , these associations

\footnotetext{
38 Privatdozenten: independent scholars, who made their living by charging students fees for instruction.

39 Blackbourn, Class Religion and Local Politics in Wilhelmine Germany..., 32.

Warloski, preface, xxiii.

40 Landsmannschaften
} 
had transformed themselves into exclusive student corps. In 1815 , following Napoleon's expulsion from German Europe, the corps were joined by the student fraternities ${ }^{41}$ pioneered by University of Berlin Professor Friedrich Ludwig Jahn. Members of the fraternities organized along democratic lines, carried their own flags, including the predecessor of today's red, black and gold flag of the Federal Republic of Germany, and wore colorful caps, sashes and jackets. Through their highly public ceremonial activities, the fraternities sought to instill German national values among their members and in the broader student population. ${ }^{42}$

Through the nineteenth and early twentieth centuries, the sons of titled aristocrats continued to enroll in the elite corps, while the offspring of the middling and professional classes joined the somewhat less prestigious fraternity associations. But, as historians of the German fraternity movement tell us, by the late nineteenth century, the

\footnotetext{
41 Burschenschaften

${ }^{42}$ Hans Jürgen Rösgen, Die Auflösung der katholischen Studenten Verbände im Dritten Reich, Dortmunder Historische Studien, Bd. 15 (Universitätsverlag Dr. N. Brockmeyer, 1995), 8-12. Michael H. Kater, "The Work Student: A Socio-Economic Phenomenon of Early Weimar Germany," Journal of Contemporary History 10 (1975), 73. Michael Stephen Steinberg, Sabers and Brown Shirts: The German Students' Path to National Socialism (Chicago: University of Chicago Press, 1973), 12-13.
} 
corps and the fraternities had converged in many, even if not all, of

their essential structures, practices and functions. ${ }^{43}$

Before World War I, the fraternities and corps provided students

on German campuses with practically the only organized social

43 Rösgen, 8-12. Kater, 73. Steinberg, 12-13. For ease of explanation, the corps and fraternities are treated in this narrative as part of the same essential tradition. But, as historians of Germany's student culture also recognize, important distinctions divided the two well into the Weimar period. Deriving from an older, aristocratic legacy, the corps staunchly supported German monarchism and militarism, but, were not as likely as the fraternities to be impressed by German nationalism. Perhaps surprisingly, the most elite of the corps were among the last institutions on Germany's campuses to resist the racial policies of the Third Reich, most notably, refusing to expel Jewish-descended alumni from their membership rolls. All fraternal organizations maintained individual university chapters (known by any of the following: Korporation, Burschenschaft, Verbindung, Verein or Bund), but unlike American fraternity chapters (consistently identified by Greek letters), these often had their own unique names. The word Burschenschaft was used officially by the nationalist German Fraternity (Deutsche Burschenschaft), although the term could be used unofficially to describe any fraternity hailing from the nationalist tradition. Other fraternities used the title of Bund, such as the Akademischer Turnbund or the Allgemeine Deutsche Burschenbund. Finally, some used the term Verbindung, as in, the Verband der akad. Sportverbindungen. The older Corps did not officially use any of these titles, but used the abbreviated appellation SC (Senioren-Convent) at the end of their names, as in, the Kösener SC. The Corps and the nationalist oriented Burschenschaften, Verbindungen and Bünde generally endorsed the duel and, later, joined to form the Allgemeiner Deutscher Waffenring, a highly visible organization during the Weimar years. The Protestant confessional unions, which opposed the duel, usually used the term Bund. (The tiny Jewish fraternities, including the KartellConvent, the Bund zionistischer Korporationen, the Kartell Jüdischer Verbindungen and the Bund jüdischer Akademiker were nearly always excluded from national fraternity life.) For the Catholic confessional organizations (all opposed to the duel), the terminology is more complicated. The three largest Catholic organizations used the general term Verband to describe the national umbrella entity. As will be explained later in this chapter, the Verband had its own leadership, set the rules for individual fraternity chapter practice, represented the fraternity chapters at the national level and organized national fraternity activities and conferences. At the local level, the color-wearing Catholic chapter fraternities of the CV called themselves Verbindungen (Cartellverband der katholischen deutschen Studentenverbindungen). The non-color wearing fraternity chapters of the KV and Unitas elected to use the more general term Verein, although both otherwise followed fraternal forms of practice and organization. Later, the color-wearing Catholic Ring, formed in 1924, notably elected to use the term Burschenschaft. As was generally the case with other fraternal organizations on Germany's campuses, each Catholic fraternity chapter had its own unique name, as in, the Aenania chapter of the CV at the University of Munich. 
infrastructure. ${ }^{44}$ The integrative mainstays of today's student life, dormitories, cafeterias and student unions, did not appear on German campuses until after 1918. As the only constitutive student organizations in Germany prior to 1918 , fraternities and corps represented students at official celebrations and communicated student interests to university and state authorities. ${ }^{45}$

Similar to their American counterparts, German fraternities required and still require members to undergo traditional rites of passage. In the nineteenth and early twentieth centuries, fraternity pledges, called "foxes," underwent a trial membership period, lasting typically one to two semesters. At the end of the trial period, fraternity leaders tested pledges on their knowledge of the fraternity's traditions. A majority vote from the fraternity elevated pledges to full status as fraternity brothers. Wearing the fraternity colors meant that brothers could do nothing to betray fraternity honor and traditions. Fraternity regulations typically prohibited brothers from performing manual labor, socializing with Germany's less privileged elements or frequenting working class taverns or establishments of ill repute. ${ }^{46}$

\footnotetext{
${ }^{44}$ Steinberg, 11.

45 Paulgerhard Gladen, Gaudeamus igitur. Die studentischen Verbindungen einst und jetzt unter Mitarbeit von Ulrich Becker (Munich: Callwey, 1986), 7.

${ }^{46}$ Steinberg, 38-40.
} 
Upon graduation, fraternity brothers could claim the status of lifetime alumni. 47 Entitled to voluntary participation in fraternity life, alumni contributed to fraternity publications, lent their input to fraternity government and played prominent roles in student politics. Fraternity alumni supported active brothers financially and provided important connections to employment opportunities in Germany's public sector after graduation. ${ }^{48}$ In hard economic times, alumni contributions partially insulated fraternity members from the hardships that often threatened to pauperize "free" or unincorporated students. ${ }^{49}$

The German fraternity movement exerted its greatest influence at long-established universities located in smaller towns like Marburg, Tübingen, Freiburg, Halle, Jena, Würzburg, Heidelberg and Bonn. Many of these universities claimed a continuous historical existence extending into the High Middle Ages. These older universities proved to be less amenable to the curricular reforms demanded by students and interested civic leaders during the early twentieth century. By comparison, fraternities were less likely to impress students at the newer, typically more innovative urban universities. Founded in the twentieth century, universities in the cities of Frankfurt, Hamburg and

\footnotetext{
47 In German, Alte Herren, usually, "old gentlemen," but depending on context, probably more accurately rendered as "old boys."

48 Rösgen, 19.

49 Kater, 79.
} 
Cologne had, by the interwar years, established faculties in newer, applied fields like economics, sociology and political science. Along with established urban campuses in Leipzig and Berlin, these institutions attracted the sons of Germany's business and professional classes. The University of Munich represented the most notable exception to this rule. Located in the heart of a relatively liberal and culturally dynamic German city, the University of Munich hosted a powerful, and by the 1920s, unapologetically nationalist, fraternity movement. 50

\section{Fraternities, Student Culture and the Birth of German Nationalism}

At the beginning of the nineteenth century, influential Germans complained that German universities had become the repositories of cynicism, religious indifference and dubious morality. Unflattering contemporary accounts portrayed a university life dominated by unrestrained drinking, gluttonous feasts and frivolous duels. According to disapproving observers, students remained too preoccupied with entertaining their hedonist inclinations to tend to their religious obligations or their studies. ${ }^{51}$ When the university environment proved to be too small to contain their disorderly behavior, students descended on nearby towns to provoke further mayhem and brawl with the local

\footnotetext{
50 Steinberg, 45.

${ }^{51}$ Karl Hoeber, Handbuch für Mitglieder des Verbandes der kath. Studentenvereine Deutschlands (Cologne, 1921), 3-5.
} 
inhabitants. Citing contemporary sources, historian James Sheehan explains vividly: "After reading a few descriptions of student life in the eighteenth century, one has no difficulty understanding why many families were reluctant to send their sons to a university." 52

The traditionally carefree student life dominating German campuses changed when Napoleon's invasion of Central Europe sparked the birth of German nationalism. Energized by the nationalist exhortations of Romantic literati like Johann Gottlieb Fichte, German students mobilized against the Napoleonic occupation. As the years of Napoleon's occupation of Central Europe dragged on, student nationalism grew to be something more than a simple reaction against a foreign foe. Influenced reactively, constructively and ironically by many of the same ideals that had motivated the French Revolution, student nationalists on German campuses opposed both traditional feudal authority and institutionalized religion. In the German campus setting, nationalism meant change, progress and renewal.

The early nineteenth century modernizing measures of Prussian reformers like Karl Freiherr vom Stein, Wilhelm von Humboldt and Karl August von Hardenberg impressed particularly German students. As avowed political idealists, students on German campuses called for the

52 James Sheehan, German History 1770-1866 (Oxford: Clarendon Press, 1989), 137. 
replacement of Central Europe's fragmented and antiquated political fabric with a united German national state. They demanded further that the proposed national entity be structured along republican principles, meaning that it would have a written constitution, a guarantee of basic individual rights, and some form of deliberative parliament. Even if ruled by a king (as nationalists in Frankfurt in fact proposed in 1848), the German nation would be constituted as a Rechtstaat, where the rule of law would prevail.

After Napoleon's occupation, nationalist leaders argued that university training should prepare students to serve as active, committed leaders of a German national community. To that end, they believed that higher education should endow students with a stronger sense of high culture, as well as rhetorical and critical thinking skills. ${ }^{53}$ These skills would provide students with the foundation to exercise the free choice and individual responsibility necessary to participate actively and constructively in public life. The contemporary nationalist ethos also emphasized the importance of discipline and physical fitness in furthering both individual and collective development. As George Mosse has explained, some students also believed that they could distill

\footnotetext{
${ }^{53}$ Bildung: A broad, culturally engaged education in disciplines like history, literature, music and art. This educational ideal was offered in opposition to a university environment that had hitherto offered limited curricular opportunities in medieval fields like law, theology and medicine.
} 
German national values through a renewed, if agnostic (and antiClerical) engagement with Christian ethics. ${ }^{54}$ The priority attached to Christian character building survived and even thrived when later police repression of the German nationalist movement temporarily forced students out of public life.

German fraternities dominated the revelries that took place in the wake of the hated French dictator's defeat in 1815. At the 1817 Wartburg Festival, student fraternity members celebrated the recent expulsion of Napoleon's armies from Central Europe, burned allegedly "un-German"55 books and commemorated the three hundred year anniversary of Martin Luther's first public challenge to the Catholic Church, which they portrayed as a fundamentally formative moment in the development of the German national community.

In 1819 , the Carlsbad Decrees, promulgated by the legitimist servant of the House of Habsburg, Prince Clemens von Metternich,

54 George Mosse, The Crisis of German Ideology: Intellectual Origins of the Third Reich (New York: Grosset and Dunlap, 1964), 25, 159-164.

${ }^{55}$ Historians have provided remarkably conflicting accounts of this event. At least one contemporary print shows a seemingly endless, solemn procession of individuals proceeding to the fortress, but the actual number who attended the festivities apparently did not exceed 500 . George Mosse portrays the burning of books at the Wartburg as a deliberate, politically motivated act, prefiguring the chauvinist and belligerent tone of later German nationalism. Hajo Holborn provided a somewhat more ambiguous picture of student views on politics and nationalism. He believed that a much smaller group of students had burned bundles of paper inscribed with the names of allegedly reactionary authors (many of whom were German) as a symbolic prank to reenact Martin Luther's burning of the Papal Bull. 
targeted the German nationalist fraternities as hotbeds of subversive republican values and shut them down. Some three decades later, in 1848 , German nationalist students gained a temporary measure of revenge, when they played prominent roles in the nationalist revolutionary disturbances that swept through Central Europe and brought the Era of Metternich to an end. 56

\section{Fraternities and the Kaiserreich}

In the years after unification, the German Fraternity (DB), originally consolidated in 1818 , grew to be Germany's single largest national student fraternity organization. It maintained this honor through the Weimar years. The DB and other nationalist fraternities openly supported the government's early campaigns against Catholics. At the turn of the twentieth century, the DB promoted the more exclusionary, ethnic strain of nationalism that would become increasingly popular in Germany in the twentieth century. Germany's nationalist fraternities also endorsed the imperialism advocated by a newer, more aggressive generation of German nationalists. The leadership of the DB and other nationalist fraternities further

56 Rösgen, 8-12, 14. 
sympathized with the fairly short-lived anti-Semitic organizations on Germany's late nineteenth century political landscape. ${ }^{57}$

In the last decades of the nineteenth century, the nationalist student fraternities reached out to non-affiliated students. Named after a mountain where the medieval German Emperor Barbarossa purportedly slept, the Kyffhäuser Association of German Students' Unions (KSDSt), established in 1881, sought to combine fraternity and free students into a single nationwide organization. This highly visible organization funded its own press, propaganda and mass meetings. The tenor of this organization's ideology was distinctly anti-Semitic, taking its lead from contemporary German nationalists like Court Chaplain Adolf Stoecker and historian Heinrich von Treitschke. The KSDSt also encouraged contact with students in the Habsburg Empire, including Austrians and Sudeten Germans. ${ }^{58}$ After 1918, the KSDSt formed an important constituent in the German University Ring

57 Gerhard Schäfer, "Studentische Korporationen im Übergang zum deutschen Faschismus," 1999 Zeitschrift für Sozialgeschichte des 20. und 21. Jahrhunderts 3 (1988): 109-111.

58 Peter Stitz, Der CV 1918-1938. Der hochschulpolitische Weg des Cartellverbandes der Katholischen deutschen Studentenverbindungen (CV) vom Ende des. 1 Welktkrieges bis zur Vernichtung durch den Nationalsozialismus (Munich: Herausgegeben von der Gesellschaft für Studentengeschichte und studentisches Brauchtum, e.V., 1970), 17. Steinberg, 39. 
(DHR), 59 a powerful, nationalist student organization, which subsequent chapters will describe further.

As historian Michael Stephen Steinberg has explained, the Prussian martial ethos enjoyed a long tradition in the elite student corps. Through the late nineteenth century, this ethos became increasingly popular among Germany's middle class fraternity students. 60 Well into the twentieth century, feudal-style duels remained an integral element of university culture. Courts of Honor listened to complaints brought between students. Upon confirmation of a legitimate grievance, the code of honor entitled the offended party to demand a duel to exact satisfaction. Such confrontations rarely produced fatalities, but mensur fencing, a favored form of duel, very often inflicted visible facial scars. Members of the dueling fraternities recognized the scars as a sign of honor, bravery and virtue. While the duel itself remained technically illegal, the authorities rarely enforced the laws against it, even in the Weimar period. ${ }^{61}$

\section{The Catholic Fraternities}

The first embryonic Catholic student organizations, which formed in the early 1840s in the Rhineland university towns of Bonn and

\footnotetext{
59 Deutscher Hochschulring

60 Steinberg, 21.

61 Steinberg, 38-40.
} 
Münster, opposed the nationalist and dueling ethos that had characterized Germany's fraternity movements. As Karl Hoeber explained in his 1921 "Handbook for Members of the Association of German Catholic Student Fraternities," these early Catholic student associations tried to channel to German campuses the powerful wave of popular Catholicism generated by the Cologne Troubles of $1837.62 \mathrm{~A}$ historian of the Catholic fraternity movement, Peter Stitz, tells us that Catholic students sought to insulate themselves from the anti-religious sentiment that had allegedly infected Germany's non-Catholic youth. As Stitz also explains, Catholic students organized in the middle of the nineteenth century to combat the strong discrimination they had experienced on Germany's campuses. ${ }^{63}$

In addition to the fledgling associations on the Rhine, early Catholic student organizations included the Catholic Berlin Reading Society, formed in 1853. Seeking to promote the moral and spiritual education of its members, the Berlin Reading Society also served an academic and social purpose. Its founders believed that academic duty included as its fundamental imperative the effort to apply Christian religious ethics to scholarly knowledge and social virtue. In the middle and late nineteenth century, similar Catholic student organizations

${ }^{63}$ Stitz, 18. 
emerged throughout German speaking campuses. But lacking sufficient members or funds, or faced with hostile university authorities, most quickly dissolved. ${ }^{64}$

Germany's Catholic fraternities today recognize the Aenania Union at the University of Munich as the first truly fraternal Catholic university organization. Founded in 1851 by Franz Lorenz Gerbl, Aenania represented the sole organized Catholic presence among Munich's forty-six nationalist fraternities, corps and dueling associations. Aenania rejected the duel on religious grounds and required its members to wear fraternity colors. In 1856, Aenania consolidated with Winfridia, a Breslau Catholic student organization also opposed to the duel, to form the Cartel Union of Catholic German Student Fraternities, or CV.65 The CV soon after expanded to encompass the Catholic Berlin Reading Society, Arminia-Bonn, Innsbruck and the Catholic Academic Union at Münster. ${ }^{66}$

In 1865, the non-color wearing fraternities of the CV in Berlin, Bonn, Breslau, Münster and Würzburg formed their own Catholic organization, the Union of Catholic Student Fraternities of Germany, or

\footnotetext{
${ }^{64}$ Hoeber, 9.

${ }^{65}$ Cartellverband der katholischen deutschen Studentenverbindungen. Information concerning official incorporation dates and names of all student organizations and fraternities acquired from Hermann Haupt (editor), Handbuch für den Deutschen Burschenschaften (Gießen, 1926), 323-330, as reproduced in Rösgen, 92-99. 66 Gladen, 145.
} 
$\mathrm{KV} .{ }^{67}$ In spite of the permanent schism between the $\mathrm{CV}$ and the $\mathrm{KV}$, the two organizations continued to navigate mostly friendly relations well into the twentieth century. ${ }^{68}$ In the early post-World War I period, the $\mathrm{KV}$ expanded, as it absorbed an affiliated organization of southern German Catholic fraternities. ${ }^{69}$

Germany's third major nationwide Catholic fraternal organization, the Unitas Union, ${ }^{70}$ was founded in $1854 .{ }^{71}$ The first Unitas fraternities, appearing in Bonn, Tübingen and Würzburg, limited their membership to Catholic theology students. While insisting that formal religious training serve as the basis for fraternity activities, the early Unitas leadership also roundly criticized the allegedly unrestrained student lifestyles led by members of the elite corps and the nationalist fraternities. Unitas later opened up its membership to Catholic students from other disciplines in 1887.

The CV, KV and Unitas established their own rules for admitting new chapters and new members. ${ }^{72}$ Among the three major pre-1918

67 Verband der Katholischen Studentenvereine Deutschlands, in 1922, the KartellVerband der Katholischen Studentenvereine Deutchlands.

68 Gladen, 164. Rösgen, 16, 45. Hoeber, 22-23.

69 Hoeber, 62.

70 Verband der wissenschaftichen katholischen Studentenvereine Unitas.

71 Its first fraternity, Bonn Ruhrania (in existence since 1847), assumed the name Unitas in 1854, making it technically the oldest of the three fraternal organizations. Rösgen dates the official founding to the absorption of Unitas Tübingen in December 1855. The union held its first General Assembly in 1860.

${ }^{72}$ Hoeber, 20-21. 
fraternity organizations, however, Unitas alone insisted on the unitary principle, which centralized its leadership and allowed for less local autonomy. ${ }^{73}$ Among the three, Unitas was known to take much more decisive political stands. It also stood the closest to contemporary Catholic social thought. ${ }^{74}$ Through the late nineteenth and early twentieth centuries, Unitas alumni like Frantz Hitze and Joseph Mausbach made prominent contributions to Catholic social causes. As Hubert Mockenhaupt's remarkably favorable biographical sketch tells us, Hitze stood prominently on Germany's Catholic landscape for nearly forty years. ${ }^{75}$ The leading Catholic supporter of Bismarck's social legislation, Hitze later served as the first Chair for Christian Social Doctrine at Münster. Both Hitze and Mausbach contributed to the Weimar Constitution after World War I. Unitas later dedicated the June 1930 edition of its monthly newspaper to Mausbach's prolific contributions to the Catholic community. ${ }^{76}$ Unitas also contributed prominent alumni to Germany's Catholic hierarchy, most notably,

\footnotetext{
73 Rösgen, 57.

74 Rösgen, 16.

${ }^{75}$ Hubert Mockenhaupt, "Franz Hitze (1851-1921)," in Zeitgeschichte in Lebensbildern: Aus dem deutschen Katholizismus des. 20 Jahrhunderts, herausgegeben von Rudolf Morsey (Mainz: Matthias-Grünewald-Verlag, 1973), 53-64.

76 Untitled, Unitas 70 (June 1930).
} 
Cardinal Adolf Bertram, elevated to the Archbishopric of Breslau immediately prior to the outbreak of World War I. ${ }^{77}$

In their early years of existence, Germany's Catholic promoted their fraternities as student focal points, constituted on the principles of religion, scholarship and student welfare. Catholic students believed that their fraternities should serve as conduits for greater spiritual unity, personal growth and the exchange of experience and advice. At the most basic level, the Catholic fraternities emphasized the importance of religious principles in the building of moral character. The early leadership of the CV criticized openly Germany's secularizing society. Fraternity leaders likewise sought to defend the Catholic Church and its worshippers from invasive state authorities and their anti-clerical allies.

In 1861 , Georg von Hertling began to attend Aenania activities in Munich. The future chancellor of Germany reported approvingly that Catholic students were expressing through fraternity membership their desire to restrain the traditional excesses of student life. Hertling also believed that Catholic fraternities would "counteract the widespread misuse of academic freedom," a thinly veiled criticism of liberal scholarship. He believed that their fraternities should similarly remind

77 "Dr. Adolf Kardinal Bertram," Unitas 60 (January 1920): 61-66. 
Catholics of the importance of their religious convictions. In 1866, Hertling helped to establish an affiliated CV fraternity in Würzburg. ${ }^{78}$ For Germany's Catholics, the university years represented a potentially dangerous period of independence from the restraining influences of Church, confessional school and the authoritarian household. Observing the early activities of the CV, leaders in the German Catholic hierarchy and in influential intellectual circles were pleased that Catholic fraternity members were not abusing their newfound freedom. In their early pronouncements, Catholic fraternity members signaled their intention to respect important religious boundaries, laws and morals. Catholic students saw their fraternities as shelters, as they confronted, perhaps for the first time in their lives, the countervailing ideals of liberal scholarship and modern science. Influential Catholics in the hierarchy, in intellectual circles and, later, in the Catholic Center Party, believed that the new fraternities must similarly dissuade young Catholics from elevating their own opinions above those of the established ecclesiastical authorities.

In 1921, Karl Hoeber would argue that Catholic fraternity students, simply by virtue of their Catholicism, could not be accused of being any less patriotic to the German fatherland. Nevertheless,

${ }^{78}$ Windell, 38. 
through the nineteenth century and well into the twentieth, Germany's Catholic leadership, in the Church hierarchy and elsewhere, insisted that only exclusively Catholic organizations like the fraternities should serve as proper sites for young Catholic students to bond socially and develop their Catholic confessional identities. ${ }^{79}$

\section{Catholic Fraternities in the Years before World War I}

After the Wars for German Unification (1864-1871) concluded, Catholic fraternities continued to add new members and new local chapters. In light of the public hostility that Catholics encountered on Germany's campuses during the Kulturkampf, the expansion of Catholic fraternity life after 1871 surprised many observers. Hoeber tells us that Catholic fraternity chapters in Leipzig and Königsberg only with considerable difficulty convinced university authorities to confirm their statutes. Questioning the national loyalty of Germany's Catholic students, critics reserved their sharpest attacks for the $\mathrm{CV}$, the largest of the Catholic fraternity organizations and the only major pre-World War I Catholic color-wearing organization. ${ }^{80}$

During the difficult years of the Kulturkampf, Pius IX and Leo XIII both supported Germany's Catholic fraternities. Catholic observers in Germany then and later took pride in the fact that Catholic fraternity

\footnotetext{
${ }^{79}$ Hoeber, $10-12$.
}

80 Stitz, 18. 
representatives had found audience with the Pontiff. At the end of the nineteenth century, the German bishops endorsed the Catholic fraternity movement as a phalanx of spiritually committed, educated and serious members of the Catholic community. The Wittelsbach ruling dynasty in Bavaria also lent its support to the movement. 81

Although they maintained an official stance of political neutrality, Catholic fraternities, through their growing alumni networks, maintained strong contacts with the Catholic Center Party. The relationship between Catholic fraternities and the Center Party lasted through the Weimar period. Prominent Center Party politicians included KV alumnus Karl Trimborn and CV alumnus Felix Porsch. In the last years of World War I and, then, during the interwar period, the CV could claim four alumni who had served as German Chancellors, including Hertling, Konstantin Fehrenbach, Wilhelm Cuno (politically unaffiliated) and Heinrich Brüning (also an honorary member of a KV chapter). The KV too could claim a Chancellor, Wilhelm Marx. One of the most well respected politicians on interwar Germany's entire political landscape, Marx ran a surprisingly competitive second to war hero Paul von Hindenburg in Germany's 1924 presidential election. Historian Hans-Jürgen Rösgen has speculated that participation in

${ }^{81}$ Hoeber, 27-30. 
their fraternities afforded young Catholics the opportunity to practice their rhetorical skills and, at the same time, to appreciate their responsibilities as future leaders of Germany's Catholic community. Informal contacts with established Catholic Center politicians similarly gave fraternity alumni the inside track to positions of prominence in the Center Party after graduation. ${ }^{82}$

Catholic fraternities provided inviting targets for nationalist students during the frequent periods of broader hostility against Germany's Catholic population, however. Since approximately 1890, ongoing conflicts between the established liberal professoriate and Catholic scholars became known collectively as the Academic Kulturkampf. The Protestant League in part was responsible for initiating these hostilities. Martin Spahn's nomination struggle to serve as the History Chair at Strasbourg in 1902 similarly provoked a broader academic reaction against Catholics. ${ }^{83}$

Confessional tensions on Germany's campuses reached a crescendo in the town of Jena on Ash Wednesday, 1904, when dueling and nationalist students heckled members from the newly founded CV fraternity chapter Sugambria as they proceeded through the public marketplace. The dueling students later broke into the Sugambria pub,

82 Rösgen, 77-79.

${ }^{83}$ Cary, 31. 
destroyed the fraternity drinking table and assaulted its female proprietor. In the aftermath, critics accused the Catholic fraternities of posing a national danger and petitioned the Jena administration to dissolve Sugambria. Writing over a decade later, Hoeber used the words "fanaticism" and "hate" to describe the attitude of the dueling and nationalist students against the Catholic fraternities. In response to the tensions, an ad hoc Senate meeting at Jena decided to prohibit color-wearing confessional organizations altogether. ${ }^{84}$

Physical confrontations between nationalists and Catholic fraternities (particularly the visible color-wearing CV) soon spread to Germany's other campuses and spilled over into Austria. 85 Some three months after the confrontation at Jena, on June 24,1904 , a student assembly in Hanover demanded that the rector and the academic senate suspend the existing Catholic fraternities and prohibit the formation of any new ones. At Hanover and elsewhere, nationalist fraternity students charged that the Catholic fraternities were serving as bastions of political Catholicism and Papal Ultramontanism. Over the objections of Catholic fraternity representatives, the administration

\footnotetext{
${ }^{84}$ Hoeber, 46-47.
}

85 Stitz, 18. 
in Hanover passed the proposals. University administrations entertained similar proposals against Catholic fraternities elsewhere. ${ }^{86}$

In 1904, at the apex of hostilities against the Catholic fraternities, Catholic fraternity members constituted approximately one-fifth of all German fraternity students. Among Germany's 784 fraternities, 98 were Catholic, representing a total of approximately 4,000 active members. Their growing numerical strength may have provided the saving grace for Catholics during this highly charged period. Well aware of the confessional tensions affecting many German universities, academic authorities expressed their hesitance to endorse an offensive against such a broad segment of the student body. Although the Union of German Universities (VDH) ${ }^{87}$ formed in 1905 to coordinate a nationwide campaign to dissolve the Catholic fraternities, university administrations reacted to its demands with caution. The Technical College at Karlsruhe, for instance, notably rejected a proposal to restrict or ban its Catholic fraternities. Seeking to calm the potentially destructive inter-confessional passions sweeping through Germany's universities, Kaiser Wilhelm II responded to a routine message of praise from a nationalist fraternity by reminding its members to respect

\footnotetext{
86 Hoeber, 47.

87 Verband Deutscher Hochschulen (VDH)
} 
religious freedom and to tolerate the confessional convictions of other students. ${ }^{88}$

As the KV convened in Freiburg in 1905 for its Thirty-Eighth General Assembly, its leadership acknowledged the hostility that its chapters had faced on Germany's campuses in the previous months. It similarly conceded that Germany's nationalist students had targeted Catholic fraternities, primarily because Catholics had organized around their faith as their first and fundamental allegiance. In its official response produced at the assembly, the KV membership signaled no intention to apologize. The $\mathrm{KV}$ also rejected the accusation that Catholic fraternities were collaborating with the Center Party, even if some of its alumni did play active political roles. Finally, the KV responded to the accusations of national disloyalty with bitter indignation: "In love for the fatherland, we feel as one with the entire German student body." 89

Judging enrollment numbers as a barometer of support, it appears that German nationalists had failed to intimidate Catholic students away from their fraternities. As Hoeber observed, "On the contrary, new chapters at that time were being added to Catholic fraternities at numerous universities." By 1908, the anti-Catholic VDH

88 Hoeber, 51-52.

${ }^{89}$ Hoeber, 53-55. 
dissolved, as tensions between Catholics and non-Catholics on Germany's campuses subsided. 90

The troubles of 1904 and 1905 motivated the Catholic fraternities to expand their membership rolls. Fraternity leaders also renewed their efforts to promote Catholic unity and cooperation. In 1908, women enrolled in many German universities for the first time. At the Universities of Bonn, Munich and elsewhere, Catholic women's leagues sought to establish cooperative ties with their male counterparts. ${ }^{91}$ In 1913, the formation of the Union of Catholic Female Student Organizations of Germany ${ }^{92}$ signified a notable outcome of these activities. This organization maintained its own publishing organ through the Weimar years. As part of their expansion and consolidation activities, Catholic students in 1912 also established a union for unincorporated Catholics, the national Union for Free Associations of Catholic Students. ${ }^{93}$

In the immediate years prior to World War I, the Catholic fraternities took more visible steps to prove their loyalty to the German nation. The $\mathrm{CV}$, for instance, sent representatives from numerous chapters to the October 18, 1913 inaugural celebrations at the

90 Hoeber, 53-55.

91 Hoeber, 55, 57-61.

92 Verband der katholischen Studentinen Vereine Deutschlands

93 Verband der Freien Vereinigungen katholischer Studenten 
Memorial for the Battle of Nations at Leipzig. ${ }^{94}$ At the outbreak of World War I, less than a year later, students on Germany's campuses embraced Kaiser Wilhelm's call for a nationwide "civil peace." The rush to serve the national cause helped heal, at least temporarily, the profound confessional scars running through Germany's campus environment. ${ }^{95}$

As will be explained in the next chapter, Germany's Catholic students saw World War I as a moment of great opportunity to prove their loyalty to the national cause. In the last years of World War I, Catholic fraternities had considerable reason to take pride, as Germany's wartime leadership elevated one of their own, a senior, founding member of the movement, Hertling, to the German Chancellorship. They hailed the decision of Germany's conservative Protestant monarchy to select a political Catholic to serve the German Empire at its darkest hour. For fraternity students in particular, Hertling's elevation represented a vindicating moment for Germany's Catholics and, especially, their fraternities. 96

\footnotetext{
94 Stitz, 19.

95 Gladen, 39.

96 Hoeber, 59-60.
} 


\section{Chapter 2}

\section{Catholic Fraternities at War}

Our family homes were located just minutes apart. We attended the same schools, went to prep school together, were together at the same university, belonged to the same Unitas Frisia fraternity and pursued the same high goal, the sacerdotium Jesu Christi, only with one difference: he was always a year behind me. Then the war arrived that tore us apart. And now, after my dear friend has rested in the ground of Flanders for two years, I write his obituary. obituary written for Lieutenant Joseph Baule, appearing in Unitas, May $1920^{1}$

As historian Peter Fritzsche explains, the efforts of the imperial government in the decades after 1871 to generate enthusiasm for the new Reich left a shallow impression on the German population. Many Germans before 1914 continued to orient their compasses to regional capitals, many of which had once served as the focal points for independent and culturally distinctive entities. German unification left both the Catholic and working class elements of the German population on the outside looking in. Nationalism did make stronger inroads among educated professionals, government civil servants and entrepreneurs. But, demographically, these were scarcely adequate to transform the ideology of German nationalism into a true mass movement. Before 1914 observers were in the habit of belittling the

1 "Leutnant d.R. cand. theol. Joseph Baule," Unitas 60 (May 1920): 107. 
official nationalism offered by Germany's ruling elites as "hurrah patriotism."2

In World War I, German nationalism finally came of age. The war energized the collective affinities of the German nation like never before, leading the Kaiser to proclaim famously on August 1, 1914: "I no longer recognize parties and confessions.... today we are all German brothers and only German brothers." 3 The subsequent four years saw over two million Germans die in the meat grinder of battle. ${ }^{4}$ Amazingly, the war did nothing to discouraged German nationalists. After the war's conclusion in November 1918, nationalists celebrated the experience as a defining moment in Germany's emergence as a true national community. 5

Most historians now agree that, in the process of doing so, Germany's nationalists selectively falsified public memories of the war. ${ }^{6}$ Most famously, polemicists and politicians who claimed to embody the national cause argued that Germany's new republican government had sold out the nation at the armistice of 1918 and at the Versailles peace settlement. This settlement, reached in the summer of the following

\footnotetext{
2 Peter Fritzsche, Germans into Nazis (Cambridge and London: Harvard University Press, 1998), 16-23.

${ }^{3}$ As quoted in Fritzsche, 17.

4 and hungry Germans at home straining turnips to make coffee

${ }^{5}$ George L. Mosse, Fallen Soldiers: Reshaping the Memory of the World Wars (Oxford and New York: Oxford University Press, 1990), 106.

${ }^{6}$ See Peter Fritzsche, Richard Bessel and George Mosse, among others.
} 
year, had seemingly confirmed Germany's decisive defeat in November 1918. But some prominent Germans, many of whom were actually in a good position to know otherwise (including Hindenburg, the army's chief commander), told a very different story. The German Army, so the now infamous "stab-in-the-back" lie went, had left the battlefield in November bloodied but unbowed. Ultimately, traitors at home, not the overwhelming material superiority of the Allies, had undermined its mission. As the story went, these very same traitors were in charge of Germany's republican government after 1918. For Germany's nationalists, mythologized memories of the war would provide ideal rhetorical ammunition in their efforts to undermine the legitimacy of Germany's new republic.

According to the redoubtable account of historian George Mosse, the outbreak of war in August 1914 liberated Germany's youthful volunteers from the unremarkable routine of daily life. The war offered to these idealistic volunteers the collective camaraderie of the trench. The war experience also validated the ideal of "militant masculinity," which many had inherited from the German youth movement. Rather than dwell on the horror of the war or its inglorious conclusion, survivors from the August 1914 volunteer cohort chose to focus on the positive side of the war experience. Their efforts after 1918 to recast the 
war as a fundamentally regenerative experience impressed Germany's nationalists, most notably, Adolf Hitler's National Socialists. ${ }^{7}$

Most soldiers who served in the German armed forces through the duration of World War I, admittedly, were not volunteers.

Germany's soldiers typically did not hail from the youth or the students. Most soldiers who fought between 1914 and 1918 were reservists of more advanced years, who had never studied at a university. War duty forced many, if not most of Germany's soldiers to leave families and jobs behind.

Nonetheless, the youthful and idealist volunteers of August 1914 dominated the public war narratives. It was precisely this cohort, as Mosse explained, that found appeal in narratives from war veteran literati like Ernst Jünger, who sought to portray the war as a positive experience, as a realization of a higher ideal, as the opportunity to transcend the limitations of death itself. 8 Many of the surviving

\footnotetext{
7 Mosse, Fallen Soldiers..., 25-27, 60.

8 Storm of Steel (Stahlgewittern) is typically portrayed by most knowledgeable historians of the period as a stylized, romanticized account of the front experience. For instance, Jeffrey Herf has called the 1920 work a "spectacularly aestheticized version of life in the trenches." Jeffrey Herf, Reactionary Modernism: Technology, culture and politics in Weimar and the Third Reich (Cambridge: Cambridge University Press, 1984), 72. My own reading yielded a more subtle and complicated picture. As early as the first chapter, Jünger admits to his encounter with shellshock and notes, tellingly, "The effect upon the dark regions that lie beneath the consciousness was so deep that at the least interruption of the usual course Death started up with warning hand, or as he does in those clocks where he appears above the dial at every hour with sand-glass and scythe. It was a sensation over which habit could not prevail, since the instinct of self-preservation remains always the same. The notion that a
} 
volunteers from August 1914 would enroll in Germany's universities after 1918 and play prominent roles in public student life. ${ }^{9}$

In Mosse's words, memories of the war would provide nationalist opponents of Germany's new republic with their most effective "myths and symbols." Not only would opponents of German's republic deploy the memory of the war as a powerful propaganda device to mobilize support and win votes. More broadly, mythologizing the war allowed the anti-republican elements to "brutalize" German politics, as Mosse explained, making it acceptable for the National Socialist Party (and, later, the National Socialist regime) to target enemies with violent hostility and to "numb men and women" to "human cruelty and the loss of life." 10

The National Socialist movement advertised itself as the legitimate heir of the war experience. Its leader was a decorated war veteran, Adolf Hitler. Hitler's party organized itself along military models,

soldier becomes hardier and bolder as war proceeds is mistaken. What he gains in the science of attacking his enemy he loses in strength of nerve. The only dam against this loss is a sense of honor so resolute that few attain it. For this reason I consider that troops composed of boys of twenty, under experienced leadership, are the most formidable." Ernst Jünger, The Storm of Steel (New York,: Howard Fertig, first paperback printing, 1996), 4.

${ }^{9}$ Approximately ninety percent of Germany's students in the immediate years after the war were returning war veterans. See Geoffrey Giles, Students and National Socialism in Germany (Princeton: Princeton University Press, 1985), 16. Konrad H. Jarausch, Deutsche Studenten: 1800-1970 (Frankfurt am Main: Suhrkamp Taschen Verlag, 1989), 118, 122.

10 Mosse, Fallen Soldiers...,159. 
deployed military symbols to powerful visual effect and, in its propaganda, offered a state of permanent war as the vehicle that would harden and hone the German national community in its life and death struggle against national enemies.

For opponents of Germany's republic, memorializing the Great War reflected nothing less than a struggle for ownership over Germany's national identity. These anti-republican forces would denounce as cowards those who had condemned World War I as a senseless waste of human life. They would likewise discredit those who had portrayed realistically the last months of the war, when German soldiers stood on their own, practically starving, unable to fend off numerically and materially superior opponents. More ominously, anti-republican propagandists would brand as traitors to the German national cause anyone who resisted their mythologized interpretation of the war.

\section{Catholic Memories of the War Experience}

St. Thomas Aquinas, the medieval voice of Catholic authority on politics, is still revered by the Catholic Church as its Angelic Doctor. As will become clear in subsequent chapters, St. Thomas continued to render a powerful influence on educated Catholics during the early twentieth century. On the subject of war, St. Thomas had this to say: (1) a ruler is obligated to protect the people from a foreign enemy; (2) a 
ruler may, for the purposes of war, demand "the levying of a multitude of men" (3) a war, including an offensive war, is justified when its purpose is to "lay the foundations for a better and lasting peace." 11

With justification the historical record has looked with disfavor upon the decision of Germany's leadership to go to war in August of 1914. Nonetheless, to Germany's Catholics, all three of the conditions (arguably at least) set forth by St. Thomas were in place during the war's outbreak in August 1914. Therefore, even if their reasoning proved to be problematic, most Catholics believed that disloyalty to Germany's wartime cause was not an option. As Berlin Professor A. Timpe, an alumnus of the Göttingen chapter of Unitas later explained, insofar as war was concerned, the Fourth Commandment to obey one's mother and father took precedence over the Fifth Commandment's prohibition against murder. ${ }^{12}$ Wilhelm Winkler, a contributor to Academia, in 1925 would affirm similarly:

The nation has a right to exist, and it is a moral obligation to defend it. He who defends his people in the spirit of Christianity, is simultaneously defending humanity. ${ }^{13}$

\footnotetext{
11 From Dino Bigongiari's introduction to The Political Ideas of St. Thomas Aquinas (New York: The Free Press, original copyright 1953, first paperback edition 1997 used here), xvii.

12 Professor Dr. A Timpe, Berlin (A.H. Unitas-Göttingen), "Vaterlandsliebe und Pazifismus" Unitas 66, Nr. 2 (Nov. 1925): 25-27.

13 Dr. Wilhelm Winkler, Ae, "Eine Erwiderung..." Academia 38, \#3 (July 15, 1925): 6263.
} 
As Pope Benedict XV recognized, in Germany, France, Italy and Russian Poland, this way of thinking achieved an evident absurdity. From 1914 to 1918 , all along the western and eastern fronts, through the Brenner Pass and down the Trentino Alto Adige, Catholics were killing Catholics.

Either because the Church's teachings told them to do so, or else, because they were genuinely motivated by the patriotic cause, the vast majority of Catholic fraternity students joined their nationalist cohorts and hurried to the German imperial flag in August 1914. The war exacted a heavy death toll on Germany's Catholic fraternities. The CV, Germany's largest Catholic fraternity, had 12,454 active student members and alumni enrolled within its ranks at the outbreak of the war. Among these, over half, 7,237 by official accounts, participated in the war. 1,286 never returned. ${ }^{14}$ The KV and Unitas fraternities experienced comparable casualty rates.

The memory of the war experience dominated student Catholic discussions through the entire duration of the Weimar Republic. All three nationwide Catholic fraternity publications, the KV's Academic Monthly Pages, the CV's Academia and the Unitas fraternity's Unitas included in their front pages extensive obituaries dedicated to those

\footnotetext{
14 Peter Stitz, Der CV 1918-1938. Der hochschulpolitische Weg des Cartellverbandes der Katholischen deutschen Studentenverbindungen (CV) vom Ende des 1. Weltkrieges bis zur Vernichtung durch den Nationalsozialismus (Munich: Herausgegeben von der Gesellschaft für Studentengeschichte und studentisches Brauchtum, e.V., 1970), 28.
} 
who had fallen in combat. In the immediate months after November of 1918, Unitas headlined its publication with the stark title "Our Dead." Even more dramatically, the front cover of Academia urged its readers: "Do not forget the faithful dead!"

The fraternity members who penned these emotional obituaries had been closely acquainted with the fallen. The obituaries described in detail how fallen fraternity brothers had lived before volunteering for war service. They also lauded the heroic conduct of fallen brothers who had served on the front. The obituaries nearly always lauded the values that fallen brothers had embodied in relations with family, fraternity, army and Church. Although their writing could seem at times formulaic and restricted to rather predictable narrative paradigms, the authors of these obituaries tell us a great deal about how Catholic war veterans from the fraternities defined virtue and heroism. They also reveal how these war veterans believed that their Catholicism had informed their service to Germany's wartime cause.

\section{The Catholic Soldier}

Many Catholic soldiers had already undergone complex, intriguing and sometimes traumatic life experiences before the outbreak of world war in August 1914. Some had barely reached the age of majority, but many others had left careers, wives and children behind. 
Most lived in deeply layered social networks and had maintained strong connections with family, childhood friends, fellow students and fraternity brothers. Nearly all veteran survivors from the Catholic fraternities described their fallen brothers as deeply religious. Survivors also emphasized the strong connections between their fallen brothers and the Catholic Church and community. As the obituaries typically explained, the fallen had harbored optimistic ambitions that the war had annihilated permanently.

A contributor to the Unitas fraternity obituaries described Franz Laarmann as "my dear fraternity brother, compatriot and friend from youth." 15 In 1913, Laarmann had received the degree of Candidate of Philosophy after studying history and philology. Laarmann volunteered for the national cause in the autumn of 1914, in "full awareness of what the fatherland demanded of him." He served on both the eastern and western fronts and earned the Iron Cross after participating in battle in Flanders in 1917. According to his fraternity brother, Laarmann "froze in the cruel cold of Russia, lay in Flemish mud and was wounded three times." In his personal letters, Laarmann had expressed his admiration for his older brother and his love for his parents. Like his older brother,

\footnotetext{
15 "Mein Leibbursch, Landsmann und Jugendfreund" Leibbursch: a term of high endearment. Leib literally means body. Bursch translates directly to lad, but is here equivalent to fraternity brother.
} 
Laarmann hoped to study for the priesthood when the war was over. An English gas attack ended Laarmann's dreams permanently on the night of March 19, 1918. He died in a field hospital eleven days later. ${ }^{16}$ Born on January 1, 1889 to a civil servant in Augsburg, August Aichinger studied philology at Munich and seemed destined for a career in service of the state. Fascinated by religious and philosophical questions, Aichinger also took an interest in world politics and literature. According to his fraternity brother, Aichinger was a dedicated soldier, having fought on the Somme in 1916. The German army promoted Aichinger to officer status and awarded him the Iron Cross, First Class. A bullet in the chest seriously wounded Aichinger in August 1916. Like many of the soldiers described in the Catholic obituaries, Aichinger returned to the front after suffering wounds on multiple occasions. On May 22, 1918, Aichinger found himself again in a military hospital, this time, seriously wounded in the leg and the back. Unfortunately, this time, "the power of death was stronger than his will." Aichinger spent his final days essentially unconscious, but, as the obituary explains, he still acknowledged the presence of his parents, who stayed by his side until his death. ${ }^{17}$

\footnotetext{
16 Hans Schas, “Dr. Franz Laarmann, cand. phil," Unitas 58 (August 1918): 199-200.

17 Kaplan Abmahr, Ae, "Lehramtspraktikant August Aichinger, Ae," Academia 31 (November 15, 1918): 149-150.
} 
In the Catholic fraternity obituaries, surviving veterans stressed that Catholic religious virtue had defined the lives of their fallen brothers before the war and had informed strongly their actions while they served on the front. The writer of Franz Laarmann's obituary explained that Laarmann had been "born to pious parents and raised in the fear of God." He also verified the importance of Catholicism at the end of Laarmann's life, noting that the fallen young soldier had been able, just before his death, to take temporary leave to his home town where he participated in the holy sacraments. ${ }^{18}$

According to his colleagues, Joseph Hölling of the Sigfridia Bonn chapter of Unitas had gathered to the flag driven by youthful fire and a deep felt awareness of duty. Originating from a religious family, Hölling demonstrated a "deeply anchored" piety both before and during the war. As his fraternity brother explained, "he was an Israelite in whom nothing was false." This is a reference to John $1: 47$, specifically, Jesus' description of Nathanial, whom he first saw under a fig tree. ${ }^{19}$ The

\footnotetext{
18 Schas, "Dr. Franz Laarmann...," 199-200.

19 In German as "ein rechter Israeliter, in welchem kein Falsch ist." This passage has more commonly been rendered in English as "a true Israelite, in whom there is no guile," or in the Catholic New American Bible (1969): "Here is a true Israelite. There is no duplicity in him." In the prophetic literature of the Old Testament, specifically, Micah 4:4 and Zechariah, 3:10, a fig tree is described as a sign of "messianic peace." See Catholic New American Bible (1969), note 1, 48 (page 1191).
} 
writer of his obituary continued: "No work was too hard" for Hölling "if he could help others." 20

According to his obituary, Ludwig Hastler had lived a simple and unpretentious life. Born in 1896 in Würzburg, Hastler volunteered to the flag in April 1915. "Serious and quiet," Hastler stood stoically undeterred by the dangers of war. But aside from serving the fatherland, his priorities were first and foremost "honoring God" and "caring for the people." According to his obituary, Hastler had always leaned on his religious faith as a "protecting angel." 21

Hastler's obituary ended with some apparent bitterness. That Hastler died a hero's death did not mitigate the waste of a promising life. As the writer of his obituary explained: "His was a life full of promise: the grenade annihilated everything." An obituary appearing in the same publication betrayed similar sadness over the death of Otto Faesche, a student of law in Breslau in 1908, and starting in 1913, medicine. Faesche had served actively to expand his fraternity, helping out with the founding of the fraternity pub on Albrecht Street. "All too

\footnotetext{
20 Theol. H. Griese, “Joseph Holling, stud. theol.," Unitas 59 (July 1919): 167.

21 Von seinem Bruder Kaplan Jos. Hastler G.W., "Ludwig Hastler GW," Academia 31 (December 15, 1918): 176.
} 
early, Otto Faesche left his parents, his siblings, friends and fraternal brothers. Sleep, true fraternal brother, in your hero's honor."22

Contributors to the obituaries appearing in Catholic fraternity publications announced that Germany's Catholics had experienced staggering losses in the war. They also searched, sometimes painfully, for the words to describe the loss embodied by a single personality in a war that had annihilated millions. Wilhelm Schwermer, "an unflappable Westphalian" and a member of the Unitas Winfridia chapter in Münster, volunteered for duty in the first weeks of the war. Schwermer served for nearly four years in the trenches of Northern France. On May 4, 1918, a grenade ended Schwermer's life. The author of the obituary was quick to point out that Schwermer had earned the respect of his comrades and troops. He then tried to come to terms with the devastation that his loss would mean for family and immediate friends:

Mother and bride and only sister would cry for their beloved hero. As for us, who are left behind, from our little flock, twenty-three never returned. We ourselves know what loss we have suffered. The picture of Schwermer will be with us through life: his faith to Church and people, his belief in ideals... his love for learning and friendship. ${ }^{23}$

\footnotetext{
22 Dr. Paul Schmidt, Studienassessor, "iur. Otto Faesche, Sal," Academia 31 (December 15, 1918): 176.

23 J. Vincke, "Dr. Wilhelm Schwermer," Unitas 59 (August 1919): 224-225.
} 
Otto Lühr's obituary writer claimed after his death on May 27, 1918: "I lost a true friend, a shining and capable fraternity brother." His fraternity brother sadly reported that Lühr "was never able to fulfill his hope to come back to us after a happy ending to the war." He concluded: "He will remain in our memory forever as a high thinking man, true to his obligations, a faithful, dependable friend and a good, dear fraternity brother." 24

Born in the Saar, Andreas Mertens lost his father at the age of two. According to his obituary, Mertens's mother had to make "every sacrifice to give him a proper upbringing." From 1900 to 1903, Mertens studied to be a priest at Trier, but then "heard another calling" 25 and transferred to Bonn, where he studied mathematics and the natural sciences. Fraternity brothers in Bonn described Mertens as a "spirited brother of Unitas," active in fraternity life. Mertens helped to organize the fraternity's 50 year anniversary celebrations and, later, contributed to the construction of the fraternity house. Originally attached to a medical detail, Mertens transferred to the regular army in October 1916. A deadly influenza virus struck Mertens down on the western front. Faithful to the end, Mertens resigned himself to a "pious death." Immediately prior to his passing, Mertens was able to fulfill his final

24 Dobbek, "Otto Lühr," Akademischer Monatsblätter (15 October 1919): 127.

25 the German words for "calling," "vocation" and "occupation" are identical 
wish of receiving the holy sacraments. ${ }^{26}$ His fiancée, a Red Cross sister, remained by Mertens's side until the virus finally claimed him on the 28th of July 1917.27

A childhood friend and fraternity brother described Joseph Baule as a serious student and a brother of Unitas with "heart and soul, noble, pure, and spiritual." A member of the Unitas Frisia fraternity, Baule studied theology at the University of Münster for six semesters. Baule's fraternity brother described his fallen colleague as a "true Christian" and "deeply religious." He also described Baule as one of the fraternity's most active and dedicated members:

At its functions, it its meetings, at its rambles, he was always there. He was then so happy in his social circles, always cheerful, captivating, self-sacrificing and devoted. How often he made us happy with his beautiful singing, how often he elevated us with the piano...28

A fraternity brother similarly lauded Bruno Rossmann for his dedication to family and fraternity. "Full of hope, a good son, brother and enthusiastic member" of his fraternity chapter, Rossmann spent his "vacations happily communing with his fraternal brothers." His

\footnotetext{
${ }^{26}$ The reference here is not entirely clear, but would typically mean making confession, taking communion and, if on his death bed, receiving the last rites. 27 "Oberlehrer Andreas Mertens," Unitas 60 (December 1919): 41.

28 "Leutnant d.R. cand. theol. Joseph Baule," Unitas 60 (May 1920): 107.
} 
obituary concluded: "In prayer for the care of his soul, we remember him."29

Contributors to all fourteen obituaries appearing in Academia on March 25, 1920 hailed their fallen brothers as dedicated members of the CV. Karl Kellner had been a Doctor of Medicine before the war. Displayed in a photograph next to his obituary wearing the basic field grey military uniform of the German army, Kellner had the "ideals of the CV strongly anchored in his heart and wore the colors" of his fraternity chapter "with sublime enthusiasm and happy pride." 30 Joseph Küpper was 37 years old and the married father of three children when he died of a respiratory infection at a military hospital in June 1918. A fraternity colleague described Küpper as an ...enthusiastic friend of the fatherland, a convinced brother of the CV and a true son of his holy Church.... His family has lost much. He gave to them all his love and quiet devotion. The CV has also lost. For its ideals, he remained, at all times, faithful and resolute. And we, his friends have lost... ${ }^{31}$

Michael Messerschmidt's obituary included a photograph of the nineteen year old pledge wearing the colorful sash, cap and neck-tight jacket of his fraternity alma mater. Messerschmidt fell on November 12, 1918 , as "a true Catholic."

\footnotetext{
29 Von seinem Leibburschen, "Bruno Rossmann," Academia 32 (25 March 1920): 346.

30 Franz Voß, "Dr. med. Karl Kellner PG,” Academia 32 (25 March 1920): 340.

${ }^{31}$ Gerichtsreferandar, "Joseph Küpper," Academia 32 (25 March 1920): 342.
} 
His fraternity has lost much on this day, a sunny person, for whom the rose-white-light blue fraternity symbol represented a genuine true, hardworking friendship, a fraternity brother, for whom the motto et constanter became a life's creed, faithful to God, his fatherland and his friends. 32

Well over a year after the war had concluded, the obituaries had lost little of the sorrow, grief and pride of the early months after the armistice. Paul Kalkum had been reared in modest origins, literally, by "little people" as the writer of his obituary explained affectionately. After finishing his basic general education ${ }^{33}$ at 14 , Kalkum worked in the business world for three years, before finally making the opportunity to study at a university. "I tell you this," as the writer awkwardly clarified, at a time when the vast majority of Germany's university students had hailed from the elite college preparatory schools, because "Kalkum himself was happy to talk about it." At Verdun, Kalkum met the "hero's death," the term nearly always used to describe Germany's wartime dead. ${ }^{34}$

The details of Kalkum's demise, however, convey an ambivalent, at times, terrifying picture of German wartime experiences. The obituary described the battlefield at Verdun as a "mass murder." Attached to a machine gun regiment in the thick of battle, Kalkum

\footnotetext{
32 Josef Knecht, "Michael Messerschmidt," Academia 32 (25 March 1920): 343.

33 Volksschule

34 G. Hoppe, "Dr. Paul Kalkum AlsM" Academia 32 (25 March 1920): 339-340.
} 
never returned with his unit after enemy soldiers overran the entire position. Retreating German officers and soldiers could say nothing about Kalkum's whereabouts. Only a battalion doctor, captured and released by enemy soldiers, could later verify that a grenade had cost Kalkum his life. ${ }^{35}$

Heinrich Schmitt, a lawyer before the war, met with a similarly dubious fate. After he failed to return with his patrol from a dangerous position on the western front, his fraternity colleagues hoped for the best, but resigned themselves to the worst. Not until the beginning of 1920 would they receive the official declaration that the missing First Lieutenant Schmitt had fallen:

No pronouncement declared his last heroic deed, no comrade can report, how terrible the end of this outstanding man might be measured. He knew only warmth and magnanimity in his relations with his friends. ${ }^{36}$

The obituary of Karl Hubert Joseph Klein began with a similarly ambiguous assessment of the war: "The war is now over - the murder has come to an end. Within us remains the pain for all those who never returned to our ranks." Klein's parents, who had already lost their

\footnotetext{
35 Hoppe, "Dr. Paul Kalkum AlsM," 339-340.

36 Jakob Zwierlein, “Amtsanwalt Dr. Heinrich Schmitt," Academia 32 (25 March 1920): 346-346.
} 
eldest son to the war in 1914, received as "bitter news" his death in October 1916. The obituary continued:

For those of us who managed to make it home, a doubly bitter agony. We now miss all those who gave the blood of their hearts. For the righteous they left their lives and, now, evil triumphs.

The reference here is not entirely clear. "Evil" may refer directly to the Versailles peace settlement, which was unpopular on virtually all sides of Germany's political spectrum. Or, the term may apply more broadly to Germany's post-1918 political and economic crises.

And our thanks? A vow: struggle against injustice through word and deed, faith and unity, which we will swear until we see you again up high!37

Having lost both of his parents in childhood, Karl Schotterer made his way through college preparatory school and then enrolled at the University of Freiburg to study classical philology. There, he joined Unitas, and "remained faithful" to his fraternity until "his all-too-early death." Schotterer was among the first of the young Catholics to hurry to the flag in the "unforgettable days of August." Sentimentally attached to his native Baden, Schotterer joined a local regiment. Wounded once, he attended officer's school during his convalescence and then returned to the front. After taking ill, he returned to the front

${ }^{37}$ Seinem Bundesbruder Busch, "Karl Hubert Joseph Klein," Academia 32 (25 March 1920): $340-41$. 
again in 1917. In 1918, he received the Iron Cross, Second Class and the Service Medal of Baden. Shotterer lost his life serving on the Marne during Germany's last, ill-fated spring offensive in 1918. His surviving fraternity brothers were saddened to learn that Shotterer now rested in an anonymous grave on foreign soil: "And perhaps the little pile of dirt, like so many simple heroes' graves, will soon fall into decay, where no loving care can find its way to it." 38

Catholic contributors to the fraternity obituaries were sure to emphasize both the powerful patriotism and the heroic accomplishments of their fallen. A volunteer in 1914, Otto Lühr spent his first three years of service on the eastern front, where he saw action in Russia (including its Baltic provinces) and Romania. At the beginning of 1917, the Germany army transferred Lühr to the western front. There, Lühr proved his soldierly capabilities, when, as leader of a combat patrol, he penetrated deep into enemy lines, occupied a tactically important position and returned with a French major, a captain and 200 other prisoners. In recognition of his heroism, the army awarded Lühr with the Iron Cross, First Class. In a final letter to his fraternity brother, penned just before his death, Lühr proclaimed proudly: "For four years, I have been a front soldier and infantryman,

${ }^{38}$ K. Zeck, Studienreferander, "Karl Shotterer, stud. phil.," Unitas 60 (January 1920): 66-67. 
but in spite of their best efforts, no Russian, Romanian, Frenchman or Englishman has killed me."39

The obituary for Edmund Hartmann confirmed that the holder of the Iron Cross, First and Second Class, died after four long years of faithful service fulfilling his duty for his fatherland. 40 Lorenz Pieper described his fallen fraternity (and familial) brother, Alfons, as "full of high patriotic enthusiasm, deep rooted love of homeland and Reich, cut from a manly, soldierly sense of duty and upright in his faith in God for the flag of Germany." "Tough and unflappable," Pieper preserved these "Christian and soldierly virtues" in two years of exhausting and nerveracking armed service at the watch on the island of Helgoland. Pieper thereby earned the "privilege" to serve on a submarine. He perished on U-Boat 44 in August 1917.41

While emphasizing the patriotism and heroism of their fallen comrades, many contributors to the Catholic fraternity periodicals admitted frankly to the difficult conditions experienced by soldiers on the front. The "weak body" of Bernhard Kowalski could not stand up to the "superhuman stresses" of war. A priest who spent four years tending Catholic German soldiers in the battle fields of the eastern

\footnotetext{
39 Dobbek, "Otto Lühr," 127.

40 Siedler Mm, Lokalkaplan, "Edmund Hartmann, MM, SS, Vc." Academia 31 (15 December 1918): 176.

41 Dr. Lorenz Pieper, “Alfonz Pieper," Academia 32 (25 March 1920): 345.
} 
front, Kowalski came down with severe respiratory and intestinal disorders, which ended his life at a field hospital at Brest-Litovsk on May 26, 1918.42 The bitter conditions on the eastern front also claimed Karl Schnürch. Deep in Russian territory, Schnürch suffered from a variety of serious ailments, including pneumonia and fever. His colleague explained: "These stresses were too much for Schnürch's initially healthy constitution." 43

Dedications in the Catholic fraternity periodicals were not limited to those felled in battle, but also included the scores of Catholic fraternity victims stricken by the Spanish influenza and related epidemics that ravaged much of the globe after the war. ${ }^{44}$ These victims included Bernhard Hinteler, who had spent the months before the war's outbreak writing his dissertation in support of his Ph.D. in the Natural Sciences and Adolf Schwarz, a Doctor of Medicine, who left behind a wife, "a son in the example of his father and a blooming daughter." 45

Some ten years after the close of the First World War, Catholic fraternity periodicals continued to publish wartime material from

42 Dr. theol. Johannes Maier, Vikar, Danzig Lang-Fuhr, "Felddivisionpfarrer Bernhard Kowalski," Academia 32 (25 March 1920): 341.

43 Dr. St. Kolassa, "Med. Karl Schnürch," Academia 32 (25 March 1920): 347.

44 Including the small agricultural town of Wenatchee, Washington, where it came very close to claiming this author's grandmother, at the time just seven or eight years old. This project is dedicated lovingly and respectfully to her.

45 Cand. phil. Herkenrath, Leutnant a.D., "Dr. med. Adolf Schwarz," Unitas 59 (December 1918): 47-48. Stud. phil. Ed. Weibeler, "Dr. phil. Bernhard Hinteler," Unitas 59 (August 1919): 221. 
Catholic soldiers who had made little secret of the terror and fear they had experienced on the battlefield. In a personal letter penned on September 14, 1914, Benno Ziegler, a Freiburg medical student, described the western front as a slaughter: "O God! There are often hours, when the terrible death yields a harvest left and right...." In the same letter, Ziegler related the story of a fallen comrade, brought from the front to a field hospital:

Poor guy! Apparently, his leg will have to be amputated at the knee. Such is a small experience, which makes more of an impression than a battle against an entire French army corp.

Ziegler himself fell less than a month later, on October 8, 1914. His letter appeared in the November 1929 issue of Academia. ${ }^{46}$ The same issue included a letter from Albin Müller, theology student at the Lyceum, Bamberg. In January 1915, Müller wrote:

The rain falls on us every day. You cannot imagine, how dirty one is, wet to the skin. Today we had to lie in such muck that chilled me to the spine. But, we are restored again in God's name. And while others fled, I reflected on the story from our Holy Father Francis ${ }^{47}$, as he spoke to a brother: "And if we now come home, drenched and dirty and knock on the monastery door, and the doorman strikes us and says 'You are thieves,' brother, then we are finally truly in happy bliss." 48

\footnotetext{
46 K.H., "Kriegsbriefer gefallener CV-er. Aus dem Buche von Witkop, Kriegsbriefe gefallener Studenten (f.S. 197), Academia 42 (15 November 1929): 199.

47 An apparent reference to St. Francis of Assisi, founder of the Franciscan order (c. 1209) and celebrated in twenty-first century Catholicism for his unpretentious asceticism and gentle disposition towards animals.

48 K.H., "Kriegsbriefer gefallener CV-er, 199.
} 
Müller met his end in a field hospital in December 1915.

\section{The Role of Religion in Memorializing the War}

In the first months after the war, articles appearing in the CV's monthly periodical reflected a dominant mood among many of Germany's veterans to bring the war "decisively" to a close and "in spite of everything" to turn once again to a future of peace. But, as one CV member explained, before returning to the "everyday," it would be "worth the obligation of our fraternity" to "honor those, who sacrificed their life, blood and well being for the protection of the endangered borders of the fatherland." 49 For the $\mathrm{CV}$, the KV and Unitas fraternities, the Catholic faith played a powerful role in constructing memories of the war and in providing a vocabulary and paradigm for honoring the fallen.

In its December 15, 1918 edition of the Academic Monthly Pages, the $\mathrm{KV}$ provided an extensive review of 459 wartime letters assembled by a Professor of Church History, Georg Pfeilschifter. The author asserted that Germany's Catholics needed to "come to terms with what the war has meant for us." The first part of the collection included letters dealing with the significance of religion in the actions and lives of Catholic soldiers on the front. One letter appearing in the collection

49 "Der CV im Weltkrieg 1914-1918," Academia 31 (December 15, 1918): 182. 
claimed that Catholic soldiers had received their courage to fight from their belief in God: "When one is well prepared for the death that stares him in the eyes daily, so he loses all concept of fear." Repeating the words uttered by Christ in the Garden of Gethsemane just hours before his trial and then during his crucifixion, the letter continued: "My holiness, not what I want, but what you want. Into your hands I commend my spirit."50 Doctor of Chemistry, Wilhelm Aue, lieutenant and company leader, wrote from the front to his old pastor: "Already twenty-five years have flown by since the day that you first led me to my holy communion.... One must now think often of death and the afterlife."51

In his "Memorial Speech for the Fallen" delivered before the KV Alammania fraternity on February 22, 1919, Professor and KV alumnus Ludwig Bahr deployed the Old Testament to articulate both sorrow and honor on the occasion of a lost war. Bahr asserted that the "entire literature of the world cannot grasp the depth" of "the wonderful elegy of David for the heroes of Gilboa and his friend Jonathan."

The glory of Israel, slain upon your heights; how can the warriors have fallen.... Mountains of Gilboa, may there be neither dew nor rain upon you... How can the heroes have fallen in battle! Jonathan is slain on your heights. How I

\footnotetext{
${ }^{50}$ From Mathew 26:39, Mark 14:37 and Luke 24:47.

${ }^{51}$ K.H. "Feldbriefe katholischer Soldaten," Akademische Monatsblätter 8 (December 15, 1918): 20.
} 
do sorrow for you, my brother Jonathan: you have been most dear to me. My love for you has cost me more than love for any woman. How can the warriors have fallen! The weapons of war have perished! (II Samuel 1:17)

In the same speech, Bahr rejected the idea that the "impetuous vehemence of unbounded violence" had driven the actions of German soldiers on the front. Bahr asserted that Germany's soldiers should be remembered for their love of "the homeland, the fatherland and the brotherhood of the people." Claiming that Germany's soldiers had met a "death in God... a Christian death," Bahr claimed that German heroism had derived from a purposeful application of ideals embodied in the call: "With God for King and Fatherland!" He concluded: "you are our shining examples of faith and love for our people - In fide firmitas! ${ }^{52}$ You have made the words true. You live on in our hearts."53

In August 1929, Academia asked Erhard Schlund, the Spiritual Advisor for the $\mathrm{CV}$ and a frequent contributor to the publication, to provide his opinion on the various works of war literature that had emerged in Germany throughout the 1920s. This genre in fact defied generalization. It included both the romanticized affirmation of Ernst Jünger and the nihilistic rejection of Erich Maria Remarque. Schlund

\footnotetext{
52 In faith there is resolve.

53 "Gedächtnisrede auf die Gefallenen. Gehalten in der Trauerkneipe der Alamannia am Samstag, 22. Februar 1919 von Univ.-Prof. Dr. Ludwig Baur (E.M.d.Al.). Akademische Monatsblätter 31 (April 25, 1919): 64-66.
} 
himself had seen the front, having tended soldiers through the entire four years of the war. Most of Schlund's reviews were less than favorable. The Franciscan believed that a faithful treatment of the war must recognize the role that the Christian religion had played in the everyday lives of Germany's soldiers.

Schlund took particular offense at Remarque's All Quiet on the Western Front. Schlund testified that the soldiers he tended had been religiously dedicated, completely unlike the cynical, nihilist soldiers described by Remarque. In Schlund's words, “...religion had an entirely different meaning in the life of the soldiers and if Remarque has not appreciated that, then he has absolutely no right to write such a groundless book." Schlund conceded that many soldiers on the front had been dulled by the constant fear of death. Nonetheless, he insisted that religion had played a fundamental role in the lives of Germany's soldiers. Admittedly, Schlund had spent most of his time on the front with Bavarian Catholics. But, Schlund claimed that he had also observed the powerful presence of the Christian religion during his ten week stay in a typhus ward with Protestant Saxon troops. ${ }^{54}$

Three months later, Schlund replied to commentaries from readers who had reacted favorably to his criticism of the war literature

54 Erhard Schlund, "Der Kriegsroman und die Religion im Kriege," Academia 42 (15 August 1929): 87-90. 
genre. He wrote: "The contents of these letters prove that many others were of the same opinion, that the position of religion in the well-known war books was not properly portrayed." In his follow up article, Schlund recommended Lehmann's 1929 novel, We from the Infantry: Pages from the Diary of a Bavarian Infantryman during five years on the Front and in a Field Hospital, 55 which he believed more accurately portrayed the immediate and imminent role that religious faith had played on the front. An excerpt from this novel recounts a conversation between a sergeant and an officer, who exclaimed:

I believe in one God, who has made me, and I trust him. What evil can happen to me? Nothing, other than what he allows. Worst case: death, blindness, paralysis. Can anything that comes from him be bad? Can he mean to do evil to us? I say, belief means trust, and through that I have made it well through this whole war.

Schlund took satisfaction that the Protestant protagonist in Lehmann's book had learned to pray and found comfort in reading the Bible. Approvingly, Schlund asked: "is that not proof that religion lived in the souls of the soldiers?"56

To support his case that religion had played a fundamental role in the lives of Germany's Catholic soldiers, Schlund also made available

\footnotetext{
55 Wir von der Infanterie, Tagebuchblätter eines bayerischen Infanteristen aus fünfjähriger Front- und Lazarettzeit (Munich, 1929).

56 Dr. Leonard Gleich (A.H. Unitas-Guelfia), Vortrag, gehalten auf der Morgensitzung des 1. W.S.-Vereinfestes des U.V., München, "Moderne Kriegsliterature und Fronterlebnis," Unitas 70 (January 1930): 57-62.
} 
numerous letters that $\mathrm{CV}$ members had written from the front. In one letter, Wilhelm Wolter of Munich expressed his desire to share with the people the "rich treasures that God" had placed in his heart. Schlund offered another letter as proof that Christian love had prevailed over Catholic soldiers, even under the most difficult wartime conditions:

... with all the hate around me, I never felt stronger the power of love.... True love is the only thing that can bring us out of this surreal world. Love is eternal and, when one can grasp it, one is elevated above everything supposedly terrible. 57

In another letter included in Schlund's collection, Johannes Haas agreed that Christian love had helped Catholic soldiers through their difficult hours on the front. But more ambivalently, Haas wondered if he could resolve the inner tensions produced by the apparent conflict between his orders to serve the fatherland and the "commandment that always dwells within us: "Thou shall not kill." Less ambiguously, Willi Bohle explained in another letter quoted by Schlund: "what an extraordinary power I have found through God. I am so rich, so secure, and so fortunate." 58

Schlund also tried to confirm that belief in God had insulated Catholic soldiers from the profound fear of death that characterized

\footnotetext{
57 Erhard Schlund, "Die Religion im Kriege und in den Kriegsbüchern," Academia 42 (15. November 1929): 193-199.

58 Schlund, "Die Religion im Kriege...," 193-199.
} 
their war experiences. As Friedrich Hesse would try to reassure his parents:

God will protect me. I place my trust in my confirmation vow... If I fall, it was His will. Against that, no man can go. You have prayed for me so much, the Lord will hear you and, if he does not, then he has a special plan. He will surely not abandon you. 59

Schlund also argued that the fear of death had reinforced to Germany's Catholic soldiers the importance of fulfilling their religious obligations. In another letter offered by Schlund, Georg Stiller explained that the immediate fear of death had brought home the importance of his devotion and faith. Stiller admitted that he spent his Sundays on the front as he had rarely spent them during peace time, learning "once again to pray."

Only the danger has brought me closer again to God. I believe that there were many others like me who had forgotten God and their religion and, only through crisis and death, found their faith again. And that is not the smallest gain from this terrible war that cost us so much, but also will bring much good. 60

From his exhausting catalogue of letters, Schlund tried to prove that the great majority of Catholic soldiers had been “...religious, knew of God, wanted to hear from him, prayed to God and wanted salvation."61

\footnotetext{
${ }^{59}$ Schlund, "Die Religion im Kriege...," 193-199.

${ }^{60}$ Schlund, "Die Religion im Kriege...," 193-199.

${ }^{61}$ Schlund, "Die Religion im Kriege...," 193-199.
} 


\section{Portraying the War Faithfully and Learning its Lessons Accurately}

Contributors to the fraternity periodicals believed it their religious duty as Catholics to portray the outcome of World War I accurately and truthfully. In a lecture delivered to a fraternity function in Munich in 1930, an alumnus of the Unitas Guelfia fraternity, Dr. Leonhard Gleich, undertook a remarkably open and frank comparison of various contemporary World War I novels written by German, French and British authors. Gleich started his talk by claiming that, in the first years after the war, Germany's returning veterans had all but ignored the early novels from Ernst Jünger. Gleich explained that it was a natural reaction for Germany's veterans to pull the "veil of forgetting over the tragic face of these four years." According to Gleich, in the first years after 1918, Germany's soldiers were more interested in rebuilding or in their economic survival. They were physically and spiritually too shaken to engage in any sustained or meaningful discussions about their experiences. A full decade had to go by before those who had participated on the front could pull out their diaries and convince themselves that the violent experience had not been a dream, but an "incomprehensible" reality.

Gleich dismissed as rare and exceptional the fearless "modern gladiator" portrayed by Jünger. In contrast, Gleich quoted at length 
selections from Franz Schauwecker's Awakening of the Nation, ${ }^{62}$ which provided a very different portrayal of German soldiers in the last months of the war. To quote Schauwecker: "They stood all year long in struggle. They were starving, exhausted, soiled and poorly clothed. The munitions were of little use and in short supply."63 For Gleich, the atrocious conditions on the front did not in any way detract from the heroic accomplishments of Germany's soldiers. Again, quoting Schauwecker:

They knew that they were not any worse as soldiers than the enemy. On the contrary, they knew precisely that they had fought better and that the greater achievements were on their side. But, and that burned in them like a poisonous, barbed hook, they looked on helplessly, as they succumbed to the naked might of material and men. 64

Against over six and a half million soldiers of the French, English, Americans, Belgians and Italians the Germans in the summer and fall of 1918 stood little chance. Gleich acknowledged that Germany's opponents had commanded an overwhelming superiority in tanks, artillery, machine guns and aircraft. Three million poorly armed and poorly equipped German soldiers, with no reserves behind them, faced a seemingly insurmountable wave of machines and humanity. Many of these were to face a terrifying end:

\footnotetext{
62 Aufbruch der Nation

${ }^{63}$ Gleich, "Moderne Kriegsliterature...," 57-62.

${ }^{64}$ Gleich, "Moderne Kriegsliterature...," 57-62.
} 
They died in the bang, smoke, gas, mud and rain. They died in tunnels, shaking and suffocating. They died, corroded away from gas. They died with fire in their wounds. They died everywhere on the earth, under the earth, in the air, in dead forests, on hills and in craters.

At last, they fought without hope. They were abandoned and stood on their own. ${ }^{65}$

Gleich admonished his audience to leave an accurate and faithful memory of the war to Germany's children, warning that apocryphal portrayals of the war experience would leave an adverse impact on Germany's political landscape. He also warned his audience not to betray the memories of "our fallen comrades, whose sacrifice has become a laughable farce." In the realities of the twentieth century, Gleich warned that such willful forgetting could only lead to disaster: ...would lust for battle and bravery in the world war of the future still find a field of activity, when poison gas is available that can annihilate entire cities or armies as easily as one can blow out a candle?66

Gleich called on his audience to condemn the more belligerent variants of German nationalism and "to preserve the mentality of peace." Recognizing that Germany still faced a difficult geopolitical position against rivals like France, Gleich conceded that the German nation should not "overlook the duty" to be ready to fight against "a different thinking neighbor." Similarly, Gleich reminded his Catholic

\footnotetext{
65 Gleich, "Moderne Kriegsliterature...," 57-62.

${ }^{66}$ Gleich, "Moderne Kriegsliterature...," 57-62.
} 
fraternity audience that opting for a reserved and circumspective patriotism, rather than a more chauvinistic nationalism favored by some Germans, ${ }^{67}$ did not "mean forgetting that the German people achieved more in the greatest of all wars than any people in world history." Memories of German bravery in World War I should also be transmitted to the next generation. But, preserving "the true picture of world war" would provide Germany's next generation with a more "chastened national feeling and mature political judgment."68

In short, Gleich rejected the idea that memories of World War I should be used to mobilize the German people in support of a revisionist war of revenge. Thinking along the same lines, Cardinal Michael Faulhaber, Archbishop of Munich, instructed a Catholic fraternity audience in 1924 that "love of fatherland is quietly active love, not leadless storming passion; it is clear wine, not the must." 69 In 1925 , an alumnus of the $\mathrm{KV}$ warned that a nation of 50 million people could not commit suicide. Prophetically, he warned that anyone who might lead the German youth into an impossible liberation struggle should be branded as a criminal, if for no other reason that such actions would

67 See Chapters 6 and 7.

68 Gleich, "Moderne Kriegsliterature...," 57-62.

69 "Deutsches Ergefühl und katholisches Gewissen," 23. Thesen Sr. Eminenzes des Kardinals Dr. von Faulhaber für die katholischen Studenten," Academia 26, Nr. 12 (April 15, 1924): 61-62. 
give "our cruel enemies" an excuse to handcuff the suffering German people even more. ${ }^{70} \mathrm{He}$ was right, as the failed resistance to the French occupation of the Rhineland had proven. German attempts to sabotage the French occupation of Germany's most vital economic regions in 1923 through passive resistance had only further crippled the German economy. As explained later in this chapter, when Albert Leo Schlageter, a member of the CV and a German war veteran, tried to meet the French occupiers with violence, he was arrested, imprisoned and executed. The French occupation continued until 1930.

Franziskus Stratmann, contributing to Academia in 1925, similarly reminded his readers that Germany was not the only state to have been treated unfairly in World War I. He pointed out that the Germans themselves had extracted similarly predatory concessions from the Russians at Brest-Litovsk and the Romanians at Bucharest. He thereby situated Germany's World War I aims in the broader system of "nationalism, militarism and imperialism" that characterized state relations in the early twentieth century. Only a handful of people at the highest levels of society, Stratmann argued, could be responsible for such inhumane doctrines. These doctrines flatly contradicted the Catholic worldview. Just as there is such a thing as national dignity,

70 San-Rat Dr. Hersting, "Verband-Politik," Akadem. Monatsblätter 37, \# 1 (October 1924): 52-58. 
he reasoned, "...so there is a Christian and a Catholic." Even if Germans undoubtedly faced national humiliation in 1919 , he instructed, as Christians, they were obligated to follow certain moral standards that ruled out another world war. And he warned that any attempt to restore German national pride through a limited war would inevitably return Germany to the nightmare faced by its people during World War I and its immediate aftermath. In fact, another war would threaten Germany with wholesale destruction. He asserted:

He who thinks that a war would be like 1813,1870 , or 1914-1918, is ignorant of the new war technology. Imagine six days after the outbreak of poison gas war between Germany and France - finnis Rhenaniease and the other bordering regions. Six months later: finnis Germanieae $!^{11}$

\section{Fighting Over a Wartime Inheritance: Albert Leo Schlageter}

In the obituaries written for their fallen brothers, in their wartime letters later made available publicly, in their lectures delivered to fraternity audiences and in their contributions to Catholic fraternity publications, Germany's Catholic veterans argued that their Catholic faith had informed strongly their wartime actions, as they fulfilled their duty to the fatherland. They sought to prove that the vocabulary, paradigms and values offered by the Catholic faith had shaped their

${ }^{71}$ P. Franziskus Stratmann, O.P., "Weltkirche und Weltfriede," Academia 28, Nr. 2 (July 15, 1925): 61-62. 
efforts to construct faithful and truthful narratives of their wartime experiences. Most Catholic veterans certainly tried to distinguish their own memories of war, which nearly always lauded the sincere patriotism and heroic virtue of the Catholic soldier from the more belligerent and defiant tone of the German nationalist war narrative. On a politically unstable landscape, however, it was not always easy for Catholic veterans to locate the nebulous boundary between the two genres.

Perhaps no single Catholic war veteran embodied the conflicted, ambiguous and uncertain relationship between Catholicism and German nationalism more than Albert Leo Schlageter. A decorated veteran of World War I, Schlageter was executed by the French authorities in 1923 for engaging in sabotage in the occupied Rhineland. The National Socialist Party deployed the image of Schlageter to powerful effect in its propaganda before 1933. After 1933, the National Socialist regime elevated Schlageter to the status of heroic martyr in Germany's national pantheon. But Schlageter's CV fraternity reminded Germany's public before 1933 that the fallen hero had been one of its own. Flatly rejecting any connection between their fallen brother and National Socialism, Schlageter's Catholic fraternity insisted that its hero had been deeply imbedded in Germany's Catholic milieu. 
Albert Leo Schlageter was born to a farming family on August 12, 1894 in the Black Forest town of Schönau. According to Herrmann Hagen's biography, which appeared in a 1933 edition of Academia, Schlageter's family had lived in the same small villages in the Black Forest for centuries. "True to the wish of his parents and his own inclinations," Schlageter intended in his early school years to study theology. World War I broke out while Schlageter was still enrolled in secondary school. Before finishing school, Schlageter volunteered with Field Artillery Regiment 76 in Freiburg. After completing a short training period, from December 16, 1914 to March 7, 1915, Schlageter departed with his unit for the western front. ${ }^{72}$

Schlageter saw action in, among other places, Flanders, Arras, Champagne, Verdun, the Somme and Artois. Schlageter was wounded twice, but, each time, he returned to his troops. In June 1917, in spite of having foregone the usual officer's course of study, Schlageter was promoted to the rank of lieutenant. In April 1918, he earned the Iron Cross, First Class. Hagen asserted that the Catholic faith had played a strong role in Schlageter's life on the front. During the war, Schlageter

\footnotetext{
72 Herrmann Hagen, "Albert Leo Schlageter," Academia 46 (15 May 1933): 12-17.
} 
explained in a letter that was later cited by Hagen: "My life lies in God's hands."73

On February 28, 1919, the German Army released Schlageter from active service. Subsequently, Schlageter decided to pursue his childhood ambition by enrolling as a student of theology at the University of Freiburg. In the middle of the winter semester, 1919, Schlageter pledged the Freiburg CV fraternity chapter Falkenstein. Realizing that he did not feel called to the priesthood after all, Schlageter, "not without inner conflict," disappointed the expectations of his mother by deciding to change his major to economics. Schlageter otherwise felt very happy in his fraternity. During his later imprisonment in Düsseldorf, Schlageter would recollect on his student days and "spoke always with warmth and enthusiasm about his fraternity." "He found good men there," he purportedly explained to his visitors while awaiting his fate in French captivity. ${ }^{74}$

At the end of the summer semester in 1919, Schlageter joined up with a Free Corps unit on its way to the newly independent Baltic republics, far from his native homeland in Baden. Composed mostly of war veterans, the Free Corps were a semi-legal paramilitary institution that fought against Bolsheviks and Poles on Germany's unstable

\footnotetext{
${ }^{73}$ Hagen, "Albert Leo Schlageter," 12-17.

74 Hagen, "Albert Leo Schlageter," 12-17.
} 
eastern borders. Although typically associated with German nationalism, the Free Corps ironically enough had been authorized initially by Germany's moderate Socialist government to crack down against the Spartacus uprising at home. Even without explicit government backing, the Free Corps or organizations modeled along similar lines later put down with considerable violence leftist movements in Bavaria and the Rhineland.

After 1919, Schlageter never returned to his studies or his fraternity. When it heard nothing more from Schlageter, Falkenstein struck his name from its list of members. Nonetheless, according to later accounts, Schlageter continued to consider himself a member of Falkenstein. Hagen would later explain: "His room in his old apartment in Schönau was decorated until his death" with the symbols of his fraternity. ${ }^{75}$

After a dramatic battle, Schlageter's Free Corps unit helped local allies wrest the Latvian city of Riga ${ }^{76}$ from Bolshevik sympathizers on May 20, 1919. His unit later fought against Polish partisans in East Prussia, Pomerania and Upper Silesia. In January 1923, Schlageter

\footnotetext{
75 Hagen, “Albert Leo Schlageter,” 12-17.

76 Riga had been inhabited by ethnic Germans for many centuries. The city was also occupied by the German army during the last years of World War I. After the war, the city was besieged by Latvian nationalists, local Bolsheviks and ethnic Germans and their allies.
} 
and his comrades from the Upper Silesian action made the decision that would cost Schlageter his life, assembling under their old leader, Heinz Hauenstein, to sabotage the French occupation of the German Ruhr. The French Army had moved into one of Germany's most economically vital regions on January 9, 1923, after the German government failed to meet its post-World War I reparations obligations demanded by the Treaty of Versailles. ${ }^{77}$

On the evening of March 15, 1923 Schlageter helped to organize the bombing of a rail bridge on the Duisburg - Düsseldorf stretch. Following a tip from two of his captured comrades the French occupying authorities arrested Schlageter in April and then tried him on May 8 and 9. During his trial, Schlageter concluded: "For what I have done, I accept responsibility. I am ready to bear the consequences for my actions." He rejected a mercy plea, telling his attorney defiantly that he was "...not accustomed to begging for mercy." Just an hour before his execution, Prison Chaplain Hermann Fassbender, a CV alumnus, visited Schlageter in his cell. Reportedly, Schlageter's last wish to Fassbender was "to confess and take communion."78

The execution of Schlageter provoked an outpouring of rage and sympathy across Germany. The national CV organization immediately

\footnotetext{
77 Eberhard Kolb, The Weimar Republic (London and New York: Routledge, 1988), 46.

${ }^{78}$ Hagen, "Albert Leo Schlageter," 12-17.
} 
hailed its recently reinstated brother as a fallen Catholic hero. An August 1, 1923 issue of Academia lauded Schlageter's previous services in the Baltics and Upper Silesia and his actions in the Ruhr. Although fought for seemingly very different reasons against disparate foes, all three were seen as consistent with Germany's national honor. The article proclaimed:

For us you were the example of German faith to the death. The Cartel Union is proud to be able to name you among its own. The cross that adorns your grave is for us a symbol that you supported, suffered and struggled not just for your fatherland, but also for your worldview. 79 Celebrating Schlageter as a "Christian German," the CV excerpted numerous letters written by Schlageter to his family from the time of his capture until his execution. The letters reflect Schlageter's deep patriotism and his conviction that he had participated in a just and righteous cause. The letters also reflect Schlageter's sincere devotion to his family and his continued fulfillment of Catholic religious obligations. ${ }^{80}$

In a letter written on April 22, 1923 (before the final judgment against him), Schlageter asserted that he could breath easier knowing that everyone is his family was able to put the terror of his capture behind them. Schlageter went on to say that, had he been alone in the

\footnotetext{
79 Hagen, "Albert Leo Schlageter," 12-17.

80 Hagen, "Albert Leo Schlageter," 12-17.
} 
world, he could think of no better fate than to die for the fatherland. $\mathrm{He}$ admitted, however, that matters were not that simple and that he still worried for his family day and night. A May 10 letter from Schlageter, written on the day of his sentencing, began with the salutation: "Dear parents and siblings! Hear the last, but true words of your disobedient and ungrateful son and brother." Schlageter then pleaded with his parents and family to forgive him. Acknowledging that the letter would bring great sadness to his mother and father, Schlageter hoped that God would bring his parents strength and comfort and keep them strong in "these difficult hours." On May 25, 1923, Schlageter explained that "every person has a task on this earth." His was to serve the fatherland. "I do not fear this death. It is no disgrace, but an honor." At the end, he again asked his family to pray and trust in God. A day later, immediately before his execution, Schlageter wrote:

Dear parents! I will soon be setting out on my last journey. I will confess and take communion. To a happy reunion in the great beyond. Once again, greetings to you all: Father, Mother, Joseph, Otto, Frieda, Ida, Marie, the two Schwägers, Göttis and the entire homeland. 81

The question of Albert Leo Schlageter's legacy preoccupied the CV fraternity through the 1920s. Members were well aware of Schlageter's national appeal. However, his actions did not go without criticism.

${ }^{81}$ Hagen, “Albert Leo Schlageter,” 12-17. 
Well until the early 1930s, many Catholic press organs had criticized Schlageter for taking matters into his own hands. Some Catholics feared that Schlageter's violent actions had jeopardized the safety of the heavily Catholic population in the Ruhr and the entire occupied Rhineland. They also worried that his actions had undermined the preferred policy of passive resistance against the French. ${ }^{82}$ Some Catholics were also aware that Schlageter's connections with the Catholic CV had been severed for at least three years prior to the early months of 1923, when his highly publicized trial and execution had made him a national household name. The local Falkenstein fraternity did not reinstate Schlageter to its membership rolls until requested by his family, just weeks before his execution.

Nonetheless, some six years after Schlageter's execution, the CV celebrated the decision to erect a national Schlageter memorial in Düsseldorf. The memorial would be dominated by a towering cross, as an article in Academia explained, to bind Schlageter with his "comrades," who had died in the years 1914 to 1918 in service of the German national cause. In the same article, the CV announced that it

82 Dr. Türk, "Die Einweihung des Schlageter-Nationaldenkmals in Düsseldorf am 23. Mai," Academia 44 (15 July 1931): 72. 
was pleased that one of its own had played a part "in this honor of the entire German people." 83

Considerable public fanfare accompanied the completion of the Schlageter national memorial in 1931. An alumnus of the CV, contributing to a July 1931 issue of Academia, interpreted the massive cross erected at the site of Schlageter's death in Düsseldorf as a sacred symbol of "reconciliation and redemption." Turning to Schlageter's legacy, he exclaimed: "We must announce our faith to Schlageter. $\mathrm{He}$ was one of our own, whose ideas were pure and his will strong." 84

On May 23, 1931, the Catholic Church in Düsseldorf held a memorial service for Schlageter and the others who fell fighting against the French occupation of the Ruhr. On the occasion of the memorial, an alumnus of the $\mathrm{CV}$ alumnus asserted: "The memorial was an uplifting, deeply religious and historical hour for all participants." $\mathrm{He}$ continued:

The fallen belonged to all orders of the German people, but at the top stood our brother Schlageter, who took responsibility for his deed like a man and faced his death staring God courageously in the eyes. We did not want to celebrate this day with loud cheers or with a noisy event, but with a quiet prayer to God. 85

\footnotetext{
83 P. Derichsweiler, Mitglied des Arbeitsauschusses im Ausschuß für die Errichtung eines Schlageter-National-Denkmals, "Das Schlageter-Ehrenmal in Düsseldorf kommt," Academia 42 (15 November 1929): 222-224.

84 Türk, "Die Einweihung des Schlageter-Nationaldenkmals...," 66-73.

85 Türk, "Die Einweihung des Schlageter-Nationaldenkmals...," 66-73.
} 
After the memorial, a subdued procession, "three quarters of an hour long," moved its way through the crowded streets of Düsseldorf. German Chancellor Cuno later addressed the crowd in attendance. Referring to the massive cross symbolizing Schlageter's sacrifice, one participant in the memorial wrote: "this cross symbolizes a turning point, a symbol against all discord, all divisiveness and all death; the cross unites in one people, the idea for a true Christianity." The article concluded:

We never want to forget that Albert Leo Schlageter belonged to the CV. Every Catholic, especially, every member of the Catholic academic community and, above all else, every young member of the $\mathrm{CV}$, should take satisfaction in this fact. 86

But, at the very moment that the $\mathrm{CV}$ openly celebrated Schlageter as a hero of both Germany's Catholic community and the Catholic fraternity movement, the fraternity had to resist efforts by Germany's nationalists to stake their own claim to the Schlageter legacy. In their own press organs, some of Germany's nationalists had ridiculed the notion that Schlageter had truthfully belonged to the Catholic CV. One article charged that the fraternity had, in fact, not reinstated Schlageter until after he had "been bloodied by the bullets of the French henchmen." The right also made the potentially devastating claim that

${ }^{86}$ Türk, "Die Einweihung des Schlageter-Nationaldenkmals...," 66-73. 
Schlageter, in 1922, had registered as a member with the Nazi party. The CV would deny the first charge even after Hitler's ascension to the German chancellorship in 1933.87

As to the second charge, until 1933 , the $\mathrm{CV}$ took the position that Schlageter's membership in the NSDAP had been out of the question. To substantiate its conclusion, the CV cited a report entitled, "Shadows over the Rhine and Ruhr," appearing in a Cologne newspaper on May 3, 1931. In this article, a former French Criminal Commissioner testified that, after his capture, Schlageter had admitted that he and his collaborators were members of the Free Corps organization Oberland. As the CV would explain in Academia, "this Free Corps organization had nothing to do with the political organization of the National Socialists." 88 In May 1933, at the ten year anniversary of Schlageter's execution, the CV would be forced to make an awkward retreat from its earlier denial that Schlageter had held any connections with National Socialism. By then, Hitler had assumed power and the National Socialist regime was threatening to "coordinate" all independent associational life in Germany. Many Catholics worried that the days of the Catholic fraternities and other independent Catholic associations were numbered.

${ }^{87}$ Türk, "Die Einweihung des Schlageter-Nationaldenkmals...," 66-73.

88 Türk, "Die Einweihung des Schlageter-Nationaldenkmals...," 66-73. 
At the end of a six page article that provided a detailed biography of Schlageter, Hermann Hagen tersely addressed the perplexing issue of Schlageter's membership in the National Socialist Party. As will be explained in Chapter 7, through most of the 1920s and early 1930s, Catholic fraternity members were prohibited by both their Church and fraternity authorities from serving in the Nazi party or any of its auxiliary organizations. Up until 1933, it would have been embarrassing to admit that Schlageter could have been both a member of the CV fraternity and a registered member of the National Socialist Party. After 1933, it would have been both embarrassing and dangerous to deny a connection between Schlageter and the National Socialists, especially if one had, in fact, really existed.

The CV had always stood proud of Schlageter. Hagen also reminded his readers that the $\mathrm{CV}$ had played a central role in raising the Schlageter national memorial in Düsseldorf two years earlier. He nonetheless conceded that "these days, the National Socialist Worker's Party celebrates Schlageter likewise as one of its own and as the first casualty of the Third Reich." Concerning the question of Schlageter's membership in the NSDAP, Hagen asserted that there had been no convincing answer in the literature until the leader of Schlageter's Free Corps unit, Hauenstein, had recently testified that Schlageter, in 
October 1922, had been in possession of membership card number 1 of the Berlin Eastern Group of the NSDAP. Hagen concluded: “...therefore the question of Schlageter's membership in the NSDAP is explained." Henceforth, the memory of Schlageter would be shared by both the (soon to be dissolved) Catholic $\mathrm{CV}$ and the National Socialist regime. ${ }^{89}$

\section{Conclusion}

From 1918 to 1933, Catholic student war narratives did not conform to the pattern of mythologized nationalism as promoted by the radical right. Time and time again, Catholics described their fallen heroes as serious and dedicated, devoted to family, church and country. Catholic veterans refrained from romanticizing the war or claiming that the experience had been anything other than what it was: bloody, terrifying and traumatic. Like their nationalist cohorts, Catholics did find positive elements in the war experience. Specifically, Catholic veterans believed that their participation in the war had affirmed their dedication to the national cause. At the same time, participating in the war confirmed their adherence to their Catholic ideals.

By joining the war effort, Catholics believed that they had honored their fraternities, their families and the Catholic Church and its teachings. Still, Catholic fraternity members and alumni made it

${ }^{89}$ Hagen, “Albert Leo Schlageter," 12-17. 
clear that the war had taken them from their studies, their careers and, very often, their wives and children. The war also interfered with the fulfillment of fundamentally important Catholic religious obligations, including observing the Sabbath and participating in the holy sacraments. Finally, the war had wrenched Germany's Catholic soldiers out of the dense network of Catholic religious and social institutions that had defined Catholic life in Germany.

Catholic fraternity members did not shy away from portraying the terrifying reality of the war. They recognized that their own community and the German nation as a whole had suffered staggering losses. Further, many sought to remind their cohort that the loss of a single life, even in a war that had claimed millions, was still devastating in its implications. The war ended the lives of countless individuals who had yet to realize their dreams or fulfill their occupational callings. The war had denied Catholic parents and siblings the seemingly sacred right to enjoy the company of their children and brothers.

The Catholic soldiers claimed by the war had led complex lives. Some had already seen tragedy, including the death of one or both parents. Some had to struggle their way to the rare opportunities afforded by university study. Still, most Catholic students who volunteered for the German national cause in or after August 1914 had 
lived, up to that point, seemingly happy and socially fulfilling lives. They took their religion seriously. They approached their studies with enthusiasm. They contributed actively to the social life of their fraternities. They looked forward to graduating, embarking on a career and raising a family.

Many Catholics recognized that, in spite of the heroism, bravery and skill of the German soldier, Germany had been overwhelmed in 1918 by numerically and materially superior foes. They therefore refrained from contributing to the stab-in-the-back myth so popular among other Germans. They considered it their religious duty as Catholics to narrate their war experiences faithfully and truthfully. In spite of the war's inauspicious outcome, many fraternity members warned against any foreign policy revisionist adventurism. Nonetheless, Catholic veterans rejected the nihilism of Remarque. Catholic participation in the war did have meaning and it did serve an important purpose. Catholic soldiers serving on the front confirmed their devotion to the German national cause. As Catholic veterans were quick to point out, they had done nothing less than fulfill their duty to God and to the fatherland. 


\section{Chapter 3}

\section{A Republic in Crisis}

What do millions of fallen soldiers mean to us today? In the time of hyperinflation, we had to calculate the value of currency in trillions. Millions upon millions have lost their last emergency pennies. Millions upon millions are without work and bread. Millions have to be expended just to ameliorate the worst of the emergency conditions. And, year after year, we have paid billions upon billions of Reichsmarks as tribute to foreign powers. Academia, November 15, 1932. ${ }^{1}$

News of the armistice ending the Great War hit the German population just before the holidays. In four long years of carnage, empires, kings and millions of people had vanished from the earth. In the aftermath, a fractured German population struggled to come to terms with the collapse of its ruling dynasty and the outbreak of revolutionary chaos in many of its urban centers. In Münster, a Catholic fraternity alumnus wrote in the December edition of Unitas that Germany's Catholics would be celebrating a "nervous" Christmas. ${ }^{2}$ In early 1919, Socialist Party leader Friedrich Ebert prepared to commission Germany's leading legal minds to write a new constitution for a new republican government. At this potentially transformative

1 "Der Volksbund Deutsche Kriegsgräberfürsorge," Academia 45 (15 November 1932): 183.

2 Dr. U. Donders, "Weihnachten 1918: Aufblick zum Stern von Bethlehem," Unitas 59 (December 1918): 49-52. 
moment in German history, leading Catholics insisted that this foundational document enshrine the principles of Christianity. As the contributor to Unitas argued, the "great buzz" words of revolution swirling in the air, such as "freedom, right, order, justice, and social welfare" had sprung forth long ago from the Christian peoples of a dying Roman Empire. Only during the Middle Ages, when the Holy Roman Empire and a unified Christian Church fulfilled their roles seamlessly as equal partners had these principles been realized genuinely in political and social relations. For a number of complicated reasons, the age of industry and the rise of the unitary national state had seen their near eradication. But Germany's leadership now had a genuine chance to start anew. Without recognizing the importance of Christianity in reconstituting German society, warned the Unitas contributor, the politicians of 1918 would get the form, but not the content of revolution right. ${ }^{3}$

\section{A Complicated Inheritance}

How would Christianity inform Germany's constitutional experiment in 1919? As a literal guide to constitution writing, JudeoChristian scripture is philosophically and historically unhelpful. True, under Kings David and then Solomon, the Israelites consolidated

3 Donders, "Weihnachten 1918...," 49-52. 
political authority in a single capital city, inaugurated the construction of monumental architecture embodying both religious and secular authority, and transcribed into covenant-constitution and epic myth the unwritten norms, conventions and oral histories of pastoral peoples. For a time, the community of Israel lived within a recognized set of sovereign boundaries, under a unitary body of law and a single head of state.

But this should hardly to be read as God's sanction for monarchy, or any form of government, for that matter. For much of its early history, Biblical Israel was not ruled by a hereditary monarch, but by tribal elders who appointed leaders (Judges) for specified functions, usually, to mobilize an otherwise decentralized people against a common foreign foe. When the pivotal moment in Israel's national history arrived, when its elders demanded a king "as other nations have," God consoled a disturbed Samuel by saying: "Grant the people's every request. It is not you they reject, they are rejecting me as their king." 4 Through Samuel, God warned his people that a king would draft their sons into his army, expropriate the best of their fields, vineyards and olive groves, tax their crops and apportion the revenues to his eunuchs and slaves. "When this takes place, you will complain

\footnotetext{
41 Samuel 8:8 (The New American Bible, 1969).
} 
against the king whom you have chosen, but on that day the LORD will not answer you."5 To serve one last warning, Samuel called down thunder and rain, at harvest time, no less. ${ }^{6}$ Defiant to the end, the Israelites begged Samuel, 'Pray to the LORD your God for us, your servants that we may not die for having added to all our other sins the evil of asking for a king."

God's warning proved to be unsurprisingly prophetic. Israel's unified monarchy lasted less than a century. By the end of Solomon's reign (965-928 BC), Israel's subjects chafed under the heavy taxations and forced labor required to sustain the king's monumental building projects. Even worse, Solomon violated the covenant's call for spiritual and reproductive purity by acquiring foreign wives and dedicating temples to their foreign gods. In the years following his death, Israel split into northern and southern realms, both destined to be overrun and dispersed in the following centuries.

As far as the art of state-building is concerned, the Christian New Testament is likewise of little guidance. When pressed by Pontius Pilate to clarify his position vis-à-vis the Jews under Rome's jurisdiction,

\footnotetext{
51 Samuel 8:10-18 (The New American Bible, 1969).

61 Samuel 13:17 (The New American Bible, 1969).

71 Samuel 13:19 (The New American Bible, 1969).
} 
Jesus Christ responded: "my kingdom does not belong to this world." The Pauline epistles provide little in the way of productive constitutional advice beyond admonishing the followers to hold fast to their faith and in the meantime, to pay their taxes whenever called upon.

An early Church father of the fourth and fifth centuries, St. Augustine, Bishop of Hippo, authored the seminal text of early Church theology, The City of God, in part, to supplement the Scripture's sparse guidance on practical politics and government. Augustine advanced from the assumption that human society, as a consequence of the original sin, was divided between the saved and the damned, between those destined for heaven, and those destined for hell. The state, Augustine argued, existed primarily for the benefit of those who had chosen to live according to the "law of the flesh," meaning in more philosophical terms, those who had grown to love God's temporal creations, rather than God.

True, conceded Augustine, the state also protected the saved. But of course, these very few good men and women have little reason to fear for their safety or their lives. After all, what is fear to one who is promised eternity? "Whoever finds his life will lose it, and whoever

\footnotetext{
8 John 18:36 (The New American Bible, 1969).
} 
loses his life for my sake will find it," as he might remind his reader. ${ }^{9}$ Or, "... no one has ever died who was not destined to die some time. Now the end of life puts the longest life on a par with the shortest."10 As for the damned, God still has compassion for them while they are here on earth. This is why the state exists primarily for their benefit. As Dino Bigongiari, a prominent twentieth century St. Augustine commentator, explained:

These latter, always the majority of human beings, act immorally, because they have no grace... The state is necessary because these people, with all their greed, with all their desires, would otherwise soon have exterminated themselves. To prevent such extermination, God permitted, he did not create, but permitted - the constitution of states. ${ }^{11}$

Following Bigongiari, Henry Paolucci would add that the "worldly regimes" proposed by St. Augustine "exist for the mutual restraint of the wicked." They enforce a genuine good, namely peace. But this is the same kind of peace that is enforced when "straitjackets" are employed against the "violently insane." Paolucci explained that such a peace would be desirable "... even if those who bind are neither less

\footnotetext{
${ }^{9}$ Mathew 10:37 (The New American Bible, 1969).

10 Saint Augustine, The City of God (New York: The Modern Library, 2000), 16.

11 Dino Bigongiari, "The Political Ideas of St. Augustine," from the lecture series, The Philosophical and Political Backgrounds of the Divine Comedy, reprinted in the Appendix of St. Augustine, The Political Writings, introduced by Henry Paolucci (Regnery Publishing: Washington, D.C., 1962, 1996 paperback edition used here), 344-345.
} 
demented nor less violent than those who are bound. It suffices only that they be more powerful." 12

From this line of reasoning, Augustine would endorse any form of constitution that secured order. In the meantime, the state's laws need not be Christian, or even normative in content. True, Augustine was known to argue for leniency and clemency in punishing criminals, in part, so that they might live to be returned to the Christian fold. $\mathrm{He}$ likewise did not object when the authorities of his day punished heretics or other non-conformists. But, these actions are incidental to the broader purpose of the state, as he understood it. Because the state's law deals with this world (following Christ's response to Pontius Pilate), Christians, while in this world, are obligated to obey their rulers. This holds true even when the content of the law fails to affirm their Christian principles and beliefs. Christian subjects may disobey their authorities only if they are asked to violate explicitly God's law. Even here, they must accept the state's consequent punishment for disobedience, even if it means death.

Intriguingly, Augustine's "Two Cities" argument shares certain affinities with various (not always consistent) tenets of constitutional

\footnotetext{
12 Henry Paolucci, Introduction to St. Augustine, The Political Writings, introduction by Henry Paolucci (Regnery Publishing: Washington, D.C., 1962, 1996 paperback edition used here), $\mathrm{xx}$.
} 
liberalism. Most directly, it shares with Thomas Hobbes, John Locke and the later framers of the U.S. Constitution the belief that grace is an intimately private matter, to be negotiated ultimately between the individual and God. ${ }^{13}$ While Augustine accepted the state as supreme in its realm, the connection between state and subject is allowed to be surprisingly minimalist. The state, after all cannot save what only God can save. States can protect physical bodies in the meantime. But they need do this and only this. Living the moral life, on the other hand, becomes a question of God's grace, nothing else.

Certain elements of Augustine's thinking can be found in Catholic political theology well into the twenty-first century. To Pope Leo XIII (1878-1903) is sometimes attributed the seemingly Augustinian position known to Catholic commentators as "accidentalism." According to this belief, while the Catholic Church may favor certain forms of government, it would be willing to tolerate any constitutional form that did not threaten the Church's religious prerogatives over its believers. ${ }^{14}$ Accidentalism in part allowed Germany's Catholics to make their peace with their Protestant Hohenzollern rulers after the Kulturkampf finally

\footnotetext{
13 Not incidentally, this position was also shared by Martin Luther, a member of the Augustinian order before his break with the Church. ${ }^{14}$ Noel Cary, The Path to Christian Democracy: German Catholics and the Party System from Windthorst to Adenauer (Cambridge and London: Harvard University Press, 1996), 22.
} 
subsided in the 1880 s. Catholics likewise accepted Augustine's

admonition to obey their legitimate rulers after the establishment of the Weimar Republic in 1919.

\section{The Angelic Doctor and Weimar}

It is fair to say, however, that Germany's Catholics were even more impressed by another authority, St. Thomas Aquinas (1225-1274), the redoubtable voice of Catholic political doctrine of the High Middle Ages. To make sense of the constitutional trajectory as mediated by St. Thomas, it is helpful to remember that the man still revered by the Catholic Church as its Angelic Doctor took for his qualified inspiration Aristotle. In Aquinas' day, Islamic commentators had only recently restored the Greek philosopher to Latin Christendom. Regarding monarchy (Germany's form of government up to November 1918), St. Thomas followed a distinctively Aristotelian line of reasoning, when he asserted famously that "just as the most efficacious cause of heat is that which is by its nature hot.... the rule of one man is more useful than the many."15 It is no surprise that many Catholic German

\footnotetext{
15 From On Kingship, as excerpted in The Political Ideas of St. Thomas Aquinas, edited with an introduction by Dino Bigongiari (The Free Press: New York, 1953; First Free Paperback edition 1997), 180.
} 
theologians in the late 1800 s and early 1900 s endorsed the Hohenzollern monarchy on these grounds. ${ }^{16}$

But, they might have been reminded that Aquinas attached to this argument all the trademark Aristotelian conditions. Throughout his celebrated Summa Theologica, Aquinas argued that the ideal government should combine the best elements of all three constitutional options laid out by the Philosopher. ${ }^{17}$ These were: monarchy, aristocracy and democracy. ${ }^{18}$ Whether the political community is ruled by one, a few, or many, a good constitution should ensure that rulers promote the general welfare. Aquinas shared Aristotle's belief that any constitutional arrangement ran the danger of degenerating into its alter ego, a situation in which the authorities ruled out of their own interests, rather than the people as a whole. ${ }^{19}$

Initiating a tradition later joined by Montesquieu and the framers of the U.S. Constitution, Aquinas without qualification asserted that

\footnotetext{
${ }^{16}$ For a detailed and immeasurably informative survey of German Catholic theology during the Imperial period, see Thomas F. O'Meara, O.P., Church and Culture: German Catholic Theology, 1860-1914 (Notre Dame and London: University of Notre Dame Press, 1991).

17 the medieval shorthand name for Aristotle

18 Admittedly, in Aristotle's vocabulary, democracy is a degenerated form of "polity," but since this word has all but disappeared from our political vocabulary, I resort to the former for clarity and convenience.

19 This was possible even in a democracy, insofar as demagogues are able to manipulate politics to secure individual ends. Like Rousseau, Aristotle would recognize that the will of the majority, or even the will of all (as the sum total of all individual wills), should never be confused with the general will.
} 
under any arrangement, the rule of law should prevail. ${ }^{20}$ He would go on to say that the form of constitution ("the right ordering of rulers in a state or nation") that "ensures peace among the people" and is therefore the "most enduring" is one that allows all to take share in the government. As he would elaborate:

For this is the best form of polity, being partly kingdom, since there is one at the head of all; partly aristocracy, in so far as a number of persons are set in authority; partly democracy, i.e., government by the people, in so far as the rulers can be chosen from the people and the people have the right to choose their rulers. ${ }^{21}$

Although the influence of Aristotle is unmistakable, Aquinas rested his argument on the Biblical precedent of Moses, who ruled over the perfect polity: a single leader and 72 appointed elders from the various tribes, based on a legitimacy that was ultimately "a democratical government." Although a kingdom was theoretically the "best form of government" in the sense that it embodied the unified virtue of a single human being, again echoing Aristotle (and Samuel), Aquinas warned that "since the power of the king is so great, it easily degenerates into tyranny." Although monarchy, or more broadly, one-person-rule might be the

\footnotetext{
20 From Summa Theologica I-II, Question 95, Fourth Article, as excerpted in The Political Ideas of St. Thomas Aquinas (Bigongiari), 64.

${ }^{21}$ From Summa Theologica I-II, Question 105, Second Article, as excerpted in The Political Ideas of St. Thomas Aquinas (Bigongiari), 87-88.
} 
most efficient form of government, concluded Aquinas, it was also potentially the most dangerous. ${ }^{22}$

St. Thomas took the rather unorthodox, and in his time, potentially heretical position that the human intellect was capable of apprehending God's wisdom through the terms of the natural universe. Human beings, as he reminded his reader, following Aristotle, were not endowed with the physical tools to get on in the natural world without sophisticated forms of cooperation. It thereby stood to reason that God intended the state, the most sophisticated cooperative form of all, as part of the natural order. Aquinas likewise agreed with Aristotle that outside of the political community, human beings are either beasts or gods (figuratively, in the Christian sense), in other words, not human at all.

Rejecting, even if at pains to avoid doing so explicitly, the older Catholic tradition dating to St. Augustine, St. Thomas believed that political authority must do more than restrain wicked people. "On the contrary, the Philosopher says that the intention of every lawgiver is to make good citizens." He continued

...it is evident that the proper effect of law is to lead its subjects to their proper virtue; and since virtue is that which makes its subject good,' it follows that the proper

22 From Summa Theologica I-II, Question 105, Second Article, as excerpted in The Political Ideas of St. Thomas Aquinas (Bigongiari), 87-91. 
effect of law is to make those to whom it is given good, either simply or in some particular respect. ${ }^{23}$

Following Aristotle, St. Thomas would argue that lawgivers and their laws make good citizens by habituating them to proper conduct. ${ }^{24}$

If one shares Aquinas's position, then the content of law matters and so does the content of the constitution and the state. If laws are to have the maximum moralizing effect within a state that also ensures stability, Aquinas would seem to make clear that the state's constitution must be participatory. Stated another way, the constitution must encourage the broadest possible commitment from its subjects. The very act of participating in the political community becomes a kind of moralizing mechanism, habituating citizens to virtue. Encouraging participation also ensures that people will believe in and uphold their constitution. ${ }^{25}$

${ }^{23}$ From Summa Theologica I-II, Question 92, First Article, as excerpted in The Political Ideas of St. Thomas Aquinas (Bigongiari), 24-25.

${ }^{24}$ From Summa Theologica I-II, Question 92, First Article, as excerpted in The Political Ideas of St. Thomas Aquinas (Bigongiari), 24-25.

25 The argument here is complex. Like Aristotle, St. Thomas realized that not all constitutional forms were appropriate for particular peoples. St. Thomas agreed with the Augustinian proposition that "If the people have a sense of moderation and responsibility, and are most careful guardians of the common weal, it is right to enact a law allowing such a people to choose their own magistrates for the government of the commonwealth." This condition would not hold, however, if the people did not have this sense of moderation. However, to rely again on Bigongiari, people by their nature have an aspiration "to liberty and equality, which manifests itself in the claim to participate in public life. This is so strong that refusal to satisfy it may bring about dissension, which evil must be avoided at all costs." To quote St. Thomas directly: "In the earthly states... the variety and the abundance of public functions and roles helps to preserve unity, because through them a great number of people are enabled to take 
Aristotle would say that we are inherently political species beings. In the properly constituted community, we do not participate in politics merely to achieve an incidental end, such as material reward, influence or power. We participate in politics to achieve a higher end, an end in itself, or Telos. For Aristotle, this Telos signifies the maturation process whereby the individual transitions from childhood dependency to a fully responsible human being. Aquinas would agree, and would argue likewise that this maturation process has its ultimate end in salvation. On one very critical issue, St. Thomas Aquinas found almost total agreement with his predecessors. Like St. Augustine, St. Thomas rejected violent revolution against the existing authorities. He fully recognized that the world's history had been littered with tyrants, or people who violated the law and ruled out of their own selfish interests, rather than the interests of their subjects. But St. Thomas nonetheless

part in public activities." The Political Ideas of St. Thomas Aquinas (Bigongiari), preface, xxix, 79. This is consistent with Aristotle's Politics, Book 3, 11 "The principle that the multitude ought to be supreme rather than the few best is capable of satisfactory explanation... when they meet together [they] may very likely be better than the few good, if not regarded individually, but collectively.... For each individual among the many has a share of virtue and prudence, and when they meet together they become in a manner one man, who has many feet, and hands, and senses." By way of analogy, "... the many are better judges than a single man of music and poetry; for some understand one part, and some another, and among them, they understand the whole." Again, the operative principle is civic peace and the avoidance of dissension. Although there is a danger in letting the common people share in the highest office, there is likewise a danger in excluding them from office altogether. This will leave the polis "full of enemies. The only way of escape is to assign to them some deliberative and judicial functions." Aristotle, Politics (Mineola: Dover Publications Inc., 2000), 121-122. 
rejected revolution for two fundamental reasons. First, as his commentator Bigongiari would put it: "tyrants come into the world with God's consent, to punish the wicked and to test the good." Agreeing with St. Augustine, St. Thomas conceded that political authority is willed, or at least allowed by God. Human beings do not have the right to question God's wisdom. Second, and perhaps even more importantly, resisting evil with violence can produce even worse evils, including fatal dissensions among the body politic, and even more offensive forms of tyranny. ${ }^{26}$ In keeping with his reading of the New Testament, which offered the example of the early Christian apostles, St. Thomas strongly preferred the martyr over the revolutionary. ${ }^{27}$

The Catholic Church has accepted Thomas Aquinas as its authoritative voice on political philosophy for centuries. The Church considered St. Thomas to be its most reliable source of authority in the violent century of Reformation and Counter-Reformation starting in 1517. Leo XIII affirmed the Angelic Doctor in his encyclical Aeterni Patris, on August 4, 1879.

\footnotetext{
26 The one critical exception to this rule is as follows: if the tyrant himself rules so egregiously contrary to the common good, that the tyrant himself is guilty of sedition. Even here, efforts to overturn such rule may not produce a consequent disturbance such that the tyrant's subjects suffer even greater harm. Summa Theologica II-II, Second Article. Bigongiari, 94-95.

27 From Dino Bigongiari's introduction to The Political Ideas of St. Thomas Aquinas, xxxii.
} 


\section{An Appraisal of Weimar Democracy}

Through the Weimar period, Thomas Aquinas impressed particularly Germany's Catholic fraternities. Mathias Maria Bigge, writing for the Unitas journal on the occasion of the 600 year anniversary of Aquinas' canonization in 1923, confirmed that through the ages "the influence of St. Thomas has shone on us with the living effect of the sun... illuminated both in holiness and learnedness." He continued: "in the confusion of today" the German student body "should look back to the clear principles of his political and societal teachings to find salvation. We can all learn something from the holy Thomas." 28

How would St. Thomas Aquinas have evaluated the radical constitutional changes that transformed Germany from a monarchy to a parliamentary republic in the months after the close of World War I? Although over six centuries separated the Angelic Doctor from Weimar, Catholic commentators nonetheless through the 1920 s would consider this to be a legitimate and worthwhile question.

Like many Germans, Catholic fraternity members faced the departure of the Hohenzollern monarchy (and in Bavaria, the

\footnotetext{
28 Mathias Maria Bigge, O.P. "St. Thomas von Aquin, Zum 600 Jahrestag seiner Heiligsprechung," Unitas 63, Nr. 7/8 (April/May 1923): 109-111.
} 
Wittelsbach dynasty) with a feeling of unease that bordered on trepidation. At a lecture delivered to Catholic fraternity members and academic officials in Düsseldorf, Dr. Hunele, an alumnus of the CV, argued that "the living work of the Hohenzollerns has gone to the grave," and that the German people now faced "cloudy, fateful days." True, he reminded his reader, under the watch of the Hohenzollerns, the industrialization of the past decades had come at the cost of an alienated countryside. Even worse, the fast paced "Americanization" of Germany's great cities and industrial centers had wrenched millions of Germans out of their native habitus. Hunele observed nostalgically, however, that the German nation had made great progress under the Hohenzollerns, especially in university education, work production and technical progress. ${ }^{29}$

When it came to the question of democracy, Catholic fraternity writers had little problem with the one position in Germany's new constitutional framework elected by the entire German population, namely, the President. With some justification, later historical commentators like Hans Mommsen have been heavily critical of this

29 Von Sanitätsrat Dr. Hunele, Hr, Bd. "Christlicher Akademiker und politisches Leben," Academia 32, Nr. 1/2 (15 June 1919): 2-7. 
institution, likening it to a kind of substitute monarch. ${ }^{30}$ Indeed, Mommsen argues that the triumph of the presidential paradigm, so alien to the parliamentary tradition, anticipated the "inner rejection" of the republic. That the President derived his legitimacy directly from the German people, enjoyed independence from the legislature and exercised considerable powers would have accorded fully with the Aristotelian reading of St. Thomas, however. The President was selected from all the German people, by the German people, and did answer to the law. The President worked in a system that also featured other elements of Aristotle's three ideal types, including participatory parliamentary democracy.

Germany's fraternity writers rarely if ever criticized this institution. In particular, the second president of the Republic, Paul von Hindenburg, enjoyed substantial good will among Germany's Catholic population, even though he had won his electoral mandate in 1924 by beating out a Catholic fraternity alumnus, Wilhelm Marx. On the occasion of the president's $80^{\text {th }}$ birthday, a contributor to a fraternity journal hailed Hindenburg as a "national hero," as Germany's most faithful and greatest son, and as "a shining example of fearless

30 Hans Mommsen, The Rise and Fall of Weimar Democracy (Chapel Hill and London: The University of North Carolina Press, 1996 English translation), 57. 
trust in God." 31 Catholic fraternity writers approved proudly in 1930 when the "all revered" Hindenburg appointed a Catholic fraternity alumnus, Heinrich Brüning, to the German Chancellorship. ${ }^{32}$ In short, Germany's Catholics might have preferred this substitute form of monarchy to the real monarchy that had preceded it.

While Catholic fraternity writers endorsed presidential democracy, they were far more ambivalent in their assessment of parliamentary democracy. To review briefly, Germany's 1919 constitution had enshrined parliament as the sovereign institution of the nation. True, Article 48 of the constitution authorized the president to dissolve parliament and rule by decree in emergency circumstances. But the writers of the constitution had contemplated this arrangement as exceptional, not as an ordinary state of affairs. ${ }^{33}$ Otherwise, the writers of the constitution established the Reichstag as Germany's supreme legislative authority. In a departure from the Kaiserreich, the German Chancellor would now require the Reichstag's confidence. The

\footnotetext{
31 "Hindenburg," Der Ring 3 (Nebelung 1927): 89.

32 Of course, they were only partially informed as to Hindenburg's real motives in doing so. "Reichskanzler Dr. Heinrich Brüning Bd!" Academia 42, Nr. 12 (15 April 1930): 367.

${ }^{33}$ See Detlev K. Peukert, The Weimar Republic: The Crisis of Classical Modernity (New York: Hill and Wang, 1983, first paperback edition of 1993 used here), 39-40. Eberhard Kolb substantially agrees, although he also suggests that Article 48 reflected distrust towards parliamentary institutions by some constitutional contributors. Eberhard Kolb, The Weimar Republic (London and New York: Routledge, 1988), 18-19, 148-149.
} 
Chancellor in turn would play a major role in the formulation of German foreign policy.

To reward the Reichstag with the highest popular legitimacy, the Weimar constitution accorded the right to vote to all German men and women of the age of 20 . Votes would be counted equally and proportionately, meaning that party delegation apportionment in the Reichstag would reflect the actual percentage of votes received by each party received nationwide. In a major departure from the Kaiserreich, the Weimar constitution shifted the preponderance of power from the state governments, where it had been before 1919 , to the national government in Berlin. This decision was important for a number of reasons. In the past, many of Germany's constituent state principalities had weighted voting rights according to wealth or other restrictive criteria. Most notoriously, Prussia, which was by far the largest constituent entity in the Reich, had deployed a three-tiered system that effectively disenfranchised the poorer elements of the population, particularly the working class. Restrictive franchises had also been deployed in Saxony and Hamburg. ${ }^{34}$ With the center of political gravity now firmly in Berlin, it was hoped that Germany's

34 David Blackbourn, The Long Nineteenth Century: A History of Germany, 1780-1918 (New York and Oxford: Oxford University Press, 1998), 409-410 
citizens would have a more equitable share in contributing to the decisions that affected their daily lives. ${ }^{35}$

The notion of parliamentary sovereignty enshrined in Weimar's constitution should have accorded reasonably well with a Catholic understanding of politics. As St. Thomas instructed, good constitutions enhance the moral qualities of their subjects by encouraging their participation in the making and execution of the law. But through the 1920 s, the approach of Catholic fraternity members to the question of democracy remained fluid. As early as December 1918, a contributor to the Unitas journal claimed that democracy, "the old friend of our Franciscan religious culture, is congenial to our Catholic make up."36 Not all Catholic fraternity observers were so optimistic, however. On the question of participation in legislative decision making, Dr. Hunele of the CV observed that some two-thirds of the delegates to the last Imperial Reichstag hailed from university educated backgrounds. In the newly elected National Assembly, this figure had dropped to onethird. According to Hunele, the new election laws pushed through at

\footnotetext{
35 A number of observers blamed the overly democratic voting system, and particularly proportional representation (PR) for the proliferation of splinter parties that made coalition formation extraordinary difficult, if not downright impossible. In fairness, PR is used on most of the European continent today, usually with less dramatic consequences.

36 Jürgen Schwarz, Studenten in der Weimarer Republik: die deutsche Studentenschaft in der Zeit von 1918 bis 1923 und ihre Stellung zur Politik (Berlin: Duncker \& Humblot, 1971), 133-134.
} 
the insistence of the Social Democratic Party (Germany's leading party in early 1919, and ironically, one of the national coalition partners of the Catholic Center Party) were to blame - they rewarded simple numbers, not merit or accomplishment. ${ }^{37}$ As a consequence, he argued, the spiritual depth of Germany's new parliament had suffered. ${ }^{38}$ A contributor to the April 25, 1920 edition of Academia lent credence to historian Louis Snyder's redoubtable (if now partly questionable) assertion that: "If it is true that a democracy can be successful only if it is wanted by the people, then the German democracy was doomed from the very start."39 In this article, Herr Von Reinele of the CV fraternity ridiculed the idea propagated by other recent contributors to the publication that democracy should be seen as a "cure for all pains in state and society." Democracy, he insisted, derived from the fallacy of the French Revolution that held the state to be merely an agglomeration of discreet individuals. Likewise, Rousseau contributed a fundamental error to the doctrine of democracy by

\footnotetext{
${ }^{37}$ Interestingly, when it served the Catholic cause, Hunele approved of the new liberalization of German voting rights, especially when it concerned women. Hunele viewed affirmatively the newfound right of Germany's women to vote. He seemed to believe, probably not without good reason as far as Germany's contemporary Catholics were concerned, that voting women would work to the advantage of Germany's politically active Christians. It was to the Catholic's advantage to "capitalize" on this newfound source of electoral strength.

38 Hunele, "Christlicher Akademiker und politisches Leben," 2-7.

39 Louis Snyder, Roots of German Nationalism: The Sources of Political and Cultural Identity 1815-1976 (New York: Barnes \& Noble Books, 1978), 158.
} 
asserting that, since the people are naturally good and equal, the will of the people can be found in the pure majority. ${ }^{40}$

When applied to the modern industrial society, Reinele argued, democracy simply encouraged class conflict and the pursuit of material self interest, leading to the brutal rule of the masses. As he explained, "The rule of the majority is in practice nothing else than the dictatorship of the proletariat" in which the politically trained, educated and culturally productive classes are shoved aside. ${ }^{41}$ In Reinele's opinion, political decisions should be left to the expert. He insisted: "Non-swimmers should not be allowed in the sea, one cannot let children go through the drawers of the medicine cabinet, and women and the elderly are kept off the battlefield." Since this is the case, he continued, why in "the difficult matters, in politics, should all barriers and distances fall?"42

Reinele claimed that only a proper education could endow a citizen with the real freedom of thought necessary to make informed political decisions. Workers, artisans and even many leaders in business simply did not have the spiritual horizon, or the logical

40 It is this author's own opinion that von Reinele is mistaken. Rousseau makes very clear in The Social Contract that the general will (that which is in the interest of society and which can never err) should never be confused with the will of the majority or the will of all, which may signify something different - the sum total of selfish and/or selfinterested individual wills.

41 Von Reinele, "Demokratie," Academia 32, Nr. 12 (25 April 1920): 357-360.

42 Reinele, "Demokratie," 357-360. 
strength of thought needed to participate in politics. Reinele described politics as "a large mass of problems" that required an understanding that only an individual with high training and expertise could grasp. The great masses, he warned, were susceptible to party fanaticism and were influenced too easily by popular literature and demagogues. Most people, whose "only spiritual bread" was the daily newspaper, simply did not have the capability to know their own interests, much less the interest of the greater good. 43

Reinele's portrayal of historical democracy was far from favorable. ${ }^{44}$ He characterized the Athens and Rome of antiquity as the centers of "loudmouths and spectacle makers." The antique world did offer a better example of effective government, namely, the thoroughly aristocratic state contemplated in Plato's Republic. Plato proved that the foundation for a capable state is the leadership of absolute experts, unhindered by the masses. Reinele insisted that he had sanction for his ideas from all the "great thinkers" of the Christian cultural circle, including St. Augustine, St. Thomas Aquinas, Joseph de Maistre, and Joseph Görres. Even Goethe had supposedly opposed democracy:

Everyone called to his order, every order within its boundaries, and all orders in their boundaries to

43 Reinele, "Demokratie," 357-360.

44 Reinele, "Demokratie," 357-360. 
collaboration - not co-governing - that was his ideal state. 45

Evidently, Schiller was of the same opinion. ${ }^{46}$ Most importantly, the Church, both historically and in his present day, was in agreement. On the one hand, through its long history, Church offices had been open to anyone, regardless of birth. Even Peter's chair had been open to the lowest born. But, opined Reinele, on the other hand, the Church has always understood and emphasized that talent was the principle of the division of labor. Never had the Church allowed the unprepared believers to make decisions about doctrine and practice. "Only to the successors of Peter and the Apostles is the understanding of Christ entrusted." ${ }^{4}$ So it was for the Church, averred von Reinele, so it should be in politics.

From the standpoint of the Catholic fraternities, Reinele's rejection of democracy tended towards the extreme side of the spectrum. In a more characteristically moderate line of argument, a contributor to the October 15, 1927 edition of Academia asserted that, in any state, Catholic morality required the citizen to accept the legitimacy of the law and the ordering of authority. No state, counseled

\footnotetext{
45 "Jeder in seinem Stande, jeder Stand in seinen Grenzen und alle Stände in ihren Grenzen zur Mitarbeit - nicht zum Mitregieren - berufen - das war sein Staatsideal.” 46 Reinele, "Demokratie," 359.

47 Reinele, "Demokratie," 357-360.
} 
Dr. Ernst, a CV alumnus, can function without an organization of governing and governed. But it did not thereby follow that a state could not function without the alternating of subject and authority. It similarly did not follow that one who was in authority must remain in authority, or that one who was a subject must remain so. 48

True, argued Ernst, Catholics should worry about the excesses of democracy. A democratic system offers many possibilities for mistrust, he conceded. He alluded to the recently demised Prussian monarchy (which he interestingly recognized as a limited form of democracy), with its doctrine of the omnipotence of the state and its preference for Protestantism. Corruption, driven by the influence of money, was likewise very possible in the democratic state. The democracies of the west, France and the United States of America, supposedly proved it. The Catholic politician must never believe that democracy is perfect, or that it could not be improved. 49

Power, Dr. Ernst reminded his reader, is willed by God. The only difference between the Kaiserreich and the Weimar Republic was that power was no longer mediated in the name of the Kaiser, but in the name of the people. Center Party Representative Joseph Mausbach,

48 Dr. L. Ernst, "Katholizismus und Politik: Grundsätzliche Erwagungen," Academia 40, Nr. 6 (October 15, 1927): 136-142.

49 Ernst, "Katholizismus und Politik...," 136-142. 
also a Professor of Apologetics and Moral Theology at the University of Münster, had recognized this principle when he participated in the writing of the Weimar constitution. So, concluded Dr. Ernst, ....we find no principle from the standpoint of Catholicism against the democratic state system. Should we personally prefer another state form or state constitution is not to be debated here. 50

Whatever their reservations about Germany's new constitutional order, it should come as no surprise that virtually all Catholic commentators held to Aquinas' unqualified rejection of violent revolution against the legitimate secular authorities. Dr. Ernst called on the authority of Romans $13: 1^{51}$ to remind his readers in 1927 that Christian morality ruled out violent changes to the constitution or the existing governing structure. Political conflict, in his opinion, could be "mediated only through the boundaries of law, constitution, morality and love."52 Resisting the existing authorities through any other means was out of the question.

\section{The Broader Student Body}

The evaluations of Weimar democracy appearing in the Catholic fraternity publications tended to be moderately favorable in comparison

50 Ernst, "Katholizismus und Politik...," 136-142.

51 "Let every person be subordinate to the higher authorities, for there is no authority except from God and those that exist have been established by God. Therefore, whoever resists authority opposes what God has appointed." Ernst, "Katholizismus und Politik...," 136-142.

52 Ernst, "Katholizismus und Politik...," 136-142. 
to the broader German student body. Indeed, most of Germany's college students demonstrated little respect for Weimar's parliamentary institutions, and were not nearly so reticent in arguing that these institutions should be replaced by something else, by means of revolution, if necessary.

Of the immediate post-1918 student cohort, some ninety percent had been veterans of the Great War. ${ }^{53}$ Returning to school in 1919 , these veterans sought to revive the camaraderie experienced at the now quiet front. Their aspirations to achieve a more thoroughly unified and integrated student body were realized in July 1919, when the umbrella organizations of the German Student Committees (AstA) formed the German Student Body (DSt). Representing thirty-eight German and Austrian institutes of higher education, the first DSt student parliament met in the city of Würzburg. Considering its later legacy, it is perhaps surprising that the DSt reflected the incipient democratic impulses of the early republic, when, for the first time, it implemented the principles of universal suffrage and proportional representation in voting for all local student councils. 54

\footnotetext{
53 Geoffrey J. Giles, Students and National Socialism in Germany (Princeton: Princeton University Press, 1985), 16.

${ }^{54}$ Hans Jürgen Rösgen, Die Auflösung der katholischen Studenten Verbände im Dritten Reich, Dortmunder Historische Studien, Bd. 15 (Universitätsverlag Dr. N. Brockmeyer, 1995), 30.
} 
Idealistic in the early months, however, the DSt and the broader German student body that it purported to represent would turn against the democratic and republican principle dramatically. Contemporaries and later historians typically have described university students as among the most anti-republican elements in Germany's population in the years of the interwar period. Hans-Jürgen Rösgen tells us: "In contrast to 1848 , students stood this time against revolution. 1918 was a revolution without students."55 For reasons only partly explained, the reformist zeal of students did not contribute to the revolutionary tide sweeping much of Germany in the months after the war.

Turning their backs on the revolutionary legacy of their predecessors who had struggled against Napoleon and, later Europe's status quo in 1848, much of Germany's post-1918 student cohort lined up firmly behind Germany's counterrevolutionary reaction. Student army veterans from the First World War contributed sizable contingents to the Free Corps. ${ }^{56}$ Some twenty-seven German colleges and universities allowed their students a semester break to participate in the Free Corps and in similarly constituted local volunteer defense groups. Gustav Noske benefited heavily from student participation in

55 Rösgen, 26.

${ }^{56}$ Rösgen, 119. 
local street battles against the Spartacus League. ${ }^{57}$ Similarly, Captain Waldemar Pabst, responsible for murdering Rosa Luxemburg and Karl Liebknecht, deployed student battalions to break strikes inspired by the socialist left. 58 In 1919, students also participated in the bloody counterattack on the short-lived soviet republic in Munich.

To be fair, students may have believed that they were supporting Germany's legitimate constitutional government in these actions against leftist subversives. But, later, in 1920, some 50,000 students lent their support to the Kapp Putsch, which came very close to overthrowing the Weimar Republic altogether. ${ }^{59}$ As will be explained in more detail, students also participated in Hitler's Putsch against the Bavarian government in 1923.

Many historians of the interwar period in Germany believe that the ideological proclivities of most students can be explained, at least partially, by their class origins. The overwhelming majority of students hailed from the sectors of German society that were later most likely to vote for Hitler. (This was not reliably true for Catholics.) According to 1928 statistics, almost a third of Germany's students derived from the

\footnotetext{
57 Gerhard Schäfer, "Studentische Korporationen im Ubbergang zum deutschen Faschismus," 1999 Zeitschrift für Sozialgeschichte des 20. und 21. Jahrhunderts 3 (1988): 111.

58 Michael H. Kater, "The Work Student: A Socio-Economic Phenomenon of Early Weimar Germany," Journal of Contemporary History 10 (1975): 82.

59 Schäfer, 111.
} 
traditionally elite strata of German society, including higher government officials, academics, landowners, entrepreneurs, officers and higher military officials. Another forty percent originated from the newer middle classes, including white collar workers, the nonacademic professions, lower officials and managers. Another twenty-five percent derived from the older, pre-industrial middle classes, including small business owners, independent craftsmen and small landholders. While the working class represented over half of the German population, it could find a meager two percent of its offspring studying at German universities in 1928.60 Among German university students, ninety percent had arrived through the traditional route, the Gymnasien or elite college preparatory schools. ${ }^{61}$

Historians agree that Germany's campus infrastructure after 1918 was wholly inadequate to cope with the issues and dilemmas encountered by students in an ideologically turbulent period. ${ }^{62}$ The early years of the Weimar period witnessed extraordinarily high enrollments at Germany's institutes of higher education. Not

60 Deutsche Hochschulpolitik, cited in Michael Stephen Steinberg, Sabers and Brown Shirts: The German Students' Path to National Socialism (Chicago, 1973), 25. Jarausch has pointed out that the percentage of students born to workers increased from 0.5 percent in 1918 to a still modest three percent by the end of the Republican Period. Konrad H. Jarausch, Deutsche Studenten: 1800-1970 (Frankfurt am Main: Suhrkamp Taschen Verlag, 1989), 134.

61 Schäfer, 114. Steinberg, 23.

62 Michael Stephen Steinberg, Geoffrey Giles, Konrad Jarausch, Gerhard Schäfer, Michael Kater and Jürgen Schwarz, among others. 
surprisingly, the number of students crowding Germany's overstrained lecture halls ballooned. At the University of Berlin, over 1,000 students packed some lectures. Predictably, contact between students and their professors declined. 63

Many contemporaries believed that the universities were poorly suited for the larger numbers of students and ill equipped to serve their needs. Throughout the interwar period, German businesses and private industries complained that universities were training too many students for the traditional academic professions. While refusing to budge from the humanist norm, most universities initially opposed the introduction of newer, applied disciplines. With the exception of the urban universities, Germany's older campuses remained unapologetically (and proudly) rooted in their own anachronism. ${ }^{64}$ Control of the universities remained in the hands of tenured professors, salaried civil servants with the exclusive right to sit on examination boards and serve as rectors. Although the Weimar years witnessed, for the first time in German history, the emergence of professional university administrations, for most of the period, these remained unsettled works in progress. 65

\footnotetext{
63 Steinberg, 13.

64 Steinberg, 16.

65 Steinberg, 13.
} 
As Konrad H. Jarausch tells us, students in the immediate years after World War I could find little support for the new republic in their immediate circles. By 1922, Friedrich Meinecke had taken notice of the overwhelmingly anti-democratic tenor of students in Germany's universities. ${ }^{66}$ Anti-democratic thought left a strong impact on many campus discussion groups. Reared and trained in the imperial years, Germany's aging professoriate at the beginning of the Weimar Republic had not developed well-articulated political views. Some, following the lines of Gustav Stresemann's German People's Party (DVP), grew to be reluctant supporters of the republic, but remained implacably opposed to its more liberal and socialist elements. Other professors leaned further to the right to support the German National People's Party (DNVP), which articulated an exclusionary brand of nationalism and an explicit rejection of the republic. Limited curricular opportunities also handicapped the efforts of students to engage political questions.

Like much of the broader student population, fraternities offered Germany's republic only lukewarm support, at best. Hans Jürgen Rösgen reiterates the common contention that the anti-republican worldview held the upper hand in Germany's fraternities at a time when

${ }^{66}$ Rösgen, 41. 
two-thirds of Germany's students claimed fraternity membership. ${ }^{67}$ By August 1919, Germany's largest fraternity, the DB, had decided to reject the red, black and gold colors of the new republic and, instead, continued to wear the red, white and black colors of Imperial Germany. The DB likewise expressed public support for the now exiled emperor. ${ }^{68}$ Most fraternity members continued to believe that the semiauthoritarian monarchy of Imperial Germany had better served the national cause, even if it had restricted the room for political freedom and expression. 69

By the late 1920s, Germany's student antipathy towards Weimar had intensified. Only twenty-three percent of Prussian students in 1927 expressed their support for the republic, while seventy-five percent had turned against it. ${ }^{70}$ Konrad Jarausch observes that, by the late 1920 s, the combination of generational conflict, economic crisis and national political instability had left students permanently alienated from Weimar. Many students were further embittered by their own professors, who had initially influenced their hostility towards Weimar, but at the same time, had framed their critiques in the same

\footnotetext{
${ }^{67}$ Schäfer, 111. Steinberg, 16, 21. Rösgen, 26.

68 Rösgen, 26.

69 Rösgen, 21-22.

70 Schäfer, 114.
} 
tired language that students now denounced as bankrupt. ${ }^{71}$ Michael Stephen Steinberg agrees that, in the last years of the republic, observers increasingly took notice of a generational gap between students and the academic establishment. The inability of the older generation of university professors and authorities to help students cope with the realities of the 1920s provoked the younger generation into searching for its own solutions to Germany's economic and political crises. By the 1930s, newer students had no memories of Imperial Germany. As Steinberg tells us, many students, by that time, had become convinced partisans of nationalist politics, and harbored nothing but contempt for the academic establishment and university traditions. ${ }^{72}$

\section{Politics and Student Crisis}

It has been argued that the grinding poverty faced by Germany's students during the 1920 s informed and aggravated their hostility towards the republic. After the war, student incomes declined. Many students fell victim to the severe housing shortage plaguing much of the country. ${ }^{73}$ Michael H. Kater tells us that Germany's economic crisis expanded a hitherto relatively unknown category in Germany, the

\footnotetext{
71 Jarausch, 141-149.

72 Steinberg, 8-9.

73 Rösgen, 26.
} 
working student. According to Kater, working students historically had constituted less than ten percent of the German student body. After the end of the Great War, the figure skyrocketed to over thirty percent. Some universities and private businesses did their collaborative best to place students in professional internships. Many other students, however, worked as gas-light attendants, as after hours' staff in museums, night clubs or cafés, as snow shovelers or as shoe-shine boys at rail stations. ${ }^{74}$

Even during Germany's deceptively stable economy of the mid 1920 s, the material condition of students never righted itself. One report from the mid-1920s concluded that approximately one-half of Germany's students lived under minimal subsistence conditions. Near the high-point of Germany's economic recovery in 1927 and 1928, fifteen percent of German students remained without adequate nourishment. Remarkably, the tuberculosis rate for Germany's students, four percent, nearly quadrupled the rate for German workers in the same age group. ${ }^{75}$

Germany's students faced dim prospects for gainful employment after graduation. According to one report appearing in the Unitas journal, some 70,000 university graduates were out of work in 1931,

\footnotetext{
${ }^{74}$ Kater, 72-76..

75 Jarausch, 142.
} 
while those currently enrolled in German universities faced the grim calculus that, while their numbers were rising (enrollment in 1931 was almost twice what it had been in 1925), the job market for the educated was actually contracting. Little wonder that in addition to tuberculosis and malnourishment, German students faced a host of stress related ailments. ${ }^{76}$ Traditionally, Germany's students had thought of themselves as the crème of Germany's society and as the future leaders of Germany. Faced with the same economic insecurities as their middle and upper class parents, many students followed the apparently predictable pattern of rejecting the republic and turned to the nationalist right. ${ }^{77}$

\section{Catholic Fraternities in the Midst of Crisis}

Germany's Catholic fraternities likewise felt vulnerable to the severe economic deprivations afflicting their broader cohort. Through the interwar period, Catholic fraternity brothers were compelled to take out advertisements in the classified sections of their newspapers seeking to secure loans so that they might finish their studies. ${ }^{78}$ Fraternity students hit hard by the economic crisis of the 1920 s also pleaded with fraternity authorities to adjust monthly fraternity dues in

${ }^{76}$ Richard Hebing, Berlin (A.H. Unitas-Sugambria), "Akademikernot - Wirtschaftskrise - Lebensraum," Unitas 72, Nr. 10 (July 1932): 126.

77 Steinberg, 1-5, 18.

${ }^{78}$ Academia/ Schwarzes-Brett, 32 (1919): 148. 
order take into account student financial circumstances. A member of the student council of the fraternity's Cologne chapter noted in July 1921 that conditions for students remained especially difficult in the institutes of higher technical education. These students were hit hard by laboratory and materials fees as well as more expensive textbooks. 79 In the same year, a contributor to the journal of the KV lauded the decision of the Bavarian state parliament to make 2 million marks available to university students. He conceded, however, that this would be "just a drop in the bucket" for those who at the end of the war had "laid down the flag to return to their books."

....in Munich, some 2,000 students had only 150-300 marks per month available. If one only considers the price of room, nourishment and clothes, then one can get a better picture of the misery behind these numbers. What a struggle to exist, what a naked existence!

He continued: "The student is not accustomed to hitting the street to demonstrate and cry for bread." 80

Germany's Catholic fraternity students were likewise victimized by the hyperinflation of 1923. Conditions almost claimed the journal of the KV, which ran a headline in May: "Our Academic Monthly Pages in danger!" To their embarrassment, the editors of the journal in the same

\footnotetext{
79 Von Dipl-Ing. Mais, Ve., Studienrat in Köln, a. Rh., "Die Not der akademischen Jugend," Academia 31, Nr. 3 (25 July 1921): 61-62.

80 Dr. Martin Luible (Sx. Ott. Tt.), "Student in Not" Akadem. Monatsblätter (25 May 1921): 96.
} 
month had to justify the fraternity's decision to raise the semi-annual contributions of alumni and students. They also had to explain why their journal would no longer be distributed to members free of charge. ${ }^{81}$

A year later, the editors of Academia, the newspaper of the CV, described the financial difficulties faced by German-speaking students in the Czechoslovakian capital of Prague. ${ }^{82}$ At that time, Prague housed some 5,000 German students, 3,000 in the universities and 2,000 in the technical schools. The article described overcrowded conditions in the student dormitories. In rooms built for two students, four or five were now living. In some rooms beds had been built one on top of the other for lack of space. In some living spaces, creative remodeling has been deployed to house students where no natural light was available, where even during the day they had to read by lamp. Some veterans said that these conditions reminded them of their army barracks during the war years. Things had gotten so bad, concluded the article, that the

81 1,000 marks for alumni and 500 marks for students Rob Wien (Ru), Jena, "Unsere A.M. in Gefahr!" Akadem. Monatsblätter XXXV (15 May 1923): 33-34. 82 In so doing, the newspaper reflected the broader trend among Catholic and German students more generally to see Germans in Central and Eastern Europe as part of the larger German national community. 
administration had been compelled to turn to the public for contributions of basic living necessities. ${ }^{83}$

In 1919, Bernd Striewe of the Münster chapter of the KV fraternity worried that the precarious state of university education would produce disturbing political reverberations in Germany's student community. In an article entitled "The Bankruptcy of Higher Education in Germany," Striewe remembered that the German scientific and liberal arts had been the envy of the world before the Great War. The alma mater of the German universities likewise had believed with confidence that their university educated sons would go on to successful careers.

This all changed as a result of the war. Life on the front had militarized and schematized the lives of German war veterans. These veterans returned home to demand more practical and applied curricular opportunities from Germany's universities and institutes of higher education. The immediate post-war environment, however, had brought expensive living conditions and poor prospects for educated professionals. According to statistics cited by Striewe, the costs for academic study had doubled or tripled. To make matters worse, at least 40,000 students displaced from Alsace-Lorraine and other lost

83 "Von der Hochschulen, Die Not der deutschen Studenten: Ein Rundgang durch das Studentenheim, Prag, Oktober 1924" Academia 37 (15 December 1924): 94. 
territories strained Germany's already compromised educational resources. ${ }^{84}$

Students at Germany's institutes of higher education faced nothing less than spiritual, academic and cultural bankruptcy, argued Striewe. Striewe asserted that the traditional disciplines in the German universities were suffering from their own "splendid isolation," 85 all the while as the universities limited their enrollments to the privileged classes, and their curricula to the hermetically enclosed disciplines. He would question rhetorically: "which law student, medical student, or engineering student these days takes time out from his course of study to get a hold of a proper general education at the university?"86

Striewe worried, however, that turning in the diametric opposite direction, namely, to an overly technical, practical or pragmatic education would threaten Germany's students with "Americanization," which he equated with a loss of ethical and social responsibility. ${ }^{87}$ On this score, Striewe offered for his authority the testimony of a student colleague currently studying in America. This young Catholic reported that

${ }^{84}$ Bernd Striewe, Münster KV, "Der Bankrott des akademischer Hochschullebens in Deutschland," Akademischer Monatsblätter XXXII, Nr. 1/2 (25 November 1919): 1-2. 85 Rendered in English in the German-language original.

86 Welcher Jurist, Mediziner oder Techniker nimmt such gegenwärtig noch Zeit um sich neben seinem Fachstudium eine gründliche Allgemeinbildung an der Universität zu verschaffen?"

87 Striewe, "Der Bankrott des akademischer Hochschullebens...," 2. 
....here (i.e. in North America) nobody tries to build good character... The more money the individual earns in his life, the more one appreciates him. The catchword in North America is: "he is werth [sic] so many thousand dollars!'88 Being an honest man here usually gets you nowhere. 89

Striewe's extended his criticism of the American education system to American politics. Again, quoting his colleague overseas, Striewe alleged that American politics did not reward capability. Likewise, he believed that the twin principles of connection and corruption ruled the day. ${ }^{90}$ Evidently enamored with the idea that public and private service should be separate, Striewe was appalled to learn that former President William Howard Taft was now serving as a Professor at Yale, and former President Teddy Roosevelt was currently writing for the magazine Outlook. Striewe observed, "Because he has such a big name, he gets a dollar a word. Thereby he makes money, which is the main thing for every Yankee." 91

Americanization, conceded Striewe, had already made inroads into German political and economic life. Should the same thing happen in the university, he worried that

\footnotetext{
${ }^{88}$ Rendered in English and translated into German as "Er ist so viele Tausende wert!") 89 Striewe, "Der Bankrott des akademischer Hochschullebens...," 2.

90 The German language original is undoubtedly more colorful: Bestechlichkeit ist von oben bis unten!

91 Striewe, "Der Bankrott des akademischer Hochschullebens...," 2.
} 
...genuine education will capitulate to meaninglessness. That means nothing else than the destruction of our cultural development with all of its ethical and social demands to capitalism, which with total lack of regard will be free and unhindered from public constraints to enslave the working masses with all its powers. 92

Striewe understood why the war and its consequences had created the demand for a more pragmatic and practical education. He warned, however, that university authorities should not forget the point of higher education, which was to train moral and ethical citizens. To forget this fundamental pedagogical priority in higher education would threaten German culture with Americanization, meaning that

Germany's citizens would simply be subject or object of the marketplace, without principles or ethics. ${ }^{93}$

\section{The DHR Controversy and Catholic Patience with the Republic}

Germany's Catholic fraternity students cautiously supported the Weimar Republic, or at the very least, rejected any course of action that contemplated a revolution of force against its institutions. Catholic fraternity students were beholden to the traditional prohibition against disobedience to secular authority as it had existed since Thomas Aquinas, and probably earlier. To be sure, the Weimar constitution also

\footnotetext{
92 Striewe, "Der Bankrott des akademischer Hochschullebens...," 1-2.

93 Striewe, "Der Bankrott des akademischer Hochschullebens...," 1-2.
} 
accorded with at least some of the tenets of Catholic "state doctrine" as they understood it.

Nonetheless, these students faced the very same pressures and ideas that had motivated most of their colleagues to turn against the republic. Of course, Germany's Catholics did not study in a confessionally enclosed vacuum. They attended the same classes as the broader student body, had access to their newspapers, could read their placards and pamphlets, and almost assuredly attended some of their larger gatherings and social events. That some of the Catholic fraternity students would succumb or nearly succumb to the broader pressures encountered by their colleagues should have come as no surprise. In 1923 and 1924, Catholic loyalty to the republic was severely tested by the actions of the most visibly nationalist and anti-republican student association on Germany's higher education landscape.

In June 1919, former members of the Free German Youth Movement, by then under the Leadership of the Fichte University Association in Berlin, formed a University Ring of the German Type (HDA). ${ }^{94}$ The stated purpose of the Berlin HDA was to unite all students into one consolidated nationalist bloc in order to struggle against the "destructive powers of internationalism of every color." On

\footnotetext{
94 Hochschulring deutscher Art
} 
December 12,1919 , some 4,000 students and other individuals attended the organization's first public assembly at Berlin University. Well known as a passionate German nationalist and a successful propagandist in the previous world war, Protestant Theology Professor Reinhold Seeberg delivered the organization's inaugural address. ${ }^{95}$ General Ludendorff also attended the meeting, which marked his first public appearance since he had fled from Germany to Sweden in November 1918. As Peter Stitz puts it, Ludendorff's appearance made "the political direction of the Berlin HDA very clear."96

Students at other universities soon followed the Berlin HDA's example. At the 1920 student assembly at Göttingen, some thirteen regional university HDA rings and five affiliated groups consolidated to form the national German University Ring (DHR). ${ }^{97}$ With a presence in both Germany and Austria, the DHR expanded to include the dueling fraternities, the nationalist fraternities, and in its early years, even some Catholic fraternities. Walther Schulz, a cofounder of the Berlin

\footnotetext{
95 A Lutheran, Seeberg argued that the Roman Christianity of the Middle Ages was antithetical to the "Germanic soul," and later, along with Paul Althaus, justified the exclusion of Jews from German business and social life as "legitimate anti-Semitism." Julie M. Winter, Luther Bible Research in the Context of Volkish Nationalism in the Twentieth Century. Literature and the Sciences of Man, Vo. 19 (New York: Peter Lang, 1998), 16-31.

96 Peter Stitz, Der CV 1919-1938. Der hochschulpolitische Weg des Cartellverbandes der Katholischen deutschen Studentenverbindungen (CV) vom Ende des. 1 Weltkrieges bis zur Vernichtung durch den Nationalsozialismus (Munich: Herausgegeben von der Gesellschaft für Studentengeschichte und studentisches Brauchtum, e.V., 1970), 41. 97 Deutscher Hochschulring
} 
HDA and a member of the first leadership committee of the DHR, could look on proudly as his movement in less than a year had energized the German student body. 98

The DHR, with its local HDA affiliates, represented a highly controversial presence on Germany's campuses. By most accounts, the organization dominated student politics in the 1920s. The organization established its national offices in Berlin in the same facilities that housed the editorial office of Eduard Stadtler's anti-republican periodical The Conscience. ${ }^{99}$ These offices served as a frequent meeting place for Moeller van den Bruck's circle. 100 Tied to publications like The German People 101 and Young German Voices, 102 the DHR lent its support to the Society for Germans Abroad. Closely aligned with the Young Conservatives, a collection of literary circles, clubs, newspapers and other periodicals, the supporters of the DHR were explicit in their hostility to the Weimar Republic, arguing that its institutions were alien to Germany's national traditions, and unable to secure Germany's national interests. ${ }^{103}$

\footnotetext{
98 Stitz, 41.

99 Das Gewissen

100 Moeller van den Bruck features prominently in Fritz Stern's The Politics of Cultural Despair.

101 Deutsche Volkstum

102 Jungdeutsche Stimmen

103 Steinberg, 7.
} 
Some Catholic students sympathized with the national aspirations of the DHR. As Peter Stitz tells us, at one time, all Munich CV chapters with one exception had belonged to its Munich HDA affiliate. ${ }^{104}$ Many leading CV members were optimistic that the two organizations could rise above confession and politics to support the patriotic cause. In a 1921 issue of Academia, a member of the CV's Kiel chapter applauded the DHR for recognizing the danger faced by the fatherland that threatened the German people "on all sides."105

Other Catholics, however, worried about the DHR's antirepublican fanaticism and warned that the organization might be offering German nationalism as a "substitute religion."106 By 1922, the Unitas fraternity had already rejected out of principle Catholic fraternity membership in the nationwide DHR and its affiliated organizations. ${ }^{107}$ In 1921 , a contributor to its journal denounced the organization as an "obstacle" to the spiritual renewal of the German student body. The article also argued that national chauvinism should be seen as fundamentally distinct from genuine national feeling. For the Catholic, the article continued, the nation is a step, but not the final destination,

\footnotetext{
104 Stitz, 45-46.

105 Rob Thieron, RBo, R-G, Kiel, "C.V. und Hochschulring deutscher Art," Academia 34, Nr 5 (July 25, 1921): 97-97

${ }_{106}$ Ersatzweltanschauung

107 Stitz, 46.
} 
for "him his international religion is the highest value." The article also criticized the openly stated anti-Semitism of the DHR and argued that "When the people turns to God, and not against the Jews, only then will it be saved." 108

In November 1923, some members of the Munich HDA affiliate of the DHR participated in Hitler's Munich Beer Hall Putsch. ${ }^{109}$ The purpose of Hitler's action was not merely to overthrow the Bavarian government, but to use it as a base to overturn the entire Weimar order. This action and its fallout would affect profoundly the DHR's relationship with the Catholic fraternities, and particularly the largest of these, the CV. A front page article in the CV's journal described the "sad events of the eighth and ninth of November," and reported that, as the Putsch unfolded, an impromptu student demonstration had gathered at the University of Munich, and hailed Hitler and Ludendorff as liberators from "Jewish and Jesuit slavery." The demonstrators later marched through Munich's streets hurling insults at Bavarian Minister Gustav von Kahr and Munich Archbishop Michael von Faulhaber. Supposedly the "darling of the nationalist student body" at one time, Kahr was now being denounced by nationalist students as a "traitor and a Jesuit hireling." On November 12, Kleo Pleyer, a Munich HDA

108 "Hochschulring deutscher Art," Unitas 61, \#3 (April 1921): 61-62.
109 Steinberg, 7. 
leader, argued before a student assembly that Germany was facing a "battle of worldview against worldview" between nationalism and both a red and black internationalism (an obvious reference to the Catholic Church). Speakers at the assembly also attacked specifically the Catholic fraternities and again insulted Faulhaber. ${ }^{110}$

The nationalist attacks against Faulhaber were both revealing and instructive. As the President of Bavaria's conference on Catholic Bishops, Faulhaber was not necessarily known to be a friend of the Weimar Republic. ${ }^{111}$ In the first years of the republic, Faulhaber argued that the Weimar government had been installed illegitimately, in the wake of the overthrow of the legally constituted authorities. He also denounced the separation of church and state enshrined in its constitution. In the years before 1923, Faulhaber had called for the restoration of the Wittelsbach dynasty that had abdicated the Bavarian throne in 1918. Faulhaber had witnessed at very close proximity the Munich Soviet and its bloody aftermath in early 1919. Based on the purported lessons from this experience, Faulhaber did not believe that Germany's democracy would provide the best institutional means for ensuring the Church's mission. At the 1922 Catholic Assembly held at

\footnotetext{
110 "Die Novembervorgänge an der Münchener Universität," Academia 36, Nr. 5-8 (December 15, 1923): 17-18. Stitz, 47.

111 As explained in the conclusion, in 1951, Faulhaber ordained Joseph Ratzinger, current Pontiff.
} 
Munich, Faulhaber argued that Weimar had been born with the "mark of Cain" and denounced Germany's Republic as a "perjury and betrayal," in so doing, provoking a well-reported public confrontation with Konrad Adenauer, who was then mayor of Cologne. ${ }^{112}$

In spite of his evident hostility to Weimar, Faulhaber would not condone Hitler's Putsch. As Faulhaber realized, most supporters of the Putsch were no friends of the Catholic Church, and their actions in any event violated the basic Catholic prohibition against revolution. In response, HDA supporters attacked the Cardinal by resorting to the old slur that Germany's Catholics were nationally unreliable. Because Pleyer continued to justify Hitler's Putsch in the local press, the state government banned the HDA's paper (which Pleyer edited) for four weeks and revoked Pleyer's Bavarian residence permit.113 The

112 In response, Adenauer argued that the majority of German Catholics supported democracy, and claimed that "the feelings of the moment should play no decisive role in civic life, even though they in themselves may be worthy of great respect. Robert Krieg, Catholic Theologians in Nazi Germany (New York and London: Continuum, 2004), 25, 87. Rudolf Morsey, Der Untergang des politischen Katholizismus: Die Zentrumspartei zwischen christlichen Selbstverständnis und "Nationaler Erhebung" 1932/33 (Stuttgart and Zürich: Belser Verlag, 1977), 28-29. Heinz Hürten, Kurze Geschichte des deutschen Katholizismus 1800-1960 (Mainz: Mathias-GrünewaldVerlag, 1986), 189.

113 Citizenship and nationality law was one of the many constitutional oddities of Weimar. While citizenship law was determined by the national government, the individual states or Länder conferred the right to reside in their respective jurisdictions. Pleyer originally hailed from Prague, in other words, outside of the German Reich. It is not clear to this author if he had earned German citizenship by 1923 , but in any event, the decision of the Bavarian government to revoke his residence permit effectively deported him from the state. He continued his press offensive from Berlin. 
confrontation over the Putsch precipitated a split in the DHR's Catholic membership, with Martin Spahn and his followers remaining on and most other Catholics leaving. ${ }^{114}$ On January 24, 1924, Munich's Catholic student leaders demanded an apology from the HDA as a prerequisite for further collaboration. The Munich HDA rejected the Catholic "ultimatum," making the break between the two final. A final exodus of $\mathrm{CV}$ and $\mathrm{KV}$ members from the Munich HDA soon followed. ${ }^{115}$

A Unitas alumnus speaking at the $63^{\text {rd }}$ General Assembly of the Catholic Germans at Hanover reported that Munich's Catholic students were "deeply offended" by the November Putsch and its aftermath. ${ }^{116}$ A contributor to the KV journal likewise asserted that Pleyer's attacks against Catholicism were like a wakeup call for Germany's Catholic fraternities, forcing them to close ranks against the HDA. ${ }^{117}$ At its FiftyFourth Annual Convention in Breslau, held in August 1924, the CV issued an official statement in which its leaders conceded that they had misjudged the position of the DHR and its affiliated organizations on the question of patriotism. They had thought that the DHR was a genuinely patriotic student association that stood above party and confession.

\footnotetext{
114 Steinberg, 54-57.

115 Stitz, 47.

116 Hochschulprofessor Dr. A Timpe in Berlin, Vortrag auf dem Festkommers des Unitas-Verbandes anläßlich der 63 Generalversammlung der Katholiken Deutschlands in Hannover, Unitas 64, Nr. 11/12 (September 1924): 163. 117 "Von der Münchner Studentenschaft," Akademischer Monatsblätter Nr. $6 / 7$ (April 10, 1924): 22-23.
} 
But its actions proved otherwise. Specifically, the HDA's decision to support Hitler's Putsch - an act that violated the basic Catholic prohibition against violent insurrection - along with its continual attacks against Catholicism and its organizations (most notably, Faulhaber) pushed the two organizations apart. ${ }^{118}$ The CV ruled out any further collaboration with the DHR. It did allow its individual members to continue their work with the DHR, but only on issues consistent with the CV's religious worldview. As Peter Stitz explained, the organization also renewed its demand that all members remember their moral obligation to work for the fatherland. 119

In the early 1930 s, the issue of loyalty to the republic confronted Catholic fraternities again, this time, in the context of the DSt. By that time, the National Socialist student union had grown to be one of the most visible and active presences on Germany's campuses. (See Chapter 7.) Because the DSt, under the influence of the National Socialists and their allies, had betrayed an even more explicitly hostile position to Germany's existing government, the Unitas, KV and Hochland ${ }^{120}$ fraternities all bolted from the organization in 1931.121 The

118 Jarausch, 125.

119 Stitz, 48.

120 The Center Party's fraternity organization

121 According to information maintained on its official website, Unitas claims that it left as early as 1928. This conflicts with the information found in Rösgen. 
$\mathrm{CV}$ and the Catholic Ring fraternities stayed on. ${ }^{122}$ This decision provoked a Dortmund periodical to criticize the CV: "The public has the right to know why the $\mathrm{CV}$ is marching with the enemies of the state, and not with the other Catholic organizations." A leader of the $\mathrm{CV}$ responded in the same newspaper on May 19, 1931, by arguing that the CV needed to tolerate different opinions within its ranks. ${ }^{123}$ Nonetheless, in a December 1930 meeting of the a national Catholic assembly attended by all the major Catholic fraternal organizations, the $\mathrm{CV}$ joined with the $\mathrm{KV}$ in deciding to prohibit members from holding positions simultaneously in two different fraternities or organizations. This represented an obvious attempt to keep its members out of the NSDStB - the National Socialist student union. ${ }^{124}$ (More on this organization follows in Chapter 7.)

\section{Conclusion}

At the $67^{\text {th }}$ General Assembly of the Unitas fraternity held in Aachen in August of 1930, a speaker reminded his audience that more than two million German soldiers had perished in the Great War,

\footnotetext{
122 Rösgen, 39-41. Hans Peter Bleuel and Ernst Klinnert, Deutsche Studenten auf dem Weg ins Dritte Reich. Ideologien-Programme-Aktionen 1918-1935 (Guterslöh: Sigbert Mohn, 1967), 217.

123 Paulgerhard Gladen, Geschichte der studentischen Korporationsverbände (Würzburg: Becker Verlag, 1981), Vol. II, 154-155.

124 Stitz, 78.
} 
concluded over a decade prior. ${ }^{125}$ Unfortunately, for all their sacrifice, Germany's fallen could not "overcome the overwhelming might of the brutal dictate of Versailles," or the "occupation of German soil by enemy troops." Even with the Rhineland finally free of the hated French occupation, the fatherland now faced global depression and the paralysis of party politics.

As the speaker lamented, the "German people is sick because of the alienation of God and religion. Our people stand... in bitter worry over their daily bread and with no trust in the future." ${ }^{126}$ He continued: "So what should we do?" Whether or not Germany's fallen soldiers would approve of the "the new state form," or "whether we are personally more or less sympathetic to this new state form is unessential to the task ahead of us." Nonetheless, insisted the speaker, Germany must rise again, but this could take place only with "God's help." And God's help would come only "when a Christian Germany embraces the German people." 127

Is it historically worthwhile to consider the Catholic doctrine of state in the context of the Weimar constitution? Could Catholicism and Weimar be reconciled? If not, what role might Catholicism play in

\footnotetext{
125 "Ansprachen und Reden bei der 67 G.V. der Unitas in Aachen," Unitas 70, Nr. 1 (Aug./Sept. 1930), 10.

126 "Ansprachen und Reden bei der 67 G.V. der Unitas in Aachen," 11.

127 "Ansprachen und Reden bei der 67 G.V. der Unitas in Aachen," 11.
} 
establishing a new constitutional order? Dr. Ernst, leaned on Hebrews 11:13-16 to argue that "we are all strangers on the earth," with the only true homeland in Heaven. ${ }^{128}$ Following the older Augustinian tradition, he thereby might have left the impression that temporal questions such as politics were trivial in the context of human salvation, God's grace, and eternity. One anonymous contributor to the Unitas journal insisted that "the highest task of the Church" was not any law or regulation, "but the realization of God in the world through the love of God and men, his children." 129 He went on to write that the Church, "in whose body the community of Christ is embodied," could not be reduced to juridical rights or obligations." But then, the writer continued that "all that is, is through God.... Nothing takes place without his influence." Without Christian belief, he insisted, no community would be possible. ${ }^{130}$

How does one evaluate an existing constitution, or construct a new one, with materials like these? Indeed, the exercise is unavoidably speculative. When Weimar fell in 1933 , Germany got something very different from the "Catholic state form." Nonetheless, understanding

\footnotetext{
128 "But now they desire a better homeland, a heavenly one. Therefore, God is not ashamed to be called their God, for he has prepared a city for them." Ernst, "Katholizismus und Politik," 136-142.

129 "Vom Gemeinschaftsgedanken der katholischen Kirche" Unitas 65, \#9 (June 1925): 103.

130 "Vom Gemeinschaftsgedanken der katholischen Kirche," 103.
} 
how Germany's fraternity writers viewed the Weimar constitution through a Catholic lens says much about how they ultimately addressed the question of German nationalism, and how they first rejected and then accepted National Socialism, as the next chapters will illustrate. 


\title{
Chapter 4
}

\section{Catholic Parties and Fraternity Politics}

\author{
Within Catholicism we are united, that the fatherland \\ cannot be helped with illusions, with promises, with \\ words, but the fatherland can be helped only with deeds, \\ acts, responsibility and the willingness to sacrifice. \\ Chancellor Heinrich Brüning, speaking to the 69th Annual Assembly of German \\ Catholics at Münster, 1930. ${ }^{1}$
}

Before 1914, most of Germany's Catholics had taken for granted their support for the Center Party, their defensive tower that had defended Catholic interests through the Kulturkampf. As Karl-Egon Lönne tells us, through the imperial period (1871-1914), support for the Center Party at the polls became a kind of "plebiscitary expression" of Catholic solidarity. From 1890 until the outbreak of the First World War, with a relatively loyal, stable and reliable constituency, the Center generally held about a quarter of all seats in the national German parliament. Through most of that period, the Center was able to command at times more than 80 percent of the Catholic vote. ${ }^{2}$

\footnotetext{
1 "Die katholische Studentenverbände auf der 69. Generalversammlung der Katholiken Deutschlands in Münster i.W" Academia 43, Nr. 6 (15 October 1930): 17880.

2 Karl-Egon Lönne, "Germany," in Political Catholicism in Europe, 1918-1965, Tom Buchanan and Martin Conway, eds. (Oxford: Clarendon Press, 1996), 157. Remarkably thorough and comprehensive English language treatments of the Center party during the Imperial period are found in the work of Margaret Lavinia Anderson, David Blackbourn, Noel Cary and Lovell Ellen Evans, among others. Rudolf Morsey has long been recognized as the dean of the German language historiography on the subject.
} 
This changed after 1918. Partly, the war had infused Catholics with patriotic energies that many of the older leaders of the Center, still mindful of the Catholic "ghetto" of the past century, could represent only imperfectly. As late as 1930, Reich Minister Dr. Hans Bell, an alumnus of multiple CV fraternity chapters and a close confidant of Heinrich Brüning, continued to embody this cautious mentality. In a contribution to the CV journal in that year, Bell argued that it remained the duty of Germany's Catholic fraternity students to "liberate the Catholic population from the ghetto." "It cannot be denied," Bell continued, referring to efforts to achieve parity for Catholics in Germany's economy, educated professions and civil service, "that our efforts have achieved success, in spite of the obstacles... We however cannot rest, until the sprit of impartiality in the Reich and in the Länder, in the public and private sectors is achieved."3

The calls for parity and liberation from the ghetto, however, did not impress all Catholics. Particularly Germany's younger Catholics had other concerns. By 1918, a formerly unified Catholic milieu had become far more complex than it had been before 1914 , so much so that the very concept rightly had come into question. In the first decades of the twentieth century, the Center itself had lost much of the

\footnotetext{
${ }^{3}$ Reichs Minister Dr. Hans Bell, M.D.R, Gu, BuL, BvBo. "Gedanken über Staat und Parität" Academia 43, Nr. 6 (15. November 1930): 191-192.
} 
cohesiveness and internal discipline that had been its most distinctively resilient feature during the Kulturkampf and its aftermath. The war itself widened profound fissures in the party's leadership. In the opening years of the war, the Center had generally supported the government's war aims. As prospects for German victory eroded, however, party leadership shifted temporarily to the young Matthias Erzberger, who became one of the most notable proponents of the "peace without annexations" platform. This position, along with his complicity in the "shame" of the armistice and Versailles, cost Erzberger his life on August 26, 1921.

In the aftermath of the war, as historian Noel Cary explains, the Center Party's vision wavered. The old line continued to emphasize the traditional stock-in-trade platform of political Catholicism, including support for confessional schools and Catholic parity in the professions and government civil service. The party included these demands in its "Frankfurt Guidelines" developed at the very end of 1918.4 This old guard faced a newer direction advocated by Erzberger who tried to steer the party to the left in order to restore back to the fold some 4 million Catholic workers who had been lost to the SPD. Christian labor leader

\footnotetext{
${ }^{4}$ Noel Cary, The Path to Christian Democracy: German Catholics and the Party System from Windthorst to Adenauer (Cambridge and London: Harvard University Press, 1996), 55-58, 79.
} 
Adam Stegerwald, in turn, represented yet another alternative, by combining German patriotism with demands for inter-confessional cooperation and social and political reform. Stegerwald had already made a name for himself as a maverick before the war by opposing the intrusion of clerical priorities in Catholic labor politics. ${ }^{5}$

As a result of the split between the Independent and Majority Socialist Parties in 1919, the Center was able to align itself with mainstream Socialism in 1919, but not without the defection of some anti-Marxist supporters. The move of the Center during this period, noticeably if slightly, to the left further provoked the emergence of a regional, agrarian Catholic Bavarian People's Party (BVP). ${ }^{6}$ The question of party affiliation for Germany's Catholics became even more complicated when, just six days after the trauma of Erzberger's assassination, Martin Spahn, ${ }^{7}$ who had been openly critical of Erzberger even after his burial, went over to the German National People's Party (DNVP), an explicitly anti-republican organization, and tried to take Stegerwald with him. ${ }^{8}$ Noel Cary very aptly describes the dilemma faced

\footnotetext{
5 Cary, 31.

6 Cary, 55.

7 An excellent biographic portrayal of Martin Spahn is found in Gabriele Clemens, Martin Spahn und der Rechtskatholizismus in der Weimarer Republik (Mainz: MatthiasGrünewald Verlag, 1983).

8 Cary, 96.
} 
by voting Catholics after 1918, by offering Stegerwald's enigmatic example:

A good Catholic, said Stegerwald, could be either conservative or democratic, monarchist or republican, nationalist or particularist: Catholicism provided 'no sufficient universally valid' political orientation. ${ }^{9}$

As we will see in the next chapter, Catholic fraternity students tended very strongly to disagree.

None of this is to say that the Center lost its purpose after 1918. For one thing, in the early months after the war, the party mobilized against Culture Minister Josef Hoffman's plan to end Church subsidies and state support for confessional schools. Because of the influence of the Center on the constitutional negotiations in Weimar at the beginning of 1919, Germany's Christian churches were reaffirmed in public law as corporate entities enjoying full control over their internal affairs. The Weimar Republic likewise continued state payments to churches and guaranteed the role of churches in the army and hospitals. Its constitution also granted unlimited freedom to the religious orders.

Attempts by the Center to secure a guarantee for parental participation in the organization of confessional schools, however, failed

\footnotetext{
${ }^{9}$ Cary, 51.
} 
in the Reichstag in 1925 and again in 1927.10 More seriously, the Weimar Republic never signed a Concordat with the Vatican. This unresolved issue proved to be one of Hitler's most potent negotiating levers against the Pope and Germany's Catholic leadership after 1933. The Vatican was able to achieve separate accords with Bavaria (1924), Prussia (1929) and Baden (1932). ${ }^{11}$

As Cary, Lönne and others tell us, in spite of the Center's active participation in its formative moments, most of Germany's Catholics did not develop any close sense of attachment to the Weimar Republic. While it happened to be, even if for pragmatic reasons, one of the republic's most consistent supporters, the Center gradually lost its hold over voting Catholics through the 1920 s. In the 1870 s, the party had at one time commanded up to 83 percent of the Catholic vote. By the interwar period, this figure had dropped to around 50 percent. ${ }^{12}$ Through the Weimar period, the Center Party, more than any other

\footnotetext{
${ }^{10}$ Specifically, the Center Party wanted to give parents the right to petition their state authorities to establish exclusive Catholic confessional schools in districts where interconfessional schools were otherwise the norm. Opponents to the idea pointed out that Catholic religious instruction was already available to Catholic pupils attending the interconfessional schools. The existing Weimar constitution had never been clear on this matter. Many (but not all) federal states, in any event, favored the exclusive confessional schools. Cary, 113-114.

11 Lönne, 161.

12 Lönne, 60.
} 
major electoral entity, relied on the female vote, ${ }^{13}$ as men were increasingly likely to seek their political homes elsewhere. ${ }^{14}$ According to Lönne, female supporters of the party outnumbered men by 3 to 2.15 While the Center commanded 19.7 percent of the vote in the first elections to the National Assembly in 1919, by the last free elections in November 1932, its support had dropped to 11.9 percent. ${ }^{16}$ In the meantime, with the help of the Catholic Committee headed by Spahn, the nationalist DNVP was able to attract a small but not insignificant 6 to 8 percent of Catholic voters. With its support evidently declining it is a testament to Weimar's constitutional peculiarities that the Center Party led ten of the twenty Weimar cabinets from 1919 to the appointment of Hitler to the Chancellorship on January 20,1933.17 In 1928, the Center selected Ludwig Kaas, a cleric, as the party chair. Lönne, Cary and Paul Waibel all agree that Kaas's election spelled disaster for the party. Kaas expressed little interest in social

\footnotetext{
${ }^{13}$ Women were given the vote in 1920 . Noel Cary writes that this explains why the party's percentage rose from 16.4 percent in 1912 to 19.7 percent in 1919, Cary, 60. 14 Lovell Ellen Evans, The German Center Party: 1870-1933. A Study in Political Catholicism (Carbondale: Southern Illinois University Press, 1981), 243.

15 Lönne, 161.

16 In the 1919 elections, the party had temporarily changed its name to the Christian People's Party. In 1920, the Center and the newly formed Bavarian People's party earned $13.6 \%$ and $4.4 \%$ of the vote, respectively, or a cumulative total of $18 \%$. In the November 1932 elections, the BVP earned 3.1\%. Since the Center's percentage in the same election stood at 11.9, this meant that the Catholic parties together polled $15 \%$. This statistic might give pause to the prevailing paradigm that saw Catholic support for Catholic parties declining, at least significantly. Statistics cited in Eberhard Kolb, The Weimar Republic (London and New York: Routledge, 1988), 194-195.

17 Lönne, 161.
} 
issues at a time when Catholic workers were as likely as ever to vote SPD. His attempt to strengthen the confessional character of the Center Party weakened its flexibility at precisely the moment when it needed all the allies it could find after National Socialism gained momentum starting in 1930. According to Lönne, German Catholicism "missed a precious opportunity to identify with the ideals and practical political potential of the new democratic state." In the meantime, in Lönne's words, the Center Party "failed to create any clear political image for itself and lost much of its former political dynamism."18 Kaas, by then living and working in Rome, played a key role in convincing the Center's leaders to dissolve their party as a condition of Hitler's Concordat with the Papacy in July 1933. ${ }^{19}$

\section{Catholic Fraternities after World War I}

After World War I, Catholics entered German universities in record numbers. Catholic enrollment tended to be the highest in places of traditional Catholic demographic strength. Ten years after the war's conclusion, Catholic enrollment remained minimal in much of Germany's Protestant north, ranging from five to twelve percent in Leipzig, Dresden, Hamburg, Berlin and Königsberg. At universities

\footnotetext{
18 Lönne, 165-167.

19 Guenter Lewy, The Catholic Church and Nazi Germany (Da Capo Press, 1964, 2000 edition used here), 78 .
} 
located in nearly evenly divided southern and western regions, Catholic enrollment remained disproportionately low. Through the Weimar period, Catholic enrollment stood at slightly under twenty percent in Tübingen and Stuttgart, while it exceeded slightly over twenty-five percent at Heidelberg and Frankfurt. In the Catholic populated eastern enclave around Breslau, Catholic enrollment wavered between forty and fifty percent, as it did in the predominantly Catholic cities of Munich and Freiburg. Catholic enrollment reached its highest numbers in the heavily Catholic Rhineland, exceeding the fifty percent mark in Bonn, Cologne, Münster and Aachen. It also exceeded fifty percent in Bavarian Würzburg. ${ }^{20}$

Catholic fraternity membership also expanded during the Weimar period. Between 1919 and 1931, Unitas almost tripled its membership from approximately 900 to 2,400 active members. According to Peter Stitz, Catholics flocked to Unitas, in part, because it was the most explicitly connected to the Catholic Church hierarchy and because it had encouraged a long tradition of socially progressive politics. ${ }^{21}$ In the same period, the KV enjoyed similar growth, expanding from 2,000 to

20 Deutsche Hochschulstatistik (1929), cited from Michael Stephen Steinberg, Sabers and Brown Shirts: The German Students' Path to National Socialism (Chicago, 1973), 28.

21 Peter Stitz, Der CV 1919-1938. Der hochschulpolitische Weg des Cartellverbandes der Katholischen deutschen Studentenverbindungen (CV) vom Ende des. 1 Weltkrieges bis zur Vernichtung durch den Nationalsozialismus (Munich: Herausgegeben von der Gesellschaft für Studentengeschichte und studentisches Brauchtum, e.V., 1970), 77. 
5,600 active members. The CV remained the largest of the three, growing from 4,400 to 10,000 active members. ${ }^{22}$ In 1931 , the CV trailed only the DB $(11,600)$ among all German fraternity organizations. ${ }^{23}$ Throughout the period, the $\mathrm{CV}$, the $\mathrm{KV}$ and the Unitas fraternity also maintained strong cross-border ties with local German Catholic chapters in Danzig, Switzerland, Austria, Czechoslovakia and Romania. ${ }^{24}$

In 1921, the Erlanger Fraternities Agreement ${ }^{25}$ recognized the nationalist, dueling and confessional fraternities as corporate entities with equal rights on Germany's campuses. Still, in the immediate years after World War I, Catholics studying at Germany's universities continued to face hostility from their nationalist cohorts. In their publications and in their public slogans, many nationalist and dueling students continued to aim at Catholics their traditional historical

\footnotetext{
22 In 1930, the number of alumni in the CV, the KV and the UV were, respectively, $16,080,12,746$ and 3,384. Hans Jürgen Rösgen, Die Auflösung der katholischen Studenten Verbände im Dritten Reich, Dortmunder Historische Studien, Bd. 15 (Universitätsverlag Dr. N. Brockmeyer, 1995), 180.

${ }^{23}$ All statistics cited in Rösgen, 179. In 1930, there were a total of 78,917 active fraternity students in Germany and another 170,497 fraternity alumni. The German Waffenring, a national umbrella organization of nationalist fraternities, dueling associations and student corps, represented over half of these, including 48,965 active members and another 118,571 alumni. Rösgen, 181-182.

24 Stitz, 43. In the same year, the CV had a total of 123 chapters (90 in Germany), the KV had 104 chapters (93 in Germany) and the UV had 61 chapters (56 in Germany). Rösgen, 190.

${ }^{25}$ Erlanger Verbändeabkommen
} 
taunts, including the familiar: "Without Judah, without Rome, we (re)build old Germany's throne."26

In the immediate months and years following the end of World War I, the national Catholic fraternity organizations entertained calls from influential Catholic quarters to coordinate more vigorously their policies and positions. Prominent Catholic politicians like Carl Sonnenschein believed that Catholic confessional identity could play an integrative role among the three (and, later, four) national organizations. Sonnenschein took the lead in promoting a more sustained collaboration within the broader Catholic student organizational framework. ${ }^{27}$ In June of 1919 , he managed to bring together representatives from the major national Catholic university organizations. His purpose was to consolidate Catholic students on all social, economic and university-related questions. The conference produced mixed results. At the fifty-seventh general assembly of Catholic fraternity organizations, held just a month later, representatives could agree to cooperate only on social activities. ${ }^{28}$

\footnotetext{
26 Ohne Juda, ohne Rom, bauen wir altdeutschlands Thron. Hans Peter Bleuel and Ernst Klinnert, Deutsche Studenten auf dem Weg ins Dritte Reich. IdeologienProgramme-Aktionen 1918-1935 (Gutserslöh: Sigbert Mohn, 1967), 240. 27 Jürgen Schwarz, Studenten in der Weimarer Republik: die deutsche Studentenschaft in der Zeit von 1918 bis 1923 und ihre Stellung zur Politik (Berlin: Duncker \& Humblot, 1971), 130.

${ }^{28}$ Schwarz, 140. Stitz, 61.
} 
Eight Catholic fraternity and other organizations did agree in September of 1919 at Frankfurt to create the Working Community of Catholic German Student Unions (AG). For a time, the Catholic AG included Catholic splinter organizations like the South-German Cartel of Catholic Student Unions (SKV), ${ }^{29}$ the Academic Union of St. Boniface and the Secretariat of Social Student Work (SSS). The latter two organizations left the body in 1923. In 1926, the KV, the CV and Unitas met in Würzburg and decided to extend the life of the AG for the time being. Otherwise, the organization rarely produced substantive agreements. ${ }^{30}$ As early as 1920 , the spiritual advisor of the CV, Erhard Schlund, reflected the prevailing consensus when he insisted that the individual national fraternal organizations remain at the "core and the foundation" of Catholic German student life. ${ }^{31}$

As was the case with their non-Catholic counterparts, Catholic fraternities after World War I confronted the curious problem of a split generation gap. Many Catholic fraternity members had seen their studies interrupted by four long years of war and had re-enrolled in early 1919 as hardened veterans, with experiences far beyond their

\footnotetext{
29 In 1920 the KV absorbed the SKV

30 Schwarz, 140. Stitz, 77. Karl Hoeber, Handbuch für die Mitglieder des Verbandes der kath. Studentenvereine Deutschlands (Cologne, 1921), 61.

${ }^{31}$ P. Erhard Schlund, "Zur Frage der Arbeitsgemeinschaft der katholischen deutschen Studentenverbände," Academia 33 (20. July 1920): 61.
} 
years. At fraternity functions, they sometimes sat next to far younger students who had arrived straight from the college preparatory schools. As an exasperated Ernst Mayer of the KV explained in October 1919:

Never before was a fox stall ${ }^{32}$ such mishmash: nineteen year old Mulus sits next to a twenty-seven year old man. That their thoughts do not always move in the same direction goes without saying. ${ }^{33}$

The conflicting perspectives identified by Mayer almost certainly complicated public discussion concerning the purpose and goal of Catholic fraternities after 1918. After World War I, many Catholics believed that their fraternities needed to reconstitute their traditional images. They complained that past Catholic insularity had produced political indifference, making it difficult for organizational Catholicism to channel its innate demographic strengths into positive national achievements. ${ }^{34}$ Catholics fraternity students argued that they needed to demonstrate a more assertive willingness to engage in the hard work of national rebuilding and renewal.

Within a contested and confused atmosphere, fraternity alumni like Nikolaus Ehlen of the CV rejected calls to end Catholic exclusivity. In a series of articles appearing in the fraternity monthly newspaper

\footnotetext{
32 the German words for fox and pledge are identical

33 Ernst Mayer, "Das erste Jahr nach dem Kriege," Akademische Monatsblätter (15 October 1919): 128.

34 Stitz, 67.
} 
and in general circulation Catholic periodicals like Hochland, Ehlen demanded that Catholic fraternities return to their roots and carry the banner of pure Catholicism. ${ }^{35}$ Ehlen's criticism of the Catholic fraternity movement went much further, when he also alleged that Catholic fraternities were sacrificing the Catholic religion for naked financial gain. To back this potentially incendiary claim, Ehlen alleged that fraternities were tolerating dues paying members, who were less than diligent in fulfilling their religious obligations. Accusing his fraternity brethren of practicing a kind of "kitsch Catholicism," Ehlen sternly reminded his readers that "one cannot serve both God and mammon." While he found fault with all of the major Catholic fraternal organizations, Ehlen reserved especially harsh criticism for his own CV, claiming that it had become an "unholy fees collecting house."36

Ehlen's frequent writings appearing in the years after World War I provoked a barrage of hostile counterattacks in the Catholic student press. ${ }^{37}$ While not mentioning Ehlen directly by name, Emil Rath of the CV dismissed the criticisms against his fraternity, written "even by members from the CV," as "one-sided exaggerations... unfounded and

35 Stitz, 68.

${ }^{36}$ Gottfremdes Tollhaus. J. Vincke, "Lotsenruse," Unitas 5 (August 1921): 129. Dr. Nikolaus Ehlen, "Vom wirtschaftlichen Wollen der neuen Jugend," Academia 35 (MayJune 1922): 2. Emil Rath, "Der korrekte Fuchs," Academia 34 (Nov-December 1921): 206.

37 Vincke, "Lotsenruse," 129. Ehlen, "Vom wirtschaftlichen Wollen der neuen Jugend," 2. Rath, "Der korrekte Fuchs," 206. 
unjustified...."38 In an article laden with evocative metaphors, appearing in the August 1921 edition of Unitas, J. Vincke flatly rejected Ehlen's accusation that his Unitas fraternity had overlooked the presence of non-practicing Catholics in its ranks:

Not only do you thunder, but you also hurl lightning. That has its virtue. But do you also have the power to take back the disastrous effects of your lightening bolts? We want to be completely open with you and say what we ourselves know. At every conference, taking place three times a year, we take special care to call to account every fraternity brother over the Catholic practice. And, at every annual General Assembly, our fraternity representative makes clear and unambiguous in his official report that all members took Holy Communion....The protocols of the General Assembly provide proof of the adamant seriousness with which these questions are handled by our active members and alumni. ${ }^{39}$

A pamphlet authored by CV member, Adolph Leo Nettmann, entitled "The Correct Pledge: Advice for All Color-Wearing Students," provoked similarly acrimonious denunciations in Catholic student press circles. Nettmann's controversial pamphlet explained to fraternity pledges how to behave properly

1) in pubs and in Church, 2) at beer countertops and cafes, 3) on the streets and in public transit, 4) at the university, 5) when confronted with the duel, 6) at sport, 7) by wind and inclement weather and 8) in society and in theater. ${ }^{40}$

\footnotetext{
38 Rath, "Der korrekte Fuchs," 206.

39 Vincke, "Lotsenruse," 129.

${ }^{40}$ Rath, "Der korrekte Fuchs," 207.
} 
Critics writing for Academia complained that Nettmann had encouraged fraternity brothers to conform to the pre-World War I dandyish stereotype that the Catholic fraternities were now seeking to overcome. These critics also charged that Nettmann had limited his focus to the seemingly inane and trivial aspects of fraternity life, at precisely the moment when many of Germany's students faced the acute psychological and material stresses of post-war reintegration. These returning veterans needed to be reminded that fraternities could provide more fulfilling and meaningful experiences. ${ }^{41}$

\section{The Question of Fraternity Politics}

Rejecting Ehlen and for different reasons Nettmann, many Catholic student leaders called on their fraternities to play more assertive and constructive roles in national political life. They argued that a more explicit engagement with national politics would catalyze a more dynamic fraternity image. Before the Weimar period, Catholic fraternities, with the possible exception of Unitas, had navigated a delicate policy of official political neutrality. ${ }^{42}$ But, in the aftermath of World War I, many influential Catholic fraternity voices called for a "new

\footnotetext{
41 Stitz, 67.

${ }^{42}$ Wilhelm Kosch, "Die Erneuerungsbewegung in der katholischen deutschen Studentenschaft," Das Neue Reich VIII, \#32 (1926): 661.
} 
orientation" a "new system" and a "jump to politics."43 Many members of the $\mathrm{CV}$ wanted to modify a provision of the fraternity constitution that had prohibited the national fraternity leadership from taking official political positions.

Fraternity historian Norbert Sklorz offers the following statistic: at the end of the Great War, approximately 60 percent of Germany's students belonged to the traditional fraternities but only 5 percent of these belonged to political parties. ${ }^{44}$ According to Sklorz, if students engaged in the question of party membership at all, they did so usually on theoretical grounds only. In the Weimar period, this situation changed dramatically. The revolution set loose a wave of general politicization, which seized all traditional student fraternities. ${ }^{45}$ This was also true for the Catholic fraternities. An article appearing in the December 15, 1918 edition of the CV's monthly newspaper, Academia, asserted: "Membership in a Catholic fraternity can no longer be an impediment, but must be a motivation to participate constructively in the political struggles of the day." Later, the article admonished:

Catholicism in Germany and in the world forward! The $\mathrm{CV}$ in Catholic Germany and German Austria forward!

\footnotetext{
43 Norbert Sklorz, Die politische Haltung der Academia 1918-1935 (Würzburg: Veröfftentlichung des Archivvereins der Markomannia, 1980), 9.

44 Sklorz, fn. 5.

45 Sklorz, 9.
} 
There is no turning back. New times require the courage for new deeds. ${ }^{46}$

The call to the Catholic fraternities to take more explicit political stands provoked one of the most serious controversies in Catholic student circles in the immediate years after World War I. The CV's influential alumni worried that a more explicit role in German national politics would lead to unforeseeable consequences for the Catholic fraternities. They also tried to restrain student political activism. ${ }^{47}$ Many members of the KV also expressed their hesitation to endorse a more assertive orientation towards politics. As Ernst Mayer suggested, some Catholic students were not eager to dedicate themselves to a more serious engagement with politics or to overturn the more exclusively student-oriented life that had characterized the Catholic fraternities before the war. As Mayer explained:

What will the future bring? After four years of military duty, will one still be interested in formal fraternity life? Should we orient ourselves anew? Only to the last question were we quickly of one opinion: an emphatic no. We have and have had no reason for a new orientation. On the contrary, as a goal, we stand for working our way back to life before the war....

\footnotetext{
46 Aug. Ruß, "Und wir?" Academia 31 (December 15, 1918): 178-179.

47 Bleuel and Klinnert, 62.
} 
Mayer continued: "We want to live and be happy as in the old student days. He who wants that comes to us. And he who does not want that goes his own way." 48

In 1922, at its Fifty-Third Annual Convention in Bonn, the CV leadership affirmed the organization's traditional stand to stay out of national party politics. ${ }^{49}$ The KV leadership also kept its distance from party politics. ${ }^{50}$ The Unitas leadership did lend its official support to Germany's new republic. The fraternity likewise followed its pre-World War I tradition of encouraging social activism from individual members. But otherwise, Unitas avoided making explicit, individually binding political pronouncements.

Through the 1920 s, calls in Catholic fraternity circles to construct a more assertive and definitive position on German national politics would not go away. Continued disappointment with the politically ambivalent positions taken by the three major existing fraternities motivated some Catholic students to join more explicitly nationalist organizations like the German University Ring (DHR). The belief that Catholic students had a more important role to play in German national politics also produced a fourth national Catholic

\footnotetext{
48 Mayer, "Das erste Jahr nach dem Kriege," 128.

49 Stitz, 44-45.

50 San-Rat. Dr. Hersting, "Verband-Politik," Akademische Monatsblätter 37 (October 1924): 52.
} 
fraternity organization, the Ring of Catholic German Fraternities

(RKDB), or the Ring, as its members called it, which formally withdrew from Unitas on October 9, 1924.51

At the most basic level, the fraternity members who formed the Ring wanted to wear colors, a practice that had been rejected by Unitas. But, perhaps more importantly, the Ring's leadership elected to call the organization a Burschenschaft, a title which, since its first usage immediately after the Napoleonic occupation, had nearly always been reserved by the nationalist fraternities, and specifically, the DB. Historically, the Catholic fraternity organizations had preferred the more politically neutral titles Verbindung or Verein.52 By electing to use the title of Burschenschaft, the Ring stated its clear intention to follow the nationalist fraternity tradition, at a time when these fraternities were openly hostile to the Weimar Republic. ${ }^{53}$

More broadly, the founders of the Ring argued that the three existing Catholic fraternities were not doing nearly enough to help

\footnotetext{
51 Ring katholischer deutscher Burschenschaften, originally formed from the Gothia Berlin, Franco-Borussia Würzburg, Sigfridia Bonn and Ripuaria Aachen chapters. 52 Langenscheidt's New College German Dictionary (1995) offers "students' fraternity" as an English equivalent to both Verbindung and Burschenschaft. Verein is more typically translated as "club" or "society." As explained earlier, the chapters of the color wearing CV called themselves Verbindungen. The chapters of the non-color wearing $\mathrm{KV}$ and Unitas called themselves Vereine, but otherwise followed fraternal forms of organization and practice.

53 Hawel Hub, cand. phil., Wien, "Vom Verstehen unserer Grundsätze," Der Ring 3 (Nebelung/November 1927): 91-92.
} 
Germany rebuild its shattered economy, break free from the crippling shackles of the Treaty of Versailles or reassert itself as a dominant national power. As Josef Zanders, editor of the Ring's periodical, explained immediately after the fraternity's founding, if defending ...our fatherland, our people, and above all, our youth and students of German and Christian character and morality means making available all of our powers of spirit, then we do not want to stand back. We want to be comrades in arms, shock troops ${ }^{54}$ and leaders. The fatherland will find in us its core troops...armed with the courage of weatherhardened men...55

As Wilhelm Kosch, a prominent contributor to Ring publications put it more bluntly in 1926, "the people require deeds and, especially, fundamental clarity." Kosch also asserted that his fraternity organization wished to construct a serviceable Christian nationalist vision for Germany. ${ }^{56}$

The emergence of the Ring signified a reaction against the liberal and socialist currents that its leaders had alleged were infecting Germany's academic community more profoundly than any other segment of German society. ${ }^{57}$ Many members of the Ring took an openly hostile position towards Germany's postwar republic. Members of the Ring also criticized the Catholic Center Party, in part, because it

\footnotetext{
54 Vorkämpfer

55 Dr. Josef Zanders, "Zum Geleit," Der Ring 1 (November 1924): 2.

56 Kosch, "Die Erneuerungsbewegung...," 661.

57 Kosch, "Die Erneuerungsbewegung...," 661.
} 
had served as a coalition partner with various combinations of socialists and moderate democrats in Germany's parliamentary government. 58 After its founding, the Ring officially joined the $\mathrm{CV}$, the $\mathrm{KV}$ and the Unitas fraternity within the Catholic Working Community (AG). While Ring membership trailed the other three national Catholic organizations (681 active members and 489 alumni in 1930), 59 the fraternity maintained its own publishing organ that produced a polished newspaper (The Ring) on a monthly or semi-monthly basis. Kosch also contributed to a general circulation Catholic periodical, The New Reich. Among the four major nationwide Catholic fraternal organizations, the Ring stood out as the most outspoken proponent of greater German nationalism. As Hans Berger, a Ring member, would clarify in 1929:

The RKDB departed from the position of full political neutrality not to engage in party politics, but to insert itself consciously in the national political struggle of the present. As its fundamental principle it demands love of fraternity and the greater German peoples and state community as the highest temporal virtue. This more activist orientation separates it from the other Catholic student organizations and establishes for it a special position. ${ }^{60}$ (Bold in the original.)

${ }^{58}$ Kosch, "Die Erneuerungsbewegung...," 661.

59 Rösgen, 181.

60 Hans Berger, “Korporation, Hochschule und Akademikerschaft," Der Ring 5 (Feb/March, 1929): 107. 
Although it refused to endorse any specific political party, the Ring often enjoyed friendly relations with the nationalist German student organizations that would gain the upper hand in German student life in the years before Adolf Hitler's national triumph. Members of the Ring were known frequently to side with the nationalist organizations in their renewed and often violent confrontations with Catholic fraternity students in the early 1930 s. ${ }^{61}$

\section{Catholic Fraternities and the Question of the Center Party}

Germany's Catholic fraternity leaders recognized that national politics after 1918 would be determined by parties. But Catholic students could not come to agreement on whether their confessional identity should in any way determine their party affiliation. The debate over party affiliation for Catholics was joined in the October, 1919 issue of Academia. Fraternity member J. Ganis reminded his reader that the new political realities had brought new laws and new obligations. The recently instituted electoral law of the Weimar Constitution had made every 20 year old German an active political participant. For this reason, Catholic fraternity members (many of whom were well past the age of 20 due to wartime service) would have to confront the questions: "To which party should I belong? For which party should I vote?" On

\footnotetext{
61 Paulgerhard Gladen, Geschichte der studentischen Korporationsverbände (Würzburg: Becker Verlag, 1981), Vol II, 154-155. Rösgen, 58-59.
} 
the question of membership with the Social Democrats (usual coalition partner of the Center) Ganis responded to a previous March 15 article by asserting that Catholics should remain distant from any socialist party. "We are an organization of Catholic academics. Socialism of any shade is irreconcilable with Catholicism." Ganis quoted the German Socialist leader August Bebel to ironic (if authoritative) effect: "Christianity and socialism stand vis-à-vis each other like fire and water." 62 (More will be said about the Catholic rejection of German socialism in the next chapter.)

In the same article, $V$. von Lemke turned to the question of Center Party membership, a topic left untouched by Ganis. Evocatively, von Lemke noted that Germany's new electoral laws put senior members of the fraternity in a delicate position of responsibility vis-à-vis younger pledges. He wrote: "It is clear, that the 20-year-old Mulus or Fox in his first semester will ask his senior: 'hey, who should I vote for?' What kind of answer should we give him?" Lemke responded that a student fraternity, which seeks to influence its members so strongly in spiritual matters, also had the duty to give its youngest members political guidance. Continuing, von Lemke reasoned that, if the CV brought together its members on the grounds of religion, and namely,

62 "Katholische Student und Politik," Academia 32, Nr. 5/6 (15. Sept/Oct. 1919): 152154. 
the Catholic religion, as the first principle of its colors, then it also had the duty to ensure that its members participate in German elections to promote Catholicism. ${ }^{63}$ Von Lemke then asked rhetorically: would anyone in the $\mathrm{CV}$ really believe that any other political party would be as loyal and supportive of the legal rights of the Catholic Church as had been the Center Party? Would it be possible for anyone from an alternate perspective, for instance, a monarchist, republican, democrat, or conservative, to recommend something better than the Center Party? He concluded, because the CV was built on the principle of Catholicism, it was necessary for the fraternity to throw its support behind the party that purportedly embodied the spirit and virtue of this principle best. 64

Turning to the question of leadership, undoubtedly a rhetorically powerful theme to his intended audience, von Lemke insisted that one joined a fraternity in order to represent the Catholic community. Since the "overwhelming majority" 65 of the Catholic population belonged to the Center Party, it seemed self evident that a Catholic academic could serve his community best by joining the Center. Lemke went on to offer practical recommendations on how the fraternity at the local level could

\footnotetext{
63 "Wenn nur der CV seine Mitglieder auf Grund des Katholizismus zusammenschliest, wenn er Religion, versteht sich katholische Religion, als erstes Prinzip auf seine Fahne geschrieben hat, dann hat er auch die Pflicht, dafür zu sorgen, das seine Mitglieder ihre Wahlpflicht in einer Weise erfüllen, die dem katholizismus förderlich ist." 64 "Katholische Student und Politik," 152-154.

${ }^{65}$ As we know, this was not exactly true anymore.
} 
contribute to Center politics. For one thing, local fraternity chapters should organize regular political discussion meetings to be attended by "a good speaker" from the Center. These speakers should be both "leading" personalities and rank-in-file party activists. Von Lemke also called on his brothers to work outside of the fraternity by visiting party functions and gaining a clearer picture of party life and party business. Members might also report back formally to the fraternity on party activities. Von Lemke recognized that some fraternity members might join other parties, and insofar as possible, they should be tolerated, but only if their parties did not contradict the interests of Catholicism. ${ }^{66}$ Not all Center supporters within the Catholic fraternities were so transparent in their call to proselytize on behalf of the supposed political standard-bearer of German Catholicism. Some worried that campaigning openly for the Center might backfire by driving some other-thinking Catholics away from their own fraternities. In consideration of these concerns, the editors of the journal of the KV felt compelled to apologize for a transparently political article by clarifying that political neutrality "requires only that the fraternity is not officially connected with politics. It is not thereby prohibited for a member of the

\footnotetext{
66 "Katholische Student und Politik," 152-154.
} 
fraternity once in a while to address a political theme." ${ }^{\prime 67}$ Being the transparent standard bearer of political Catholicism might also reignite the confessional hostilities that had plagued German campus life before 1914.

In March 1920, Professor Max Buchner responded to a previous article from a student by conceding that Germany's post-Revolutionary realties had left many young Catholics searching for a compass. In spite of the long line of Center politicians that had hailed from his fraternity, Buchner reiterated the position prevalent before 1918 that his fraternity should stay out of party politics. ${ }^{68}$ Although it was true, as Buchner noted, that the majority of the Catholic population belonged to the Center, or in Bavaria, the BVP, these were not exclusively confessional parties in the sense that confessional issues alone did not determine their platforms. Buchner also reminded his reader that the purpose of the CV was to raise its brothers as "good Catholics" and "good Germans," and to endow them with the maturity, wisdom and discretion to follow their own political paths. Any attempt to insist on a specific political position or platform to which all members must

67 Editor's note to an article from Dr. Hermann Port, Wiesbaden, "Römischer Katholizismus und politische Form," Akademischer Monatsblätter 37, \#8 (May 1925): 302-305.

68 Univ. Prof. Dr. Max Buchner Lb., "CV und Politik," Academia 32, Nr. 11 (25 March 1920): 319-320. 
subscribe would compromise inevitably the principle of friendship upon which the fraternity was based. 69

A speaker at the October $192450^{\text {th }}$ General Assembly of the KV at Hanover maintained that the fraternity stood neither right, nor monarchical, nor "middle of the road," nor republican, but only German and Catholic. Dr. Hersting recited the history of the fraternity, now 80 years old, and reminded his listeners that Ludwig Windthorst, Georg von Hertling, Carl Bachem, Karl Trimborn, Adolf Gröber, Felix Porsch, Ernst Lieber, Franz Hitze, Konstantin Fehrenbach and Wilhelm Marx, a veritable who's who of the Catholic Center Party, had all been Catholic fraternity members. Hersting also reminded his reader of the civic liabilities that fraternity membership had entailed historically. As he remembered, a certain colleague of his in 1897 had prohibited his son from joining a Catholic fraternity because he feared that it would bar his progress in the civil service or the army. Hersting continued to believe that, whether in the countryside, in trade, in industry or the free professions "we are the citizens of a second class...." He believed that the "inferiority complex" was felt especially among university educated Catholics and that their first and foremost priority, regardless of their

${ }^{69}$ Buchner, "CV und Politik," 319-320. 
political affiliation, should be to combat their disadvantaged status in German society. ${ }^{70}$

Hersting went on to acknowledge a widening gulf between fraternity alumni and current student members in his time. Students especially were unhappy with the legacy of the lost war, the war guilt clause, and its supposed insult to German national pride. Quoting Detlev von Lilienkron, who had written in an earlier article "better dead than a slave," Hersting admonished his reader to come to terms with reality. Hersting argued that only hard work and service "not utopian slogans" could save the "beloved fatherland." Conceding frankly that many young Catholics had turned to the nationalist parties, Hersting asserted that the nationalist right, representing interests inimical to Catholicism, would be only too happy to exploit the decision of Catholics to turn away from their own banner. ${ }^{71}$

Hersting's arguments did not go unchallenged. Writing for the Unitas publication, Dr. Klenbolte, an attorney and Unitas alum from Hanover, agreed that it was right to carry on the struggle against Catholic inferiority. Klenbolte countered, however, that anyone who had joined the fraternity simply for career advancement had done so for the wrong reason and had thereby betrayed his religion in the process.

70 Hersting, "Verband-Politik," 55.

${ }^{71}$ Hersting, "Verband-Politik," 52-58. 
Many Catholics, reminded Klenbolte, had already turned away from the Center. This was true not only for the young and inexperienced, those allegedly vulnerable to nationalist sloganeering, but also for senior Catholic leaders like Martin Spahn, the son of a Center politician who now worked for the DNVP. ${ }^{72}$ These were not just naïve party activists, he asserted, blindly distributing party pamphlets and placards. Their motivations, even when turning from the Center, were sincere and wellinformed..$^{73}$

Klenbolte likewise sympathized with fraternity members who had expressed bitterness that fraternity publications had been used to criticize political positions that seemed to turn away from the Center. Klenbolte himself had felt affronted personally when a fraternity alumnus and administrator of a local Center organization tried to convince the audience at a general Catholic assembly to vote for the Center. He accused the Center itself of meddling in student affairs by opposing publicly the DHR. Acknowledging that Catholic fraternities had contributed a great number of leading Center politicians, Klenbolte countered that Catholic fraternity brothers need not play the unthinking role of "young soldiers of the Center." This had been the

\footnotetext{
72 Rechtsanwalt Klenbolte (A.H.), "Parteinpolitiker - Hände weg vom Kartellverband!" Unitas 37, \#8 (May 1925), 305-309.

73 Klenbolte, "Parteinpolitiker...," 305-309.
} 
accusation of the Academic Kulturkampf, which young Catholics had every right to reject then, as they did at the present moment. True, it would be wrong of the fraternity leadership to obligate young Catholics to affirm the platforms of the German Nationalists or the Democrats (there was, of course, no danger of this happening), but this should also apply to the Center. The only thing that could be expected of young Catholics was not neutrality, but an affirmation of their Catholic persuasion..$^{74}$

What was the point of the disagreement between Klenbolte and Hersting? Klenbolte alleged that Hersting was using the "neutrality" position as a smokescreen, when what he really wished was to keep Catholics where they had been before 1914, firmly in the orbit of the Center. In other words, neutrality would be the only acceptable fraternity position, but only if neutrality meant support where it had traditionally been situated, the Catholic Center. Realities after 1918, insisted Klenbolte, when young Catholics were looking for new avenues through which to express their loyalty to the German nation, were far more complicated. 75

\footnotetext{
${ }^{74}$ Klenbolte, "Parteinpolitiker...," 305-309.

75 Klenbolte, "Parteinpolitiker...," 305-309.
} 


\section{Beyond Parties}

In 1928, Aloys Hermens of the Unitas fraternity complained that the "organizations of the left and right can do little" for the ideals of Germany's Catholic students. ${ }^{76}$ The confusion of party politics occasionally pushed some Catholic to consider politics beyond the seemingly mundane questions of party affiliation. In a lecture given at Munich in November 1928, Hans Bremser, a law student and member of the Rheno-Pfaria Munich chapter of the newly formed Catholic Ring fraternity, argued that the 1918 revolution had created a vacuum in German society that threatened to destroy "the old idea of the spiritual man." "We are living in a period of transition" he declared, at the end of an epoch that had become old and rotten because it was missing the spiritual feeling that alone made the individual young. In its time, Bremser argued, the idea of humanism had been overrun by rationalism, liberalism by capitalism, and democracy by socialism. ${ }^{77}$

The last decades of the nineteenth and early twentieth century ended in world war and its violent consequence that did not limit themselves to Europe, but had spread throughout the whole world. According to Bremser, the German people were living in the middle of

76 Aloys Hermens, "Der 30. November und seine Folgen," Unitas 68 (March/April 1928): 83-86

77 Bremser Hans, stud. Jur. (Rheno-Pfaria, München), “Krise der Gegenwart," Der Ring 4, 89 (November 1928): 80. 
these outbreaks. ${ }^{78}$ In the face of this impending catastrophe, continued Bremser, all the usual categories of thought propagated by the supposedly progressive and revolutionary leaders of the nineteenth and twentieth centuries were hopelessly outdated and had no meaning. The general crisis of parliamentarianism and democracy had proved the futility of talk. Scientific and academic study had lost their general sense of humanity and has become hopelessly specialized. He clarified: "Instead of thinking macroscopically, one thinks microscopically." In an evident reference to Julius Langbehn, a late nineteenth century standard bearer of the politics of cultural despair ${ }^{79}$ Bremser asserted “...the seeds of a violent rupture are scattered throughout the entire world." He believed that in the near future, contemporary Germans would witness a violent and irreversibly transformative event. 80

Bremser went on to compare Europe to the Roman Empire, "with its repulsive racial mixture." 81 He concluded that, like Rome, contemporary Germany was held together by nothing more than "blood and iron." Here, he meant that different state interests were unified not by culture, but by the force of law and arms, both empty concepts. But

78 Bremser, "Krise der Gegenwart...," 80.

79 Fritz Stern's words, not Bremser's.

80 Bremser, "Krise der Gegenwart...," 80.

81 The presence of racism, at least as constructed here, was usually subdued in Catholic fraternity writing. This topic will be addressed at greater length in Chapters 6 and 7. 
history would repeat itself. Rome had fallen, and in the chaos, would give birth to Christianity, and the universalistic, theocratic culture of the Middle Ages. In these times, the inner freedom of the Christian individual had been greater than it would be in the subsequent era of so-called democracy and liberalism. With the rupture of 1789 , religion was once again separated from culture. As Bremser explained, "God was burned, the human was idolized." And then, the bourgeoisie emerged, and with it, democracy, signifying the victory of a great herd mentality. ${ }^{82}$ The influence of Friedrich Nietzsche and the Russian philosopher, Nikolai Berdyaev, is obvious. In the early 1920s, Berdyaev lived in Berlin, before moving to Paris.

The results of these developments, according to Bremser, had been the destruction of culture, the triumph of technical civilization, and the emergence of soulless national states that embodied the crassest egoism and materialism, and sanctified an internal war of all against all. In opposition to the bourgeois national state emerged the equally repugnant doctrine of socialism. ${ }^{83}$ This ideology rightly rejected the formal sovereignty of the people that had been the fantasy of democratic liberalism. But it offered as a substitute the material

82 Bremser, "Krise der Gegenwart...," 80.

83 Here, Bremser was actually referring to Soviet Bolshevism, not mainstream European socialism. He did not appear to take the latter seriously. 
sovereignty of an ascendant class. Opined Bremser: "Socialism is once again a form of theocracy, but in the negative sense." In Bremser's mind, neutrality in the conflict between socialism and the bourgeoisie would be impossible. ${ }^{84}$

It would be extremely difficult to situate Bremser on any political map of Germany in 1928. Few of the vote-getting parties, save some elements of Hitler's then insignificant National Socialists, articulated their positions in such apocalyptic, anti-systemic overtones. Just a year prior, a contributor to The Ring recognized the national disarray described by Bremser, but placed his faith in the "national hero" and symbol of the German people, President Hindenburg. ${ }^{85}$ In the meantime, most parties occupied themselves with more mundane matters: the continued debate over the confessional content of German education, taxes, unemployment benefits, or foreign relations, including the seemingly endless complaints about Versailles and war reparations. Some on the far edges of the spectrum, like the Communists and the National Socialists, called into question the constitutional legitimacy of the Weimar republic. But, their alternatives - dictatorship, whether on

84 Bremser, "Krise der Gegenwart...," 79-81.

85 "Hindenburg" Der Ring 3 (Nebelung 1927): 89. 
the left or the right - were not exactly new to the political vocabulary of the contemporary reading public.

Bremser signified a trend among especially younger Germans to argue that Germany's existing constitution was wholly inadequate to cope with the crisis that Germany would soon face, if it were not facing the crisis already. Stated another way, a vacuum in German politics was opening that the existing parties and their worldviews were unable to fill. That Bremser, a practicing Catholic and a Catholic fraternity member, would in 1928 situate himself in this vacuum was exceptional, but Bremser was in fact far from being alone.

\section{Conclusion}

On April 15, 1930, Academia proclaimed proudly that the "all revered" President Hindenburg had in the moment of the "greatest parliamentary difficulties" called on the leader of the Center Party, Dr. Heinrich Brüning, to serve as Reich Chancellor. ${ }^{86}$ For the fourth time in the last 13 years, an alumnus of the $\mathrm{CV}$ had stood at the top of the Reich government.

The irony behind the superficial triumph for German Catholicism could not be more apparent. As part of Germany's military duumvirate that also included Ludendorff, Hindenburg had called on Germany's

86 "Reichskanzler Dr. Heinrich Brüning Bd!" Academia 42, Nr. 12 (15 April 1930): 367 
first Catholic Chancellor, the venerable Graf von Hertling, in the last full year of the Great War. At that moment, faced with an unraveling German social fabric, Hindenburg and Ludendorff were prepared to dispense with the pretense of parliamentary government and move towards full military dictatorship.

Thirteen years later, Germany faced yet another crisis, this time, global depression and complete paralysis in its parliament. Now, the very same Hindenburg stood ready to call on another CV alum, again, as he and a small circle of advisors considered ways of moving Germany more firmly into authoritarian hands.

Six months after his appointment, Chancellor Brüning addressed an assembly of German student organizations on the occasion of the 69th General Assembly of Catholic Germans in Münster. Brüning himself was well aware of the crisis faced by the German people, namely the "unending difficulties, economic, spiritual and social emergencies." "We have times behind us, catastrophes," he declared.

We have survived these times in the belief for a better future. We have overcome these times, because the Catholic population, the Catholic academic youth and the Catholic youth in such times, have done their duty.

Brüning asserted that Germany's Catholics must combine the enthusiasm of the youth with the wisdom of the older generation. 
Within Catholicism we are united, that the fatherland cannot be helped with illusions, with promises, with words, but the fatherland can be helped only with deeds, acts, responsibility and the willingness to sacrifice. ${ }^{87}$

In fact, Brüning's optimistic claim that Germany's Catholics remained united behind the teetering system which he served at that very moment could not have been any further from the truth. For the past ten years, Catholic fraternity students and their alumni, while nominally supportive of the republic, had debated about everything from the value of democracy to party affiliation. But, these same Catholics were also arguing about something deeper. If the Weimar constitution, parliamentary politics and the traditional parties (including their own Center Party) could not embody their aspirations as both Germans and Catholics, the next question had to be, what solution could?

87 "Die katholische Studentenverbände auf der 69. Generalversammlung der Katholiken Deutschlands in Münster i.W" Academia 43, Nr. 6 (15 October 1930): 17880 . 


\section{Chapter 5}

\section{The Ethos of Catholic Community}

For the Catholic, his religion is like the air that he breathes and the eyes through which he sees. In this time of individualism and liberalism, one has become accustomed to seeing religion as a category of human life and human culture, next to art, science and politics. And Catholicism would be seen as just a kind of genus or species of religion. On the contrary, if religion is not an absolute world value, then it is no longer a religion. He who thinks otherwise is not thinking Catholic! Academia, October 15, $1927^{1}$

Insofar as it can be described as a worldview that speaks to politics or to other matters, Catholicism aims for consistency and harmony. Or at least so German Catholic fraternity writers in the 1920s and early 1930s believed. Dr. Ernst wrote for Academia in 1927 that a Catholic "can judge the world, but he cannot judge his religion. The basis of his religion is eternal and untouchable." Catholic religion, he reasoned, is true only when it unites theory and practice, belief and life. "Religion and life" he continued "cannot be separated." What is virtue in religion is likewise virtue in politics. What is evil in religion is evil in politics. The Catholic religion, he instructed "tolerates no double reality or double morality."2

1 Dr. L. Ernst, "Katholizismus und Politik: Grundsätzliche Erwagungen," Academia 40, Nr. 6 (October 15, 1927): 136-137.

2 Ernst, "Katholizismus und Politik...," 136. 
Writing on behalf of the Union of Catholic Female Student Organizations of Germany, ${ }^{3}$ Josefine Kremser reflected the anxieties of the post-1918 period, when she wrote that, "wherever we look," Catholic students faced outbreaks of conflict in thought, in word and in deeds. "Our little ship struggles against threatening waves - where is the way, where is the goal?" She agreed with her cohort in arguing that Catholics needed a directional star to guide them through the ideological confusion that was seemingly synonymous with Weimar politics. Kremser believed that the Catholic Church and its worldview could provide precisely such guidance. ${ }^{4}$

The ideas on politics emanating from the Catholic fraternities and their journals do not lend themselves easily to systematic summary. From the previous discussion, we know that Catholics approached Germany's new constitutional structure in 1919 with reserved ambivalence. We also know, however, that Catholics considered it both their patriotic and their religious duty to obey their legitimately constituted authorities. Catholic fraternity writers therefore rejected

\footnotetext{
${ }^{3}$ First introduced in the Introduction and Chapter 1 . This organization, along with the remaining Catholic fraternities, was outlawed by order of the SS and the German Police in 1938. See Chapter 7.

4 "... das kirckliche Lehramt und die kath. Wissenschaft haben uns Wegweiser aufgestellet auch für das politische Leben." Josefine Kremser, "Katholische Politik Streiflichter," Die katholische Studentinin: Organ des verbandes der kath. StudentinenVereine Deutschlands 9 (July 1922): 6-11.
} 
talk of overthrowing the existing government by force. Following the advice of St. Thomas, they agreed that even bad laws are allowed by God in order to test the patience of good individuals and punish the wicked ones. They likewise agreed that resisting evil with violence produces only more severe evils. ${ }^{5}$ Nonetheless, Catholic writers through the 1920 s and early 1930 s rejected the constitutional structure that emerged from Weimar in early 1919 on a number of fundamental grounds.

\section{The Social Contract Theory and the Nature of the State}

First, Catholic writers identified the new Weimar entity as the heir to the social contract state of Hobbes, Locke and Rousseau. In their understanding, political liberalism would have it that the state resulted from a fictitious contract consummated among and by finite individuals. Following Aristotle by way of Aquinas, Catholic fraternity writers rejected the idea that individuals could be abstracted as discreet entities. Stated another way, it was nonsense to suggest, as had the British and French liberals (supposedly), that individuals existed historically prior to the political community. An alumnus of the KV fraternity wrote:

\footnotetext{
${ }^{5}$ Dino Bigongiari's introduction to The Political Ideas of St. Thomas Aquinas (New York:
} The Free Press, 1953, 1997 paperback edition used here), xxxvi. 
The state is not just the sum of individuals, nor just a cumulative or multiplied sum of private welfares. A natural state integrates all orders and classes as a whole community, as an organism. ${ }^{6}$

Concerning the origins of the state, Josefine Kremser denied that people "lived stateless in prehistory" and then "united on opportunistic" grounds. ${ }^{7}$ That the social contract theory contradicted Christian principles, she argued, Pope Leo XIII had established in his encyclical Diuturnum of 1881 . This document had denied the idea that civil society derived its origins from the free consent of human beings. Leo argued that the human community is not something that human beings "chose" to form historically, or even metaphorically. The community, according to Leo, was rather established by God as part of the natural order. The social contract theory, Leo continued, had no authority in conferring political power on the state. Only by recognizing that power emanated from "God as its august and most sacred source," Leo concluded, will governments have "all those ornaments and guarantees" necessary to rule effectively. Following Leo's logic, Kremser would comment: "That the individuals live in the state is a requirement of

\footnotetext{
${ }^{6}$ Dr. V. Tischleder, Münster, i.W., "Der katholische Staatsgedanke als Echo der ursprüngliche gefundenen katholischen Wesenmitte," Akadem. Monatsblätter 44, \#1 (October 1931): 120-126.

7 Kremser, "Katholische Politik - Streflichter," 6-11.
} 
nature, or more accurately, the creator of nature, God."8 A Unitas contributor agreed that the state represented "a natural necessity for the maintenance of the social organization and the promotion of the common good." He likewise contended that the state was "moral," "God-given" and the "prime necessity of the human social organism."9 Franz Müller, addressing the sixty-fifth general assembly of the Unitas Fraternity in Duisburg in 1928, asserted that "the state is not a product of real or fictitious agreements, but is the consummation of the essentially social nature of people." 10 Writing for the Unitas journal four years later, Müller added that "in no case does the community represent an each-for-himself, 11 " in which individuals participate on the

\footnotetext{
${ }^{8}$ Kremser, "Katholische Politik - Streflichter," 12. This document reads: "Those who believe civil society to have risen from the free consent of men, looking for the origin of its authority from the same source, say that each individual has given up something of his right, and that voluntarily every person has put himself into the power of the one man in whose person the whole of those rights has been centered. But it is a great error not to see, what is manifest, that men, as they are not a nomad race, have been created, without their own free will, for a natural community of life. It is plain, moreover, that the pact which they allege is openly a falsehood and a fiction, and that it has no authority to confer on political power such great force, dignity, and firmness as the safety of the State and the common good of the citizens require. Then only will the government have all those ornaments and guarantees, when it is understood to emanate from God as its august and most sacred source." 9 Dr. Timpe, "Volksdeutsche Erziehung des Akademikers," Unitas 67 (October/November 1926): 1.

${ }^{10}$ Referat, gehalten auf der 65 G.V. des Unitas-Verbandes zu Duisburg 1928 von Dr. Franz Müller, Karlsruhe (A.H. Deutschritter-Unitas), Unitas 86, Nr. 10 (July 1928): $150-152$.

${ }^{11}$ Für-sich-Seiendes
} 
terms of their choosing. ${ }^{12}$ State and community, Müller insisted, cannot be separated. When people exist together, as they must, out of the aggregate emerges a unity and something qualitatively new. ${ }^{13}$ Citing Romano Guardini, Müller argued that the human person had two essential features or essences: unity-objective and individual-subjective. By participating in the "mystical body of the community," the individual achieves a unique spiritual synergism. Concluding that in the pure identity of God, both the "I" and "We" are represented, Müller held that the mystery of the Trinity embodied the "metaphysics of community." "Insofar as we are in God's image, we also in ourselves form a picture of this original community." 14

\section{Competition or Cooperation}

Assuming the state to be part of God's natural order, Catholic writers believed that the state should unite communities far more organically, intimately and interdependently than allowed by the liberal trajectory. For that reason, Catholic writers rejected the idea, supposedly affirmed by the Weimar constitution, that politics was to be understood as the competitive mediation of individual or special

\footnotetext{
12 Dr. Franz Müller, Köln (A.H. Deutschritter-Unitas), "Vom Wesen des Politischen und Sozialen. Aus Anlaß einer Begriffsbestimung der Sozialpolitik, Unitas 73, Nr. 1 (October 1932): 1-7.

13 "Nebeneinander ein Miteinander, aus der Vielheit (Aggregat) eine Einheit, also ein qualitative Neues.

14 Müller, "Vom Wesen des Politischen...," 1-7.
} 
interests. This is not to say that Catholic writers rejected the idea of parties or parliamentary democracy, per se, as the preceding chapters should have demonstrated. They did believe, however, that the Weimar constitution needed to do a better job of organizing Germany society cooperatively and collaboratively, not competitively. For this very reason, Dr. Anton Böhm, addressing an assembly of Austrian Catholic students 15 in 1932 , asserted that the Christian "corporate doctrine held the key to creating a genuine people's state of the future."16

Dr. Eugen Kogon, who from 1939 to 1945 would be incarcerated in the Buchenwald concentration camp, ${ }^{17}$ affirmed this idea at the same assembly. Kogon added that a corporative constitutional structure should contemplate a parliament that would no longer be organized along the lines of Germany's competitive party system. Instead, a parliament should allow different interests in German society to manage

\footnotetext{
15 Katholische Deutsche Hochschulerschaft Österreichs. 16 Walter Ternik, M-D, "Der christliche Volkstaat," Academia 45, Nr. 7 (Nov. 15, 1932): 190-191.

17 This is the same Kogon who memorialized his experiences at Buchenwald in Der S.S. Staat. Guenter Lewy and Peter Stitz also confirm that Kogon for a time belonged to the Kreuz und Adler (Cross and Eagle) association of Catholic conservatives. This organization also included Franz von Papen. Guenter Lewy, The Catholic Church and Nazi Germany (Da Capo Press, 1964, 2000 edition used here), 46, 355. Peter Stitz, Der C.V. 1919-1938. Der hochschulpolitische Weg des Cartellverbandes der katholischen deutschen Studentenverbindungen (CV) vom Ende des 1 . Weltkrieges bis zur Vernichtung durch den Nationalsozialismus (Munich: Herausgegeben von der Gesellschaft für Studentengeschichte und studentisches Brauchtum e.V., 1970), 86, $117,403$.
} 
the economy cooperatively. ${ }^{18}$ Because they believed that a Christian society must base itself on a cooperative ethic, in which each component of society (labor, capital, agriculture and the professional middle classes) understood its role in the productive order, Catholic writers typically denounced parties that openly represented specific or class interests. For this reason, they criticized the Social Democratic party, frequent coalition partners of the Catholic Center Party in Germany's parliament, even if there was much they found favorable in its progressive social welfare platform.

Their obvious ambivalence over Weimar democracy and parliamentary politics in truth reflected a deeper sense of unease among politically engaged Catholics. Almost unwittingly, Catholics reaffirmed a fundamental component of Marxism, when they suggested that Germany's politics reflected deeper structural features explained by the nature of the German economy, namely, capitalism and market competition. Following a trajectory that stretched deep into the $1800 \mathrm{~s}$, these commentators believed that market competition violated God's natural order that demanded a cooperative and organic society.

Again, the influence of St. Thomas made itself deeply felt. In his 1983 survey on the relationship between Catholicism and German

\footnotetext{
18 Ternik, "Der christliche Volkstaat," 190-191.
} 
Social Democracy, Paul Waibel tells us that the Angelic Doctor inspired progressive Catholic activists like Bishop Ketteler (1811-1877), Franz Hitze (1851-1921) and Karl von Vogelsang (1816-1890), all of whom to varying degrees rejected unregulated capitalist competition. Wanting a kind of democratized version of the medieval guild system, these figures were especially influential in organizing a Catholic labor movement so as to preempt Marxism during the last decades of the nineteenth century. The belief that a morally regulated economy might preserve private property while mitigating the worst ills of industrial society continued to influence Catholic labor on down to Adam Stegerwald (1874-1945), Chair of the German Trade Union Federation. ${ }^{19}$

The Catholic Church hierarchy likewise criticized the competitive nature of the German economy and society. But here, Waibel suggests that the Church may have been driven by self-interest, as much as its own theology. In his words:

It was felt, that if the Church could provide a system which relieved the miseries caused by laissez faire capitalism, while at the same time putting an end to the uncertainties of liberal-democratic politics, it would defeat the threat to its existence as an institution and preserve the dominant position of Christian philosophy as the basis of society. ${ }^{20}$

\footnotetext{
19 Paul Waibel, Politics of Accommodation: German Social Democracy and the Catholic Church, 1945-1959 (Frankfurt am Main and Bern: Peter Lang, 1983), 13-19.

20 Waibel, 11.
} 
More broadly, the Catholic hierarchy judged both capitalism and its nemesis, socialism as guilty of essentially the same sin. Both elevated the material interest of individuals over spiritual and ethical needs. In 1891, Pope Leo XIII had denounced both capitalism and socialism on these grounds in Rerum Novarum. He likewise denounced industry for its inhuman treatment of workers, holding that the "condition of the working classes was a moral problem." Rerum Novarum similarly determined that the individual did not possess an unlimited right to property, particularly insofar as this right conflicted with the priority of the family and the harmonious order of society. Free competition, insisted Leo, must be subordinated to a just economic order based on the principles of justice and love. Benedict XV affirmed Rerum Novarum in his encyclical Bonum Sane in 1920.21

To summarize Waibel's portrayal, leading Catholic commentators at the turn of the twentieth century called for a communitarian Christian society. In so doing, they rejected social contract theory, unregulated capitalism, parliamentarianism, liberal democracy and individualism. Stegerwald might have encapsulated these ideas best when he defined the Christian state as a "fundamental renunciation" of the ideas which arose from the Enlightenment. To Stegerwald and his

\footnotetext{
21 Waibel, 13-19.
} 
followers, the state should be seen as a "community in destiny and life." He would conclude that "the state exists for us in a completely different sphere from that of the individual."22

The leading Catholic fraternity writers in the 1920 s affirmed similarly this rejection of capitalist individualism and competition. Contributing to the journal of the KV in 1925, Hermann Port contrasted two conflicting ideals. He defined one as the "economic," which saw no ethical value beyond the utilitarian fulfillment of material need. $\mathrm{He}$ defined the other, antithetical ideal as the "juridical," which sought to provide the community with direction and a norm of existence. "The history of the centuries," he lamented, witnessed everywhere the victory of the economic ideal over the juridical ideal. Of the ideal figures of the Middle Ages - the pope, emperor, monk, knight and merchant - only the pope remained. In Germany's contemporary climate, "the citizen more and more" had become the "servant of blind productive processes," all the while as the demons of capitalism destroyed a people's community "naturally" opposed to its economy of exploitation. ${ }^{23}$

In Port's way of thinking, "no king or parliament" truly embodied the German nation. The king, as everyone knew, was gone. Parliament

\footnotetext{
22 Waibel, 13-19.

${ }^{23}$ Dr. Hermann Port, Wiesbaden, "Römischer Katholizismus und politische Form," Akademischer Monatsblätter 37, \#8 (May 1925): 302-305.
} 
itself had become simply a body of delegates representing the economic machine: "the only reality, without God, without state, and without moral constraints, which regulates itself." Capitalism had pushed European society to the point, warned Port, where people were forced to choose between extremes: dictatorship or anarchy, theocracy or "Satanocracy." The individual, in the meantime, "wavers like a speck of dust between existence and non-existence.... He has a choice between God and nothing." 24

Reflecting the social demography of Germany's Catholic population, writers for the fraternity journals sympathized very heavily with the lower middle classes. They believed these to be the most endangered by the encroachment of German capitalism. Writing for Academia, Alfred Diehl defined the middle class as the entity in German society that worked with "its brains and its hands," rather than with money. More precisely, he distinguished the traditional middle classes that encompassed the artisan trades and commerce from the "new middle class," of industrial bosses, officials and financiers. By artisan, Diehl meant one who through his own direction processed "raw materials" or partially fabricated materials into finished products. Ordinarily, a true artisan trade would require a long period of training.

\footnotetext{
24 Port, "Römischer Katholizismus und politische Form," 302-305.
} 
According to Diehl, both artisans and small merchants (those whose duty it is to navigate the traffic of goods from producer to user) belonged to the middle class because they had in common independence and ownership. ${ }^{25}$

Diehl urged the middle classes to resist any constitution that threatened to destroy their economic independence, a danger he believed both capitalism and socialism posed. Deconstructing the notion that capitalism stood for individual initiative, Diehl retorted that bonds holders and financiers in the advanced stages of capitalism deprived the individual entrepreneur of any real decision-making power. ${ }^{26}$

Dr. Stracke, a Catholic jurist, shared Diehl's sympathy for the middle classes. Writing for Academia in 1921, Stracke urged Germany's middle classes to stand against the cartelization of big industry and the division of the economy on purely capitalist lines. He likewise believed that the traditional middle classes stood much closer to Germany's workers in disposition and ethics. "Only in the medium and small firms" argued Stracke, was the worker "still a personality, because he is a collaborator, and co-entrepreneur." In big industry, on

25 Alfred Diehl, Ve., "Der Gewerbliche Mittelstand im Kampfe gegen Kapitalismus und Sozialismus, Eine Zeitbetrachtung," Academia 33, Nr. 2 (June 21, 1920): 31-33.

${ }^{26}$ Diehl, "Der Gewerbliche Mittelstand ..., 31-33. 
the other hand, the worker was just a cog in the machine. More broadly, Stracke believed that the preservation and promotion of the small business ethic contributed to German family life. He observed that in small enterprises, family members like the wife played a meaningful and productive role. One "need only think" Stracke reminded his reader, that in wartime it was up to the wives to run the small family firms while the husbands fought on the battlefield. Small companies also played a meaningful educational role for children, who supposedly were able to see "first-hand the efforts of their father and mother to earn their daily bread." Officials and industrial managers offered a stark contrast in the sense that their children saw "their parents only after they have come home from work."27

Turning to the Weimar constitution, Stracke criticized the state as being limited to oversight and police powers. He insisted that the purely formal nature of the Weimar state must be changed to achieve a true national community ${ }^{28}$ representing the various occupational orders of society. He urged young Germans at the universities and higher technical institutes to investigate more seriously the economic and

\footnotetext{
27 Von Referendar Dr. iur Stracke, Rh, Volkswirt R.D.V., Ehndikus des Reichschutzverbandes für Handel und Gewerbe, Hauptgeschäftstelle Braunschweig, "Die Beruf Stände von Handel, Handwerk and Gewerbe und der Wiederaufbau Deutschlands," Academia 34, Nr. 7/8 (Nov-Dec 1921): 201-202.

28 Obrigkeitsstaat... Polizeistaat... Volksgemeinschaft
} 
political ramifications of the danger posed to the middle classes by big capitalism, and its nemesis, socialism. But he complained bitterly that "our scholarship has treated the independent middle class of trade and occupation like a poor stepchild."29

Writing for Unitas, Catholic political economist Aloys Hermans more broadly contrasted capitalism with the earlier productive arrangement that had known its heyday in the Christian Middle Ages, when "the spirit of the Church" was united with the German countryside, "German blood" and the traditional occupations. In the intervening centuries, free competition had destroyed the old harmony of interests. Through the catalytic aid of industrial machine power, capitalism had triumphed over all. Sounding eerily like Marx and Lenin, Hermens wrote that the capitalist economy now found itself in the world's last village. ${ }^{30}$

Through its history, wrote Hermens, capitalism had encountered opposition from both the old artisan class and the new proletariat. Its theory of balance between supply and demand in an anarchistic economy could not account for the periodic crises and cycles of overproduction. Nor could classical economics theory justify or explain

29 Stracke, "Die Beruf Stände...," 201-202.

30 Diplomvolkswirt Aloys Hermens, (Unitas-Rhenania), "Kritik des Kapitalismus," Unitas 69, Nr. 7 (April 1929): 89-90. 
the practice whereby the despotic owners of Germany's cartels controlled and manipulated prices. These practices, argued Hermens, had made a mockery of the principle of free competition. Here, Hermens relied on Schumpeter's theories on the divergences between production and consumption that characterize advanced capitalist societies. Even if he did not speak to Lenin's work on imperialism specifically, Hermens repeated the old claim that imperialism was seen as a way of absorbing surplus goods ${ }^{31}$ and generating the surplus capital on which the capitalist depended for profit. ${ }^{32}$

Hermens' analysis of capitalism yielded interesting distinctions between the European and North American settings. In the European, and especially German context, asserted Hermens, there still existed a genuine proletariat in the sense of a hereditary earning class, which formed an integrated constituent of capitalist society. In the United States, partially because of its colonial legacy, a proletariat was absent. ${ }^{33}$ The United States, argued Hermens, was sociologically a purely capitalist land, while in old Europe elements of the capitalist and former feudalist system existed side by side, even if nervously. To Hermens and to other Catholic commentators, this was not necessarily

\footnotetext{
31 but not surplus capital, as Lenin theorized

32 Hermens, "Kritik des Kapitalismus," 89-90.

${ }^{33}$ Hermens, "Kritik des Kapitalismus," 89-90.
} 
a favorable comparison, as far as the United States was concerned. True, the North American economy offered historically unprecedented opportunities for upward mobility. Some seventy percent of the directors in U.S. firms, estimated Hermens, hailed from the working class. ${ }^{34}$ But, capitalist wealth could be lost as quickly as it could be won, as he bemoaned to his reader (resorting to English): "Three generations from overalls to overalls!"

\section{Community and Communism}

As Paul Waibel reminds us, Catholic authorities remained implacably hostile to Germany's Marxist parties until after World War II. Through the Weimar period, Catholics continued to hold that socialism and Catholicism were essentially incompatible. Even in the early years of the Federal Republic, Waibel informs us that politicians from the CDU and CSU continued to use anti-Marxism as an effective means of rallying Catholics against the SPD. ${ }^{35}$

There were of course notable exceptions, including Heinrich Merten's League of Catholic Socialists ${ }^{36}$ and Vitus Heller's Christian Social Party, ${ }^{37}$ known as the Reich Party after 1920. Other attempts to formulate a serviceable Christian Socialism after 1918 were found in

\footnotetext{
${ }^{34}$ His estimate may not be altogether reliable.

35 Waibel, 35-37.

${ }^{36}$ Bund der katholischen Sozialisten

${ }^{37}$ Christlich-Soziale Partei
} 
the Christian trade unions, led by Wilhelm Hohoff. Germany also had its Catholic pacifist groups, including the Peace League of German Catholics, a circle that gravitated around the Rhine-Main People's Newspaper ${ }^{38}$ in Frankfurt. The circle included Walter Dirks of the Republic Union, the publication German Republic, and the left wing of Catholic youth movement. Only a minority of Catholics, however, joined the SPD. Mertens' League of Catholic Socialists produced "The Red Page of Catholic Socialists"39 albeit with Social Democratic financing. But in Waibel's authoritative estimation, these entities were largely unable to lure Catholics to socialism during the Weimar period. They did shape individuals like Dirks, who would later play important roles in post- 1945 German politics. ${ }^{40}$

The most obvious and self-evident source of disagreement in the 1920s between German Catholicism and Germany's Marxist parties remained religion. Both the SPD and KPD were officially atheist. Even if the former, in its position as Germany's leading party during the early constitutional period, refrained from attacking religion per se, it believed that freedom of religion, or freedom not to be religious at all, depended on the elimination of Germany's churches from official public life.

\footnotetext{
${ }^{38}$ Rhein-Mainische Volkszeitung

${ }^{39}$ Das rote Blatt der katholischen Sozialisten

40 Waibel, 51-53.
} 
As explained in the preceding chapter, the $\mathrm{CV}$ and other fraternities rejected member participation in the SPD. In 1919, J. Ganis of the CV equated socialism with atheism, and went on to catalogue the various anti-Church measures pursued by the SPD through its history. Ganis continued by arguing that in the "cultural" debates held on the eleventh of March in the Weimar constitutional proceedings, the proposed Socialist program over marriage, family, education and property flatly contradicted "the beliefs and ethical doctrines of our holy church." Calling on the authority of the Pope and the German Bishops (and specifically a pastoral letter of January 8, 1919), Ganis argued that "one cannot be a convinced believer of socialism and at the same time an upstanding Christian. Either or. The contradiction and struggle between socialism and Christianity and Church is irreconcilable." Turning to Scripture, Ganis continued: "He who is not with me is against me. He who does not belong to my flock is scattered." 41 Did the Catholics and Socialists share similar social goals, as some Catholic politicians like Heinrich Brauns had long believed? Ganis responded with a resounding no. Socialism, as a worldview, he contended is based on materialism and monism. It

41 "Katholische Student und Politik," Academia 32, Nr. 5/6 (15. Sept. Oct. 1919): 152154. 
therefore contradicted the Christian worldview both in theory and in practice. ${ }^{42}$

The conflict between Catholicism and socialism, however, went much deeper than the simple (if critically important) question of religious belief. Revisiting the influence of St. Thomas, Catholic writers rejected the tendency of Marxist socialism (following its Hegelian legacy) to reduce the individual to what they called "subject oriented" behavior or "pure subjectivity." 43 As Franz Müller reminded his audience in 1928, human participation in the state was based on conscious awareness and free will. Each human being, according to Müller, represented both a person and a member of the political community. Through his spiritual being, the person was "originally" self-aware, selfresponsible, and aware (or at least capable of being aware) of his responsibility of being a member in the community. This awareness and free will, according to Müller, did not diminish individual responsibility, but in fact, enhanced it. ${ }^{44}$

In 1932, Müller would emphasize that people had a dualistic nature. In his conception, the individual was not just a physical body,

\footnotetext{
42 "Katholische Student und Politik," 152-154.

${ }^{43}$ His conclusion here might be erroneous. As Hegel's defenders might respond, subjectivity means ideally recognizing one's interests and those of the community as identical. Similarly, for Marxism, Communism allows one the virtue to "take according to his needs and contribute according to his abilities."

44 Referat, Müller, 150-152.
} 
but also a vehicle for the realization of imminent spiritual potential. People cannot be reduced to pure utilitarianism, he counseled, or pure animal corporality. People in their essential constitutional makeup were both biological and ideal. ${ }^{45}$ All true communities, continued Müller, depended on a tension between being a person and membership. ${ }^{46}$ A state order that sought to restrict the essence of a person is "violence, but not order." He concluded that such an order “.... achieves only a pseudo-community." 47

Müller warned that, under the influence of Prussian social welfare politics, Germans had lost their awareness of self-help. "We await help from above" he lamented, as the state all the more acquired new spheres of paternal oversight. Müller characterized the contemporary Weimar state as a species of state socialism, where politics and the economy had become fundamentally the same. In opposition to this arrangement, he insisted, "Catholic sociology must be brought back into memory." This sociology saw the individual not just as a member, but also a person, responsible to community and to self. "This is not about synthesis or compromise" he clarified, but the unity between two tensions. The interplay between the two poles made true community

\footnotetext{
45 Müller, "Vom Wesen des Politischen...," 1-7.

46 Personsein und Gliedsein

${ }^{47}$ Referat, Müller, 150-152.
} 
possible. ${ }^{48} \mathrm{~A}$ contributor to the KV journal strongly echoed Müller's ideas three years later, when he argued that the Catholic state doctrine represented a "golden mean" between individuals and collectivism, as a resolution between "two errors." 49

Following a similar line of argument, Josefine Kremser opposed the Catholic concept of the state to social democracy. Socialism, she surmised, demanded the nationalization ${ }^{50}$ of the means of production for the general welfare. Communism, an even more extreme form of collectivism, advocated nationalization in order to facilitate the redistribution of wealth. Therefore, both proposed to eliminate the right of the individual to private property. Kremser reminded her reader that both Aristotle and Thomas Aquinas had affirmed private property as a natural institution. The "nationalization of education," likewise an essential element in the platform of the SPD and the KPD, would strangle the natural right of parents. She concluded "We must decidedly reject the violation of law advocated by the proponents of (socalled) social welfare." 51

\footnotetext{
48 Referat, Müller, 150-152.

49 Demonstrating the powerful effect that scripture could have on a contemporary audience, Tischleder, to emphasize the point, added 2 Corinthians 13:8 ("For we cannot do anything against the truth, but only for the truth.") Tischleder, "Der katholische Staatsgedanke...," 120-126.

50 Verstaatlichung

51 Kremser, "Katholische Politik - Streflichter," 6-11.
} 
A thorough and comprehensive rejection of Marxism appeared in the December 1929 issue of Unitas, ironically, just as reverberations from the recent stock market crash in the United States seemed to vindicate Marx's prophesies. Its author was Professor Theodore Steinbüchel, an alumnus of both the Unitas and the CV fraternities. Steinbüchel earned his Ph.D. from Strasbourg in 1910 after finishing his dissertation on Thomas Aquinas. He was ordained as a priest in 1913. He continued with his studies. His habilitation in 1921 was entitled: "Socialism as a Moral Idea." Through the next twenty years, he taught at Frankfurt, Giessen, Munich and Tübingen. In 2000, the CV Handbook listed Steinbüchel among its "important" alumni. 52

Steinbüchel began his 1929 article with a thorough critique of capitalism, which might at a quick perusal be confused with an authoritative summary of textbook Marxism. Capitalism, conceded Steinbüchel, required the rationalization of an economy based not on human bonds, but on earnings. In his way of thinking, the human individual under capitalism became both the subject and goal of the economy, being alienated and atomized in the process. On the other side of this development, for the sake of economic rationality, corporate bodies consolidated first nationally, and then internationally,

52 C.V. Handbuch. Herausgegeben von der Gesellschaft für Studentengeschichte und studentisches Brauchtum e.V. (Regensburg 2000), 588. 
monopolizing goals and enterprises, and determining prices and profits. Capitalism, argued Steinbüchel, required a certain social structure, a capitalist society whereby the person is separated from the means of production, from the products of labor, and ultimately, from meaningful connections with other persons. The individual in such a society becomes a means, not a "value." Under capitalism, Steinbüchel asserted, "without question" total wealth had risen. ${ }^{53}$ But in its advanced stages of capitalism, wealth had become increasingly concentrated, and the division of society into classes had become every sharper. The outcome he described as nothing less than a "dictatorship of owners." 54

This far in the critique of capitalism, Steinbüchel recognized fully that Catholicism and socialism shared remarkably similar affinities. That socialism sought to overturn the system of capitalist property and production was for Steinbüchel entirely understandable. True, socialism imagined a community of people in which "all personal property is no longer valued," but pushing the theories of St. Thomas on property to the extreme, Steinbüchel asserted that property itself was a communally contingent relation. In the sense that no individual

\footnotetext{
53 Marx would have agreed.

54 Von E.A.H Univ. Prof. Dr. Theodor Steinbüchel, "Katholischer Akademiker und Sozialismus," Unitas 70, Nr. 3 (December 1929): 37-42.
} 
could be isolated from the community, "so there is no private property in the exclusive sense." The absolute right to property, contended Steinbüchel, was morally unthinkable. ${ }^{55}$

Steinbüchel's argument that certain historically contingent production arrangements shaped property laws and rights is probably as close to classical Marxism as one can come. It comes as no surprise that not all Catholics shared Steinbüchel's seemingly left-leaning views on the subject of property. Erhard Schlund, spiritual advisor of the CV, affirmed the more traditional view that held private property to be the "fruit of labor and commerce," and therefore, the natural right for everyone. Yes, the poor must be looked after, but in Schlund's opinion, reforming capitalist society could be accomplished without compromising one of God's natural institutions. ${ }^{56}$

Where did Steinbüchel, otherwise so close, finally diverge from Marxism? Why did he conclude, in spite of so many similarities, that the Catholic and Marxist conceptions of community were fundamentally incompatible? First, Steinbüchel conceded that Germany's current capitalist arrangement was unacceptable. But any change, following from the Catholic concept of community, had to proceed not from a

55 Steinbüchel, "Katholischer Akademiker und Sozialismus," 37-42.

56 Erhard Schlund, "Kann ein Mitglied des C.V. Sozialdemokrat sein?" Academia 41, Nr. 3 (15 July 1931): 70-74. 
"distant utopian future ideal" but from the "realm of present conditions and within the realm of concrete historical possibilities ${ }^{57}$ in accordance with the ethical norms of love." A Christian conception of property, continued Steinbüchel, had to be ethically and religiously grounded. It "must be based in reality," founded on the historical person within the current historical situation. For this reason, "an absolute Communism of compulsion," meaning an attempt to remake and reconstitute society violently and unnaturally, was "not to be justified."58

Class opposition and class conflict were "facts of today's life," conceded Steinbüchel. The proletariat had within its voice the "echo of a moral goal," not just to have more in the way of material goods, but also to achieve a living relationship that would reverse the process of alienation, and would restore the sense of self, person and connection to community. To Steinbüchel, this goal was perfectly understandable. "The ethos of justice" reflected in Marxism "gives one a new incentive, the goal of participating in a genuine community as a moral idea." Catholicism, he believed, must recognize this idea and value it. Germany's Marxists, he admitted, could not be blamed for trying to

\footnotetext{
${ }^{57}$ Ironically, Marx leveled a very similar criticism against his opponents in The Communist Manifesto. Lenin likewise made a strikingly similar argument in The State and Revolution, when he reminded his reader that any transition to a proletarian society would require that proletariat state institutions evolve from their bourgeois predecessors, resembling them strongly in form, but not in content.

58 Steinbüchel, "Katholischer Akademiker und Sozialismus," 37-42.
} 
bring together opposites, "reconciling the classes in the highest community form in love and service." But, he countered: "An unethical conducting of the struggle, inspired by class hatred and accompanied by destruction, Catholicism cannot recognize."59

This condition certainly would have eliminated the German Communists from consideration as an alternate directional star for German Catholics. But it seemingly did not apply to the SPD. As even Erhard Schlund, normally an implacably foe of the SPD would admit, Germany's mainstream socialists had in their 1925 Heidelberg platform pledged to support the republic and work towards gradual reform of the German economy within the legal boundaries of the German constitution. 60

But Steinbüchel had more to say on the matter. "Simply recognizing class interests divorced from the interest of the entire society" cannot work, he insisted. It was however possible, he countered, to build "an organized community based not on class, but on order, not in the historical but sociological sense." He believed that the members of his proposed corporate orders under a properly structured constitutional arrangement would have the ability to recognize their

${ }^{59}$ Steinbüchel, 37-42.

${ }^{60}$ Schlund, "Kann ein Mitglied des C.V. Sozialdemokrat sein?" 70-74. 
responsibilities vis-à-vis each other and for the whole. ${ }^{61}$ On this subject, Steinbüchel and Erhard Schlund were on the same page. As Schlund would explain:

Workers are obligated to work honestly, employers are obligated to compensate workers fairly, and allow them to fulfill their religious obligations and to tend to their family responsibilities. 62

Catholics had to understand, continued Steinbüchel, that any constitutional ordering of society must take into account all community members. "Therein the class conflict as the single principle of building the community for Catholicism is unacceptable."63

Marxist socialism, instructed Steinbüchel, was a child of the Enlightenment, a combination of young Hegelianism and Feuerbach's philosophy that sought to reduce the Christian religion to history and anthropology. Falsely, Steinbüchel believed, Marxism simplified the will of the individual to a kind of determinism conditioned by economic relations of classes in dialectical opposition to each other. To state the problem another way, the individual, as Marxist sociology would have it, was reduced to a mere "reflex" of production. Catholicism, he asserted,

\footnotetext{
61 Steinbüchel, "Katholischer Akademiker und Sozialismus," 37-42.

62 Schlund, "Kann ein Mitglied des C.V. Sozialdemokrat sein?" 70-74.

${ }^{63}$ Steinbüchel, "Katholischer Akademiker und Sozialismus," 37-42.
} 
can never recognize the individual as a simple product of material relations. ${ }^{64}$

Otherwise, Steinbüchel concluded, the Marxist analysis of capitalist economics is not in contradiction to Catholicism. Like Marxism, the Catholic ethical doctrine recognized that property was conditioned by the socially obligated demand to labor. For this reason, he recommended, Catholicism should take worker resentment against essentially parasitic capitalists seriously. But, the idea of class struggle embedded in socialism "contradicts the organic community constitution of Catholicism...."65

Steinbüchel reminded his reader that Soviet Bolshevism had deviated radically from Marxism in a number of critical respects. This is no trivial distinction without a meaningful difference. The specter of Bolshevism terrified Germany's Catholics. An article appearing in the May 10, 1930 Augsburger Postzeitung, for instance, reporting on a meeting of a local Catholic fraternity chapter, opened with the claim that "Bolshevism is marching not only in Russia and China, but also in Germany and Bavaria." 66 On January 15, 1932, an article authored by

\footnotetext{
${ }^{64}$ Steinbüchel, "Katholischer Akademiker und Sozialismus," 37-42.

65 Steinbüchel, "Katholischer Akademiker und Sozialismus," 37-42.

66 "Gegenwartsaufgaben des katholischen Korporationsstudentenen: Anläßlich des 31 Stiftungfestes der kath. Studentenverbindung Ludovicia-Augsburg von Pfarrer ValleisAitrag," Augsburger Postzeitung 4, \#107 (10 May 1930).
} 
Schlund catalogued the wholesale destruction of religious life in Russia that had resulted from the Bolshevik Revolution. Part of Schlund's point was to remind his reader of what the ersatz religion of Bolshevism would have in store if it should triumph in Germany. ${ }^{67}$ More apocalyptically, Hans Bremser of the Catholic Ring fraternity warned in 1928 that Soviet Communism threatened to usher in a "new Middle Ages." 68 Communism, averred Bremser, could be considered the fulfillment of Nietzsche's prophesy that Europe would degenerate into the lowest barbarism, threatening not just "its culture but its existence." Looming on a horizon covered by black clouds, Communism in Russia waited for the occasion to set its ideas loose on a weak, powerless and divided Europe. ${ }^{69}$

This is not the sinister vision that Marx had in mind, contended Steinbüchel. Emphasizing the role of both Kant and Hegel in Marx's early intellectual development, Steinbüchel argued that Marx, knowingly or unknowingly, had contemplated a kind of communitarian categorical imperative that saw the individual as a product of self-value, not just commodity price. The tragedy of Marxism, continued

\footnotetext{
67 Erhard Schlund, "Der Sieg des Bolshewismus über die Kirche in Rußland," Academia, 44, \#9 (January 15, 1932): 236-239.

68 Perhaps an ironic slip, in that many of his Catholic contemporaries had a positive view of the Christian Middle Ages. See Chapter 6.

69 Bremser Hans, stud. Jur. (Rheno-Pfaria, München), "Krise der Gegenwart”, Der Ring 4, 89 (November 1928): 80.
} 
Steinbüchel, was that its "bourgeois" materialism, its fundamental tendency to reduce human beings to economic and productive relations, very much informed its atheism. Marx's conception of the human individual and his rejection of religion could not be analytically separated. Steinbüchel saw it as no accident that that the Social Democratic Party in Germany had agitated against the Catholic Church and its institutions for decades. Unfortunately, even with the best of intentions, Catholics could not expect the SPD to moderate its tone, no matter what its leaders might say or write publicly. ${ }^{70}$

In any event, wrote Steinbüchel, Germany's workers had better options. What socialism advertised was more truly and faithfully represented in Catholicism. Catholicism demanded a community of participation in an economy of human personalities that recognized justice as the basis of work, property and social relations. Catholicism offered a better vision because it sought to overcome class conflict not with its resolution in favor of any one class, but by its overcoming with a new concept of community and society. Stated another way, Catholicism represented a meaningful and better alternative to socialism by offering social justice as an antidote to the atomized society of the present. He argued:

\footnotetext{
70 Steinbüchel, "Katholischer Akademiker und Sozialismus," 37-42.
} 
Catholicism is an eschatological position, which in the present obligates one to struggle for values which are eternal and demanded by God - it privileges the eternal over the contemporary - it is grounded on the humanistic idea of respect and honor for the individual... and the unity of community based on the principle of love.

In the shorter term, Steinbüchel called on Catholic students to reach out "as brothers" to the German proletariat. ${ }^{71}$

\section{Church and State}

Of course, the SPD offered a more obvious target of Germany's Catholic fraternity writers because of its self-professed atheism and its platform that sought to relegate the Church to the status of a private, subordinate institution. When rejecting Germany's mainstream socialists, however, Catholics offered radically differing conceptions of the state, its origins, and its field of authority vis-à-vis other institutions in German society. Catholic writers affirmed the notion offered by St. Thomas (as explained in Chapter 3) that the state should be considered as part of God's given, natural order. But, it did not thereby follow in their reasoning that the state was theoretically omnipotent, as socialist political ideology (at least in the minds of Catholic writers) allegedly claimed. For one thing, Catholics countered, the state should never be seen as a supreme authority. They state, they insisted, must operate in

\footnotetext{
71 Steinbüchel, "Katholischer Akademiker und Sozialismus," 37-42.
} 
harmony with other natural institutions, such as the family, and the Church, all with distinct juridical responsibilities and rights.

The subordinate role assigned to the Church by the Weimar constitution provided perhaps the most salient point of criticism for Catholic writers. Through the 1920 s, Catholic commentators in the fraternity newspapers continued to believe that the state and the church should be considered as "perfect societies,"72 each legally equal and distinct with overlapping matrices of jurisdiction relating to the family, education, and morality, among other things. Although he recognized that the Church could not be expected to order "every little detail" of life, Dr. Ernst insisted that the secular authorities do nothing to injure its moral prescriptions. ${ }^{73}$ In so doing, Ernst was consistent with prevailing Catholic theology in suggesting that the Church should be seen as legally equally, but morally superior to the state. He concluded:

The state has certain limitations.... It cannot order anything against God or against his morality. Because the state has the obligation to ensure the human welfare, and since the soul in the imminent sense is part of this welfare, then the first task must be for the state to support and promote it. ${ }^{74}$

\footnotetext{
72 For a fuller elaboration, see Chapter 7, particularly as supported by the helpful analysis of Robert Krieg.

${ }^{73}$ Here, he leaned on Leo XIII: "the different state forms are acceptable to the Church, as long as religion and moral commandments are not injured."

${ }^{74}$ Ernst, "Katholizismus und Politik...," 136-142.
} 
For this reason, Catholic commentators in the fraternity journals looked on approvingly when the Catholic Center Party fought its own coalition partner tooth and nail on plans to deactivate confessional education in German society. ${ }^{75}$ They likewise supported the Center when it sought to revive the Church's supervisory role in marriage and other family matters.

Although she saw the state as a natural institution, Josefine Kremser rejected the notion that state power was theoretically limitless, or not circumscribed by any institution other than the power of its own law. 76 The state power, she insisted, quoting Pius IX and the Syllabus of Errors, had its limits. ${ }^{77}$ Following papal authority, she argued that the power of the state was limited from below by the rights of the individual and family and from above by the "Godly" right of the

75 The Weimar constitution had never settled the issue. The German school system, as had been the case during the Kaiserreich, saw both exclusively confessional schools (i.e., only Catholic or only Protestant), and interdenominational schools (both Protestant and Catholic - and in some cases Jews, who attended religious instruction classes separately, but attended other classes together). Catholics and conservative Protestants argued that parents should always have the right to send their children to the former. Moderates in the DDP and DVP usually opted for the latter. Some socialists called for the elimination of religious instruction in Germany's public schools altogether.

76 Interestingly, both Aristotle and Thomas Aquinas recognized that, for a leader to be restrained by his own subjects is a contradiction in terms. The best that one could hope is that the leader is sufficiently responsible to restrain himself.

77 Specifically, Leo rejected the idea that: "the State, as being the origin and source of all rights, is endowed with a certain right not circumscribed by any limits." "Der Staat erfreut sich eines Rechtes, das durch keine Grenzen umschrieben ist." 
Church. ${ }^{78}$ The state depended on the Church for people to obey the laws, and for the maintenance of civic virtue. Conversely, the Church needed the state to collect taxes on its behalf and to protect it physically from external enemies. Leaning on no fewer than three different papal precedents, ${ }^{79} \mathrm{Kremser}$ would reiterate her belief that the idea that the state must be separate from the church "is a totally false, corrupt doctrine."80

Kremser asked: how does one reconcile state and church? She responded with a formulation standard to Catholic political thinking in her time. The state and church were perfect societies, she contended, each with its own purpose and the means to reach it, each independent and within its realm supreme. Not so incidentally, she believed this to be one of the fundamental points of divergence between Protestants and Catholics in Germany. The Protestants, she opined, continued to recognize the Church as a spiritual authority in matters of faith, but denied that it had its own Church law, outside of the laws of the state. Germany's Protestants thereby held to the fallacy (also rejected in the

78 Kremser, "Katholische Politik - Streflichter," 6-11.

79 Gregor XVI (1832), Pius IX (Syllabus of Errors), and finally, Pius X (1906) and his encyclical Vehementer

80 Kremser, "Katholische Politik - Streflichter," 6-11. 
Syllabus of Errors) that the church stood in a subsidiary position vis-àvis the state, as a fully private association. ${ }^{81}$

Both powers, church and state, Kremser held, should be sovereign and supreme and circumscribed by certain boundaries. One concerned itself with the task of contemporary welfare, the other, with the eternal welfare. "Contemporary and eternal, natural and supernatural" are not easily separated, Kremser argued. They overlap to the degree that both church and state entities have power over the same people. So it can happen, she continued, citing funerals, holidays, education, marriage and social welfare, that one and the same matter falls into the jurisdiction of both secular and spiritual. Above all else, Kremser pointed to the persistent and seemingly irreconcilable issue of Weimar confessional politics, namely, schooling. ${ }^{82}$

On this ground, Kremser, like much of her Catholic cohort, rejected the notion, then axiomatic for Germany's Social Democrats, that the state should have the exclusive right to determine the content of primary and secondary education. That the Church had a right to oversee education, Kremser believed, "we must again and again establish" on three bases:

${ }^{81}$ Kremser, "Katholische Politik - Streflichter," 6-11.

82 Kremser, "Katholische Politik - Streflichter," 6-11. 
1. The Church had the right and duty to provide religious instruction and to entrust this to certain people.

2. The pastoral office of the Church had the right and duty to ensure that the other subjects taught as part of the curriculum did not compromise religion.

3. Education is at the same time upbringing, ${ }^{83}$ she concluded. This means that the ethical and religious requirements of education should be determined by the Church.

The church and state are simultaneously sovereign powers, she reminded her reader. Questions between the two must be resolved on an equal basis. The relationship cannot be ordered exclusively by the state. Nonetheless, she conceded that "the concept of the independent church has fallen on dark times for the Catholic population." She had in mind those like the "Protestant politician," H.V. Schubert, who had in recent times supposedly gloated: "...for Catholics, and the German Catholics, there is only one law, the law of the state." The state and church, she concluded, were surely distinct authorities, but "we should remember" that they are not totally separate. Between the two there was a "living, organic" connection. In response, she argued that it was the duty of Catholic writers to awaken the Catholic people so that they

${ }^{83}$ Unterricht ist gleichzeitig Erziehung 
recognized the Church's rights vis-à-vis Germany's all-too invasive secular authorities. ${ }^{84}$

\section{Conclusion}

As Dr. Ernst reminded his reader, the good Catholic need not be indifferent to the state form. "But never," he demanded, should Catholics consider revolution as an acceptable means of altering or replacing the constitution. ${ }^{85}$ Nonetheless, Catholic fraternity writers found in the Weimar constitution much to criticize. Even if they would not reject the idea of democracy per se, Catholic fraternity writers denounced the "competitive" nature of Germany's democracy. Fraternity writers believed that competitive party politics reflected German capitalism, which they opposed as essentially contradictory to the principle of cooperation embodied in the Church's teachings. For this reason, Franz Müller rejected the "friend/foe" paradigm of politics then being offered by Catholic political theorist Carl Schmitt. ${ }^{86}$

Leaning on their own historical reading of the Middle Ages, Catholic fraternity writers argued that the various orders of German society, including workers, must be represented cooperatively and

\footnotetext{
${ }^{84}$ Kremser, "Katholische Politik - Streflichter," 6-11.

85 Ernst, "Katholizismus und Politik...," 136-142.

${ }^{86}$ Müller, "Vom Wesen des Politischen...," 1.
} 
corporately in Germany's parliament. On the other hand, these writers rejected parties like the SPD insofar as they represented class or particular interests.

Stephen Frederick Schneck's analysis of Max Scheler (18741928), who sojourned with Catholicism briefly during the last two years of World War I and then through the early Weimar period, helps to clarify more precisely the basis whereby Catholics rejected both capitalism and socialism on the same philosophical grounds. Informed by the "lived experience" ethos associated with Nietzsche, Bergson, and Dilthey, which had strongly appealed to Germany's youth in his time, Scheler would argue that any workable notion of community had to recognize two essential facts. First, Scheler characterized the human personality as an "achievement of his or her sociality." Personality abstracted from community and culture is nonsense. But at the same time, the person's ability to get along in the community is impossible without the agency of his or her individuality. Scheler agreed with other Catholics that classical liberalism rested at the foundations of the Weimar constitution. He believed that this doctrine had erred in seeing the discreet individual as the building block for the community. Scheler likewise criticized liberal individualism for failing to do "full 
justice for the individual." He would clarify (as paraphrased by Schneck):

True individuality requires the mutual acceptance of the unique personhood of one's own person, other persons and the person of the community as a whole. Because the liberal scheme sees the community as dependent upon the parallel but separate actions of distinct individuals, the dignity of the unique personhood of the others and the community is precluded. Denying the subjectivity of the community and others undermines the possibility of the individual's own subjectivity. ${ }^{87}$

The historian of Weimar might quibble with the tendency shared by Scheler and the Catholic fraternity writers to classify Weimar onedimensionally as a liberal state. Based on its statutory commitment to the social welfare, the Weimar constitution was seen in its time, and later, as embodying a number of strikingly socialist features.

But, Scheler would respond that his critique of "bourgeois individualism" could likewise be applied to Marxist socialism. Like many of his Catholic cohort, Scheler sympathized with Marx's call for social justice and his condemnation of a capitalist economy that shattered the bonds of community and reduced human relations to property and commodity. As Schneck explains, Scheler borrowed Marxist categories of analysis freely for his own purposes. So did contemporary Catholic fraternity writers. Scheler rejected Marxism,

\footnotetext{
87 Stephen Frederick Schneck, Person and Polis: Max Scheler's Personalism as Political
} Theory (Albany: State University of New York Press, 1987), 102-103. 
however, "in a general sense" because he found "it mired in the curious value complex of bourgeois man." To put it succinctly and precisely, Scheler believed that Marx erred (in Schneck's words) in accepting "unwittingly and without reflection... bourgeois man's myopic focus on the values of utility as the "measure of all things." 88

Scheler likewise rejected Marx's vision of history, particularly the idea that the historical dialectic would resolve class conflict. To Scheler, the dialectical interplay between opposites, a "process of friction grinding away in linear march towards a chiliastic progress," threatened to eradicate the uniqueness of the human personality rather than redeem it from the alienation of capitalism. True, the "gravel grinding machine of bourgeois competition" had already pounded the "creative differences among persons into the common mass of society," as Schneck so aptly and elegantly describes it. But since Marxism and capitalism shared the same essential understanding of the individual as a producing and consuming mechanism (and nothing more), Scheler feared that the dialectical resolution of conflict prophesized by Marx would "unwittingly" complete the process. ${ }^{89}$

It goes without saying that Christian historical eschatology would reject Marx's final vision of communism as the realization of an

\footnotetext{
88 Schneck, 113-115.

89 Schneck, 121.
} 
atheistic kingdom of heaven on earth, in which humanity is redeemed through the redistribution of material things. Scheler's decision to part ways with formal Catholicism in the early 1920s should not obscure the essential congruities between his rejection of bourgeois and Marxist individualism and contemporary critiques authored by other Catholic writers.

The preceding discussion should make clear that Catholic writers rejected the subordination of the Church to the state under Weimar's constitution. Knowing full well that Catholics were a minority in Germany, these writers offered little in the way of criticism against the provisions of the Weimar constitution that guaranteed freedom of worship. But, they insisted that church and state be recognized as legally distinct and equal entities with overlapping jurisdictions. They likewise affirmed the Center Party when it resisted the government's efforts to curtail the confessional content of German primary and secondary education. They also called for the restoration of the Church's juridical right to supervise marriage, child rearing and other endeavors deemed essential to the inculcation of moral and ethical values.

Whatever their attitudes towards Weimar, instructed Dr. Ernst, Catholics must love their fatherland. Patriotism, in his mind, meant 
obeying the law, even if "one is not in agreement with the state form or the state authorities."90 But, especially after global depression pushed many Germans against their current constitution implacably and irretrievably, many Germany Catholics came to realize that ambivalence towards the constitutional state form represented a dangerous mindset. As a contributor to an Augsburg newspaper, reporting on a meeting of a local Catholic fraternity chapter in 1930, warned: "Politics is the conception of the state, and in today's democratic state, the situation is so: either we work to shape the state, or the state will shape us." 1

90 Ernst, "Katholizismus und Politik...," 138.

91 "Gegenwartsaufgaben des katholischen Korporationsstudenten: Anläßlich des 31 Stiftungsfestes der kath. Studentenverbindung Ludovicia-Augsburg von Pfarrer Valleis- Aitrag" Augsburger Postzeitung 4, \#107 (10 May 1930). 


\section{Chapter 6}

\section{A Catholic Commentary on German Nationalism}

For some time, we have been caught in an exhausting struggle of ideology and party. We hear the seemingly reasonable demand to love and honor Germany, both in word and in deed. And often, we hear from a small group of people who insist on the right to brand as a traitor to the nation anyone whose ideas differ from theirs. And from another direction, the demand for international solidarity, brotherhood, and world peace rings ever louder in our ears. Every thinking-German is hurled into this confusion of ideas - especially the German Catholic, who is all too easily accused of inadequately loving his country. In these difficult times the Catholic will have to ponder, clarify, and resolve the question: what is the relationship between his Catholicism and love for the fatherland? Adalbert Oberthür, Theologian, Member of the Catholic Unitas-Frisia Union, University of Münster, $1926 .^{1}$

For much of the late twentieth century, the most important contributors to the literature on nationalism have downplayed or minimized the impact of religion on the formation and maintenance of national identity. Highly venerated proponents of the "modernist" reading of nationalism, Ernest Gellner and Benedict Anderson, among others, relegate universal religious communities to the list of history's relics. This catalogue of antiquities also includes, among other things, untranslatable sacred script languages, self-enclosed clerisies and inwardly isolated peasant communities. Gellner and Anderson tell us

\footnotetext{
${ }^{1}$ Adalbert Oberthür, "Katholizismus und Vaterlandsliebe," Unitas 66 (June 1926): 173.
} 
that religious loyalties fade, fragment or become territorialized, when modern forces like encroaching state bureaucracies, capitalism, print technologies, urban culture and vernacular reading markets draw collective loyalties inexorably to the nation-state.

In Gellner's description of pre-industrial society, religious authorities played a leading role in imposing cultural norms on illiterate and locally reproduced peasant communities. Impressed by their selfconstructed mystique, the religious strata in these settings stood physically and symbolically aloof from their subaltern surroundings. Their separation from society served as both source and symptom of their self-proclaimed right to define and enforce culture. Before the arrival of the nation-state, Gellner tells us that clerisies commanded considerable political authority in their own right, including, in some cases, sovereignty over independent territorial jurisdictions.

In the industrialized world, all of this changed. In Gellner's words, the modern state created vast reservoirs of ready-made mass industrial labor by turning "everyone into a cleric." At the dawn of the Age of Nationalism, high culture appropriated and replaced clerical culture, including its rituals and values. In the process, the national state, by virtue of its monopoly on the means of coercion and, even 
more importantly, the means of education, rendered religious authorities politically irrelevant and culturally redundant. ${ }^{2}$

Benedict Anderson, another venerable contributor to the literature, locates the emergence of modern nationalism at precisely the moment when vernacular print capitalism pushed Latin Christendom out of the publishing business. According to Anderson, Europe's universal Christian hierarchy relied for centuries on its privileged ownership of a sacred, untranslatable script as the source of its importance. When literate vernacular publics, the embryos of later national cultures, began to read in their own languages, the religious hierarchy lost its right to mediate "between earth and heaven." The modern national state, in Anderson's narrative, capitalized on the downfall of the universal religious community by filling the psychic void it had left behind. The triumph of the nation, in Anderson's words, left the sacred community of Latin Christendom permanently "fragmented, pluralized, and territorialized."3

The modernist reading of nationalism represents the choice between national and religious loyalty as a permanently binding either/or. While the individual may harbor sentiments for both a

\footnotetext{
2 Ernest Gellner, Nations and Nationalism (Ithaca: Cornell University Press, 1983), 16-
18, 32 .

3 Benedict Anderson, Imagined Communities: Reflections on the Origin and Spread of Nationalism (London and New York: Verso, 1991), 12-19.
} 
religious and a national authority, the modernist paradigm assumes that the primal sense of loyalty must attach itself to one or the other. In the struggle between church and nation, the nation must win. In the modernist paradigm, its victory is permanent.

Steven Grosby, representing a challenge to the standard modernist paradigm, reminds us that nationalism and religion share important attributes. Broadly, they both order human cognition and demand individual submission to a greater whole. But, as Grosby also argues, the two operate on very different planes of meaning. Nationalism demands individual submission to the here and now. Systems of religious faith, by contrast, exhort their followers to recognize metaphysical truths valid beyond the limits of their own lifetimes and beyond the borders of their geographically bounded communities. It is for that reason, as Grosby tells us, that the historical persistence of religious communities has caused ...innumerable difficulties for the solidarity of the national state - the stability of its self-understanding - for the events of this world unfailingly prove to be resistant to being brought into order with the perceived purpose to history, that is, the purpose of God. ${ }^{4}$

\footnotetext{
${ }^{4}$ Steven Grosby, "Nationality and Religion," in Understanding Nationalism, Montserrat Guibernau and John Hutchinson, editors (Oxford: The Polity Press, 2001), 97-113.
} 
As Grosby concludes, religion will continue to play an integral role in both promoting and threatening the construction and maintenance of national identity.

Through the centuries, nationalists in Europe have set a high premium on religious unity when seeking to secure national integrity. Adrian Hastings has suggested that early proponents of the national idea, emerging first in late medieval England, had etched indelibly in their minds the lessons of the Christian Old Testament. These early nation builders paid particularly close heed to the Biblical admonishments to the ancient Israelites, as they emerged from forty years of isolation in the desert. In the book of Joshua, the community of Moses and Aaron was prohibited from allying, intermarrying, or intermingling with other peoples. Centuries later, conquered and dispersed by Assyrian and Babylonian invaders, the descendents of Abraham had nobody but themselves to blame, for they had lapsed into practicing "all of the abominations of the nations." As the book of Kings had explained:

This came because the Israelites sinned against the Lord, their God, who had brought them up from the land of Egypt, from under the domination of Pharaoh, king of Egypt, and because they venerated other gods. They followed the rites of the nations whom the Lord had cleared out of the way of the Israelites.

\footnotetext{
52 Chronicles 36:14 (The New American Bible, 1969).
} 
The warning continues: "The vanity they pursued, they themselves became: they followed the surrounding nations whom the Lord had commanded them not to imitate." The books of Kings and Chronicles explained to later Christian readers that the national communities of Israel and Judah had sinned collectively by assimilating the religious practices of foreign peoples. For breaking a covenant that forbade religious eclecticism within their ranks, the ancient Israelites incurred the veritable death sentence of nations: the loss of sovereignty, the physical dismemberment of their community and their geographic dispersal as a people. As Hastings tells us, the lesson of Israel impressed upon Christian Europe's later nation builders the importance of religious unity in incorporating and maintaining the national community. ${ }^{7}$

As Anthony Marx reminds us, early nation builders in Europe demanded not only the promotion of religious conformity, but also, the elimination of religious nonconformity. From the fifteenth century onwards, state actors in Spain, France and England found it necessary to mobilize and consolidate loyalty to their expanding realms of authority by evicting Jews, Moors, Huguenots and other religious

\footnotetext{
62 Kings 17:7-15 (The New American Bible, 1969).

7 Adrian Hastings, The Construction of Nationhood: Ethnicity, Religion and Nationalism (Cambridge: Camrbidge University Press, 1997).
} 
nonconformists. ${ }^{8}$ Similar nation building endeavors elsewhere have not always been as effective. When states fail to produce a unified community of belief within their borders or, when they fail to sever the local religious annex from its multinational moorings, both the definition of national identity and the parameters of the national community can become discursively and, in the extreme case, physically contested battle zones.

\section{The German Context}

Few historians today would suggest that Germany's Catholics posed a potentially fatal danger to German national integrity in the decades after 1871, even if Germany's contemporary leadership believed otherwise. After 1871 and, especially after 1918, the majority of Germany's Catholics accepted three essential premises. First, Catholics agreed that a German national community existed and had existed in historical memory. Second, most Catholics believed that they were part of this national community. Third, most Catholics agreed that the German nation should coincide with some form of state entity. As most contributors to the literature from the past twenty-five years tell us, believing in a nation, affirming membership in that nation and calling for its consolidation within the boundaries of a unified state represent

\footnotetext{
8 Anthony Marx, Faith in Nation: Exclusionary Origins of Nationalism (Oxford: Oxford University Press, 2003).
} 
the fundamental requirements for affirming and articulating national identity.

After German unification in 1871, however, Catholics continued to affirm and articulate their German national identity on their own terms. Well into the twentieth century, Germany's Catholics harbored deep reservations towards a national state that was essentially Protestant and increasingly secular. Very often, Catholics sided with the Vatican in its conflicts with Berlin over issues of fundamental importance to Catholic faith and practice. Catholics continued to express strong sentimental attachments to historically sovereign provincial entities that had only recently been incorporated into the German Reich. ${ }^{9}$ Catholic Germans also expressed their sentimental allegiance to entities that had not been incorporated into the Reich, most notably, Austria. Germany's Catholics took decades to warm to the official patriotism promoted by the imperial government. Long after German national unification, Catholic political interests continued to obstruct the implementation of many priorities considered to be of critical national importance by Germany's ruling elites.

After 1918, Germany's Catholics continued to form a distinct, if increasingly diversified confessional community, with their own

\footnotetext{
9 This was true particularly for the Rhineland and Bavaria.
} 
religious institutions, social infrastructure, press organs and political parties. The Catholic faith and religious practice still informed powerfully the priorities of nearly all Catholic political and social institutions. Through their public institutional structures, Catholics after 1918 searched, sometimes awkwardly, for the right vocabularies and paradigms to articulate and affirm their patriotism in a way that did not override or contradict Catholicism. For Germany's Catholics, affirming their German national loyalty had proved difficult, even after

1918. Catholics continued to live in an influential Catholic institutional community. They also mingled with a broader German public that included political parties, press organs, prominent intellectual circles and increasingly influential nationalist movements that expressed openly their profound hostility to Catholicism.

\section{The Fraternities and German Nationalism after World War I}

The question of German nationalism dominated German fraternity discourse after the Great War. At the war's conclusion, thousands of returning veterans hoped to revive the camaraderie of the trench by enrolling in the fraternities. By the mid-1920s, approximately two-thirds of Germany's student population claimed membership in a 
fraternity. ${ }^{10}$ Students from many of these fraternities, including the largest, the German Fraternity (DB), openly attacked the new republic, by charging that its parliamentary institutions contradicted Germany's historical traditions. They likewise expressed skepticism that Germany's government could ensure internal order or secure Germany's national interests. Through the 1920 s, as these very same fraternity students destabilized Germany's campuses, as they participated in broader actions against the republic's institutions, ${ }^{11}$ and as they articulated foreign policy demands that went far beyond the fatherland's realistic capabilities, their prophesies became self-fulfilling.

The German student umbrella organization, the DSt, likewise embodied the still vibrant nationalist energies of the war years. After the war, DSt leaders expressed their desire to reach out to all German students in Central Europe. Their expansive horizons included Austria, Czechoslovakia, Poland, Romania and elsewhere. What defined students as German, within the German Reich or beyond, however, proved to be controversial. The competing proposals for membership in

10 Gerhard Schäfer, "Studentische Korporationen im Ubbergang zum deutschen Faschismus," 1999 Zeitschrift für Sozialgeschichte des 20. und 21. Jahrhunderts 3 (1988): 111. Michael Stephen Steinberg, Sabers and Brown Shirts: The German Students' Path to National Socialism (Chicago: University of Chicago Press, 1973), 16, 21. Jürgen Schwarz, Studenten in der Weimarer Republik: Die deutsche Studentenschaft in der Zeit von 1918 bis 1923 und ihre Stellung zur Politik (Berlin: Duncker \& Humblot, 1971), 17.

${ }^{11}$ As explained in Chapters 3, fraternity students supported the Kapp Putsch in 1920 and Hitler's Putsch in 1923. 
the DSt in its early years read like a veritable menu of visions for a German national community. This menu included visions that defined Germans as all those holding formal German citizenship (civic nationalism), those who spoke German as their native language (cultural nationalism), those born of German origins (ethnic nationalism) and those considered "racially pure" Aryan Germans (racial nationalism). ${ }^{12}$

In its first meeting in 1919, the racial nationalist elements within the DSt insisted that non-Aryan ${ }^{13}$ be excluded from all organizations belonging to the body. A second meeting in Göttingen in July 21, 1920 witnessed another unsuccessful attempt to write a national constitution and resolve the question. In an attempt to conform to Prussian law, the DSt proposed to allow local student governments the option of granting membership to all German citizens, those of German descent and those of German mother tongue. But, the DSt also recognized the right of Austrian and Sudeten German student organizations to exclude Germans of allegedly non-Aryan ancestry. The decision of the DSt to admit these Austrian and Sudeten organizations to its ranks ignored the wishes of the Prussian educational authorities. Nonetheless, the

\footnotetext{
12 Hans Jürgen Rösgen, Die Auflösung der katholischen Studenten Verbände im Dritten Reich, Dortmunder Historische Studien, Bd. 15 (Universitätsverlag Dr. N. Brockmeyer,
1995), 30.

13 meaning, obliquely, Jews
} 
DSt settled on this compromise when it finalized its constitution at Würzburg in January 1924. Konrad Jarausch has characterized the Würzburg constitution as an early victory for the ethnic and racial visions of German national identity within the DSt. ${ }^{14}$ The DSt's 1924 Würzburg constitution set the criteria for membership in most of Germany's national student organizations until Hitler's takeover in 1933. Through that interval, prominent students and campus figures continued to disagree on what defined German national identity.

\section{The Dilemma for Catholic Fraternities}

Like their nationalist cohort in the DB, the DSt and elsewhere, many Catholic students sought to channel their war experiences into a fundamental political reorientation. ${ }^{15}$ For Germany's Catholics, the question of nationalism presented a difficult dilemma. For one thing, both the Catholic Center Party and the Catholic Bavarian People's Party (BVP) usually served as integral constituents of the "Weimar Coalition," which the nationalist elements on Germany's campuses roundly opposed. The Weimar constitution, whatever its faults, guaranteed the civic equality that had been denied to Germany's Catholics under the Kaiserreich.

\footnotetext{
${ }^{14}$ Konrad H. Jarausch, Deutsche Studenten: 1800-1970 (Frankfurt am Main: Suhrkamp Taschen Verlag, 1989), 146.

15 Schwarz, 209.
} 
While the war experience had encouraged Catholics to identify more intimately with the German nation, many Catholic fraternity students continued to believe that German patriotism should play a subordinate role, while their loyalties remained primarily with their Church and its organizations. ${ }^{16}$ As explained in 1921 by a contributor to the Unitas journal, the nation for the Catholic was a step, but not the final destination. For "him his international religion is the highest value." 17 While the CV had already articulated an official platform in support of the German fatherland before World War I, the KV and Unitas continued to waiver. The KV finally had to settle in 1919 with the ambivalent official slogan, "With God for German Honor."18 Unitas included no patriotic slogans on the front cover of its journal.

The Catholic fraternities confronted the same "Aryan paragraph" membership controversy faced by the DSt. Of course, observant Jews would be barred from the Catholic fraternities in any event. But the fraternities did have to consider the case of Jewish converts to Catholicism or Catholics descended from Jewish parents or grandparents. ${ }^{19}$ Some CV leaders worried that Germany's nationalists

\footnotetext{
${ }^{16}$ Rösgen, 22.

17 "Hochschulring deutscher Art," Unitas 61, \#3 (April 1921): 61-62.

18 Mit Gott für deutsche Ehre. Friedhelm Golücke (Ed.) Korporationen und Nationalsozialismus (Schernfeld: SH-Verlag, 1990), 14.

19 This question is addressed in greater detail in Chapter 7.
} 
would very easily channel racial and anti-Semitic sentiment into attacks against "ultramontane" Roman Catholicism. ${ }^{20}$ In its 1919 convention held in Würzburg in that year, the CV rejected the Aryan Paragraph. ${ }^{21}$

The Aryan controversy revived a year later at the CV assembly held at Regensburg, however. At this meeting, the CV faced stronger demands, particularly from its Vienna chapter "Franco-Bavaria," that the fraternity laws be amended to bar "pledges of Semitic descent, traceable to the grandparents." According to CV historian Peter Stitz, "three well known Cartel members from Vienna reported that the racial question was one of life and death for the Vienna CV." Stitz speculates that anti-Semitism exerted a strong influence in Vienna due to the legacy of former mayor Karl Lueger, 22 as well as the recent influx of Jewish refugees from Eastern Europe (Ostjuden) that had contributed to a powerful backlash among some of the city's inhabitants. Stitz's argument has clear merit. In 1927, a CV graduate student wrote an article in Academia that recognized Lueger as one of the founders of the Austrian anti-Semitic movement, but nonetheless lauded the former

\footnotetext{
20 To clarify, nationalists continued to charge that Catholics were loyal to a foreign authority (the Pope) "beyond the mountains" (the Alps) - the literal meaning of "ultramontane."

21 Rösgen, 47-49.

${ }^{22}$ According to a number of accounts (including Hitler's own), a formative influence on the anti-Semitism of former Vienna resident Adolf Hitler.
} 
mayor of Vienna as a convinced Catholic, a defender of German values, and a supporter of the Catholic fraternity movement in Vienna. ${ }^{23}$

Those in attendance at Regensburg provisionally approved the measures against just two dissenting votes. But on an issue affecting the statutes of the national fraternity, CV governing regulations demanded a vote from all individual fraternity chapters. The majority of these chapters from the German Reich voted against the measure. The so-called "Aryan paragraph" was never again presented to a CV deliberation. ${ }^{24}$ The KV and Unitas fraternities likewise officially rejected the application of the Aryan paragraph in their own membership regulations.

As explained in Chapter 3, nationalist organizations like the German University Ring or DHR appealed to some Catholic fraternity members. The DHR and its affiliated organizations encouraged Catholic fraternity members to distance themselves from the Catholic Center Party, in part, because of its collaboration with the SPD and its support

\footnotetext{
23 Von cand. Phil., Anton J. Walter, N.C., "Der Lueger als Noriker: Eine Bürgermeisterrede vor 25 Jahren,” Academia 39, Nr. 10 (February 15, 1927): 198-200. ${ }^{24}$ Rösgen, 47. Peter Stitz, Der CV 1919-1938. Der hochschulpolitische Weg des Cartellverbandes der Katholischen deutschen Studentenverbindungen (CV) vom Ende des. 1 Weltkrieges bis zur Vernichtung durch den Nationalsozialismus (Munich: Herausgegeben von der Gesellschaft für Studentengeschichte und studentisches Brauchtum e.V., 1970), 44-45.
} 
for the republic. ${ }^{25}$ Encouraged by Martin Spahn, some Catholic students believed that participating in the DHR would serve Germany's national cause by bridging the historical divide with their Protestant cohort. Some also feared that, with nationalism growing dramatically on Germany's campuses, Catholics might once again miss the boat on a seemingly modern and progressive idea.

On Germany's campuses, Catholics deflected with awkward difficulty the charge leveled by some DHR supporters that Catholicism represented an internationalist ethos inimical to German national interests. Even if the DHR claimed to be above party and confession, Catholics could see easily that the DHR's official slogan ${ }^{26}$ represented an obvious attack against the universalism of the Catholic Church. As a contributor to Unitas reminded his reader in 1921, "Is that not the sound, which from certain corners before the war rang constantly in our ears?"27 Catholic fraternity contributors worried more broadly

\footnotetext{
25 Hans Peter Bleuel and Ernst Klinnert, Deutsche Studenten auf dem Weg ins Dritte Reich. Ideologien-Programme-Aktionen 1918-1935 (Guterslöh: Sigbert Mohn, 1967), 185.

26 "Wir kämpfen gegen den Internationalismus jeder Färbung," or "We struggle against internationalism of every color." In German nationalist nomenclature, socialism was referred to as a "red" international and Catholicism as a "black" international. As was the case with the DHR's slogan, nationalists frequently grouped the two together. 27 "Sind das nicht Töne, we sie uns vor dem Kriege aus gewissen Ecken immerfort um die Ohren wehten?" "Hochschulring deutscher Art," Unitas 61, \#3 (April 1921): 61.
} 
about the DHR's "national chauvinism" and "anti-Semitic racial fanaticism."28

After the Catholic fraternities bolted from the DHR in the aftermath of Hitler's Putsch in 1923, some Catholics continued to search for organizational outlets for their patriotism. In 1926, a handful of Catholic academics established the Görres Ring. The founders of the Görres Ring believed that the organization would allow Catholics the opportunity to affirm their dedication to the German nation without compromising their loyalty to Catholicism and its institutions. In an evident attempt to preserve the spirit of the DHR slogan, but to eliminate the implied reference to Catholicism, supporters of the Görres Ring rejected what they called "liberal humanitarian world citizenship." Similar to the DHR in form, but not necessarily in content, the society held education weeks, assemblies, and lectures on issues like national minorities, reform, democracy and dictatorship.

The Görres Ring differed from the DHR, in that its members pledged themselves to Christian organic reform and rejected political views explicitly contrary to Catholic natural law. As reported in the CV's Academia in July 1926, members of the Görres Ring had united

\footnotetext{
28 Von iur. Seissert, RFb, "Zum Kampf um den Hochschulring," Academia 34, Nr. 11/12 (March-April 1922): 261.
} 
out of the desire to work for Germany's "freedom and greatness," but also to affirm the strength of their Catholic beliefs. The Görres Ring generated considerable enthusiasm among Catholics in Cologne, Bonn, and Münster. Ironically, the organization encountered a more tepid response from Catholic students in its birthplace of Munich. Konrad Adenauer, Wilhelm Marx, Felix Porsch, Konrad Beyerle, Heinrich Brauns, and Ludwig Kaas, among others, supported the organization through their membership in the "Friends of the Görres Ring."29

Through most of the Weimar period, nationalism produced a complicated and conflicted relationship between Catholic fraternities and the Church hierarchy. Up to 1933 , the German Catholic Episcopate was divided between two autonomous Bishops Conferences. One met annually at Freising (in the vicinity of Munich) and represented the voice of nine Bavarian bishops. The more nationally influential conference, representing the bishops of Germany's northern and eastern dioceses, met at Fulda. From the standpoint of the Catholic hierarchy, pronouncements from either conference could render a powerful impact on everyday Catholic life. ${ }^{30}$

29 Steinberg, 57. Stitz, 87.

30 Wieland Vogel, Katholische Kirche und Nationale Kampfuerbände in der Weimarer Republik (Mainz: Matthias Grünewald, 1989), 5. 
Germany's clerics were unable to offer a positive appraisal of Germany's situation in the immediate months after 1918. As Hans Peter Bleuel and Ernst Klinnert explain, the hierarchy harbored substantial fears that the November 1918 revolution against the throne could very easily turn into a revolution against the Altar. ${ }^{31}$ The hierarchy also worried openly over the rising influence of German nationalism on Catholic youth. If nothing else, nationalist organizations that were increasingly popular among Germany's youth threatened to lure the next generation of Catholics away from their own confessionally exclusive organizations. 32

In the early 1920s, Cardinal Adolph Bertram, Archbishop of Breslau, reminded his flock that patriotism represented a Catholic religious duty. But Bertram worried about the impact of German nationalism on relations between Germany's Catholics and their brethren in the rest of Europe. Bertram argued that love for the fatherland should mirror respect and consideration for the various peoples bordering Germany. Following the papal encyclical Pax Christi in regno Christi, Bertram agreed with another prominent German Church official who had denounced the spirit of hate against

\footnotetext{
31 Bleuel and Klinnert, 107.

32 Vogel, 41.
} 
neighboring nations as the "heresy of our time." 33 Bertram tried later without success to convince his fellow bishops to issue a letter to Catholic student fraternities to take action against the "infection" of nationalism among the youth. ${ }^{34}$

This was not the first time that Bertram, a Unitas alumnus, had confronted the uncomfortable problem of nationalism. Confirmed by Pius X as Archbishop of Breslau in May 1914, Bertram was able to enjoy his new position for just three months, before Germany entered World War I. Bertram encountered a difficult task as a new Church leader in a diocese with strong ethnic, economic and confessional divisions. As Germany's largest diocese, Breslau (located today in Poland) housed large Slavic and Jewish populations. To complicate matters, relations between Protestants and Catholics were not always on the best of terms, as Till von Rahden's work on the confessional school controversy in the city confirms. ${ }^{35}$ In 1920 , the Unitas journal featured Bertram on its cover, and repeated the warning that the Archbishop had delivered to his flock at the outbreak of wartime hostilities: "Whether German, Pole, Czech, Moravian or Wend, cherish

\footnotetext{
33 Vogel, 41.

34 Vogel, 43.

35 Till van Rahden, "Unity, Diversity and Difference: Jews, Protestants and Catholics in Breslau Schools During the Kulturkampf," in Protestants, Catholics and Jews in Germany, 1800-1914, ed. Helmut Walser Smith (Oxford and New York: Berg, 2001),
} 
your mother tongue. But keep your national hate and aversion away from us. And keep away from us your mutual contempt." 36

\section{Towards a Catholic Theory of Nationalism and National Identity}

In the early 1920 s, professors and other scholars working at German universities called on their colleagues to form working committees to take more assertive and constructive positions on German politics. In response to one such call in 1924, Dr. R. Berger, alumnus of the KV fraternity, posed the following questions:

1. What is understood by the word nationalist ${ }^{37}$ or, who is nationalist and who is not nationalist?

2. What is understood by the word patriotic, including, or specifically in the general German sense? Or, stated more concretely, is it or is it not a patriotic position to constitute the proposed working committee on essentially Christian-Democratic and Republican values?

3. Does the proposed working committee honestly wish to keep political questions out of its activities, or does it believe that patriotic work can be done without taking a specific political position?

4. How far does a German Catholic scholar have to tolerate the accusation of weak national feeling?

\footnotetext{
36 "Dr. Adolf Kardinal Bertram, Fürstbischof von Breslau," Unitas 60 (January 1920),
$61-64$.

${ }^{37}$ For the purposes of this section, völkisch is rendered as "nationalist," and vaterländisch as "patriotic" and Vaterlandsliebe as "patriotism," even if the author admits these translations to be far from reliable.
} 
5. How can German Catholic scholars credibly make their influence heard in a nationalist organization of scholars in the German speaking community?

He continued: "The clarification of these few questions would be very important before many scholars, or at least for me, as a democrat and a republican, can take a position." 38

Berger's article spoke to a number of complicated questions that Germany's Catholics confronted during the years after the Great War. For one thing, the article illustrates the pressures that Catholics working or studying at Germany's institutes of higher education faced by their nationalist colleagues, who were willing to question openly their dedication to the national cause. These same nationalist colleagues likewise alleged that the Catholic confessional worldview contradicted German nationalism and patriotism. The remaining discussion in this chapter will consider how Catholic contributors to the fraternity publications addressed the questions that Berger and his colleagues confronted.

\section{The Nation}

Practically all of the commentators in the Catholic fraternity journals conceptualized the nation, like the state, as a natural, Godgiven entity. At its sixty-first annual assembly held in 1932, the CV

38 Dr. R. Berger "Einigung aller deutschen Akademiker," Akademische Monatsblätter 37 (October 1924): 29. 
affirmed both the Volk and the state as God-willed. The fraternity similarly rejected the idea that the Volk emerged simply from "natural or cultural circumstances." It clarified: "The basis of the Volk is metaphysical. The Volk is a gift from God."39 For this reason, the German nation demanded a Christian pledge of loyalty. As Franz Müller of the Unitas fraternity would write: "God has put no cosmopolitan people or people without community in the world." The national order, he insisted, is God-willed. ${ }^{40}$ At an assembly of Austrian Catholic students held in Vienna in 1932, Dr. Christian Wolf asserted that the nation was rooted deeply in the eternal, religious values of God. ${ }^{41}$ Cardinal Faulhaber, in an address to Germany's Catholic fraternities held in Munich's Löwenbrau Beer Cellar on February 15, 1924, argued that to be German was more than to be born German, just the same as to be Catholic was more than to be baptized Catholic. The Fourth Commandment's admonition to honor one's mother and father, he insisted, obligated the Catholic citizen to obey every law, to

39 "CV und deutsches Volkstum," durch Beschluss der 61. CV-Versammlung wurden hier folgenden Richtlinien für die Arbeit des CV, seiner Verbindungen und seiner Amtstellen auf dem Gebiete der Pflege deutschen Volkstums als volksdeutsches Programm des CV festgelegt. Der entwurf stammt von phil. August Reger, dem Leiter des Grenzlandamtes, Academia 45, Nr. 5 (September 15, 1932): 142-144.

${ }^{40}$ Referat, gehalten auf der 65. G.V. des Unitas-Verbandes zu Duisburg 1928 von Dr. Franz Müller, Karlsruhe (A.H. Deutschritter-Unitas), Unitas 86, Nr. 10 (July 1928): 150-152.

41 Walter Ternik, M-D, "Der christliche Volkstaat," Academia 45, No. 7 (Nov. 15, 1932): 190-191. 
reject every revolution, to pay taxes and to work personally for the welfare of the state and the national community. ${ }^{42}$ In 1926, Erhard Schlund, Lector at the Higher Institute for the Franciscan Order in Munich, and Spiritual Advisor for the CV, ${ }^{43}$ agreed that the Catholic worldview held the nation to be God-given. He likewise instructed that St. Thomas himself had provided the theoretical foundation for establishing patriotism as a Christian virtue. As he explained: "Obligation to practical national work, insofar as this could be described as patriotism, the Catholic Church would affirm as a commandment and a virtue." 44

Many commentators differed, however, on the criteria that defined membership in the German national body. Adalbert Oberthür, a KV alumnus, conceptualized the fatherland as the land of birth, the land of spiritual and physical upbringing and the land made "unforgettable in the thousands of memories of our childhood." In the fatherland, he opined, lived a people united by blood, origins, morality and speech. 45

\footnotetext{
42 "Deutsches Ergefühl und katholisches Gewissen. 23 Thesen Sr. Emminenz des Kardinals Dr von Faulhaber für die katholischen Studenten," Academia 36, Nr. 12 (April 15, 1924): 61-62.

43 The CV was the only Catholic national fraternity organization with a formal spiritual advisor.

44 Erhard Schlund, "Katholizismus und Nationalismus," Academia 39, Nr. 2 (June 15, 1926): 27.

45 Adalbert Oberthür, "Katholizismus und Vaterlandsliebe," Monatschrift des Verbandes der wissenschaftlichen katholischen studentenvereine Unitas 66 (June 1926): 173.
} 
While agreeing with much of this, Berlin Professor Dr. Timpe rejected the idea that blood should define nationhood. In his own definition, Timpe understood a national people to be united through speech and a common spiritual fate. The feeling of "belonging," 46 he countered, could not be mediated through racial unity. The Germans, he reminded his reader (rejecting one false racial paradigm, and in the process, substituting another), hailed from multiple bloodlines with the Slavic being the most prominent. ${ }^{47}$ Dr. Martin Luible of the KV concurred, arguing that there "is no German race." Luible classified the Germans as a culturally unified people, but racially, he argued, they should be divided minimally into three different stocks: a northern, an Alpine and a southern. Luible broke these down further into historically and culturally distinct peoples like the Bavarians, the Swabians, the Franks, the Saxons and the Silesians. ${ }^{48}$ In a speech delivered before the sixtyfifth general assembly of his fraternity in 1928, Dr. Franz Müller of the Unitas fraternity likewise suggested that Germans had defined the concept of Volksgemeinschaft ${ }^{49}$ historically as a national community of blood, or as a genetic community of descent. But he similarly rejected

\footnotetext{
46 Zusammengehörigkeitsgefühl

47 Dr. Timpe, "Volksdeutsche Erziehung des Akademikers," Unitas 67 (October/November 1926): 1.

48 Dr. Martin Luible, "Staat und Volk als Gemeinschaft," Akadem. Monatsblätter Nr. 8 (May 25, 1924): 83-84.

49 Volksgemeinschaft, literally, "people's community." Also a favored rhetorical concept of the nationalist right.
} 
the claim that the German people of his day could be "factually" represented as a racially homogenous entity. 50

In any event, to reduce a person to racial-biological characteristics, argued Müller, violated a fundamental precept of Catholic natural law. Citing a recent lecture given by Romano Guardini at Heidelberg University, Müller reminded his audience that the Catholic Scholastic tradition had held the individual to be a rational substance capable of free will and reason. Race theory must be rejected, he argued, in that it allowed human beings a biologically determined existence only. ${ }^{51}$ To lean on Robert Krieg's helpful analysis, race theory also contradicted Catholicism, as Guardini's conception of natural law would have understood it, by calling on the individual to deny the autonomy of personhood. To appropriate Guardini's reasoning, race theory disrupted the balance between autonomy ("a false assertion of the ' $\mathrm{I}$ ") and heteronomy (placing "authority completely outside of oneself").52 As Müller would conclude, while nationalism required the individual to lean heavily or even exclusively in the

\footnotetext{
50 Referat, Müller, 150-152.

51 Referat, Müller, 150-152.

52 Guardini elaborated on this "theology of personal existence" at the University of Munich after 1948, in part, to offer theonomy, an attempt to reconcile personal autonomy with a common respect for human beings, as a building block for "Christian democracy" that would overcome the failings of both Weimar and the Third Reich. Robert A. Krieg, Catholic Theologians in Nazi Germany (New York and London: Continuum, 2004), 125-127.
} 
direction of heteronomy, Catholic natural law demanded a willed balance between these two poles.

A contributor to Unitas echoed Herder's old claim that each nation, including the German nation, had its own historically appointed task. He defined a Volk as an entity held together by three common beliefs: a belief in itself as a people, a belief in common fate, and a belief in common love.53 Professor Hans Gibl of the KV admitted that the word "Volk" had been assigned multiple meanings. As he conceded: "It is not what the commoners recognize as a nation." The Volk, he continued, could speak to three kinds of community: the natural community of blood and soil; the emotional community ${ }^{54}$ of speech and morals or the spiritual community 55 of common upbringing and fate. ${ }^{56}$ Of these, he concluded, the strongest was to be found in the third. Only through the recognition of spiritual connectedness, he argued, would a Volk truly become a national community. ${ }^{57}$

Some Catholic commentators writing for the fraternity journals were in the habit of drawing sharp distinctions between concepts that more casual observers would have seen as essentially similar or the

53 Festrede von A.H. Plum: "Nun laßt die Glocken von Turm zu Turm Durchs Land frohlocken im Jubelsturm," Unitas 70 (August/September 1930): 11-14.

54 seelisch

55 geistig

56 Bildung and Schicksal

57 Univ. Prof. Dr. Hans Gibl, Wien, "Volk, Staat und Kirche," Akadem. Monatsblätter, 44, Nr. 1 (October 1931): 138-139. 
same. Agreeing with Gibl, Erhard Schlund described as analytically distinct the three critical concepts of Volk, fatherland and nation. The Volk he defined as a community of people of common blood and origins. The fatherland, as he explained in 1926, represented the land in which a people is born, raised and nourished, and on whose soil the history of the Volk unfolds. The nation is part of both of these constructs, but he argued, it also represented something qualitatively different. Schlund defined the nation as that which in the course of history becomes a "community of the total, a living reality of homeland, Volk and statehood." He agreed with his colleagues that the nation also required a spiritual component. In his mind, German national identity was incomprehensible without Christianity. As he explained, “... through Christianity the German blood has developed and through Christianity, the German race has made its most important cultural achievements." Although he sympathized with the more openly nationalist movements on Germany's campuses who sought to ensure the purported "purity" of the German race, Schlund counseled: “... our culture must remain Christian." 58

58 Erhard Schlund, "Katholizismus und Nationalismus," 46-47. Von P. Erhard Schlund, O.F.M., CV-Seelsorger, "Katholik und Vaterland," Academia 44, Nr. 3 (June 15, 1931): 22-23. 


\section{The National State}

Most commentators in the Catholic fraternity journals saw the nation and state as hailing from the same origin, namely, God. Hans Gibl, an Austrian alumnus of the KV fraternity, asserted that in many historical instances the state determined and defined the nation by giving it a specific shape and cultural content. He offered for proof the historical example of the Dutch. Of Germanic origin, Gibl reasoned, the Dutch had become their own people or Volk through the intervention of their state. Following the Dutch paradigm, Gibl asserted that the state alone was able to provide the stability necessary to ensure the making and the maintenance of the nation and its values. ${ }^{59}$ Erhard Schlund agreed that the state, which had a "juridical, political and sociological" nature, should be seen as the "actualized" form in which members of a Volk or a portion of its members were to be brought together on the same ground. But nonetheless, he reminded his reader, nation and state should not be confused. 60

Schlund offered Austria as an example of a state, sovereign in its own right that embodied citizens belonging to a broader German Volk. 61 Along the same lines, Franz Müller presented the example of the

\footnotetext{
${ }^{59} \mathrm{Gibl}$, "Volk, Staat und Kirche," 138-139.

60 Schlund, "Katholizismus und Nationalismus," 27-28.

61 Schlund, "Katholizismus und Nationalismus," 27-28.
} 
Prussian state, which was likewise unable to produce a historically distinct people. Approaching the problem from a different angle, Müller noted that the South Tyrol Germans belonged clearly to the Italian state, and were "doubtless obligated to obey it." But they did not belong to the Italian national community. The Italian state could not change the essential fact that they remained Germans. ${ }^{62}$ His point was that, while the state had the power to overcome human inadequacy, to protect, and to promote the social welfare, unlike the nation, it "had no power over the heart." Only the emotional power of the nation could hold a people together regardless of order, confession or party. ${ }^{63}$

Dr. Martin Luible of the KV addressed the question of the state and its relationship to the nation by turning much further back into history. The coupling of state and nation, he noted, had been a recent development in global history. In antiquity, argued Luible, it was religion that had brought communities together. ${ }^{64}$ This was true for ancient Israel and Egypt, both of which he understood to be a theocracies. Luible was likewise willing to classify the Greeks as a national people. This time, it was their common religious pantheon that held them together. But the fact that the Hellenes never knew a unified

\footnotetext{
62 Referat, Müller, 150-152.

63 Referat, Müller, 150-152.

${ }^{64}$ Here, he does not differ altogether substantially from the early work of Anthony D. Smith.
} 
state, argued Luible, proved his point. On the other side, the Assyrian and Babylonian empires offered the example of the Machtstaat, a state without a nation or even a coherent culture, held together by the naked power of force. This was also true of Rome, once it became an empire. ${ }^{65}$ In contrast to the disorder of antiquity, Luible portrayed the Middle Ages as a time when a single Christian worldview held together the religious, economic, social and political realms that together made up the German nation. Devoid of class hatred, the Middle Ages in Germany represented the time of the "living community." Luible and many of colleagues lauded the Holy Roman Empire of the medieval period as the ideal state form for the German people. Luible, Gibl and other commentators were well aware that the Holy Roman Empire for most of its history had featured a weak central government that exercised only nominal and not altogether effective jurisdiction over powerful local authorities. The only force that held this entity together, at least before the confessional disorders of the 1600 s, aside from the elected Emperor, was not so incidentally, the Catholic Church. 66

Only recently, argued Luible, did the unitary state appear on Europe's landscape to become the primary locus of national identity. Luible charged that the modern state had deified itself, becoming

65Luible, "Staat und Volk als Gemeinschaft," 83-84.

${ }^{66}$ Gibl, "Volk, Staat, Kirche," 138-139. 
Machtstaat and police state all in one. "This is not the beginning of a new time, as certain people want to claim," he argued, "but the end of a state of development." He meant here that with the Germany of his day ripped asunder by class hatred and the opposition of country and city, the state could no longer hold the national community together. ${ }^{67}$

Luible did not stand alone in suggesting that the German state as currently constituted actually harmed the health of the German national community. Concluding his speech to the Unitas general assembly in 1928, Franz Müller argued that a healthy idea, meaning the idea of the nation, could live only in a "healthy body." The German homeland and national community, he contended, must be protected from the "the omnipotence of the state machine," which endangered the holiness of the individual and the sanctity of the family, and threatened to obliterate the bonds of spiritual unity that had formerly tied Germans together. 68

Trying to rebuild a national community through the empty means of law, institutions and force, would fail, continued Luible. This could be accomplished only through a return to the original foundations upon which the German national community was based, namely, the Christian religion. Luible held that this could not be done through a

67 Luible, "Staat und Volk als Gemeinschaft," 83-84.

68 Referat, Müller, 150-152. 
central state power. He countered that the German state should allow the historically centrifugal tendencies in the German nation free play by encouraging a return to federalism, but not, he clarified, separatism. 69 Müller similarly affirmed federalism as a potential solution to Germany's current crisis.

There were a number of reasons why Catholics would be sympathetic to the federalist doctrine. In 1919, the Catholic Center Party had resisted efforts in the Weimar constitutional proceedings to create a more centralized and unitary state, knowing that Catholics enjoyed a numerical preponderance in many regions, but not nationally. ${ }^{70}$ Catholics might also have been thinking of the Holy Roman Empire, a politically decentralized entity held together by the common cultural denominator of Christianity. As this discussion should show, many Catholic commentators looked on the unitary state much less favorably in comparison. Luible and his colleagues might also have been speaking to the inability of the distant central government in Berlin to generate national enthusiasm from the culturally disparate German peoples, who had been accustomed before 1871 to look closer to home to the various regional capitals for political and cultural direction. The essential fact that Berlin could not

${ }^{69}$ Luible, "Staat und Volk als Gemeinschaft," 83-84.

70 Luible, "Staat und Volk als Gemeinschaft," 83-84. 
command the national enthusiasm of most Germans would have been true for the imperial government before November 1918 as well as the Weimar Republic thereafter. ${ }^{71}$

\section{Seeking Accommodation with the Nationalists}

It bears reminding that most of Catholic fraternity commentators worked in a nationalist milieu, especially prevalent on Germany's campuses, which took notice that Catholicism as a belief system held certain values to be nationally transcendent and universal. For this reason, Germany's nationalists charged, Catholics were not to be trusted because they could too easily sympathize and identify with Germany's enemies. This is precisely why many nationalist organizations, the DHR being only the most prominent, tended to treat socialist internationalism and Catholic universalism as essentially the same problem. Dr. Hans Gibl admitted to the problem faced by Catholics when he recalled that the nationalist right had denounced the Church's alleged internationalism. ${ }^{72}$ Cardinal Faulhaber, speaking to Catholic fraternity students in Munich, agreed that rebuilding the fatherland would be nearly impossible if Germans continued to view the Catholic population, and "especially the Catholic student body," as the proverbial "Greeks in Troy," as complicit associates in an international

\footnotetext{
${ }^{71}$ Luible, "Staat und Volk als Gemeinschaft," 83-84.

72 Gibl, "Volk, Staat, Kirche," 138-139.
} 
conspiracy to undermine Germany's national aspirations. ${ }^{73}$ In 1921 , a contributor to the journal of the $\mathrm{CV}$ had to remind his reader that "in the war, we did our duty.... To be Catholic means also to be German."74 In a damning revelation that confessional relations in Germany were far from healthy, the journal of the KV in October 1931 excerpted an article that had recently appeared in a press organ of the DSt. Among other things, the article accused the Pope of being "the direct enemy of the German nation. The article continued: “... any Catholic who recognizes the Pope is likewise guilty of this betrayal." The article went on to charge that the Catholic Church was "internally rotten" and that its older adherents were doomed to take their Catholicism to the grave. As for young Catholics, they still had a chance to break this "empty relationship," but the article warned: "The new youth will take the measure of the Catholic Church, the Jesuits and the Freemasons with a new instrument."75

To counter these charges, some Catholic academics affirmed many of the stock-in-trade components of the nationalist platform, particularly as it related to Germany's foreign policy interests. Like

\footnotetext{
73 "Deutsches Ergefühl...," Faulhaber, 61-62.

74 Von Rob Thieron, RBo, R-G, Kiel, Academia 34, Nr. 5 (July 25, 1921 ): 97.

75 "Die neue Jugend wird alle Organisationen wie katholische Kirche, Jesuiten oder Freimaurertum mit einem neuen Maßstab messen..." "Deutschland und der Papst" (aus einem Organ der D.St.), Akadem. Monatsblätter 44, Nr. 1 (October 1931): 23.
} 
their nationalist cohort, Catholic fraternity writers roundly rejected the Treaty of Versailles imposed on Germany by the victorious Allies in 1919. Among other things, this treaty had held Germany responsible for the outbreak of the Great War, imposed reparations obligations on the new German government, and deprived Germany of its colonies, most of its military assets and substantial territories in Western and Central Europe.

A 1924 article in the KV journal urged its readers to reject the "enemy propaganda" seeking to blame the German government, the general staff, and German industry for starting World War I. It continued: "The Versailles Peace is a peace made by the will of its authors; they set up office as though they were judges looking for the appropriate penalty for our crimes."76 Catholic fraternity students were especially upset that Versailles, insofar as Europe's Germans were concerned, had seemingly violated the privilege of self-determination accorded to other nations. To make matters worse, most of the "Diaspora" Germans - two-thirds by the count of the CV fraternity in 1932 - alienated from the Reich by Versailles were Catholic. ${ }^{77}$ This was true for Alsace-Loraine and also the Saarland, officially still part of

76 "Zur Lüge von unserer Schuld am Kriege," Akademische Monatsblätter Nr. 8, (May 25, 1924): 32.

77 "CV und deutsches Volkstum,”... Beschluss der 61. CV-Versammlung..., 142-144. 
Germany, but under French control until a plebiscite would determine its fate in 1935. Many of the mixed German-Slavic regions awarded to Poland in the 1919 peace settlement were also heavily Catholic. Finally, in following the principle of national self-determination in breaking up the Habsburg domains, the victorious Allies assigned millions of mostly Catholic German speakers to the newly minted states of Czechoslovakia and Austria. Germans were a minority in the former. Although the Allies followed the principle of national self-determination faithfully in creating the latter, German nationalists charged that they had separated Austrian Germans by an artificial boundary from their true home, the German Reich. 78

As early as 1920 , contributors to Catholic fraternity periodicals called on their cohorts to close ranks with German students in Danzig, currently under a League of Nations mandate and left surrounded by the Polish Corridor. ${ }^{79}$ (After 1918, the Catholic fraternity in Danzig continued to belong to the CV.) In 1924 , Unitas ran a headlining article that lamented the alienation of millions of Germans, bound to

\footnotetext{
${ }^{78}$ For once, the paranoia of German nationalism was right. Clemenceau had been particularly keen in reducing the power of the German Reich wherever possible, knowing full well that France would not have the resources to resist it if or when it should revive.

79 "Kartellbrüder! Vergessst nicht die Danziger Hochschule!" Akademische Monatsblätter XXXII, Nr. 11/12 (September 25, 1920): 114.
} 
the fatherland in blood, origin and language. ${ }^{80}$ In June 1928, a contributor to the CV called for a revision of the Versailles Treaty by pointing out that 15 million Germans had been separated from the Reich in Schleswig, East and West Prussia, Danzig, Memel, Poland, Upper Silesia, the Sudetenland, the Tyrol, Alsace and Eupen-Malmedy. In all of these places, in contradiction to the principle of selfdetermination that was supposed to form the basis of the armistice of 1918, the authorities were systematically phasing the German language out of schools, churches and official government business. ${ }^{81}$

The contributor, a Berlin-based member of the $\mathrm{CV}$, singled out Czechoslovakia for especially harsh criticism. He observed that, of all the European states, Czechoslovakia housed the greatest number of Diaspora Germans (3.74 million or $28 \%$ of its entire population). Many of these, as he pointed out, lived in linguistically uniform enclaves along the German border. By making this observation, the commentator implied that the German-Czech border might be altered so as to incorporate these Germans into the fatherland. As he concluded: "Only

80 "Auslandsdeutsche und Auswanderung," Rede des Studiendirektors Dr. Heinrich Timpe, Hamburg (A.H. Unitas-Frisia) auf dem Katholikentag zu Hannover am 2. Sept. 1924, Unitas 65, Nr. 2 (November 1924): 13-17.

81 Von cand. Phil. K. Halsar B-S, Berlin, "Die deutschen Minderheiten in Europa," Academia 41, Nr. 2 (June 15, 1928): 29-31. 
a revision of the peace treaties can make right the injustice done to the German people."82

More broadly, powerfully and perhaps ominously, the $\mathrm{CV}$ at its sixty-first annual assembly held in 1932 stated its official support for the inalienable natural right of the German people in and outside of the borders of the German Reich to self-determination and national unity. At the same assembly, the CV leadership stated its support for the preservation and promotion of the German language and German education, of cultural autonomy, of political and economic independence, and of the autonomy of the social orders of the German people. Although the negotiations preceding the Versailles negotiations had been based supposedly on the principle of self determination of all peoples, the CV complained that the inalienable right of the German people to determine its own national destiny had not been respected or appreciated. Through the "so-called peace treaties" of Versailles and St. Germain, the CV concluded, "18 million of our German national comrades have been forced to live under foreign authority." These Diaspora Germans faced attacks against their speech, against their culture, education and property, resulting in a totally unacceptable situation for which the "peace dictate" should be blamed. The

82 Halsar, "Die deutschen Minderheiten in Europa," 29-31. 
fraternity's leadership concluded that only when the nationality and German minority questions were resolved based on the natural and ethical bases of self-determination would the path be clear for the satisfactory ordering of the European living space. ${ }^{83}$

The Catholic fraternities specifically came out heavily in support of German unification with Austria. With Austria now deprived of its non-German speaking Habsburg legacy, both new governments in Berlin and Vienna contemplated the idea of union in early 1919. Finalized later in the summer, the Versailles Treaty, however, explicitly prohibited such a union. In 1931, Austrian and German leaders tried again to engineer a merger, this time through a customs union. When France identified this as a backdoor attempt to engineer an Anschluß or political union, the two were forced to retreat, but not before banking systems in both states collapsed, further exacerbating the depression that had set in following the U.S. stock market crash in October 1929. In spite of this setback, the KV dedicated nearly its entire June 1932 edition to the question of Austro-German union. Its headlining article insisted that Austria had been part of the German Reich from the time of Charlemagne (c. $800 \mathrm{AD}$ ) to 1866. Any other nation, the article complained, would take for granted the right of 6.5 million of its own

83 "CV und deutsches Volkstum," ... Beschlusse der 61. CV-Versammlung..., 142-144. 
people to live within the same national boundaries. "Austria must not become another neutral Switzerland," it demanded.

Unity is a national goal of all of Germany. Unity requires that Germans come to the recognition that, over parties, economy and state stands the living unity of the Volk, the nation. ${ }^{84}$

Catholic fraternities had a strong incentive to support union with Austria. Unlike the German Reich, Austria was overwhelmingly Catholic. In 1929, nearly one in five of the CV's chapters was located in the Austrian cities of Vienna, Innsbruck and Graz. ${ }^{85}$ Not surprisingly, these very same fraternities came out very heavily in support of a German-Austrian merger. ${ }^{86}$

As demonstrated in Chapter 2, Catholic fraternities denounced the French occupation of the Rhineland, which had been made necessary to ensure that Germany meet its reparations obligations as mandated by Versailles. It was, after all, a CV alumnus, Albert Leo Schlageter, who had been the most revered resistance fighter (and

84 "Der Anschluß ist ein nationales Ziel des Gesamtdeutschtums. Er hat zur Voraußsetzung, das auch wir Deutsche nun zu dem Glauben bekennen: Ueber Parteien, Wirtschaft und Staat steht die lebendige Einheit des Volkes, die Nation." "Unsere Thesen zur Anschlußfrage," Akademische Monatsblätter 44, Nr. 8 (June 1932): 313-314.

85 Of 119 chapters, 87 were in Germany, 23 in Austria, 6 in Czechoslovakia and 1 each in Switzerland, Danzig and Romania. Reichspost (Wien) 36, Nr. 185, (July 7, 1929): 9.

${ }^{86}$ Von Walter Ternik, M-D, Vorsitzer der Arbeitgemeinschaft katholischer Jugendverbände Österreichs, "Vokstum, Reich und Heimat!" Academia 45, Nr. 10 (Feb. 15, 1933): 274-275. 
martyr) against the French economic exploitation of Germany's most prized economic assets. In September 1930, the CV dedicated nearly half of its journal to celebrating the final French withdrawal from the Rhineland. 87

The Catholic fraternities marked this occasion to segue into making broader demands for more Lebensraum or living space for the supposedly overcrowded German nation. As the standard argument went, the fatherland had seen its horizons unfairly constricted by the "victors" peace of 1918. In a 1930 speech, a Unitas alumnus expressed the fear that the German nation "like nations and cultures of the past centuries can sink from proud heights into nothingness." He reiterated the worry that if the Germans remained a "people without space," their national life tree would "no longer be able to grow new branches." 88 As explained in Chapter 5, this vocabulary would be consistent with various Catholic arguments that conceptualized the national community as organic. Many Catholic commentators in the fraternity publications refused to imagine the German nation as being merely the sum of its individual parts.

87 Dr. jur. Udo Krauthausen, Ae, Ministerialrat im Preußischen Ministerium des Innern, "Dem Cartellverband am Rhine seinen Kämpfern für Deutschlands Ehre," Academia 43, Nr. 5 (September 15, 1930).

88 "Festrde von A.H. Plum..." 11-14. 
Speaking before Austrian Catholics in 1932, Dr. Theodor Beiter conceded that the 1919 peace settlements had "injured fundamentally" Germany's relations with other nations. The German people, he argued, "must struggle for living space and simultaneously must demand justice." He also asserted that all German peoples of the same speech were entitled to cultural, economic and political unity under a renewed German Reich.89 A contributor to the 1932 Unitas journal suggested that the economic and financial problems encountered by Germany's students reflected a larger crisis brought on by the alienation of Germany speaking regions from the fatherland, the "tribute" payments demanded by Versailles, and the confiscation of Germany's colonies. He agreed that these problems would be solved only through the acquisition of more living space. 90

Affirming its patriotic credentials, the Catholic Ring in 1931 carried a speech given by a student leader at Trier that, among other things, demanded that the world's powers "take their hands off the German people," retract the lie of war guilt, terminate the reparations debt, and give Germans the room to "live and the air to breath." The

\footnotetext{
89 Walter Ternik, "Der christliche Volkstaat," 190-191. ${ }^{90}$ Richard Hebing (A.H. Unitas-Sugambria), "Akademikernot - Wirtschaftskrise Lebensraum," Unitas 72, Nr. 10 (July 1932): 128-129.
} 
misfortune of Versailles and St. Germain ${ }^{91}$ had torn 11 million Germans from the motherland and their mother people. "Our people," the speaker lamented, "is divided into 17 different states and German communities are scattered all over the world."92

\section{German Patriotism on Catholic Terms}

Much of this sounds eerily reminiscent of the nationalist revisionism promoted by the German National People's Party (DNVP) and more ominously, Hitler's National Socialists. It is little wonder that some commentators would later see the Catholic fraternities and the broader Catholic community as fundamentally similar to the German nationalists on questions of foreign policy and Germany's national interests. This is partly why Gordon Zahn and Guenter Lewy, among others, saw little mystery in the German Catholic Church's later accommodation with the National Socialist regime and its aggressive foreign policy. 93

Most Catholic fraternity writers, however, would have agreed with Christian Wolf, who believed that if Catholics were to articulate an ideology of patriotism and love for the fatherland, they had to do so on

\footnotetext{
91 Referring to the separate 1919 peace treaty with Austria.

92 Festrede, gehalten auf der Reichsgründungsfeier der Trierer Akademiker am 21. January 1931. Von Studienrat Dr. J. Lemmer, Trier (Normanniae), "Volk und Reich," Der Ring 7, Nr. 1/3 (March 1931): 1.

${ }^{93}$ More on this topic will be said in Chapter 7.
} 
terms that were amenable to Catholicism. As Wolf explained, Catholicism obligated his cohort to reject the different national movements of the past century, whether they be socialist, liberal, Protestant, racial, or imperialist. Instead, he insisted, Catholics must base their faith in the German nation on something deeper, namely, the eternal religious values of God. ${ }^{94}$ According to Professor Timpe of the Unitas fraternity, Catholicism demanded an internationalist reformulation of the Golden Rule. Any nationalism, Timpe warned, that "sees relationships among the many peoples in terms different than what would be valid for an individual people had no place on the Catholic side."95 Erhard Schlund agreed that Catholics must never forget that foreign peoples and nations were the children of the same heavenly Father. Certainly, he agreed "we hate enemies that seek to hurt the fatherland," but he clarified "...we must love our enemies, insofar as they are the children of the same God, and we wish them to come around to the position of being the same citizens of the heavenly Reich."96

The Catholic fraternities usually rejected the word "nationalism" in describing their support for the fatherland. They also rejected the

94 Ternik, "Der christliche Volkstaat," 190-191.

95 Prof. Dr. A. Timpe, Berlin (A.H. Unitas-Göttingen), "Vaterlandsliebe und Pazifismus," Unitas 66, Nr. 2 (Nov. 1925): 25-27.

${ }^{96}$ Schlund, "Katholizismus und Nationalismus," 29. 
word völkisch that was preferred by their nationalist cohorts. Instead, Catholics opted for a term that in the German language translates literally into "love of the fatherland."97 As Erhard Schlund explained, love of the fatherland differed from nationalism in that as a virtue, the former required understanding and will. Following the encyclical precedents of Diuturnum (1881) and Immortale Dei (1885), both authored by Leo XIII, Schlund argued that patriotism must be justified by reason. He defined patriotism as a conscious and informed awareness of belonging together in a unity and a community of homeland, Volk and state. In patriotism, he explained, one feels a sense of the fatherland in his or her heart, and is thereby compelled to promote and protect its interests through conscious activation of the will. 98

On the other hand, Schlund rejected nationalism as an "excessive love for the nation." Nationalism, he warned, recognized one nation opposed to all others, without respect to obligation or ethics. In 1926, Schlund wrote that he understood nationalism to be an exaggeration of national feeling in the same way that egoism reflected an exaggeration of self love. As he clarified: "it is to this exaggeration of national egoism that we refer these days when we describe nationalism." Nationalism, 
he insisted, must be prohibited. In its basic concept, he surmised, nationalism stood for a one-sided, extreme manifestation of the national sentiment that in its very essence contradicted God's world order. It subverted the intention of God towards humanity and the world, which required the Christian believer to see all peoples as a familial community. "National and political fanaticism," he concluded, can never be confused with patriotism. "Love of your own people cannot be equated with hatred towards others."99

Schlund had in mind two dimensions to the problem. On the question of Germany's foreign policy interests, Schlund rejected imperialism and pan-German sentiment, insofar as both sought to "push other people under" in order to accomplish German hegemony in Europe and globally. Domestically, he rejected the völkisch movement because of its anti-Semitism. Schlund did sympathize with Germany's nationalists in their desire to "alert people" to the allegedly inordinate influence wielded by Jewry in Germany and worldwide. Schlund rejected, however, the idea that Jews should be targeted "solely based on their race" as the sympathizers to the völkisch movement evidently intended. To anticipate his theological rejection of National Socialism (to be explained in Chapter 7), Schlund also denied that the Old

\footnotetext{
${ }_{99}$ Schlund, "Katholizismus und Nationalismus," 27.
} 
Testament, as a historically Jewish document, should be removed from the Church's canon, as some of his Protestant counterparts were at that very moment demanding. 100

Catholic fraternity writers tended to deploy the friend/foe paradigm when comparing their patriotism with the visions articulated by other nationalists on Germany's campuses. In 1920, a contributor to the CV's journal wrote that "our enemies inscribe nationalism on their flags." He reminded his reader that every nation had its good and bad qualities, and in order for Germans to be a "good nationality," in order for them to take their rightful place in the concert of nations, it was more important for Germans to "fulfill their obligations and work, not talk." As he instructed, "Productivity makes for the best nationalism."101

Along the same lines, Catholic commentators habitually blamed Germany's Protestants as the source of Germany's misarticulated nationalism. One commentator tried to contrast Catholic patriotism with the "racial-nationalist-imperialist" vision, which he attributed to the Protestant concept of authority. He almost certainly had in mind the tendency of Germany's Protestants to equate the birth of the

100 Schlund, "Katholizismus und Nationalismus," 27.

101 "Leistung ist der beste Nationalismus." Von Dr. D. Färber Ch T, Munich, "Nationalismus," Academia 32, Nr. 11 (March 25, 1920): 312. 
German nation with Martin Luther's protest against the Catholic Church in 1517. This decision initiated the bloodiest period in German history, which left the German national body fractured along confessional lines. Contrary to Catholic natural law, Martin Luther was willing to subordinate his new Church to the state, rather than see Church and state as two legally distinct entities. This he did for reasons of Machiavellian pragmatism. Luther availed himself to the protection of Germany's local princes, motivated by selfish reasons of their own, to protect his life and his new religion. In so doing, he made a devil's bargain that propelled the institution of the state in Central Europe to an unnaturally predominant position over the Church.

Centuries later, during the early decades of the imperial period, Germany's Evangelicals had taken advantage of this position to use the state as a launching pad for their "struggle of civilizations" against Catholicism. In their instinctive hostility to Catholicism and its institutions, and their glorification of the national German state, "Protestant powers," the commentator warned "...intend to build a new Germany in which the Catholic Church is shunted off to an unused track." He called on his readers to struggle against the nationalism proposed by the "unchristian" Protestant confession. ${ }^{102}$

102 Eine Theologie des Nationalismus," Unitas 72, Nr. 10 (July 1932): 131-135. 
Catholic commentators in the fraternity journals likewise worried that contemporary nationalism had been driven by the same belligerence that had once targeted Germany's Catholics during Bismarck's war against their Church in the 1870s. In 1921, a contributor to Unitas wrote:

We do not want to dwell in the past, but when we are called to solidarity, then we must first ask if the caller has really torn the mentality of the Kulturkampf from his heart, and has made known freely his intentions. ${ }^{103}$

A contributor to the CV journal expressed similar sentiment in February 1925 when he sought to draw a distinction between the nationalist worldview (which he largely affirmed), and the "nationalist leaders" who tried to steer it into a false direction, thereby becoming the "Kulturkämpfer of tomorrow."104

\section{A Catholic National Rebuilding Project}

In addressing the question of the nation and its relationship with the state, Catholic commentators in the fraternity journals kept with the idea that the Church should stand as a legally distinct entity. Its status would be necessary in order to confirm the Church's right to act as an inculcator of normative values. Along this trajectory, Catholic commentators suggested that the Church and its auxiliary institutions,

103 "Hochschulring deutscher Art," Unitas 61, \#3 (April 1921): 61.

104 Von Reg-Baus. Elimar Hoffmann B-S, Berlin, "Wir und die Anderen," Academia 37, Nr. 10 (February 15, 1925): 128. 
including the fraternities, should educate the German people on how to be genuinely patriotic, using the spiritual ideals of Christianity as a guide. As Erhard Schlund argued, the Christian ethic required more than the simple avoidance of sins. Christian obligation also required the promotion of certain virtues in order to develop more fully the human soul. Schlund held patriotism unconditionally to be one of these virtues. ${ }^{105}$ Professor Ludwig Bahr was thinking along the same lines, when he concluded his address before the KV's Alamannia fraternity chapter by arguing that religious faith held the key to rebuilding and reconstituting the German national community, as it faced crisis after crisis in the years after 1918:

Hold fast on faith. Nothing like faith offers you such security and clear certainty of purpose. No human knowledge of reason, and no individual autonomy or supposed moral self-authority can replace it. Faith makes true men of character. Faith has made the fatherland. Faith must once again rescue us from our misfortune and our turmoil. Never is the national political significance of the Catholic faith and its power to unite the community clearer before our eyes, than today, in the middle of this world catastrophe.

105 Schlund “Katholizismus und Nationalismus," 29. 
Bahr then cataloged the Catholic virtues that he felt would be necessary to rebuild the national community. These included sacrifice, faith in duty, unconditional honesty, humility and modesty. ${ }^{106}$

That Catholicism could contribute to the project of German national renewal was perhaps one of the most intriguing ideas to emerge out of the Catholic fraternity journals during the Weimar period. In making the claim that their Church could revive and establish the German nation on more authentic foundations, Catholics fraternity writers evidently did not allow themselves to be discouraged by their minority confessional status. They were prepared to overlook or overcome the apparent contradiction posed by a Catholic supervised nation building project in a demographically Protestant nation. They were also unwilling to subordinate themselves to Germany's mainstream nationalists of the Protestant or secular disposition.

In 1925, Dr. W. Krausneck, a KV alumnus and Finance Minister of Bavaria, argued that "religion is in the end the true source of patriotism," because it taught the unselfish obligation to serve the neighbor and the general will. This patriotism had nothing to do, he

\footnotetext{
106 Gedächtnisrede auf die Gefallenen. Gehalten in der Trauerkneipe der Alamannia am Samstag, 22. Februar 1919 von Unv.-Prof. Dr. Ludwig Baur (E.M.d.A1.). Akademische Monatsblätter 31 (April 25, 1919): 64-66.
} 
argued, with the "false patriotism, ${ }^{107}$ with the shouts of hurrah," that had often dominated German nationalism. ${ }^{108}$ In 1930, an alumnus of the Unitas fraternity argued that neither economic reform nor a return to war could save the German people or restore it to its inner freedom. He admitted that "we Germans are fated as an especially marked people." German history recorded great deeds, he instructed. But this history also included a legacy of unrest, civil conflict, and disunity. This is why, he conceded, Germany had been and remained the "object" of foreign state interests. For this, the Germans should blame their misconceived nationalism. Too often, Germany had betrayed a national will that oriented towards the dictates of the state, "without respecting the natural rights of the individual and other communities." In belittling the hurrah patriotism of the Kaiserreich, the Unitas contributor held: "We intoxicate ourselves in song and the clang of glasses and call that national feeling."109

The same Unitas contributor believed that the "Catholic state doctrine" and natural law could be used to rebuild the German nation, starting at its most fundamental building blocs, the individual, the

107 Scheinpatriotismus

108 "Festrede zum 60. Stiftungsfest der Walhalla Gehalten auf dem Festkommers vom bayer. Finanzminister Dr. W. Krausneck (A.h.d. Wh. Ast., E.D. Ott. Erw.), Akademische Monatsblätter 37, N. 7 (April 1925): 246.

109 "Festrede von A.H. Plum..." 11-14. 
family and the community. The Catholic worldview, he argued, "requires that the entire life orders itself around it." In his conception, Catholicism structured childhood through the sheltering mechanism of the family, which he characterized as a "living moral organism."110 Catholicism led the individual, he believed, to his or her calling or occupation. Material self interest and the ideology of class, he argued whether from the liberal or socialist bent - were the products of selfishness, and were injurious to the national body. The modern economy had "undressed" the ethos of work, affirmed by the Church in centuries past, from "all its sacral robes." Evidently blaming the formal nature of the German state for this development, he would write: "Has not the life of harmonious one-another degenerated into a struggle of hateful one-against-the-other?"111

In the modern national state, so contributors to the Catholic fraternities believed, egoism had subverted the words "I serve." In stark contrast, the ethos of calling disseminated by the Catholic Church taught the individual to honor the family, to consecrate the value of work, and to subsume ego to the greater good. Erhard Schlund would

\footnotetext{
110 See introduction. CV alumnus Franz-Josef Wuermeling would later argue that the family represented a centrally critical institution in reconstituting West Germany after 1949.

111 Ist nicht aus dem Leben eines harmonischen Miteinander ein Kampf des haßerfüllten Gegeneinander geworden?
} 
opine that, in inculcating the Golden Rule, Catholicism could make individuals aware of their duty to promote the welfare of the entire community against class conflict and class hatred. ${ }^{112}$ Through the teachings of Catholicism, the individual would contribute to the productive strength and the productive will of the national community.

Writing for Academia in 1920, a CV alumnus charged that the sentiment of nationalism had failed the German people and had contributed to its loss in the war and the subsequent chaos that succeeded it. Alternatively, he argued, the German people needed a deeper, more genuine sense of patriotism, which might be disseminated through Catholic Church supervision of confessional education. ${ }^{113}$ Chaplain Riedmatter, writing for the journal of his KV alma mater in 1924, agreed that Germans national feeling had been insufficient to deal with the trauma of the war. Speaking to the inflationary period after the war, he argued that certain people completely lacking in a "spirit of community" had benefited, while totally disregarding the evident human suffering around them. The renewal of the German people, he contended, depended on overcoming such egoism. Catholicism, he argued, and particularly the spirit of the Catholic

112 Schlund, "Katholik und Vaterland," 24.

113 Von Oberlehrer, Dr. Kohnen Rh, Z, Vechta i. "Christlich-National," Academia 33, Nr. 5 (20. September 1920): 117-118. 
fraternities, would be ideal vehicles for mediating this overcoming and this renewal. Community, as Catholicism taught, is the "joy of sacrifice." This is the first principle and fundamental basis of Catholic religiosity, he contended, quoting 1 Corinthians 13:1-4:

Love is patient, love is kind. Love does not envy. Love is not pompous. Love is not inflated. It is not rude, it does not seek its own interests, it is not quick tempered, it does not brood over injury, it does not rejoice over wrongdoing but rejoices with truth. It bears all things, believes all things, hopes in all things, endures all things. Love never fails. ${ }^{114}$

This should be the principle, he reminded his reader, whereby young pledges should be educated through their participation in the fraternity. Fraternity members would likewise come to the understanding that the lessons of their learning years would be applied to the welfare of the national community. Through their leading role, the principle of Corinthians would form the basis on which a more authentic national community could be built. In the past months, Reidmatter had come across numerous written works promoting the concept of national community. Riedmatter retorted that this was all merely theoretical, not true patriotic praxis. He concluded that a Catholic fraternity member who understood truly the values of friendship and love should

114 The New Catholic Bible (1969) (p. 1297) is relied on in part for this translation, with the variations in the German rendition, insofar as possible, preserved. 
have no problem contributing to this community's rebirth and renewal. ${ }^{115}$

Affirming a claim by Catholic theologian Joseph Mausbach, Professor Timpe asserted that "love of one's people is not just a natural ground of experiential fact, but it belongs to a higher ethical value, that must be promoted from the religious point of view." Like many of his Catholic cohort, Timpe rejected a revisionist war against Germany's enemies. But he believed that a spiritual struggle could liberate Germany and restore its rights, in part, through a moral renewal of the German people. On the domestic front, Timpe had very specific goals in mind, including efforts to combat pre-marital sex, alcoholism, political corruption and economic materialism. More broadly, he argued that on the international front, the Reich should promote an "offensive of high cultural achievement" on behalf of the world's cultural community of 100 million Germans. In so doing, Germans could struggle against the "systematic lies" of "national hate and pride," that were the legacy of the Great War and the Versailles peace settlements. They would thereby finally secure international respect for Germany's inalienable rights. ${ }^{116}$

\footnotetext{
115 Kaplan V. Riedmatter, Hauenstein-Pfalz, "Unsere drei Prinzipien als Erzieher zur Volksgemeinschaft," Akadem. Monatsblätter 37, Nr. 1 (October 1924): 60-62.

116 Timpe, "Vaterlandsliebe und Pazifismus," 25-27.
} 


\section{Conclusion}

In a 1922 issue of Academia, Walter Bloem promulgated "Ten Commandments" for the German student. The link between Catholic thinking and patriotism, as Bloem drew it, is instructive. The first commandment linked the admonition to refrain from taking the Lord's name in vain with the idea that a willingness to die for the fatherland should not be expressed in great public pronouncements. As Bloem explained, "It is pointless to rattle a fork that is no longer there. Learn to be quiet!" National survival depended on circumspection. It may be a not altogether unreasonable stretch to surmise that what Bloem really had in mind was Jesus' criticism of his contemporary "hypocrites" who stood and prayed "in the synagogues and the street corners so that others may see them."117 True German patriots, to carry this reasoning further, need not go through the obligatory but spiritually empty public motions of nationalism. They might be able to affirm their national loyalty in the "inner room" of their consciousness, so to speak, working for the fatherland quietly without concern for approval or reward.

The next commandment instructed the fraternity student to be "mindful of the sufferings" of the German people. Bloem instructed his young readers that "millions" of their comrades were suffering, all the

117 Matthew 6: 5-8 (The New American Bible, 1978). 
while as foreign powers occupied entire German speaking states and provinces. As a result, "hundreds daily" were seeing their "German identity compromised."

Bloem likewise commanded his fraternity readers to rise above class, race, politics and confession in order to prove their worth as strugglers for "the rebirth of our people." Bloem similarly instructed his readers to "know the history of your people, especially the history of the German student body." Bloem instructed fraternity students to live an "exemplary life," which meant that they should avoid alcohol and prostitution, both of which damaged the nation's health as well as the ability of its young to procreate. He also admonished his readers to "engage in matters of technical need." At the same time, they should avoid "any foreign luxury goods" including tobacco, cigars, coffee, tea, foreign wine and liquor. In what should come as no surprise to a college instructor of any recent century, Bloem felt compelled to remind his readers at the end of his list of commandments that they "should study."118

118 Walter Bloem, "Zehn Gebote für den deutschen Studenten," Academia 35, Nr. 1/2 (May-June 1922): 9-10. 


\section{Chapter 7}

\section{The Catholic Fraternities and National Socialism}

Against every heresy, against every "-ism" in social and public life... Catholic thought reacts with a sharp barrier.... All radicalisms work in cheap black and white techniques they are all basically negations, they love primitive claims, uncomplicated realities, and catch phrases. They prefer "Eros" and "pathos" not "ethos" and "logos." Prof. V. Tischleder, KV fraternity alumnus, $1931 .^{1}$

Adolph Hitler, as the legions of his biographers on both sides of the Atlantic know, was baptized and confirmed as a Catholic. So too were some of the most important auxiliary figures in his regime, including Heinrich Himmler, Reinhard Heydrich and Joseph Goebbels. ${ }^{2}$ Among these, Goebbels had at one time belonged to the Catholic Unitas fraternity. The future Propaganda Minister of the Third Reich pledged the fraternity's Sigfriedia Bonn chapter in 1917, at a time when most of its members were at war. According to biographer Ralf Georg Reuth, Goebbels took happily to its "great, masterful drinking fests," and its "merry excursions into the great expanse of the beautiful German countryside." The student of art, drama, philosophy and literature also

\footnotetext{
1 Prof. Dr. V. Tischleder, Münster, i.W., "Der katholische Staatsgedanke als Echo der ursprünglichen gefundenen katholischen Wesensmitte," Akadem. Monatsblätter, 44, \#1 (October 1931): 120-126.

2 Richard Steigmann-Gall, The Holy Reich: Nazi Conceptions of Christianity, 1919-1945 (Cambridge: Cambridge University Press, 2003), 133.
} 
found the time for serious pursuits. ${ }^{3}$ While the war was still on, Goebbels delivered a speech on religious art at a fraternity function. Prelate Wilhelm Neuss, a local Church official in attendance, later remarked that the young Goebbels had given the best talk on the subject he had ever heard. This was the same Neuss who in late 1934 anonymously helped to author a widely circulated church pamphlet denouncing Alfred Rosenberg, seen by some observers as the single most significant ideological voice of Hitler's regime. ${ }^{4}$

Like many Germans of his cohort, Goebbels changed universities about as often as today's American college students change majors. From his starting point at Bonn, he transferred to Freiburg. In this scenic Black Forest town nestled in the southwestern corner of Germany, Goebbels reportedly ran afoul of the local authorities by engaging in disorderly behavior at a peasants fair. ${ }^{5}$ Goebbels then transferred to Würzburg. ${ }^{6}$ It was after his first semester at Würzburg that Goebbels resolved to leave the Unitas fraternity. As Reuth tells us, he resigned from his fraternity after missing Midnight Mass on

\footnotetext{
${ }^{3}$ Ralf Georg Reuth, Goebbels (San Diego, New York and London: Harcourt, Brace \& Company, 1993), 21.

${ }^{4}$ Hans Jürgen Rösgen, Die Auflösung der katholischen Studenten Verbände im Dritten Reich, Dortmunder Historische Studien, Bd. 15 (Universitätsverlag Dr. N. Brockmeyer, 1995), 58-60. Guenter Lewy, The Catholic Church and Nazi Germany (Da Capo Press, 1964, 2000 paperback edition used here), 153 and 372.

5 Rösgen, 61.

${ }^{6}$ Bonn, Freiburg and Würzburg typically had substantial Catholic enrollments. The Catholic fraternities were active at all three of these universities.
} 
Christmas Eve, 1918, for the first time in his life. ${ }^{7}$ Devastated by Germany's loss in a war experience denied to him because of a congenital infirmity, Goebbels, like thousands of other young Germans at the time, searched elsewhere for his directional star.

\section{The Emergence of National Socialism on Germany's Campuses}

After his National Socialist Party rose from its meager beginnings to national prominence in the early 1930 s, Adolf Hitler proclaimed that nothing had confirmed to him the righteousness of his cause more convincingly than the early victory of National Socialism on Germany's college campuses. ${ }^{8}$ Jürgen Schwarz claims that most of Germany's students in the early years of the Weimar Republic inclined themselves to the nationalist, anti-democratic and anti-Semitic ideas that were the stock in trade of Hitler's platform. ${ }^{9}$ Many, but not all German students sympathized with anti-Semitic ideologies and claimed as their intellectual forefathers racists like Joseph-Arthur de Gobineau, Paul de Lagarde, Adolf Stoecker, Richard Wagner and Houston Stewart Chamberlain. ${ }^{10}$ Geoffrey J. Giles agrees that racial anti-Semitism

\footnotetext{
7 Reuth, 28.

8 Gerhard Schäfer, "Studentische Korporationen im Übergang zum deutschen Faschismus," 1999 Zeitschrift für Sozialgeschichte des 20. und 21. Jahrhunderts 3 (1988): 116.

9 Jürgen Schwarz, Studenten in der Weimarer Republik: die deutsche Studentenschaft in der Zeit von 1918 bis 1923 und ihre Stellung zur Politik (Berlin: Duncker \& Humblot, 1971), 17.

${ }^{10}$ Schwarz, 344
} 
struck a powerful resonance chord on Germany's campuses in the 1920s. ${ }^{11}$ As we know from Chapters 3 and 6, many of Germany's fraternities had already adopted anti-Semitic membership clauses in their constitutions by the early 1920 s. ${ }^{12}$ Some, in fact, had adopted these racially restrictive membership provisions even before 1914 . Similarly, national fraternity governments all but excluded from student politics Jewish fraternal organizations like the Cartel of Jewish Unions. ${ }^{13}$

At times little more than a political curiosity on Germany's early post-World War I national scene, Adolf Hitler made significant inroads on Germany's student body early in his career. On May 17, 1923, Hitler spoke on a college campus for the first time to highly supportive fraternity students at Erlangen. In the aftermath of the failed 1923 Putsch, pro-Hitler demonstrations in Munich forced the rector to close the university for several days. ${ }^{14}$ These very same students, as

${ }^{11}$ Geoffrey J. Giles, Students and National Socialism in Germany (Princeton: Princeton University Press, 1985), 18-19.

${ }^{12}$ Michael Stephen Steinberg, Sabers and Brown Shirts: The German Students' Path to National Socialism (Chicago, 1973), 6.

13 Perhaps surprisingly, only the very elite corps, the Kösener Seniors (supplier of twenty percept of Prussia's senior civil servants in 1928), for instance, hesitated to incorporate the anti-Semitic statutes that had become the norm in other fraternities. Remarkably, as late as 1935, well after Hitler's seizure of power, the Kösener Seniors refused to break their ties with Jewish alumni. Giles, 18-19.

14 Giles, 26-27. 
described in Chapter 3, openly declared their hostility to Catholicism and Munich Archbishop Cardinal Michael von Faulhaber.

In 1926, two Munich students, Wilhelm Tempel and Helmut Podlich formed the National Socialist German Student Union (NSDStB). The new National Socialist union shared with the dueling and nationalist fraternities a strong opposition to the republic. At times, however, the National Socialists insulted the elite consciousness of the dueling fraternities by promising social equality to all Germans. Otherwise, the National Socialist union incorporated many of the standard right-wing student demands into its platform. The National Socialists advertised themselves as the defenders of university autonomy (so as to protect the university from liberal and socialist state authorities) and sponsored forums and speakers on political questions. The organization demanded changes in university curricula, and called for the introduction of national values into the university system. As a Hitler victory in Germany's parliamentary elections seemed increasingly likely in 1932, the organization called for the abolishment of student democracy in favor of the leadership principle. ${ }^{15}$

Remarkably and disingenuously, the NSDStB and its nationalist allies redeployed the traditional call for academic freedom so as to

\footnotetext{
15 Rösgen, 37-38.
} 
justify their attacks against allegedly "left-wing" teachers of partisan causes. After 1925, students complained unfairly and inaccurately that Germany's intellectuals were using their lecture halls as pulpits to impose the values of a liberal socialist state. ${ }^{16}$ Organizations like the German University Ring (DHR) ${ }^{17}$ and the German Dueling Ring, by that time strongly linked to anti-republican political parties, coordinated attacks against allegedly pacifist and republican scholars. These attacks, often motivated strongly by anti-Semitism, included public denunciations and boycotts. In Heidelberg, through loud protests and disruptive behavior, students forced the theology department to retract its offer of appointment to Günther Dehn. This decision came in spite of counter-protests from twenty-seven prominent Heidelberg professors. Dehn tried again to teach at Halle. When the same attacks came this time from the NSDStB, the Academic Senate reacted by dissolving the organization. ${ }^{18}$ The NSDStB and its allies also harassed Emile Julius Gumbel at Heidelberg. Known as a pacifist, Gumbel fell victim to a sustained student campaign that led ultimately to his dismissal. He eventually emigrated from Germany. NSDStB members also exerted

\footnotetext{
${ }^{16}$ According to Steven P. Remy, Germany's professors leaned to the right and shared their students' antipathy towards the Weimar republic, even if they did not share their desire to overthrow it. Steven P. Remy, The Heidelberg Myth: The Nazification and Denazification of a German University (Cambridge and London: Heidelberg University Press, 2002).

17 Deutscher Hochschulring

18 Rösgen, 23.
} 
pressure on another pacifist, Theodor Lessing, a theologian at Hanover. Student agitation led to boycotts of Lessing's lectures, and the theologian eventually fled to Czechoslovakia, where he was later murdered by the Sudeten German SS in Marienbad. In Munich, students heckled law teacher Hans Nawiesky as a Jew and a representative of parliamentary democracy. National Socialist students in Leipzig also harassed and ultimately drove from the university economics professor Gerhard Kessler, who had openly criticized Hitler. ${ }^{19}$

Advertising themselves as the enemies of Marxism and the true defenders of the German nation, National Socialist students enjoyed increasing popularity on Germany's campuses in the late 1920s and early 1930 s. ${ }^{20}$ In 1928 , membership in the National Socialist student union skyrocketed up ninety percent over the previous year. ${ }^{21}$ By the summer of 1931, an even stronger proportion of the German student body inclined towards National Socialism, although there is some dispute on the actual number, with Kater claiming as much as sixty percent, while Gladen and Giles arrived at much lower (but still

\footnotetext{
19 Schäfer, 116.

20 Steinberg, 7.

${ }^{21}$ Rösgen, 26-27. Remy points out that Germany's professors did not necessarily share student enthusiasm for the National Socialists. Nonetheless, after Hitler came to power in 1933, most of Germany's professors were willing to adapt to or accommodate his new regime. Remy, 22.
} 
impressive) figures of thirty percent. ${ }^{22}$ The National Socialist Student union received its highest support in the smaller university towns, for instance sixty-three percent in Marburg and sixty-two percent in Tübingen. Predictably, the organization received smaller support, less than twenty percent, in bigger cities like Dresden and Hamburg. Nonetheless, by 1932, the National Socialist student union represented the third strongest organizational presence on German campuses, trailing only the nationalist $\mathrm{DB}$ and the Catholic CV fraternities. By 1932, the National Socialists and the broader nationalist block received a two-thirds majority in the associated German student body elections. ${ }^{23}$

\section{National Socialism and the Catholic Hierarchy}

As Catholic fraternity publications pointed out repeatedly, fraternity students respected and deferred to Germany's Catholic bishops on crucially important questions pertaining to doctrine and politics. This was true concerning the emergence of National Socialism around 1930. As the Catholic CV confirmed at its sixty-first national assembly in 1932, Germany's Catholic bishops

... have the right, in all points of belief and ethics to determine what Catholicism is. They also have the right to determine what worldview or political direction is consistent

\footnotetext{
22 Rösgen, 26-27.

23 The German acronym is AstA. Rösgen, 26, 38-42.
} 
with the position of the Catholic Church. They have the right, in individual cases or generally to place prohibitions against certain powers. ${ }^{24}$

The CV alumni likewise believed that Germany's bishops had the authority to provide determinative guidance to the Catholic fraternities on the question of National Socialism. ${ }^{25}$

According to Guenter Lewy, Germany's bishops remained implacably hostile to Hitler before he came to power in 1933. In 1931, Bishop Ludwig Maria Hugo of Mainz upheld the decision of a local priest in his diocese to prohibit Catholic membership in the Nazi party, to deny Nazi party members access to the sacraments and, in the highly publicized case of Nazi party district Chief Peter Gemeinder, to refuse even the right to a Catholic burial. ${ }^{26}$ Prominent clerical opponents of Hitler also included Berlin's first bishop, ${ }^{27}$ Christian Schreiber, who called on Catholics to reject National Socialist racism and to transcend "all differences of parties, of weltanschauung, of race and religion." An honorary member of the CV fraternity, Schreiber originally found promise in National Socialism, particular its appeal for German national renewal. In 1931, he encouraged the CV to retract its ban on National

24 "Die Beschlüsse der 61. CV-Versammlung, zusammengestelt von Dr. Hermann Hagen, Th, München, Academia 45, Nr. 6 (September 15, 1932): 137-138. 25 "CV and Nationalsozialismus," Academia 44, Nr. 12 (April 15, 1932): 333. ${ }^{26}$ Michael B. Lukens, "Joseph Lortz and a Catholic Accommodation with National Socialism, in Betrayal: German Churches and the Holocaust, ed. Robert J. Ericksen and Susannah Heschel (Minneapolis: Fortress Press, 1999), 150.

${ }^{27}$ Prior to World War I, Berlin had been administered by the archdiocese of Breslau. 
Socialist membership. A disappointed Schreiber reversed this recommendation less than a year later, after concluding that National Socialism sought to replace Christianity with a religion of its own. ${ }^{28}$

Highly placed clerical opponents of Nazism were also to be found in the Bavarian bishops' conference in Freising, chaired by Munich Archbishop Cardinal Michael von Faulhaber. On February 12, 1931, Faulhaber declared that National Socialism adhered to a religious and cultural program that was "irreconcilable with Catholic teaching." 29 The Bavarian bishops were joined in August 1931 by their counterparts in Prussia and Northern Germany. Under the leadership of Breslau Archbishop Adolf Bertram, these high clerics at their conference at Fulda determined that: "National Socialism actually stands in the most pointed contradiction to the fundamental truths of Christianity and with the institution of the Catholic church created by Christ." 30

Among other things, Germany's Catholic bishops were well aware of the hostile attitude demonstrated by Hitler and his followers towards the Catholic Center Party, the Catholic hierarchy, and the deeply layered Catholic auxiliary institutions that continued to structure the

\footnotetext{
${ }^{28}$ Kevin P. Spicer, Resisting the Third Reich: The Catholic Clergy in Hitler's Berlin (Dekalb: Northern Illinois Press, 2004), 18, 124.

${ }^{29}$ Lewy, 9.

${ }^{30}$ Robert A. Krieg, Catholic Theologians in Nazi Germany (New York and London: Continuum, 2004), 2.
} 
lives of millions of Catholics across Germany. Claudia Koonz reports that in 1928, Hitler devoted two speeches of approximately 2-3 hours length (a total of 47 printed pages) combining anti-Semitic and anticlerical humor. ${ }^{31}$ Germany's bishops were also alarmed by National Socialist racism, which seemed to suggest that moral laws and ethical codes of conduct were specific to a particular national body, rather than valid at all times, for all people in all places, as Catholic natural law had long held. Along a similar vein, Germany's bishops also worried about the excesses of Hitler's nationalism. ${ }^{32}$

Germany's Catholic authorities were ill at ease with Article 24 of the original Nazi program. Formulated in 1920 when the NSDAP was still the tiny German Worker's Party (DAP), Article 24 offered to guarantee religious freedom in Germany, but only insofar as Germany's various confessions and denominations did "not militate against the morality and moral sense of the Germanic race." This doctrine was known in National Socialist nomenclature as "positive Christianity." Hitler never redacted this article from the party program, even after his

${ }^{31}$ Claudia Koonz, The Nazi Conscience (Cambridge and London: The Belknap Press of Harvard University, 2003), 25-26. Steigmann-Gall offers a more nuanced portrayal, noting that Hitler often tempered his public hostility to the hierarchy out of political considerations. Nonetheless, even in his narrative, Hitler's hostility and contempt for the Catholic Church is in evidence. In particular, the "positive" Christianity" contemplated by Hitler would be overwhelmingly Protestant in content, as Hitler believed the Protestantism had done a much better job of strengthening the German national state and defending German national honor. Steigmann-Gall, 62-63. ${ }^{32}$ Lewy, 9. 
party changed names and tempered much of its initially socialist sounding rhetoric in the late 1920 s and early 1930 s.

Following a long trajectory of nationalist thought dating back to the Kulturkampf, many National Socialists hoped that Germany's confessional division might be overcome through the national renewal promised by Hitler. Such an outcome could not bode well for Germany's Catholic Church. As historian Kevin Spicer points out, the creation of any national church in Germany would jeopardize the most crucial mission of the Catholic hierarchy, namely, to be the sole guardian of scripture, doctrine and teachings on morality for Catholic followers. Bishop Schreiber in particular worried that National Socialism would seek to offer a new religion to replace the existing churches. Schreiber likewise denounced positive Christianity as "dogmatically empty."33

Germany's Catholic bishops and officials working for their subsidiary hierarchy found troubling a number of specific ideas articulated by National Socialist party officials both before and after Hitler came to power in 1933. At the top of their list stood Alfred Rosenberg's The Myth of the $20^{\text {th }}$ Century, which found its way onto the

${ }^{33}$ Spicer, 8, 18. 
Vatican's Index of Forbidden Books in 1934.34 Germany's clerics were willing to criticize this book even after Hitler came to power and clamped down hard on Germany's press freedoms in 1933. In 1935, the vicar general's office of the Berlin diocese published an academic study of Rosenberg's book that included four unsigned articles (including the above-mentioned article authored by Prelate Neuss). ${ }^{35}$ Among other things, these anonymous contributors criticized Rosenberg's "heathen nationalism." They charged that Rosenberg proposed to substitute a community of blood in the place of all universal moral and ethical values. The contributors to this diocesan pamphlet also criticized Hitler's supporters (as well as a number of prominent contemporary Protestant theologians) ${ }^{36}$ who had tried to argue that Jesus hailed from Aryan, not Jewish origins and who had also called for the removal of the "Jewish" Old Testament from the "Christian" Bible. ${ }^{37}$

The contributors to this 1935 pamphlet countered that Catholics could not forget the essential role played by the Jews as God's chosen people. Likewise, they insisted, the story of Christ as the savior and

${ }^{34}$ Remarkably, none of Hitler's publications was ever listed on the Index, and Hitler was never excommunicated from the Church. He remained a formal member of the Catholic Church until his death. Lewy, 152.

35 Including from Neuss; see introductory remarks at the beginning of this chapter.

${ }^{36}$ Robert P. Ericksen, Theologians under Hitler, Gerhard Kittel, Paul Althaus and Emanuel Hirsch (New Haven and London: Yale University Press, 1985).

37 Spicer, 124-125. 
redeemer would be incomprehensible without the illuminating prophesies of the Old Testament. To reject the Old Testament or to revise the story of Jesus' racial origins, as Hitler's movement seemed to demand, would contradict the fundamental law and teachings of the Church. ${ }^{38}$

Richard Steigmann-Gall has recently sought to minimize the importance of Rosenberg to Hitler's movement. Rosenberg's writings were standard faire in the Hitler Youth, among other auxiliary National Socialist organizations. But in one of his more politically circumspect, if characteristically manipulative moments, Hitler tried to reassure Germany's Catholic bishops after 1933 that Rosenberg did not stand for the party officially as far as religion was concerned. In private moments, according to Albert Speer, Hitler ridiculed Rosenberg as "narrow minded" on the question of religion and religious belief. More bluntly, Joseph Goebbels wrote off the Myth of the $20^{\text {th }}$ Century as an "ideological belch." 39 In any event, thinking in pragmatic, but not necessarily ideological terms, Hitler believed firmly that any frontal assault against the Catholic Church along the lines of either the Kulturkampf or Georg von Schönerer's Pan-German movement in his native Austria was bound to fail. In the short term, Hitler and most of

38 Spicer, 124-125.

${ }^{39}$ Steigmann-Gall, 93. 
his followers recognized that Catholicism was entrenched too firmly in the German population to be dislodged easily. 40

Nonetheless, as Hitler's movement gained momentum in the early 1930s, Germany's Catholic leadership remained apprehensive.

Germany's Catholic bishops were well aware that Hitler promised the overthrow of Weimar and the subversion of German democracy. Given the notable hostility expressed by most of Germany's bishops towards the Weimar Republic, this was an outcome with which they could presumably live. (This would have also been true for a substantial portion of the Catholic population.) Three bishops from the Church's Paderborn province on March 10, 1931 reminded their flock, however, that National Socialism encompassed more than a political party. In their minds, Nazism also represented "a total world outlook." As such, it involved "an attitude towards religion and it poses demands in the area of religion." 41

Germany's clerics worried in particular that National Socialism might try to undermine or reconstitute Germany's school system, which in spite of the ambivalence of the Weimar constitution, continued to allow for religious education in the classroom. National Socialism had also opposed the various state concordats or treaties consummated

40 Steigmann-Gall, 61-62.

${ }^{41}$ Lewy, 11. 
between the Vatican and a number of Germany's constituent states. ${ }^{42}$

In the words of Ronald Warloski, historian of the "New Germany"

Catholic fraternity movement that thrived in Germany's secondary

schools during the Weimar years, Germany's clerics argued before 1933

that National Socialism posed a "mortal danger in that it did not

basically oppose lying and murder as a means to an end." ${ }^{43}$ Many of

Germany's bishops feared that, with a vast auxiliary apparatus of its

own, National Socialism might deprive German Catholicism of its prized

network of youth organizations, including both its secondary school and

university fraternities, which were seen as so essential to transmitting

the values of Catholicism to the next generation. ${ }^{44}$

On August 5, 1931, Germany's northern clerics met in Fulda.

Setting an exceptional precedent, Cardinal Faulhaber attended the

meeting as a representative of Bavaria's bishops. During their

deliberations, Germany's bishops drafted the prophetic statement that

42 This included Bavaria in 1924, Prussia in 1929, and Baden in 1932. Winfried Becker, "Kirche und Staat. Anzätze zur Neubestimmung ihres Verhältnisses in der Kultur- und Konkordatspolitik der Weimarer Republik," Zeitschrift für bayerische Landesgeschichte Bd. 49, Heft 1 (1986): 175. A Concordat between the Vatican and the national government in Berlin had long been a cherished goal of both the Vatican and Germany's bishops. Under both the Kaiser Reich and Weimar, this had proved impossible.

${ }^{43}$ Ronald Warloski, Neudeutschland, German Catholic Students, 1919-1939 (The Hague: Martinus Nijhoff, 1970), 136.

${ }^{44}$ In addition to Warloski, see Wieland Vogel, Katholische Kirche und Nationale Kampfverbände in der Weimarer Republik. Veröffentlichung der Kommission für Zeitgeschichte. B. 48. (Mainz: Matthias Grünewald, 1989), 93-95. 
Hitler and his movement pretended "... to be no more than a political party with justified national goals," but in fact stood in "clearest conflict with the fundamental truths of Christianity." As they concluded:

.... the issue is not one of blunders by individuals but rather the overall-effect of pronouncements and events which determine the character of the party. In the face of these, occasional denials are of no significance..$^{45}$

Guenter Lewy writes that, under Bertram's direction, the conference opted for a watered down statement, which did not single out National Socialism by name, but simultaneously condemned extreme nationalism, socialism and communism. ${ }^{46}$

\section{National Socialism and Germany's Catholics}

Many prominent and ordinary German Catholics went to great lengths to oppose Hitler's movement, and later, Hitler's regime. Even John Cornwall, known for his searing condemnation of the Vatican and its refusal to act effectively in the face of the Holocaust, admits that German "Catholic criticism of the National Socialists was vehement and sustained in the press and from the pulpits." In particular, Cornwall points to Fritz Gerlach, a writer for the Munich based publication, The

\footnotetext{
45 Lewy, 13.

${ }^{46}$ Lewy, 13.
} 
Correct Path, ${ }^{47}$ who on June 21, 1932, characterized National Socialism vividly as a plague, and argued that:

National Socialism means enmity with neighboring countries, despotism in internal affairs, civil war, and international war. National Socialism means lies, hatred and unbounded misery. Adolf Hitler preaches the law of lies. You have fallen victims to the deception of one obsessed with despotism, wake up!48

As Robert A. Krieg writes, only one out of seven Catholics voted for the National Socialist party in 1932 (as opposed to two out of five Protestants). 49 Even through World War II, in the "black" 50 villages of Bavaria and Westphalia, National Socialists remained, in the words of Carl Amery, a "hopeless minority." 51 Hitler's youth movement remained weak precisely in those areas where Germany's Catholic competitors were strongest, Bavaria, the Rhineland and parts of Silesia. ${ }^{52}$ Hitler's victory in 1933 did little to redress this disparity in support. As the leadership of the SS testified in late spring 1934, after Hitler had been in power for over a year, there was "no recognizable crumbling" of the Catholic youth front. 53

\footnotetext{
47 Der Gerade Weg

48 John Cornwall, Hitler's Pope: The Secret History of Pius XII (New York: Viking Penguin, 1999), 108-110.

${ }^{49}$ Krieg, 3.

50 The historical color of German Catholicism.

51 Carl Amery, Capitulation: The Lesson of German Catholicism (New York: Herder and Herder, 1967), 66-67.

52 Steigmann-Gall, 213.

53 Warloski, 158.
} 
In early 1933, Francis P. Stratmann, chaplain to students in Berlin and head of the Catholic Peace Union, wrote a letter to Cardinal Faulhaber, lamenting that "the souls of the well-intentioned are deflated by the National Socialist seizure of power." 54 At around the same time, a writer for a Catholic periodical wrote: "we are convinced that Hitler represents the incarnation of evil."55 In December 1933, Cardinal Faulhaber delivered a series of advent sermons reminding his flock that God had trusted his word to the Jews as his chosen people, thereby preserving the cultural bond between Judaism and Christianity. Less than four years later, Faulhaber played a leading role in drafting the papal encyclical, Mit brennender Sorge ("With Burning Concern"), read from pulpits across Germany in March 1937, which among other things, rejected the idea that the concept of race or Volk could be transposed over the "the scales of earthly values" and make them "the ultimate norm of all things, even of religious values." One who would deify racial or national values with "an idolatrous cult" the encyclical continued, "perverts and falsifies the divinely created and appointed order of all things... is far from true belief in God and from a conception of life in conformity with it." The encyclical reminded Catholic believers

${ }^{54}$ Krieg, 23.

55 Lewy, 21. 
that "God's sun shines on the human race without distinction... His laws know no privileges, no exceptions."56

Historian Michael Phayer believes that "unlike many churchmen in Croatia, Hungary and other eastern European countries," during the 1920s and 1930s, most German Catholic bishops "were not meanspirited towards Jews." 57 Considerable evidence can be marshaled to support Phayer's contention. In November 1938, for instance, Provost Bernhard Lichtenberg in Berlin protested the Kristallnacht pogrom against Germany's Jews. As Hitler's supporters launched brutal attacks against Germany's Jews, their property, and their houses of worship, Lichtenberg announced before his congregation: “... outside the synagogue is burning, and that is also a house of God." Three years later, Berlin's Catholic clerics tried, without success, to obtain permission from the Gestapo to absolve Jewish-descended Catholics from wearing the Star of David during mass. Practicing Catholics, including Kurt Gerstein, a member of the SS, and Dr. Joseph Müller, an officer in Germany's military intelligence, kept the German Catholic leadership well informed of the mechanics of the extermination centers

\footnotetext{
56 Anonymous, The Persecution of the Catholic Church in the Third Reich. Facts and Documents Translated from the German (Gretna: Pelican Publishing Company, 1923), 525.

57 Michael Phayer, The Catholic Church and the Holocaust, 1930-1945 (Bloomington and Indianapolis: Indiana University Press, 2000), 15.
} 
in German-occupied Poland. On November 11, 1942, Cardinal Bertram denounced compulsory legislation mandating the annulment of marriages between Jews and Christians, emphasizing that the Christian duty to act humanely must also apply towards members of other races. Later in the month, Bertram sent an appeal to the Minister of Interior, "in view of the reputation of the German name at home and abroad," and in consideration of Christian moral law, calling for an end to the evacuation of "non-Aryans" from Germany. Bertram likewise insisted on the right of the Church to provide pastoral care to Catholics (many of whom the regime considered racially Jewish) imprisoned in concentration camps. ${ }^{58}$

Throughout the war, Provost Lichtenberg continued to say a daily prayer for Jews. Working alongside Lichtenberg, Margarete Sommer arranged for the emigration of "non-Aryan" Catholics out of Germany, and organized deliveries to inmates of Germany's concentration camps. Arrested on October 23, 1941, Lichtenberg argued before his interrogators that deporting Jews flatly contradicted Christian moral law and asked to accompany the deportees as their spiritual advisor. After spending two years in prison, Lichtenberg died on November 5, 1943 in transit to Dachau. Sommer survived the Third Reich and lived

58 Krieg, 1. 
until 1965. Yad Vashem honored her posthumously as one of the "Righteous among Nations," in 2003.59 Both Lichtenberg and Sommer operated under the approval of Berlin Bishop Graf von Preysing, arguably the most implacable opponent of Nazism in the entire German Catholic hierarchy. In March 1944, with the machinery of annihilation in Poland operating at its peak capacity, yet another high cleric, Cologne Archbishop Joseph Frings, declared that the persecution of Europe's Jews constituted "an injustice that cried out to heaven."60

The most pronounced acts of Catholic resistance to the National Socialist regime did not deal with its treatment of Jews. These examples of resistance are no less impressive, however, even if they complicate the legacy of German Catholicism in the context of the Holocaust, as considered below. In 1934, Bishop Gröber of Freiburg warned his flock against "heathen" ideas - a veiled but unmistakable reference to National Socialism. In 1935, Germany's bishops issued a pastoral letter criticizing the National Socialist regime's suppression of the Catholic press, its harassment of church meetings and its imprisonment of Catholic clergy. On April 10, 1938, Bishop Sproll refused to participate in the national referendum affirming Hitler's

59 "Gedenkstätte Yad Vashem zeichnet Berlinerin," Berliner Morgenpost (29 July 2003) http://www.morgenpost.de/content/2003/07/29/berlin/619572.html?redirID (accessed 06/19/2007)

${ }^{50} \mathrm{Krieg}, 1$. 
annexation of Austria. ${ }^{61}$ Throughout the twelve year history of the Third Reich, Cardinal Faulhaber was known for his efforts to resist the regime's attempts to secularize Germany's Catholic schools and confiscate church property. ${ }^{62}$

Robert A. Krieg believes that Germany Catholic lay worshipers registered their opposition to the regime by reviving popular Catholic popular religious rituals. These included the Feast of Corpus Christi and a spectacular pilgrimage to Aachen that attracted 800,000 followers in 1938. Further south, in rural Bavaria, Catholics repeatedly resisted efforts by local Nazi officials to remove crucifixes from public schools. In one well-reported case in 1941, a mob of 500 Bavarians in a small town overran the mayor's office and retrieved crucifixes that had been removed previously from the local school. ${ }^{63}$

Perhaps most impressively, in 1941, with World War II well underway, August Clemens von Galen, Bishop of Münster, delivered a riveting sermon before his congregation denouncing the regime's euthanasia program to exterminate Germany's disabled. The otherwise usually critical Gordon Zahn has lauded Galen's sermon as the "single

\footnotetext{
${ }^{61} \mathrm{Krieg}, 154-55$.

62 Gordon C. Zahn, German Catholics and Hitler's Wars (New York: E.P. Dutton \& Co., Inc., 1969), 101.

${ }^{63}$ Lewy, 315.
} 
most stirring statement of Episcopal opposition to Nazi rule."64 Bishops Franz Rudolf Bornewasser, Godehard Machens and Preysing joined Galen in condemnation. Germany's remaining Catholic press organs printed Galen's sermon. Many priests throughout the country read the sermon to their congregations. Remarkably, the regime opted to leave Galen unpunished. Goebbels warned Hitler that

... if anything were done against the bishop, the population of Münster could be regarded as lost to the war effort, and the same could confidently be said of the whole of Westphalia. 65

In November 1941, Preysing and Galen presented to Germany's bishops a draft letter that denounced the Reich's abuse of human rights, including the deportation of German Jews. Cardinal Bertram successfully argued against the letter's publication, however, worrying that it would bring harm to the Church. ${ }^{66}$

\section{Catholic Repression in the Third Reich}

Within months of assuming power, Hitler and his regime barred German teachers and civil servants from belonging to Catholic confessional organizations. The German Civil Service Law of April 7 threatened to dismiss thousands of Catholic civil servants who had been affiliated with the Catholic Center Party, the Bavarian People's

\footnotetext{
64 Zahn, 84.

65 Steigmann-Gall, 249.

${ }^{66}$ Krieg, 157.
} 
party and other Catholic organizations. As part of its efforts to achieve "coordination" between German society and the National Socialist state, Hitler banned simultaneous membership in Catholic youth and labor organizations and their National Socialist counterparts. He simultaneously made membership in the National Socialist organizations mandatory. On January 1, 1934, the Catholic Church in Germany had 435 periodicals at its disposal. By 1943, as a result of Hitler's efforts to end the independent press in Germany, this number had been reduced to seven. ${ }^{67}$

Prominent Catholics were among the earliest victims of Hitler's repressive apparatus. Against the Catholic Church and its organizations, in the words of Guenter Lewy, the National Socialist regime utilized "defamation, intimidation, economic reprisal and outright force." Hitler's "blood" purge against the leadership of the SA and Ernst Roehm on the Night of the Long Knives on June 30, 1934 is typically remembered as Hitler's attempt to squelch potential resistance to his rule within the Nazi party itself. With the brutal connivance of the SS and the German Army, Hitler in fact targeted much broader segments of the German population, including Catholics. Prominent Catholics claimed in these violent events included Dr. Erich Klausener,

${ }^{67}$ Lewy, 46, 117, 121, 148, 156. 
head of Germany's Catholic Action in Berlin, Adalbert Probst, leader of the Catholic sports organization, Dr. Fritz Beck, a Catholic student leader, and Gerlach. Against Catholic law, the authorities cremated their bodies and notified their relatives that they had committed suicide. 68

In 1935, in spite of his promises not to attack the Catholic church, Hitler's regime initiated a series of trials against the members of Germany's Catholic religious orders, charging that, among other things, they had violated the nation's currency laws and had engaged in sexual perversity and moral vice. Hitler halted the trials during the Berlin Olympics of 1936, only to resume them in the aftermath of Mit brennender Sorge in early 1937 . On May 28,1937 , four days after Karl Krieger, a forty-four year old Munich Catholic worker described by the Nazi press as a Catholic "youth leader," had been convicted for assaulting a minor, Goebbels declared in a national broadcast that ... a vast number of Catholic clerics have been tried for sexual crimes.... It is not a matter of regrettable individual lapses, but of a general corruption of morals such as the history of civilization has scarcely ever known.... In our civilized world, no other class of society has contrived to practice immorality and indulge in filth on a scale resembling that achieved by the German clergy in all its ranks.... We cannot possibly impose legal sanctions on unnatural vice and at the same time allow thousands upon

${ }^{68}$ Catholic law considers suicide to be a sin. Lewy, 124, 132, 169. 
thousands of priests and brothers of religious Orders to escape scot-free. ${ }^{69}$

Hitler's persecution of Catholics continued through World War II. In 1943, the regime executed Father Joseph Metzger for opposing Hitler's wartime policies. ${ }^{70}$ Dachau held 326 German Catholic priests when Americans liberated it on April 26, 1945. During the twelve years of the Third Reich, 74 of their colleagues had been executed. ${ }^{71}$

Prior to coming to power, Hitler claimed that Bismarck's Kulturkampf against Germany's Catholic institutions had been a mistake. He promised to pursue no such action once in power. By way of reminder, when Bismarck launched the war of civilizations against Germany's Catholic Church, he was not necessarily hostile towards Catholicism as a religion, per se. He did wish to terminate the intrusion of Catholicism in German politics, to minimize the influence of the ultramontane hierarchy on lay worshipers, and to sever the connection between Germany's Catholics and Rome. Some five decades later, in

69 The Persecution of the Catholic Church in the Third Reich... 305. The anonymous editor of this publication admits that some of the accusations against Church members were based on real incidents of sexual assault (some of the trials dated back to the Weimar years), but notes that Hitler and his supporters wildly exaggerated the numbers and often confused the essential facts. For instance, Krieger was not a priest and in fact, not the leader of any Catholic youth league recognized by Germany's ecclesiastical authorities. Provocatively, the author compares the trials to the Moscow Show Trials against Old Bolsheviks, which were in fact taking place at around the same time. See also Lewy, 156-158

70 Zahn, 134.

${ }^{71}$ Lewy, xxi 309. 
his first years of power, Hitler managed to accomplish much (but not all) of this, deploying methods of brutality and duplicity scarcely imaginable to the Iron Chancellor.

\section{Catholic Complicity and the Holocaust}

Nonetheless, most historical commentators are in substantial agreement that the Catholic Church in Germany did not do nearly enough to resist Hitler, oppose his wars or save Europe's Jews during the Holocaust. As Konrad Adenauer, himself a Catholic public figure during the 1920s (and a KV fraternity alumnus), wrote in 1946:

I believe that if all the bishops had together made public statements from the pulpit on a particular day, they could have prevented a great deal. That did not happen and there is no excuse for it. ${ }^{72}$

Through the twelve years of Hitler's rule, writes Guenter Lewy, the

Church remained primarily concerned with the preservation of its own institutions. In order to secure this end, the Church instructed its followers to obey their authorities. Otherwise, the Church made no public collective statements against the early boycott of Jewish businesses, against the sterilization laws, against the Nuremburg Laws, or against Kristallnacht. As Gordon Zahn wrote, Germany's Catholic authorities made no public statement against Hitler's wars, even if West German President Heinrich Lübke (a member of the CV fraternity

\footnotetext{
${ }^{72}$ Lewy, introduction xxv.
} 
during the 1920s) was to declare in 1960 that "No one who was not completely blinded or wholly naive could be completely free of the pressing awareness that this was not a just war."73

Although well aware of Hitler's extermination of Europe's Jews starting in the last years of the war, the Church collectively as an institution did very little. Kevin Spicer writes that individual Church leaders did work on behalf of Jews, but on the balance, "the Catholic Church failed to forge a theology of rescue and fellowship that embraces all people, especially Jews." Because their institutions had not been forced underground, Spicer reasons, Church leaders sought to challenge Hitler and his regime only in areas that conflicted specifically with Church teachings (like the wartime euthanasia program) or interfered with the exercise of its sacred duties, which included administering the sacraments, caring for the sick, and educating the next generation of faithful. Otherwise, the Church authorities typically, although not always held to the view that "Catholics took care of Catholics, Protestants took care of Protestants and Jews took care of Jews."74

At times, the Church's cooperation with National Socialism went beyond passive complicity. On March 28, 1933, just five days after the

\footnotetext{
73 Zahn, 181.

${ }^{74}$ Spicer, 4, 6, 121.
} 
Enabling Act suspended the Weimar constitution and confirmed Hitler as dictator, Germany's bishops bewildered many of their followers by lifting their ban against membership in the National Socialist party. Through the spring and summer of 1933, Germany's bishops worked with the Reich government and with their superiors in Rome to consummate a Concordat between the Vatican and Berlin. Through the negotiations, Germany's Catholic authorities, including former Center Party chair Ludwig Kaas and Vice Chancellor von Papen, ${ }^{75}$ assented to, and even encouraged the dissolution of the Catholic Center Party and the Bavarian People's Party (BVP). They said little when Hitler's followers disrupted a meeting of the Catholic Kolping Society in Munich, vandalized Catholic newspapers, charitable organizations and social clubs, and imprisoned almost 2,000 members of the BVP while negotiations were still underway. ${ }^{76}$ In part, both the Vatican and Germany's Catholic hierarchy hoped that the Concordat would serve as a contractual lever to secure the rights of the Church and preserve its dense organization network, lauded by Center Party historian Karl Bachem as recently as 1931 as the most resilient in the world. From

\footnotetext{
75 Kaas had recently relocated to Rome, permanently, as it turned out. A Catholic aristocrat, Papen had been expelled from the Center Party for his role in having Brüning removed from power in 1932. With Hindenburg's approval, but without the consent of the Center Party, Papen then formed his own minority government. ${ }^{76} \mathrm{Krieg}, 7$.
} 
the preceding discussion, it should be clear that the Concordat largely failed in securing these ends. Cardinal Faulhaber declared in a sermon in 1937, however, that the Concordat did offer an affirmation of “...immeasurable significance for the reputation" of Hitler's government abroad. ${ }^{77}$ After the war, these words would come back to haunt the Church.

Through the twelve-year history of the Third Reich, the Church continued to admonish Catholic Germans to obey their authorities. As is explained in Chapter 3, Church authorities could call on a long tradition of Catholic theology running through St. Augustine and St. Thomas to support their admonition for civic cooperation. As Lewy concludes, Catholics who "fought actively against the Hitler regime were rebels not only against the state, but against their ecclesiastical authorities as well."78

In explaining why Germany's Catholics remained largely silent when confronted with a criminal regime, historical interpretations diverge radically. On one side, Lewy, Zahn, Amery, Lukens and most forcefully, Daniel Jonah Goldhagen, all emphasize the points of ideological congruity between National Socialism and contemporary German Catholicism. They reject the idea that the Church's leaders 
turned a blind eye to Hitler's crimes merely because they were afraid of what Hitler might do to them or to Germany's Catholic population. In part, Germany's Catholic leaders affirmed many of the essential points of National Socialist ideology. Both Church and Hitler were hostile to democracy, to parliaments, to parties and to Weimar. Even if for very different reasons, both rejected Versailles and supported greater German revanchism. ${ }^{79}$ Both were hostile to Marxism and Bolshevism. Some German Catholics believed that, in National Socialism, they had found an ally against capitalism that would reorganize the German economy along cooperative and corporative lines. (See Chapter 5.) Both emphasized the needs of the community over individual "greed," a paradigm which Catholics in particular felt that modern society had inverted. Broadly, if vaguely, both opposed the perceived permissiveness and degenerate morality that had supposedly become the signature of Weimar culture. One Catholic official reportedly believed that National Socialism would offer the power to attack the "cesspool" of drugs, crime, prostitution and perverse sexuality that was supposedly synonymous with the capital of Berlin. 80

\footnotetext{
79 See Chapter 6. Germany's clerics were persistently aware that Catholics had been disproportionately affected by Versailles, being alienated from their presumably rightful home in Alsace-Lorraine, Poland, the Czech Sudetenland and Austria. It can almost certainly be said that Hitler likewise wanted to reclaim these regions, but not to add more practicing Catholics to the Reich's population.

${ }^{80}$ Lukens, 162.
} 
Most ominously, as Goldhagen insists, both Church and Hitler were fundamentally anti-Semitic. By way of association with the Vatican, concludes Goldhagen, and for indigenous reasons of its own, Germany's Catholic Church must be implicated in the centuries' long pattern and practice of Christian persecution of Jews. The extermination of Jews in Roman Alexandria in 414 AD inaugurated this pattern and practice. One of its more dramatic moments took place when Christian Germans forcibly evicted thousands of Jews from the Rhineland in the Middle Ages. ${ }^{81}$ Goldhagen writes that Germany's Catholic Church under the Third Reich abandoned the Jews "to their countrymen's ever intensifying eliminationist persecution" in no small part because Church leaders agreed with the essential justification behind it. To ask why Germany's Catholics did not do more to stop Hitler's deportation and extermination of Europe's Jews, in Goldhagen's opinion, misstates the question. Why would they, when they shared the regime's fundamentally eliminationist values?

To sustain his argument, Goldhagen not unreasonably calls on a number of contemporary German Catholic documents, including the Handbook on Contemporary Religious Questions, which categorized Jews

\footnotetext{
81 In the centuries to follow, these Jews would form the core of the vibrant Yiddish speaking Jewish culture in Poland and the western reaches of the Russian Empire. These Ashkenazi Jews were numerically the primary victims of the Holocaust.
} 
synonymously with Bolshevik terrorists. Archbishop Conrad Gröber, reminds Goldhagen, a supposed opponent of National Socialism, in March of 1941 published a pastoral letter blaming Jews for the death of Christ. In this letter, Gröber called on the Gospel of Matthew to remind his flock of the "self-imposed curse," that would be on the heads of Christ's murderers, as well as their children. This curse or, more accurately, prophesy, Gröber wrote, “... has come terribly true, until the present time, until today." 82

When the Catholic Church stood up to Hitler on other matters, such as the euthanasia program or the removal of crucifixes from Bavarian schools, the consequences were in fact minimal. In light of its success in other matters, reasons Goldhagen, the Church's refusal to stand up for Germany's Jews is all the more inexplicable. Following Doris Bergen, Goldhagen observes that Germany's Catholic military chaplains witnessed countless atrocities on the eastern front and elsewhere, but said and did little, if anything. Goldhagen also argues that Germany's Catholic clerics complied willingly when Hitler's officials demanded access to Church genealogical records in order to identify Jews and enforce the Nuremberg Laws. ${ }^{83}$ The simple fact of the matter

82 Daniel Goldhagen, A Moral Reckoning: The Role of the Catholic Church in the Holocaust and its Unfulfilled Duty of Repair (New York: Alfred E. Knopf, 2002), 85-86. ${ }^{83}$ Until the late 1800 s, only the churches recorded births in Germany. 
is, according to Goldhagen, Germany's Catholics did not oppose Hitler on the question of Jews because ideologically they found no reason why they should. Following Guenter Lewy, Goldhagen concludes that, had Germany's bishops altered their position and spoken up collectively on behalf of Jews, "their own followers would probably have failed to understand and approve..." 84 As Goldhagen writes more broadly:

Antisemitism led to the Holocaust. Antisemitism has been integral to the Catholic Church. The question of what the relationship is between the Church's anti-Semitism and the Holocaust should be at the center of any general treatment of each. 85

Not all are willing to tie the ideological knot between Church and Hitler so tightly. Spicer, Krieg and Phayer continue to emphasize the fundamental dissimilarities between National Socialist ideology and contemporary German Catholicism. Spicer writes that German Catholics were simply unprepared institutionally to understand and recognize "the inherent evil of National Socialism and the devastation it would bring to Germany and the world." Otherwise, Germany's Catholic leaders were taught in their seminaries to follow the advice of

${ }^{84}$ Goldhagen, 59, 61, 63, 86, 107 - Lewy quote taken from the 1964 edition, 294. 85 In so doing, Goldhagen continues to maintain his position that inaugurated one of the most spirited, if acrimonious debates in the Holocaust literature; contradicting Christopher Browning, Goldhagen continues to maintain that, above all else, centuries-long historically ingrained hatred towards Jews explains why Germans and their allies systematically murdered millions of Jews in the last years of the war. Goldhagen, 39, 59. 
St. Augustine and St. Thomas to avoid direct conflicts with the state. ${ }^{86}$ Krieg adds that contemporary Catholic ecclesiology understood the Church to be a societas perfecta, a "perfect society," completely outside and above the state. Under this belief, Germany's clerics usually opted for secret negotiations with the National Socialist regime when their interests were endangered, but otherwise acted to preserve the Church's institutional integrity. This strategy had its benefits. In particular, the Church survived the Third Reich. For that reason, it was well situated to play a role in the post-World War II reconstruction of Germany. As historian Klaus Schatz writes, 1945 was hardly a "Stunde Null" or Zero Hour for the Catholic Church. But, during the long terror of Hitler's rule, the Catholic Church was not able to fulfill the basic precept of Christian law to love one's neighbor. As Krieg concludes, it was not until the Second Vatican Council of 1965 that the Catholic Church recognized that it had a responsibility to ensure social justice in the world beyond its institutional boundaries. ${ }^{87}$

\section{The Catholic Fraternities and National Socialism}

In the shorter term, the Catholic fraternities stood against the rising tide of nationalism that overwhelmed German universities in the last years of the Weimar Republic. As explained in Chapters 3 and 6,

\footnotetext{
86 Spicer, 14.

87 Krieg, 171.
} 
when the umbrella organization of the German students, the German

Student Body (DSt), turned ever more firmly towards extreme

nationalism, the Catholic KV and Unitas fraternities turned away. Both

the KV and Unitas fraternities withdrew from the DSt following its

annual convention in 1930. In so doing, their leaders announced that:

As long as the German Student Body is not able to achieve a loyal relationship with the present state and its symbols, and as long as the inner contradiction between the Aryan principle in Austria and the principle of civic citizenship in the Reich is not resolved ${ }^{88}$ the KV and UV are unable to stand in its support. ${ }^{89}$

When the CV insisted on remaining in the organization, in part because its leadership believed that continued participation was required to counteract the rising influence of National Socialism, a press war of sorts erupted in the Catholic Kölnische Volkszeitung and at least two fraternity newspapers. Specifically, supporters of the KV and Unitas charged that the CV had betrayed Germany's Catholics by failing to

\footnotetext{
${ }^{88}$ As explained in Chapters 3 and 6, many national fraternity organizations accepted Austrian chapters that implemented the so-called "Aryan principle" in their constitutions. These provisions effectively banned Jews, even when they were otherwise culturally and linguistically German and were citizens of Austria or Germany. The inclusion of these Austrian chapters in Germany's national fraternity organizations violated Prussian state law.

89 Peter Stitz, Der CV 1919-1938. Der hochschulpolitische Weg des Cartellverbandes der Katholischen deutschen Studentenverbindung (CV) vom Ende des 1. Weltkrieges bis zur Vernichtung durch den Nationalsozialismus (Munich: Herausgegeben von der Gesellschaft für Studentengeschichte und studentisches Brauchtum e.V., 1970), 81.
} 
maintain a united front against the right and in support of the Weimar Republic. 90

Be that as it may, the CV had no shortage of individuals willing to criticize the National Socialists. At the fraternity's sixtieth annual convention in Koblenz in July 1930, Erhard Schlund warned that the National Socialists threatened to place state, Volk and blood over God and church. At the same convention, fraternity leader Herrmann Hagen recommended that the fraternity consider disciplinary action against members appearing on National Socialist party lists. 91 Six months later, again writing for Academia, Schlund took credit for opposing National Socialism since as far back as the failed Hitler putsch against the Bavarian government in 1923. In the aftermath of this event, Schlund condemned Hitler in the Munich Allgemeneischer Rundschau. Schlund likewise authored a detailed criticism of the National Socialist position on religion, "New Germanic Heathenism in Contemporary Germany,"92 which he reckoned had sold 30,000 copies since its initial publication in 1924. Offering a detailed critique of National Socialism in the February 15, 1931 edition of Academia, Schlund argued that, among other things:

\footnotetext{
90 Stitz, 83.

91 Stitz, 83.

92 Neugermanisches Heidentum in heutigen Deutschland
} 
1. National Socialism was a false doctrine and incompatible with the tenets of the Church.

2. People who voted for the NSDAP during the last election (when its support in the German electorate skyrocketed) could not have been aware of the threat that Hitler's party posed to religion and the Church.

3. The National Socialist party must be judged as having the same shortcomings as liberalism and socialism.

4. The CV, as a self-consciously Catholic organization, must remain true to Catholic doctrine and the decisions of the Church.

5. Membership in both the National Socialist party and the CV was incompatible.

6. The CV would not tolerate within its ranks official party representatives, National Socialist writers or publications, public agents of the party, the wearing of National Socialist uniforms or other insignia.

Those who failed to see the contradiction between National Socialism and Christianity, insisted Schlund, must be enlightened and led to the right path. ${ }^{93}$

On April 15, 1932, the CV alumni announced in Academia that the "question of membership" in the NSDAP had been decided by our "highly respected bishops." They went on to write that

For our fatherland and for the entire German people we place at disposal all of our powers as a self-evident civic duty. And we can not and will not tolerate members of our

93 Stitz, 97. 
organization also being members of the NSDAP. This has nothing to do with party politics. ${ }^{94}$

The alumni of the CV tried to emphasize that the current activities of either major Catholic political party did not influence their decision to oppose the NSDAP. Approximately five months later, the national CV organization likewise affirmed the bishops' prohibition against Catholic membership in the NSDAP. The organization's leadership recognized that the fraternity "did not have the power" to enforce the prohibition on individual CV membership in the NSDAP. Nonetheless, "within its ranks," the CV would not tolerate "National Socialist propaganda, or representatives of the party." Its leaders continued: "We will not tolerate uniformed members or members wearing party insignia at fraternity functions." 95

Starting in 1930, the KV fraternity likewise announced that it would honor the hierarchy's warnings against National Socialism. In the previous decade, attempts by some KV members to form a splinter National Socialist group had evidently gone nowhere. At least one prominent KV alumnus, Martin Spahn, had earned a reputation as a

\footnotetext{
94 "CV and Nationalsozialismus," Academia 44, Nr. 12 (April 15, 1932): 333. 95 "Die Beschlüsse der 61. CV-Versammlung," zusammengestelt von Dr. Hermann Hagen Th, München, Academia 45, Nr. 6 (September 15, 1932): 137-138.
} 
prominent Catholic supporter of right-wing causes. ${ }^{96}$ But, in spite of Spahn's influence, only a handful of KV members could be found in the National Socialist student unions. ${ }^{97}$ In October 1930, an unnamed contributor to the fraternity's publication quoted a statement from the Bavarian bishops' conference. Specifically, he argued that "National Socialism offers a cultural and political program of errors, because it rejects the essential points of Catholic belief." The writer similarly approved of the stance taken by the various Catholic youth groups banning membership in the Hitler's party or its auxiliary organizations. "At thousands of assemblies and announcements," the writer declared proudly, "German Catholics have united against National Socialism, have closed ranks in the struggle against the Hitler movement." $\mathrm{He}$ insisted that particularly young Catholics were "determined" to carry the struggle against the NSDAP "to the end." KV had banned simultaneous membership in the NSDAP. ${ }^{99}$

Among the three national Catholic fraternal organizations, Unitas early on stood most consistently and firmly against Hitler, and more broadly, against the intrusion of racism and extreme nationalism in

96 Ironically, and perhaps appropriately, it fell on Spahn to dissolve the national KV organization in 1935.

97 Friedhelm Golücke, Korporationen und Nationalsozialismus (Schernfeld: SH-Verlag, 1990), 14.

98 "Die katholische Jugend gegen den National-Sozialismus," Akadem. Monatsblätter 43, \#1 (October 1930): 388-389.

${ }^{99}$ Golücke, 14. 
German student politics. Unlike the CV and $\mathrm{KV}$, Unitas from the very beginning rejected any collaboration with the DHR or its local affiliates. Early in the history of Weimar, Unitas leaders were also more assertive in expressing their support for Germany's new republic. 100 In 1928, Carl Mailer, a student of philosophy with the Unitas-Guelfia chapter, delivered a lecture lamenting the assassination of German foreign minister Walther Rathenau some five years prior. Rathenau had been a leading figure in German industry before the war. During the war, Rathenau organized Germany's wartime production, which otherwise would have been crippled by the British blockade. After the war, Rathenau served Germany ably, first as its reconstruction minister, and later, as its foreign minister. Nonetheless, the extreme right, including the National Socialists, vilified Rathenau, if for no other reason, because he was Jewish. On the morning of June 24, 1922, two army officers assassinated Rathenau as he rode in his car in Berlin in broad daylight. Germany's sympathetic judicial officials, themselves never convincingly invested in the republic that paid their salaries, handed down remarkably lenient punishments. In his address to a Unitas function, Mailer admitted that "to be sure, many criticized the work, position and

100 See Chapters 3 and 4. 
race of this man in dark repulsion." But for Mailer, Rathenau's death represented the highest "sacrifice" and "martyrdom."101

Even members of the Ring, at the time seen as the most nationalist of Germany's Catholic fraternal organizations, criticized Hitler, his movement, and his ideology. In the March 1930 edition of its publication, Josef Bussmann, a political economist, recognized that Germany's student body stood in a state of crisis, confronted by radicalism and fanaticism on all sides. He lamented that Germany's young Catholics were unable to form a united front at precisely the time when the danger to Catholicism was as great as ever. Bussmann nonetheless believed that Germany's Catholic youth had the power to form a "disciplined storm troop of young men," to launch a "holy war for truth, reason, for openness and honesty." Bussmann concluded that Germany's young Catholics must unite against the "errors of our time." These included: Bolshevism, Marxism, Liberalism and National Socialism. ${ }^{102}$

101 Aus einem Festvortrag, gehalten auf einer Morgensitzung des U.V. München, von stud. phil. Carl Mailer (Unitas-Guelfia), "Die Weltanschauung Rathenaus," Unitas 68, Nr. 11/12 (August 1928): 173-174.

102 Diplomvolkswirt Josef Bussmann (Nibelungiae), "Aufgaben und Aufmarsch der katholischen deutschen Jugend," Der Ring 7, 1/3 (March 1930): 4-7. 


\section{Experiencing Nazism}

On September 12, 1931, the CV's publication reported a disturbance on Berlin's Kürfurstendamm, ${ }^{103}$ during which unidentified National Socialists attacked bystanders on the occasion of the Jewish New Year. As the publication explained, these attacks were planned and organized. The perpetrators shouted Juda verecke, Deutschland erwache ("Jews to the ground, Germany awake") and launched fist and knife attacks against "blameless pedestrians whose only crime was that the National Socialists decided that they looked like Jews." In what must have been a visually horrifying scene, many of the victims were left unconscious, in blood, on the pavement. "The majority of the victims," claimed the writer, were not Jewish. Their number included a well-known Berlin attorney and CV alumnus, Peter Derichsweiler. Ironically, this was the same Derichsweiler who in the previous July had spoken on behalf of the German youth at the Albert Leo Schlageter national memorial services in Düsseldorf. ${ }^{104}$ The attack came close to

\footnotetext{
$103 \mathrm{~A}$ wide avenue that houses much of western Berlin's upscale retail stores. The "Ku-Damm" is also a popular pedestrian destination on most evenings.

104 See Chapter 2. P. Derichsweiler, Mitglied des Arbeitsauschusses im Ausschuß für die Errichtung eines Schlageter-National-Denkmals, "Das Schlageter-Ehrenmal in Düsseldorf kommt," Academia 42 (15 November 1929): 222-224. Von Dr. Türk, "Die Einweihung des Schlageter-Nationaldenkmals in Düsseldorf am 23. Mai," Academia 44, Nr. 3 (July 15, 1931): 68-71. He should not be confused with Albert Derichsweiler, former CV member, National Socialist squad leader from 1933-1934, Circle Führer for the western German region from 1934 to 1936 and thereafter, a Führer of the entire NSDStB.
} 
claiming Derichsweiler's life. He was left unable to work and in need of ongoing medical care. Presciently, the article concluded that: "Even if the National Socialist party itself denies responsibility for these acts, it is nonetheless not to be misjudged that this was done in its spirit."105

National Socialist attacks against the Catholic fraternities were not always so random or unintentional. As explained in Chapter 3, right-wing hostility to Catholicism registered itself as early as Hitler's Putsch against the Bavarian government in 1923, during which proHitler agitators claimed that the Bavarian government was in the hands of "Jesuit hirelings," and denounced Munich Archbishop Cardinal Faulhaber. At that time, the local affiliate of the German University Ring (DHR) refused to apologize, 106 thereby provoking an exodus of Catholic fraternity supporters from the organization. By 1930, the DHR and its affiliated organizations were thoroughly saturated with Hitler supporters, who also now had an organization of their own. During the early 1930s, National Socialist students launched attacks against Catholic fraternity members in Austria. 107 On November 16, 1932, in

105 "Ein CVer von Nationalsozialisten niedergeschlagen," Academia 44 (October 15, 1931): 167.

106 The national office of the DHR in Berlin did insist that Kleo Pleyer, the most wellknown student supporter of the Putsch, resign his position as its newspaper's editor. 107 By way of reminder, through the Weimar Republic, Austria was part of Germany's university landscape. For all intents and purposes, German students did not treat Austria as a separate country. Austrian student associations were admitted to their corresponding German national umbrella organizations. German university events 
the city of Graz, members of the dueling fraternities and the local SA attacked an event sponsored by the German Catholic school union Südmark, and engaged in street battles against CV and KV supporters. (Reportedly, some members of the local Catholic Ring fraternity sided with the National Socialists.) On December 2, the violence spread to Vienna. ${ }^{108}$

\section{Explaining the Appeal of Nazism}

Not all Catholic fraternity criticisms of National Socialism could be reduced to formal affirmations of Episcopal pronouncements, or to reflexive reactions in the face of Nazi violence. Through the early 1930s, when they began to devote more attention to Hitler and his movement, Catholic fraternity writers offered surprisingly sophisticated, original and insightful analyses of National Socialism. Commentators in the Catholic fraternity periodicals were especially adept at explaining why Hitler's movement enjoyed popularity among younger Germans. In the fall of 1930 , Dr. Berning, an alumnus of the Unitas fraternity, concluded that the broader turn towards Hitler among Germany's student body represented a reaction not only against Weimar, but also against the values of the generation (including his) that had come of age

were frequently hosted on Austrian soil. This was also the case with the Catholic fraternities.

108 Stitz, 106. 
before World War I. Berning's article generated enough interest to appear both in the Unitas journal, as well as the journal of the Catholic $\mathrm{KV}$. Berning began his discussion by recognizing that the "yearning for community, for meaningful membership" had become powerful among Germany's students. Germany's students, he averred, were no longer impressed with autonomy; "they want to be led." On the one hand, Berning suggested that the willingness of Germany's young to submit to authority and discipline might be seen as a positive development. For instance, unlike their predecessors, Germany's university students were willing to support the national cause by affirming the value of hard labor and dismissing "empty intellectual speculation." 109

However, Berning warned that Germany's students were not always able to discern the difference in the varieties of conservatism that had emerged from the splintering of the right in German politics during the preceding decade. ${ }^{110}$ Berning located essentially three distinct strands within Germany's conservative movement. First, he described the "original" conservative thinkers of the nineteenth century. These thinkers in their writings and other pronouncements had

109 Dr. Berning (A.H. Unitas-Marburg), "Die Konservative Wendung in der Jugend und die rechtradikale Gefahr," Unitas 70, Nr. 11/12 (August-September, 1930): 181. This article also appeared in its entirety in the Akadem. Monatsblätter 43, \#1 (October 1930): 93-99.

110 Berning, "Die Konservative Wendung in der Jugend...," 93-99. 
emphasized the community as organic, vital and biologic. These thinkers similarly understood the individual as firmly embedded within the community, as essentially unthinkable without it. Traditional conservatives did not see individual freedom as absolute. Instead, they argued that freedom was best protected by submitting to the authority of the community. The original conservative thinkers understood time to be a continuous stream, which should not be disrupted by progressive thought or revolutionary action. ${ }^{111}$

So far, traditional conservatives had much in common with prevailing Catholic theology. The two diverged, according to Berning, only in their profoundly differing conceptions of the state. While conservatives, like socialists and liberals, understood the state to be the supreme authority, Catholic thinkers continued to embed the state into a much larger superstructure that included Church, family and local community, all with distinct juridical roles to play in ordering the life of the individual. Catholics must reject the traditionally conservative idea, insisted Berning, that the Altar should play a merely auxiliary role in support of the state. ${ }^{112}$ As Chapter 5 should make clear, following a long line of papal pronouncements, Catholics in the early twentieth century continued to insist that the Church should be understood as

${ }^{111}$ Berning, "Die Konservative Wendung in der Jugend...," 183.

112 Berning, "Die Konservative Wendung in der Jugend...," 183. 
distinct, independent, legally equal, and morally superior to temporal authority.

Contemporary conservatism in Germany, continued Berning, could be divided into a nationalist and a national revolutionary direction. While a "true conservative" would reject revolution, Berning admitted that Weimar had bred a new kind of conservative thinker who saw violence and subversion as a legitimate means to overthrow illegitimate authority. Berning suggested that both strands, the "true" and the "revolutionary" conservative direction, could be found in the German National People's Party (DNVP), embodied respectively in party veteran Graf Westarp, and a relative upstart in conservative German politics, publishing magnate Alfred Hugenberg. ${ }^{113}$

Neither of these strands of conservative thought, warned Berning, should be confused with National Socialism, which developed "sociologically in very different classes." Unlike conservatism, argued Berning, National Socialism is antibourgeois, and deliberately, not incidentally, revolutionary. In seeking to overthrow the existing Weimar state, National Socialism did not intend to restore a past state of affairs. To support this claim, he quoted Graf Reventlow's 1931 publication "Reichswert," which insisted that National Socialism wanted

\footnotetext{
${ }^{113}$ Berning, "Die Konservative Wendung in der Jugend...," 183.
} 
"fundamental, ground shaking revolutionary upheaval." In his publication "The Second Revolution," (1926) Joseph Goebbels likewise affirmed that his movement needed to have the courage to destroy everything that is held as holy and as tradition, in education, friendship and human love. ${ }^{114}$

Among the right-wing movements on Germany's landscape, National Socialism had to be seen as the most dangerous and the most destructive, both to Germany generally, and to the Catholic Church particularly. National Socialism, warned Berning, demanded an omnipotent Machtstaat to replace the traditional Rechstaat. ${ }^{115}$ It sought to pursue nakedly imperialist war aims and to eradicate individual personality in favor of a military dictatorship that would "blanket" both church and school in nationalism. It its conception of the supremely omnipotent and invasive state, National Socialism could not diverge any more radically from Catholicism. Quoting Hitler's Mein Kampf directly, Berning concluded that Hitler clearly favored German Protestantism over Catholicism, in that the former (unlike the latter) was perfectly at ease in a subordinate role to the state. ${ }^{116}$

\footnotetext{
114 Berning, "Die Konservative Wendung in der Jugend...," 183. 115 Very basically, authority in a Rechtstaat, regardless of the actual constitutional format, is structured and limited by laws. In a Machtstaat, by contrast, the authorities have the virtually unlimited power to do what must be done. 116 Berning, "Die Konservative Wendung in der Jugend...," 184.
} 
Among the conservative movements in Germany, National

Socialism alone had the power to appeal to Germany's youth on a mass

scale. Berning's insightful assessment of National Socialism on this

topic is worth quoting at length. Specifically, Berning worried about the ability of National Socialism to impress young Germans with its

... symbols, mysticism, and belief in leadership, with its strong, dictatorial, authoritarian entourage, with its intensively internal disciplinarian military and practical working methods. In contrast to the other conservative movements, National Socialism has a youthful élan, a sense of adventure and risk.

Young Catholics, Berning concluded, "have to ensure that they are not seduced by its hierarchical leadership and its pathos for order."117

Not all Catholic fraternity commentators were quite so patient or forgiving with Germany's students. Franz Weber, General Secretary of the Augustinian Association for the Maintenance of the Catholic Press and a leader of the press office of the Ring fraternity, angrily and dismissively denounced students who he believed were biting the hand that fed them. The Prussian government, ${ }^{118}$ reminded Weber, contributed 1,000 marks a year to the education of each student. In response, "many of its students shame this." How were students

117 Berning, "Die Konservative Wendung in der Jugend...," 184.

118 Under the Weimar constitution, jurisdiction over the university system remained in the hands of the constituent states. Prussia remained Germany's largest and most influential state, and at least until Hindenburg asserted central control using one of the more controversial provisions of the Weimar constitution, it typically remained in moderate socialist and democratic hands. 
thanking the state for its concern for their welfare? Did they leave the university as upstanding citizens, ready to assume their natural leadership roles in German society? "No!" railed a disgusted Weber. After three or four years, students who had yet to take a test119 "insult their teachers, their benefactors, the state, battle with the police and beat each other up." Sounding more like a commentator of the previous centuries, before nationalist minded university leaders sought to replace the feasting, drinking, dueling lifestyle with a more serious ethos, Weber concluded that German nation could not help but have a low opinion of students. ${ }^{120}$

Wherever the fault for student apathy and hostility actually lay, yet another commentator in 1932 continued to worry acutely that National Socialism might be able to seduce young Germans, even Catholics, with potentially disastrous consequences. In the June 1932 edition of Academia, August Nuss conceded that the National Socialists should be seen as the clear victors in the radicalization of Germany's students. (By contrast, student support for the Communists was practically nil.) Like Berning, Nuss wrote that Germany's students had

\footnotetext{
119 Written objective tests in the German university setting, particular in the liberal arts, are rare, and were rarer still before World War II, when students were typically held to account with oral examinations at the end of their studies.

120 Von Franz Weber, Generalsekretär des Augustinus-Verein zur Pflege der katholischen Presse, Leiter des Pressamtes des Ringes Katholischer Deutscher Burschenschaften, Der Ring 6, Nr. 8/9 (November 1930): 99-101.
} 
come of age under fundamentally different circumstances than had their generational predecessors. In part, Germany's students were hostile to other elements of the German population, including the proletariat and Jews, because they "had not lived a life of fulfillment," and because, in many instances, their "private and public lives had overlapped." By contrast, among the pre-World War I cohort, students had lived relatively quiet lives, in the private sphere, "without the worry of politics." Nostalgically, Nuss described the student years of his cohort as "a good time that opened the door to academic freedom." Throughout their studies, students in the old days could count on support from stipends and private funds. ${ }^{121}$

Then came "the terrible world war, revolution, inflation and the reparations crisis." Students with no knowledge of the pre-World War I years, averred Nuss, "cannot understand the world from our perspective." In their lives, politics could be nothing else than national politics. Germany's moderate parties, lamented Nuss, were everywhere on the decline. Weimar electoral statistics certainly bear him out. By 1932, the moderate German Democratic Party (DDP) and German People's Party (DVP) had all but disappeared, as German voters

\footnotetext{
121 Von August Nuß Hr, R-F, Ndm, Berlin, "Der politische Radikalismus auf den deutschen Hochschulen," Academia 45, Nr. 2 (June 15, 1932): 42. This article in part reacts to a talk made by student leader Otto Pieper, the written transcript of which appeared in the Deutsche Rundschau in February 1932.
} 
bifurcated to the left and to the right. Among the non-Socialist parties of the so-called Weimar coalition, only the two Catholic parties were holding on, if tenuously. The problem, continued Nuss, was not that the moderate parties offered bad programs. The problem was that they were not sufficiently "contemporary" or "imminent." It just would not do anymore, he warned, for a party to represent specific classes or interests. Germany's moderate parties had to learn to appeal to their young supporters more broadly. ${ }^{122}$

Their failure to do so, concluded Nuss, had left Germany's youth despondent and cynical, leading them instinctively to hate and distrust democratic and republican government. In the meantime, the party bureaucracies and the delegations serving in parliament had done nothing to get the citizens to recognize a higher sense of political responsibility. Their failings were evident among Germany's youth. Nuss explained: "The youth is simple. They love or they hate. They do not go through the trouble to find the silver lining or the core of good within the bad." Unlike their more patient (if resigned) elders, Germany's youth will not respect a constitution simply out of any rational republicanism or sense of duty without affection. Nuss hoped that Germany's youth, including young Catholics, would recognize that

\footnotetext{
122 Nuß, "Der politische Radikalismus auf den deutschen Hochschulen," 42.
} 
their first duty was to study, not provoke street brawls or disturb university functions, as was now increasingly the case. "State and youth, youth and state, belong to an inseparable community of fate," he suggested. In an obvious reference to National Socialism, Nuss concluded that "today, it is no longer the case that he who has the youth has the future, but he who has the future has the youth."123 Germany's youth, he worried, were already counting on and looking forward to a Nazi victory.

In October 1930, Alfons Steinrötter of the KV conceded that Germany had entered a state of political crisis. The Weimar Republic now faced danger from both the National Socialists and the Communists, either of which might make a Putsch against the national government. Steinrötter wrote that in the current "emergency situation" - namely, the effects of global depression and the paralysis of parliamentary government - Germany's bitter voters could not help but be pulled out of the middle into two extreme directions. "This struggle is not just about politics, but also about ideas and a worldview," explained Steinrötter. ${ }^{124}$

\footnotetext{
123 Nuß, "Der politische Radikalismus auf den deutschen Hochschulen," 42. 124 Alfons Steinrötter, Horst-Emscher, "Die politische Situation und Staatsphilosophie. Um die Einheit der neudeutschen Geistesentwicklung," Akadem. Monatsblätter 43, Nr. 1 (October 1930): 296-299.
} 
Steinrötter remained optimistic that Germany's current crisis might be redeemed through a Christian renewal, a "new economic and working order" in which social, economic and cultural interests would all be harmoniously incorporated into Germany's constitutional structure. ${ }^{125}$ Writing for the KV journal a year later, Dr. Tischleder agreed. Tischleder noted, however, that the forces of extremism assailing German politics at the moment could claim a long genealogy. Tischleder likened modern ideology to heresy. Since the European enlightenment in the late eighteenth century, various extremist ideals had worked against each other in dialectical fashion, each generated by a "form of protest, a no." "The heresy and radicalism of every type," he explained, is a "one sided negative protest or reaction." Liberalism, he instructed, represented a protest against absolutism, only to become a power of absolutism in its own right with its "counting arithmetic." Evidently, he associated liberalism with utilitarianism - the idea that the social welfare could be calculated by adding together the sum total of individual indices of happiness without any concern for the broader whole. ${ }^{126}$ In response, socialism originated as a protest of the "fourth

\footnotetext{
125 Steinrötter, “Die politische Situation und Staatsphilosophie..., 299.

126 Tischleder did not drop any names, but Adam Smith and Jeremy Bentham come to mind.
} 
estate" - presumably meaning the industrial proletariat - against the power of the "victorious bourgeoisie." 127

Both Communism and National Socialism, reasoned Tischleder, can be seen as another stage of this dialectical interplay. Tischleder followed along the line of Catholic thinking (see Chapter 5) that denounced both liberal capitalism and socialism as too narrowly focused on the material aspect of human happiness. In the longer term, Tischleder hoped that Germany would be able to move beyond the idea of the political community as merely the organization of "... atomized individuals, purely individual goals and purposes, as a product of individual wills." But, in the shorter term, still enveloped in a state of profound political crisis, Germans faced the most dangerous forms of radicalism of all. These were, on the one hand, the Marxistmaterialist, and on the other, in a clear reference to Hitler's movement, the "racial organic, with the state being the embodiment of Volk and race." Both of these could claim the heritage of "Hegelian state metaphysics." Both saw the state "as everything." And both, warned Tischleder, would reduce the individual to slavery. ${ }^{128}$

\footnotetext{
127 Prof. V. Tischleder, Münster, i.W., "Der katholische Staatsgedanke also Echo der ursprünglichen gefunden katholischen Wesenmitte," Akadem. Monatsblätter 44, \#1 (October 1931): 120-122.

128 Tischleder, "Der katholische Staatsgedanke...," 122.
} 
Tischleder believed that every form of "radicalism" was capable of seeing only one dimension of reality at a time. This is why, to reiterate his observations that opened this chapter, radicalisms work in "cheap black and white techniques." As negations, radicalisms rely on primitive claims that speak to uncomplicated realities. Their appeals are largely instinctive and emotive, that is, based on "Eros" and "pathos." They are not able to speak to a larger truth or to appeal to human reason. 129

Clarification here is in order. By the use of reason, Tischleder did not mean "challenging the teachings of Christianity," a legacy of the Age of Enlightenment that produced a "series of ideological errors that we still are molested with and that only the firm social teachings of the Church can combat effectively." This is the definition offered by the $A$ to $Z$ Guide to the Catholic Faith. ${ }^{130}$ This is also the definition that at least some Neoscholastic commentators had in mind through much of the nineteenth and early twentieth centuries. In contrast, Tischleder used the term in the sense understood by St. Thomas, when the Angelic Doctor described reason as the sometimes fallible but nonetheless formidable faculty of the human intellect to participate in God's eternal

129 Tischleder, "Der katholische Staatsgedanke...," 122-123.

${ }^{130}$ A to $Z$ Guide to the Catholic Faith, ed., Roderick C. Broderick (Nashville: Thomas Nelson Publishers, 2005), 212-213. 
law. The ability of human beings to understand at least part of the eternal law in the ordering of political society is a fundamental underpinning of Catholic natural law doctrine. ${ }^{131}$

Along this line of thinking, Tischleder believed that the Catholic state doctrine can be seen not as a negation or a "no," but as an affirmation - literally, a resounding "yes." Catholicism "is the representative of a whole reality," he insisted. On the one hand, Catholicism stood against the "anti-social, atomized individualism" of liberalism. On the other hand, it stood against "anti-personal, collectivist centralism" embodied in Communism and National Socialism. He concluded by calling on the authority of 2 Corinthians 13:8: "For we cannot do anything against the truth, but only for the truth."132

Both Steinrötter and Tischleder believed that the radicalisms of National Socialism, Communism and Liberalism could be overcome. But, neither of the two offered to identify the representative of the "Catholic state idea" on Germany's existing political spectrum.

131 See St. Thomas Aquinas, Summa Theologica, I-II. Excerpted here from the Political Ideas of St. Thomas Aquinas, edited with an introduction by Dino Bigongiari (New York: The Free Pres, 1953, First Paperback edition 1997), 14.

132 Tischleder, "Der katholische Staatsgedanke...," 126. 


\section{Assessing the National Socialist Doctrines on Race and Religion}

Erhard Schlund has left an extensive record of writings on the subject of National Socialism. To be sure, Schlund's legacy is problematic. As explained in Chapter 6, Schlund drew a distinction between historical Jewry and contemporary Jews. He denounced the latter as materialistic and overly ambitious in Germany's economy, press and culture. While he insisted that the Catholic Church must accept converted Jews as equals, he noted that the CV "is not the Church." The Church, he clarified, represented all Catholics. The CV was only a "group thereof," with a special purpose. It was therefore up to its own members to define the criteria of membership. ${ }^{133}$ (He thereby came close to contradicting the pronouncements of his superiors in Germany's diocesan capitals.) Schlund also found a "positive" quality in the patriotism of the National Socialists. In a number of writings, which were otherwise nearly always critical of his movement, Schlund called on Hitler to "clarify" his position on the Christian religion. He thereby seemingly suggested that other features of Hitler's program might be acceptable. ${ }^{134}$

${ }^{133}$ Dr. P. Erhard Schlund, Ve, O.F.M., "Zur Rassenfrage," Academia 40, Nr 3. (July 15, 1927): 56.

134 Von Erhard Schlund, O.F.M., Ve, CV-Seelsorger, "Die Religion in Programm u. Praxis der Nationalsozialist. Deutsch. Arbeiterpartei," Academia 43, Nr. 3 (July 15, 1930): 56. Erhard Schlund, "Nationalsozialismus und Studentenschaft," Academia 43, Nr. 10 (February 15, 1931): 292-293. 
Nonetheless, from the standpoint of Catholic doctrine and theology, Schlund's criticisms of National Socialism are difficult to overlook. In a 1927 contribution to Academia, Schlund even took the potentially risky strategy (at least from the standpoint of Catholic orthodoxy) of attacking Hitler's racism on its own terms, by resorting to the science of genetics. At the beginning of his article, Schlund suggested that certain racial categories might be scientifically meaningful, in that their defining physical characteristics (he had in mind here specifically skin color) - are perpetuated reliably and predictably through the generations. By the same reasoning, children produced from mixed racial unions diminish or combine these same defining physical features. ${ }^{135}$

But this is not so with other physical features. For instance, continued Schlund, if blonde and brown haired parents produce children, there is no scientifically reliable way of predicting the hair color of the child. Of the so-called racial "sub-categories" he argued, it has proven impossible for anthropology or other scientific disciplines to reach objective agreement on their defining characteristics. Lamented Schlund, attempts to develop a "reliable" racial science have often been

135 Schlund, "Zur Rassenfrage," 56. 
"vulgarized" in the general population. ${ }^{136}$ Although Schlund did not mention them by name, he very clearly had the National Socialists and their supporters in mind.

But, to get bogged down in scientific discussion on the question of race, Schlund contended, missed the point. From the standpoint of Catholicism, race cannot describe the most important constituent of the human person, namely, the soul. Catholic teaching holds that the soul cannot be described by inheritance. The soul is created exclusively by God. Each soul is God's original creation, and each soul is therefore a unique quality. In creating the soul, God operates with unlimited power. Parents have nothing to do with this. This is not to say, qualified Schlund, that souls do not have certain defining features that are shared with the parents, but this is entirely coincidental. He concluded that "from the standpoint of Catholic theology we can accept only this: each soul is an original, and there can be no race in the soul."137

Is biology irrelevant? Of course not, continued Schlund. The body, being the product of air, light, nourishment, climate, upbringing, inheritance and fate, is another matter. Following St. Thomas, when the body is alive, body and soul are mutually dependent. The soul

\footnotetext{
136 Schlund, "Zur Rassenfrage," 53.

137 Schlund, "Zur Rassenfrage," 54.
} 
cannot live on its own. This means that if a good soul finds itself in an ill-fated body (by whatever definition), it is likely, but not inevitable, that it will face the world with limitations. As many good parents discover to their chagrin, this is likewise the case when a poor soul (again, by whatever definition) is lodged in an otherwise perfectly sound body. ${ }^{138}$

Schlund concluded his article by turning to the delicate question of Germany's Jews. The contemporary racial and Jewish questions, he conceded, were linked. In the very same article that seemed so clearly to criticize National Socialist racism on both scientific and theological grounds, Schlund took Germany's Jews to task for their supposedly "destructive influence on religion, ethics, literature, art and political and social life." But, Schlund nonetheless insisted it did not "thereby follow that Jews must be persecuted solely based on their race." $\mathrm{He}$ continued:

The Church's position on the Jewish religion is this: the Jews are recognized as the core of the Church. The Jews are part of the truth, the Church is the truth. Jews are the law. The Church has mercy as the crown of the law. The Jewish religion leads to Christ, the Church is Christ. ${ }^{139}$

At a moment when they found themselves the victims of popular religious fanaticism unleashed by the Crusades, continued Schlund, Pope Calixtus II in 1119 insisted that Europe's Jews not be harmed,

138 Schlund, "Zur Rassenfrage," 54.

139 Schlund, "Zur Rassenfrage," 56. 
ordering by Papal Bull that they be taken under his protection. From the standpoint of dogma, Schlund wrote, the religion of the Jews must be rejected because it has only a part of the truth that was resolved by Christ. But, "morally speaking, no human being may hate another without violating the Golden Rule."140

Schlund continued to write about the question of race and religion in the context of National Socialism until Hitler came to power in 1933 and indeed, at least for a short time after. ${ }^{141}$ In 1930, he continued his assault on Article 24 of the NSDAP party platform and positive Christianity. He also continued to refute National Socialist calls (echoing certain trends in contemporary Protestant theology) to remove the Old Testament from the Bible. Schlund denounced a recent article in the National Socialist press that had characterized the Old Testament as "rotten, immoral and offensive." He also criticized efforts by some contemporaries to appropriate the lessons of the Bible selectively, for instance, separating the Gospels from the writings of

\footnotetext{
${ }^{140}$ Schlund, "Zur Rassenfrage," 56.

${ }^{141}$ According to the CV-Handbuch, Schlund was forced to step down from his position as CV Spiritual Advisor "out of political grounds" sometime in 1933. He remained on with the Franciscans in Munich until both church and monastery were destroyed in 1944. An ailing Schlund attended the first meeting of the resurrected CV in 1947 . He passed away in 1953. CV-Handbuch, Herausgegeben von der Gesellschaft für Studentengeschichte und studentisches Brauchtum e.V. (Regensburg, 2000), 582.
} 
Paul that were supposedly, "foreign, dirty," written in the Jewish spirit and materialist. 142

In response, argued Schlund, "Anyone who seeks to do away with the Old Testament in part or in its entirety from God's revelation is no longer Catholic." He continued: "Christianity in that sense is not Christianity at all." In an obvious dig on one of the essential components of the National Socialist position on religion, Schlund wrote that this is "liberal, atheist," and "not positive Christianity."143

Among Catholic fraternity writers, Schlund was not alone in denouncing the Biblical revisionism of the National Socialists and their allies. In February 1932, Private Docent H. Kaupel of the Unitas Frisia fraternity chapter authored a scripturally supported and detailed refutation of two ideas held by Hitler and many of his supporters, namely, that the New Testament could stand on its own, and that Jesus as a Galilean must have descended genetically from Aryans. ${ }^{144}$ In the opening of his article, Kaupel placed the National Socialist rejection of the Old Testament on par with the heresies of the past centuries. The

${ }^{142}$ Schlund, "Die Religion in Programm...," 56.

${ }^{143}$ Schlund, "Die Religion in Programm...," 56.

144 Among the three Protestant theologians discussed in Robert P. Erickson's

Theologians under Hitler, only one, Emmanuel Hirsch, came out definitively in favor of the "Aryan Jesus" argument, relying on the claim that Galilee after the fall of the Northern Kingdom was inhabited by heathens. The other two theologians under investigation in this study, Gerhard Kittel and Paul Althaus dismissed this idea, even if they supported Hitler for other reasons. Ericksen, 52-53, 115, 164-165. 
idea that the Old Testament is "useless" and "detrimental to any true religion," wrote Kaupel, derived from political, not theological motives. At the same time, in an evident reference to Rosenberg, Kaupel dismissed the idea that the value of Christianity could be tied to German national blood. ${ }^{145}$

Turning specifically to the Old Testament, Kaupel reminded his reader that both the Gospels and the Pauline epistles provided no shortage of evidence attesting to its worth and its integral role in the fulfillment of the prophesy of the messiah. Citing John 5, Kaupel pointed out that Jesus frequently leaned on the teachings of Moses for authority. Kaupel also used Matthew 5:17 to establish an "organic" connection between the Old and New Testaments: "Do not think that I have come to abolish the law of the prophets. I have come not to abolish but to fulfill." Along the same lines, Kaupel called on Matthew 5:18: "... until the heaven and earth pass away, not the smallest letter or the smallest part of a letter will pass from the law." True, conceded Kaupel, 2 Corinthians teaches its reader that a veil lies over the hearts of those who read only Moses. Only through turning to the Lord, that is, accepting Christ, can the veil be lifted. But this veil can be lifted

145 Von Privatdozent Dr. H. Kaupel, Münster, i.W. (A.H. Unitas-Frisia), "Prinzipien zum antisemitischen Kampf gegen das Alte Testament" Unitas 72, Nr. 5 (February 1932): 56. 
through a conscious human decision. The veil does not signify or represent a genetic community of fate, either metaphorically or literally. Kaupel argued pointedly that "anyone looking for racial anti-Semitism will not find it here."146

Turning to the question of Jesus' ancestry, Kaupel leaned on Matthew 15:24 to insist that Jesus was sent "to the lost sheep of Israel." He followed with a more complex engagement with Romans 9, specifically focusing on the passage that reads:

They are Israelites; theirs the adoption, the glory, the covenants, the giving of the law, the worship and the promises; theirs the patriarchs, and from them, according to the flesh, is the Messiah. (Italics added for emphasis.)

True, continued Kaupel, Paul goes on to explain that Christianity must represent something more than a literal community of descent. In the last word, Christianity, like Judaism, embodies something far broader than the descendants of Abraham. Ultimately, concluded Kaupel, following Paul's reasoning, it is "not the children of the flesh who are the children of God, but the children of the promise are counted as his descendents." 147 Yes, Kaupel conceded, Paul reminds his followers that many among the Israelites had rejected Christ. But the logic cannot be reversed. With considerable controversy, Paul released Christian

\footnotetext{
146 Kaupel, "Prinzipien zum antisemitischen Kampf...," 56.

147 The New American Bible (The Catholic Bible Press, 1987), was used in part to facilitate this translation.
} 
followers from the daily ethical obligations of the Jewish religion. In so doing, he made Christianity a largely gentile phenomenon. But this is not to say that Christians can reject Israel. As Kaupel warned, again leaning on Scriptural authority: "Anyone who rejects Moses cannot recognize Christ."148

Kaupel concluded his article by ridiculing Houston Stuart Chamberlain and his ideological descendants. At the turn of the twentieth century, Chamberlain was perhaps the most widely known of all the Aryan racists in Germany, and had been the favored reading of Hitler's supporters. Making a rather straightforward read of the exhaustive genealogies found in Matthew and Luke, Kaupel concluded that one could dismiss easily Chamberlain's claim that Jesus derived from Aryan ancestry. 149

Kaupel closed by reminding his reader of the presence of the Old Testament in Beethoven, in Goethe, of the Psalms in everyday Christian (including both Catholic and Lutheran) practice, and the role of the missals in the holiday season. The language of the Old Testament, he continued, is found everywhere in baptisms, in prayers, in the very first songs of childhood, and in the Eucharist. The idea that the Old

\footnotetext{
148 Kaupel, "Prinzipien zum antisemitischen Kampf...," 58.

149 Kaupel, "Prinzipien zum antisemitischen Kampf...," 58.
} 
Testament could be poisonous to the national feeling, he concluded, "makes us red with shame if we live in the German land." 150

150 Kaupel, "Prinzipien zum antisemitischen Kampf...," 59. 


\section{Conclusion}

On January 30, 1933, President Paul von Hindenburg appointed Adolf Hitler to serve as Germany's new chancellor. The aging war hero had in fact been reluctant to take this step. Relations between Hindenburg and the "Austrian corporal" in the past had been far from cordial. In 1932, Hitler had stood against Hindenburg in Germany's presidential election, thereby compelling the proud general to endure the indignity of running a competitive campaign. For the time being, Hitler's party was given only a minority share of Germany's ruling cabinet. The Weimar constitution continued to function, albeit under emergency conditions that effectively suspended parliamentary responsibility. Most of Germany's important government powers, at least for the time being, were not directly under Hitler's control. Ironically, it was a practicing Catholic and a former Center Party politician, Franz von Papen, who had reassured Hindenburg that Hitler could be controlled under the current arrangement. Papen pointed out that Hitler's party, which had performed spectacularly well at the polls during the past year, could provide Germany's government with badly needed legitimacy, especially from the right. Papen was rewarded for his complicity in the scheme with the Vice Chancellorship. 
Less than a month after Hitler's appointment, Professor A. Timpe, an alumnus of the Unitas fraternity, delivered an address to a local fraternity chapter in Berlin entitled: "The Religious Duties of Unitas in the Present Time." A long-time contributor to the most politically assertive of all of Germany's major Catholic fraternities, Timpe reminded his readers that Unitas had started as a religious organization, with religion as its central principle. The stated goal of Unitas, he explained, was to deepen the worth of "our holy religion," to maintain the unity of the Catholic worldview and the integrity of the community, and finally, to participate in the fraternity based on the apostolic model, that is, to play an active role in society. "Strengthening our Catholic beliefs," he continued, "does not mean participation in the daily struggles of politics." He concluded by warning against the "lava streams of propaganda from unbelievers." "Godless propaganda and the destruction of ethics can find no home in the German lands," he insisted. "Millions of our people recognize that Christianity is once again the cornerstone of life in the nation." Timpe warned his listeners to "struggle against class hatred, and in fact, against hatred of any kind."1

\footnotetext{
${ }^{1}$ Festansprache, gehalten auf der Morgensitzung des U.V. Berlin am 19. Februar 1933 von Hochschulprofessor Dr. A. Timpe, Berlin (A.H. Unitas-Göttingen), "Die religiösen Aufgaben der Unitas in der heutigen Zeit," Unitas 73, Nr. 8/9 (May/June 1933): 8789.
} 
Timpe's address certainly alluded, even if obliquely, to profound changes in German politics. But at no point in his address did Timpe mention the National Socialists or Hitler by name. For at least the first two months with Hitler at the nation's helm, Catholics in Germany's fraternities approached the new state of affairs with caution and circumspection. Germany's Catholic bishops did the same. Through February and most of March, the bishops maintained their prohibition on Catholic participation in Hitler's party.

On March 23, however, the German parliament passed the Enabling Act, which suspended the Weimar Constitution and granted Hitler near dictatorial powers. Five days later, Germany's bishops lifted the ban on Catholic membership in the National Socialist party. ${ }^{2}$ In subsequent years, Germany's Catholic authorities would offer a number of not altogether consistent explanations for this startling turnabout. First, they reminded their followers that their theological tradition had always taught Catholics to obey the legitimately constituted authorities. Whatever his faults, with the Weimar constitution still nominally in place, Hitler's party had received nearly $44 \%$ of the vote in the most recent elections on March 5. Hitler was able to parlay this victory into

\footnotetext{
2 Hans Jürgen Rösgen, Die Auflösung der Katholischen Studenten Verbände im Dritten Reich. Dortmunder Historische Studien. Bd. 1 (Universitätsverlag Dr. N. Brockmeyer, 1995), 173.
} 
securing the passage of the Enabling Act less than three weeks later. Partially because Hitler had made reassurances that he would not attack the Catholic Church, both the Catholic Center and Bavarian People's parties approved. For the Catholic bishops, then, it certainly made little sense to continue to bar Catholic membership in a political party, when that party was now Germany's government. By April, the bishops were also well aware that continued employment in the Reich government depended on membership in Hitler's party, at a time when the German economy was still deeply immersed in the Great

Depression. Finally, in order to secure the consent of the Catholic Center Party for the Enabling Act, on March 23, Hitler had announced to the Reichstag that his government would be willing to "cultivate and develop" improved relations with the Vatican. This would serve as the pretext for negotiations between Hitler's government and the Papacy for the elusive Concordat that Catholic leaders in Rome and Germany's diocesan capitals had long sought. ${ }^{3}$

By April, these negotiations were well underway, with the papal side represented by Eugenio Pacelli, who in 1939 would be elected by the College of Cardinals as Pope Pius XII. In the early 1920s, Pacelli had served as the papal representative to the Bavarian government in

${ }^{3}$ Guenter Lewy, The Catholic Church and Nazi Germany (Da Capo Press, 1964, 2000 edition used here), 65. 
Munich. Perhaps incidentally, in July of 1922, after having taken a strong interest in Catholic university life in the Bavarian capital, Pacelli became a member of a Munich Catholic CV fraternity. ${ }^{4}$

By April 3, 1933, just five days after the bishops lifted their prohibition, both the $\mathrm{CV}$ and $\mathrm{KV}$ fraternities retracted their claim that membership with the NSDAP was incompatible with Catholicism. ${ }^{5}$ As explained in Academia on April 15, the prohibition had been based on the recommendation of the CV Spiritual Advisor and Germany's bishops. On March 28, Germany's bishops had announced that their former warnings against National Socialism were no longer necessary. The bishops had further admonished their followers "to be faithful to the rightful authorities and to fulfill" their civic duty. The article concluded: "We Catholic academics greet this announcement with open hearts."6

The Catholic fraternities had contributed detailed, convincing, and seemingly convinced criticisms of Hitler and his movement before 1933. Starting in April 1933, with the bishops' prohibition against the NSDAP lifted, articles in support of Hitler's government now dominated

\footnotetext{
${ }^{4}$ Specifically, the KDStV Trifels. In the CV's fraternity handbook published in 2000 , Pacelli is listed among important historical figures of the CV. In his biographical page, it is claimed that the historical portrayals of Pius' indifference to Jews during the Holocaust are "historically false." CV-Handbuch, Herausgegeben von der Gesellschaft für Studentengeschichte und studentisches Brauchtum e.V. (Regensburg, 2000), 582. ${ }^{5}$ Rösgen, 173.

6 "CV und Nationalsozialismus," Academia 45, Nr. 12 (April 15, 1933): 351.
} 
fraternity publications. In the May/June 1933 issue of Unitas, Mr. Rüdinger declared that his fraternity brothers stood "on the ground of the national government and its goals!" This was not, he insisted, "because we are making due with the existing situation, but because we are sincere in our enthusiasm." Hitler, "the master builder of the new Reich," intended to unite "race, Volk and religion." Rüdinger believed that an essential element of this goal would be the "proper education" of the people's community. ${ }^{7}$ Without explaining how, Rüdinger believed that the Unitas fraternity would be ideally suited to contribute to this project. ${ }^{8}$

The same issue included an Easter celebration address delivered by Heinz Monzel, a Unitas alumnus from Marburg. Monzel started his address by lauding Hitler and President Hindenburg for beating the enemies of the new government, the Communists and the Socialists, "into the ground." He referred here to the Order of Reich President for the Protection of People and State, decreed by President Hindenburg in the wake of the Reichstag fire on February 28, 1933. With the Ministry of Interior in the hands of his party, Hitler used this decree to arrest, imprison or drive underground the leaders of both the Communists and

\footnotetext{
7 Volksgemeinschaft.

8 Phil. Rüdinger, V.O.P., "Unitas and Zeitenwende," Unitas 73, Nr. 8/9 (May/June 1933): 81-82.
} 
the Socialists. The former had typically been an implacable foe of the Weimar Republic. The latter had been its most consistent supporter. (In 1938, the SS and the German police would use this very same decree to disperse the remaining Catholic fraternities, including Unitas.) Approvingly, Monzel believed that the new Reich would be held together with an "iron fastener." He also believed firmly that Hitler's new government represented no simple restoration of a past state of affairs. "A Volk, our Volk, our beloved German Volk, will once again be a nation. Nation in revolution - Indeed!"9

Both Rüdinger and Monzel made obvious, if not altogether specific references to Hitler's purported foreign policy aims. Rüdinger reminded his readers that in the past 15 years, the Unitas fraternity had kept its feet "firmly rooted in Austria and in the German regions alienated from the Reich by Versailles." Alluding to Ernst Jünger, whose Great War narratives had once been dismissed by Catholic fraternity writers, Monzel declared that "In the storm of steel of the world war, we from the front generation were brought together by blood." In the same breath, he reminded his audience that President Hindenburg "himself realized that he who knows war, must also want

\footnotetext{
9 Worte, gesprochen auf dem Osterkommers des U.V. 1933 in Köln von A.H. Heinz Monzel (U-Marburg), "Der Weg der Unitas," Unitas 73 Nr. 8/9 (May/June 1933): 8284.
} 
peace." But, Monzel insisted, Hindenburg would not believe that the "rights of a nation of millions of people are the same as a neighbor of a hundred thousand." Clearly, Monzel understood that any foreign policy revisionism on Germany's part would come at the expense of Germany's neighbors. Monzel also believed that Hindenburg (still the legitimate head of Germany's government) and Hitler shared the goal of reestablishing Germany as a preeminent world power. ${ }^{10}$

Like Rüdinger and Monzel, yet another contributor to the May/June 1933 edition of Unitas clearly perceived Hitler's new regime to be revolutionary. A theologian, P. Planz argued that Hitler's triumph represented an overcoming of materialism and liberalism, a victory of the "struggle for the inner renewal of the German people and the soul of the German Volk." On this score, Planz insisted that it "is not necessary to emphasize our national commitment, because as Catholic Christians we are well aware of our God-given commandment to support the German people." He pointed out that a long line of Popes had all advocated the overcoming of "liberal individualism." Provocatively, Planz suggested that patriotism - the spiritual, ethical and economic renewal of the German people - and overcoming liberalism were one and the same goal. The goal could be

\footnotetext{
${ }^{10}$ Monzel, "Der Weg der Unitas," 82-84.
} 
accomplished, however, only if the German state were to be based on the eternal, inviolable laws of Christian belief, of Christian ethics, of Christian justice and social peace. There is nothing necessarily radical about this claim. Catholic commentators in the fraternities and elsewhere had been repeating it for a decade. What is remarkable is that Planz believed that Hitler's government shared these goals. ${ }^{11}$

Hitler had profound changes in store for the German student body. As early as February 7,1933 , the Reich granted recognition to the DSt, an entity that had run afoul previously of the Weimar authorities for allowing within its ranks fraternities and other organizations that had insisted on the "Aryan" or racial principle in admitting members. The KV and the Unitas fraternities had withdrawn from the DSt in 1930. On April 6, 1933, Prussia lifted its prohibition on the duel, a practice from which the Catholic fraternities out of religious principle had always abstained. By May 26, 1933, the duel had been legalized throughout the Reich. ${ }^{12}$

More importantly, in late April, the Reich enacted legislation that would implement the principle of Gleichschaltung - or coordination - on Germany's college campuses. Gleichschaltung would require that

11 Theol. P. Planz, "Unitas und Gegenwart," Unitas 73, Nr. 8/9 (May/June 1933): 8586.

12 Rösgen, 173. 
Germany's university associations model their governing structures on the Führerprinzip or leadership principle, thereby terminating the long tradition of democratic student government on German campuses. ${ }^{13}$ In June, Hitler's government declared that Germany's students must be willing to participate in student national work battalions and in mandatory armed sports exercises. ${ }^{14}$ On May 5 and May 8, respectively, the $\mathrm{KV}$ and $\mathrm{CV}$ affirmed their obligation to abide by the principle of Gleichschaltung. ${ }^{15}$ Although Unitas had yet to make a formal announcement, Planz asserted that his fraternity was well prepared to contribute to its implementation. ${ }^{16} \mathrm{He}$ also registered his support for the work battalions and the armed sports camps. ${ }^{17}$

Through 1933, contributors to the KV journal also demonstrated strong support for Hitler's government. They were likewise willing to author extensive and detailed justifications for their willingness to do so. In the June edition of the KV journal, Dr. Freiherr von Pölnitz of Munich again equated Hitler's assumption of power with a national revolution. In contrast to the French, the English and the Russians, he claimed, the Germans are a "disciplined" people who know how to

\footnotetext{
${ }^{13} \mathrm{~A}$ tradition that, ironically enough, had been inaugurated by Germany's nationalistoriented fraternities in the early 1800 s.

14 This act might be seen as anticipating Hitler's later break with Versailles. Versailles had limited the German Army to 100,000.

15 Rösgen, 173.

16 Planz, "Unitas und Gegenwart," 85-86.

17 Planz, "Unitas und Gegenwart," 85-86.
} 
execute a revolution without unleashing a terror. (In fairness, Hitler's blood purge against the SA and other perceived opponents, including prominent Catholics, was still a year away.) Resorting to a quick history lesson, Pölnitz explained that the French Revolution of 1789 had produced a profound rupture between two worlds. Specifically, it had inaugurated an age of economic liberalism, that in turn generated the twin forces of "bourgeois Manchester economics" and "Marxist socialism." Both had conspired to undermine the organic and corporative constitution of traditional European society. Nonetheless, in the first half of the liberal epoch, Bismarck had inherited a "fractured people of thinkers and poets" and had molded Germany into one of the world's leading political, economic and scientific nations. ${ }^{18}$

In the "powerful days" of August 1914, continued Pölnitz, the war had brought together a formerly disunited German people without regard to confession, lineage, age, or class. Unfortunately, the end of the "heroic" struggle in November 1918 would always represent a "stain on German history." During the Weimar Republic, he lamented, traditional cultural connections, religious and ethical concepts and the family had all been assaulted by liberal ideas. The people had become immersed in degenerate art and music, film and the press, all of which

\footnotetext{
18 Von Dr. G. Frh. Von Pölnitz, München, "Katholisch und Deutsch," Akadem.
} Monatsblätter 45, Nr. 7 (June 1933): 289-290. 
were in the hands of proletarian and bourgeois "free thinkers" who operated without restraint. Through the hyperinflation and the radicalization of the petty bourgeois class, Germany's Catholic leaders struggled against the destruction of the nation. Catholicism, insisted Pölnitz, was simultaneously conservative and evolutionary, able to defend Germany from internally hostile powers, and able to accommodate natural changes in German society. ${ }^{19}$

As was the case with the Unitas writers, Pölnitz seemingly affirmed the revisionist foreign policy aims of Germany's new government. He did not, however, take aim at the Versailles settlement of 1919. Instead, he set his sights on another pivotal moment in the history of European international relations that had transpired nearly five decades earlier, ironically enough, in the same city. Although it was technically representative of a German battlefield victory, the Versailles settlement of 1871 had never satisfied Germany's Catholics. For one thing, it had failed to unite all Germans into one Germany. This was especially true as far as the mostly Catholic "south" Germans were concerned. Pölnitz expressed his hope of reestablishing Germany as a "holy Reich," as a "Sacrum Imperium," that is, a national body that

19 Volksfeindlich - a danger to the people, the nation or the race (or all three). often a reference to Jews, the term was also applied by the nationalist fraternities against Catholics before 1914. 
would unify all German speakers in central Europe. This entity would be constituted on the basis of "Christian natural law." Pölnitz's article, long by the standards of the Catholic fraternity journals, ${ }^{20}$ clearly affirmed many of the goals of Hitler and his regime. But for reasons unexplained, it scarcely mentioned either the Führer or his party by name. ${ }^{21}$

An unnamed contributor to the CV journal on June 15, 1933, was not nearly so reticent in lauding Germany's new Führer, however. The writer opened the article by claiming that the National Socialists had just executed the "biggest inner political victory of the century." "The national uprising has been won." The writer admitted that Hitler's victory had caught many Catholics off guard: "The newness of this all has caught one unprepared, has left one speechless." But, insisted the writer, the National Socialist victory should not be seen as a triumph over the Catholic worldview. "This has been proven by the explanation of the German chancellor and the announcement of the German and Bavarian episcopate." Hitler, the writer hoped, would restore respect for authority among Germany's people, especially among the youth. He believed that the new government would revive the sense of

\footnotetext{
${ }^{20}$ Nine pages approximately. Even headlining articles averaged typically no more than 2-3 pages.

${ }^{21}$ Pölnitz, "Katholisch und Deutsch," 293.
} 
responsibility and leadership in the German people. He also hoped that Hitler would replace the juristic, legal, and formal Weimar state with a vital and organic state. As explained in Chapter 5, Catholic writers in the previous decade believed that a German state must be based on more than merely formal laws. An effective state must be able to establish more intimate connections between people. According to the writer, Hitler's plans for Germany were consistent with the ideas taught by Pius XI in his recent encyclical Quadragesimo Anno (1931).22 The unnamed writer took Hitler at his word when the Führer had recently claimed that he saw Christianity as "an unshakable foundation of morality and ethics," and would therefore respect the rights of the Catholic Church. For this reason, following the lead of Germany's bishops, the writer claimed that "we are ready to place our entire strength in the service of national life."23

In his otherwise seemingly unequivocal endorsement of Hitler, the writer ended with one interesting qualification. St. Thomas, he wrote, did teach that race and nation were to be valued. But, the Angelic Doctor would also instruct that "God alone is above all." "This must be recognized," the writer believed.

\footnotetext{
22 In 1937, Pius XI would author Mit brennender Sorge, a denunciation of Nazi racism, even if the document does not mention Hitler or National Socialism by name. 23 "Die nationale Erhebung und der katholische Akademiker, eine Stimme der Jugend," Academia 46, Nr. 2 (June 15, 1933): 36-37
} 
Insofar as National Socialism errs, it errs in race theory. If God exists, he must be the highest. And therefore, the Church as a metaphysical value and as an eternal institution must stand over state, race and nation. ${ }^{24}$

It may never be known if the writer believed sincerely that Hitler would heed the Angelic Doctor's advice and temper his racism in the months and years to come.

On July 20, 1933, Cardinal Pacelli and Vice Chancellor von Papen signed the Reich Concordat, the first formal treaty between Berlin and Rome in the history of modern Germany. Pope Pius XI would ratify the Concordat on September 10. As explained in Chapter 7, the Concordat would enhance the credibility of Hitler's new government abroad. At least in the short term, the Concordat would assuage many of the concerns that Catholic leaders had expressed about Hitler and his movement before 1933. Writing for the August 15, 1933 edition of Academia, Professor Eduard Eichmann conceded that Catholics as a "national minority" had worried that their rights might not be protected under Hitler's new Reich. But, the provisions of the Concordat would guarantee the freedom of confession and the open practice of the Catholic religion. The treaty would likewise allow the Church to administer itself without state interference, and permit free contact between Pope, German bishops, and Catholic lay worshipers.

24 “Die nationale Erhebung...” 36-37 
Eichmann was also happy that the agreement allowed for the preservation of the Catholic theological faculties. Catholic religious education would likewise be continued in the elementary and secondary schools. ${ }^{25}$

Eichmann recognized that the Concordat had come at a price. Namely, Hitler had insisted that the Catholic Center and Bavarian People's parties dissolve. This price seemed well worth paying, however. "Each party" of the now defunct Weimar Republic, he wrote, whether Christian, anti-Christian or neutral, were parties of personalities or pursued individual or class interests. There was a feeling of loyalty to the party, but not a feeling of loyalty to the state. It is fortunate that the state has been saved from parties. The party of political Catholicism has been likewise swept away, but its mission of combating liberalism has been rendered redundant by the national revolution. ${ }^{26}$

Presciently, Eichmann recognized that the Concordat might claim additional casualties, namely, the Catholic fraternities, and specifically, the Catholic CV. The Concordat, he wrote, drew a distinction between purely religious organizations directly under the authority of the Church, and independent organizations that went beyond strictly religious matters. Without a doubt, the CV belonged to the latter

\footnotetext{
25 Von Universitätsprofessor Dr. Eduard Eichmann, Mm, Ae, Bd., "Das Reichskonkordat und wir," Academia 46, Nr. 4 (August 15, 1933): 90-91. Providing spiritual guidance for the sick has long been a mission of the Catholic Church. ${ }^{26}$ Eichmann, "Das Reichskonkordat und wir," 90-91.
} 
category and might therefore be eliminated under the treaty's provisions. But, Eichmann rejected the idea that the $\mathrm{CV}$ should place itself directly under the leadership of Germany's Catholic bishops, a move that might have protected it from Hitler's government. By way of reminder, Erhard Schlund, soon to leave the fraternity, had made precisely this recommendation on May $27,1933.27$ But, "why should the CV" be continually required to prove "its loyalty to the fatherland," argued Eichmann, when the "sacrifice of 1,300 of its members in the last war" should have proved its devotion to the German national cause beyond doubt?28

\section{Accommodation, Capitulation and Dissolution}

Historian Ronald Warloski has described well the fundamental miscalculation made by Germany's Catholics during the first years of the Third Reich. Warloski explains: "The National Socialist movement did not want cooperation, it wanted submission; it wanted every facet of German life coordinated."29 Through 1933 and 1934, Germany's Catholic fraternities continued to adjust and accommodate themselves to the realities of Hitler's new regime. Naively, but not without reason, they believed that their Catholic fraternities could be modified, molded

\footnotetext{
${ }^{27}$ Lewy, 55, 357fn.

${ }^{28}$ Eichmann, "Das Reichskonkordat und wir," 90-91.

${ }^{29}$ Ronald Warloski, Neudeutschland, German Catholic Students, 1919-1939 (The Hague: Martinus Nijhoff, 1970), 153.
} 
and adjusted to any state form that otherwise respected their church. In so doing, they were unable to understand that the powers that determined their survival were never in their hands.

Eichmann himself fell prey to this fallacy when he likened Hitler's regime to an oncoming locomotive. The tactic, he insisted, should be to get on the train so as to steer it into a positive direction. Like many Catholics in Germany, Eichmann was happy to watch National Socialism turn against Bolshevism, which he described as the "antichrist incarnate." $30 \mathrm{He}$ was evidently unable to realize that Hitler wanted to do more than eliminate obvious enemies of the Reich. The National Socialist regime, as patriotic Catholics were to discover to their chagrin, also intended to eliminate any force in German society that would not affirm loyalty to Germany's national cause on its terms.

In the case of Germany's Catholic fraternities, the desire to play by the rules, as Catholic theology had seemingly taught, turned out to be a fatal liability. In July 1933, the Catholic CV came under new leadership. Seeking to comply with Hitler's order to coordinate German university life, Edmund Forschbach promised that the CV would abolish all "democratic and parliamentary" decision-making features, reconstitute itself based on the Führerprinzip, and place all of its

\footnotetext{
30 Eichmann, "Das Reichskonkordat und wir," 90-91.
} 
chapters unconditionally under a centralized leadership. Looking on the bright side of the recent dissolution of the Catholic Center Party, Forschbach claimed: "now that Catholicism has released itself from party politics it can once again bind the revolutionary and conservative traditions." Catholics and Protestants, promised Forschbach, would build the Third Reich together. He concluded: "Long live the CV; long live the greater German Reich, Heil to our leader, Adolf Hitler!"31

In the revised $\mathrm{CV}$ constitution that appeared in the October/November 1933 edition of Academia, Article I read: "The CV... is an association of German students of the Catholic confession with the purpose of educating its members in the meaning of the National Socialist worldview." Article 3 of the constitution limited fraternity membership to men of German descent and German mother tongue. The constitution did not use the word "Rasse" or "race" to clarify what was meant by German descent. Rather, it used the broader and seemingly more nebulous term "Abstammung." The new constitution likewise did not address the question of converted Jews that had bedeviled fraternity relations on German campuses through the 1920s. The constitution did, however, threaten to expel members who took "non-Aryans" as wives. On the cover page of the same issue in which

31 Edmund Forschbach, "Aufruf des Führers an den CV," Academia 46 (July 15, 1933): 58. 
the revised constitution appeared, the CV had visually amalgamated its traditional symbol, the black eagle and a sword, with the swastika. ${ }^{32}$

Germany's Catholic fraternities might renounce Catholic politics and continue to function. Indeed, as Chapter 4 should make clear, the fraternity leadership had never been comfortable taking a stand on national politics, even when rank-and-file members after World War I very much insisted that they do so. But, the fraternities certainly could not give up their Catholic identity, at least without rendering their purpose redundant. This is precisely what worried Erhard Schlund when he proposed, unsuccessfully, that the CV be placed directly under Church control in 1933.33 Even "CV Führer" Forschbach, who otherwise went out of his way to pledge his fraternity's support for Hitler, insisted that "the CV is and remains Catholic." 34 Tellingly, even after the duel had been legalized by the Reich in May 1933, the revised CV constitution that appeared later in the year continued to renounce the practice "out of religious grounds." 35 By way of reminder, the refusal to duel had been one of the signature points of distinction and animosity

\footnotetext{
32 "Der CV, Cartellverband der katholisch Deutschen Studenten-Verbindungen, ist ein Bund deutscher Studenten katholischen Bekenntnisses zur Erziehung seiner Mitglieder im Sinne der nationalsozialistischen Weltanschauung." Edmund Forschbach, "Die Verfassung der CV," Academia 46, Nr. 6/7 (October/November 1933): 147-148.

${ }^{33}$ Lewy, 55, 357fn.

${ }^{34}$ Forschbach, "Aufruf des Führers an den CV," 58.

${ }^{35}$ Forschbach, "Die Verfassung des CV," 147.
} 
between the Catholic fraternities and their nationalist counterparts for nearly a century.

On February 7, 1934, the Reich banned all university organizations that based themselves on the confessional principle. Anticipating this move a week earlier, the CV, the KV and the Ring had already renounced their Catholic confessional affiliation on January 31. The Unitas organization followed suit on February 23, 1934. On October 27, 1935, the CV dissolved itself, as explained by fraternity historian (and one of the current editors of Academia) Norbert Sklorz, without having been forced to do so explicitly by the National Socialist regime. ${ }^{36}$ A rump association of "Old CV members" continued on for another three years. The KV dissolved itself on November 20, 1935. On October 10,1936 , the Unitas fraternity met in Würzburg and tried to reconstitute itself as a "civil" association. As Hitler and the Nazi authorities continued to shut down hundreds of lay Catholic press entities throughout Germany, Unitas sold off its publishing organ on December 29.37

On June 25, 1938, on the occasion of Germany's Anschluss or union with Austria, Heinrich Himmler and the Chief of the German

\footnotetext{
36 Norbert Sklorz, Die politische Haltung der Academia 1918-1935. (Würzburg: Veröffentlichung des Archivvereins der Markomannia, 1980), 63.

${ }^{37}$ Rösgen, 173.
} 
Police announced that, based on Section 1 of the Order of Reich President $^{38}$ for the Protection of People and State of February 28, 1933, they were banning once and for all Germany's Catholic fraternities. In their written announcement, among other things, the SS and the German police authorities alleged that the Catholic fraternities in the old Reich had been the representatives of the Center Party. Even after the Gleichschaltung of 1933 to 1938 , the announcement read, members of the Catholic fraternities were engaging in subversive relations with their counterparts in Austria. (The letter did not elaborate.) In Austria, the Catholic fraternities, which were also to be banned, had allegedly supported the previous regimes of Engelbert Dollfuss and Kurt von Schuschnigg. ${ }^{39}$ On July 6, 1938, the Reich and Prussian Interior Ministry codified the decision, and singled out the prohibited Catholic fraternities by name. These included, among others, the $\mathrm{CV}$, the $\mathrm{KV}$, Unitas, the Ring, and the Union of Catholic Female Student Organizations of Germany. The edict likewise prohibited the formation of any new organizations that represented the same or similar goals. 40

\footnotetext{
38 Hindenburg had been dead for nearly 4 years (August 2, 1934), but in the meantime, Hitler had combined the offices of Chancellor and President. ${ }^{39}$ This might come as no surprise; both Dollfuss and Schuschnigg were CV alumni 40 Peter Stitz, Der CV 1918-1938. Der hochschulpolitische Weg des Cartellverbandes der Katholischen deutschen Studentenverbindungen (CV) vom Ende des 1. Weltkrieges bis zur Vernichtung durch den Nationalsozialismus (Munich: Herausgegeben von der Gesellschaft für Studentengeschichte und studentisches Brauchtum e.V., 1970), 382383.
} 


\section{The Legacy of World War II in the Context of National Rebuilding}

On November 10, 1994, Pope John Paul II compiled a list of prominent Catholics who had been martyred in the twentieth century. The CV Handbook of 2000 identifies twenty-seven "Cartel brothers" found on this list. Twenty of these victims met their end in the Third Reich. ${ }^{41}$ Among these, Eugen Bolz, a longtime servant of the Weimar Republic, was arrested and executed in the aftermath of the failed attempt on Hitler's life in the summer of $1944 .{ }^{42}$ According to another $\mathrm{CV}$ publication, Bolz belonged to a circle of resisters headed by Carl Friedrich Goerdeler, former mayor of Leipzig. Goerdeler and his circle had worked with Lieutenant General Ludwig Beck on plans for the administration of Germany, in the event of Hitler's forcible removal from power. The circle included CV alumni Hans Lukaschek and Otto Lenz, both of whom would go on to play founding roles in the Christian Democratic Union (CDU) after the war. ${ }^{43}$ Those brought before the Reich People's Court in the aftermath of the assassination attempt also included KV alumnus Josef Wirmer. ${ }^{44}$

\footnotetext{
41 The other seven met their end serving the German Army as priests on the eastern front during the last years of World War II.

42 CV-Handbuch, 532, 600.

${ }^{43}$ Widerstand und Verfolgung im CV. Die im zweiten Weltkrieg gefallenen CVer. Eigenverlag von der Gesellschaft für Studentengeschichte und studentisches Brauchtum e.V. (Munich, 1983), 13.

${ }^{44}$ http://www.kartellverband.net/index.php?id=89 (accessed 06/18/2007)
} 
Many more prominent Catholic fraternity members survived the Third Reich and World War II. These included the first post-World War II Chancellor of the Federal Republic, Konrad Adenauer. When Adenauer took the remarkable step of seeking to heal his country's rift with its historical enemy on the west bank of the Rhine, his French counterpart turned out to be another German Catholic fraternity alumnus, Robert Schuman. Born in Luxembourg to a family hailing from Lorraine origins and educated in Berlin, Munich, Bonn and Strasbourg in the decade before World War I, Schuman bears testimony to the unusual eclecticism of his Unitas fraternity. Evidently fond of his fraternity memories, Schuman continued to pay dues to the Berlin chapter of Unitas even after World War II. 45 Prior to his death in 1963, Schuman asked that he be buried with both the French tricolor and the flag of his Unitas chapter. ${ }^{46}$

\footnotetext{
45 Heinz-Hermann Elting, Vizepräsident des Institut Saint Benoît, Patron de IEurope, "Aus Christlicher Überzeugung zur Europäischen Einigung, Robert Schuman, erster Präsident des Europïschen Parlements (1958-1960) - based on a lecture given on the occasion of the $30^{\text {th }}$ Congress of the Associatio Sanctus Benedictus Patronus Europae on May 22, 1998 in Cerlvaux, Abtei St. Maurice. Dominu - Universite Dominicaine Bibliothèque en ligne, 8. http://biblio.domuni.org/europe/robertschuman/robertschuman de.pdf (accessed $07 / 27 / 2007)$

46 Rösgen, 60. In 1965, a Unitas fraternity chapter in Schuman's namesake was founded at the newly opened university in Bochum. Christof Beckman, "Vor 40 Jahren: Gründung der UNITAS Robert Schuman in Bochum Festrede von Bbr. Karl Fürst zu Löwenstein. http://www.unitas-ruhrania.org/seite68.htm (accessed 07/27/2007).
} 
In his long tenure at the head of West Germany's government, Adenauer had a number of Catholic fraternity allies at his side. One of his earliest collaborators, a founder of the CDU and a long time federal minister, Heinrich Krone, pledged the Unitas fraternity in Münster in 1914 and was a student member during and after the First World War, moving on to Göttingen and then Berlin. Krone served his party in the Bundestag until 1969.47 Another Catholic CV fraternity alumnus who spent his university years during the Weimar Republic, Heinrich von Brentano also played a founding role in the Christian Democratic Union (CDU). Brentano served as German Foreign Minister from 1955 to 1961. He also chaired the CDU party delegation in the West German Bundestag. CV alumnus Heinrich Lübke, who finished his studies after earning the Iron Cross in the First World War, served as West German Federal President from 1959 to 1969.48 Yet another founder of the CDU, Lenz, began his university studies in 1921 in Freiburg. There, he pledged the local KDStV Arminia fraternity. After earning his law degree in 1925, Lenz served in the Prussian Justice Ministry. He refused to join the NSDAP as required by Hitler's new civil service law. In 1934, Lenz took his boss in the Justice Ministry to task for his

${ }^{47} \mathrm{http}$ //www.unitas.org/ (http://webedition.unitas.org/cgibin/lexikoneintrag?druck=18iid=/unitas/wir/lexikon/krone.html) (accessed 06/18/2007) 48 CV-Handbuch, 567. 
duplicity in legalizing the Röhm blood purge. In 1944, the Gestapo arrested Lenz in the aftermath of the attempt on Hitler's life. He was interred in Brandenburg starting in January 1945, but managed to survive the war. Starting in July of the same year, Lenz worked with Krone, Jakob Kaiser, Ernest Lemmer and Andreas Hermes to establish the CDU branch in Berlin. Starting in 1951, he served as a state secretary in Adenauer's chancellor's office. Lenz remained a dedicated public servant to the Federal Republic, as he would explain, because the experience of Weimar had demonstrated to him that the "selfprojection of the state," an insufficient understanding of democracy and an aversion to politics in the masses could have disastrous consequences. 49

Catholic KV alumni likewise could be found in the leadership of the Federal Republic. Along with Adenauer, the KV contributed no fewer than six executives of the federal Länder or states. These included Alfons Goppel, Minister President of Bavaria and Hanns Seidel, a founding figure of the Christian Social Union (CSU). The Hanns Seidel Foundation, founded in 1967, continues to be active in German politics, and operates with the stated goal of supporting "the

49 Widerstand und Verfolgung im CV .., 131-133 
democratic and civic education of the German people on a Christian basis."50

After 1945, Catholic fraternity members also contributed heavily to the Catholic hierarchy, in Germany and beyond. The KV can claim among its noteworthy alumni the current Pontiff Benedict XVI, known before his election on April 19, 2005, as Cardinal Joseph Ratzinger. Born in rural Bavaria in 1927, Ratzinger entered seminary school in 1939 , on the eve of World War II. In 1943, he manned anti-aircraft batteries in Munich. At the end of the war, he found himself in an American prisoner of war camp. From 1946 to 1951, he continued his theological studies in Munich and Freising, where he joined a local KV fraternity chapter. In 1951, Ratzinger was ordained to the priesthood by Munich Archbishop Cardinal Faulhaber. Twenty-six years later, in 1977, Ratzinger himself was the Archbishop of Munich.

Among his important theological influences from the 1930s, Ratzinger counted Romano Guardini, Professor of Theology at the University of Berlin, and Michael Schmaus, Chair of the Theological Faculty at the University of Münster. ${ }^{51}$ In 1933, Schmaus was the featured speaker at a conference of Catholic theologians, where he

50 http://www.hss.de/homepage-e.shtml (accessed on 06/18/2007)

51 Zachary Hayes, O.F.M., Professor of Historical and Doctrinal Studies, Catholic Theological Union, "Pope Benedict XVI: Joseph Ratzinger," http://learn.ctu.edu/Reflections and Readings/Pope Benedict XVIx Joseph Ratzing er .html (accessed 06/18/2007) 
emphasized the ideological affinities between Catholicism and National Socialism. ${ }^{52}$ Robert Krieg writes that Schmaus belonged to Papen's association, Kreuz und Hakenkreuz (Cross and Swastika) but "otherwise had little to do with the Nazi movement." 53 After World War II, Schmaus taught at the University of Munich until 1963.

Guardini, on the other hand, consistently criticized National Socialism through the 1930 s. For this reason, he was finally dismissed from his academic chair in 1939. Guardini's theology had been very popular among young Catholics during the Weimar period. After 1945, Guardini played an important role in moving the Church away from the Neoscholastic orthodoxy that had prevailed for decades. Between 1962 and 1965, the call for change in Catholic theological thinking bore fruit in Vatican II, a council which inaugurated one of the most profound changes in doctrine and liturgical practice in the history of the Catholic Church. Trying to emphasize the Church as a sacred body by softening some of the hard boundaries between cleric and lay worshipper, among other things, Vatican II transformed the traditional Catholic mass.

From 1965 onward, priests typically face the congregation, rather than

52 Bericht der "Westdeutsch. Akadem. Rundschau," 4 Julifolge Nr. 15, 2 10-11 über den Vortrag von Professor Dr. Schmaus vor der Fachschaft der kathol. Theologen a.d. Universität zu Münster, "Begegnung zwischen katholischen Glauben und nationalsozialistischer Weltanschauung," Academia 45, Nr. 4 (August 15, 1933): 9192. Krieg, 71.

53 Robert A. Krieg, Catholic Theologians in Nazi Germany (New York and London: Continuum, 2004), 71. 
lead the service with their backs turned. Vernacular languages have largely replaced Latin in the liturgy. Complicated Gregorian chants have given way to more dynamic if less predictable lay participation, including singing hymns and playing contemporary music, reading passages from the Bible and assisting in the administering of the Eucharist. Vatican II also renounced officially the doctrine that Jews were historically or collectively responsible for the crucifixion of Christ.

\section{Continued Questions about the Third Reich and Germany's Past}

A number of prominent Catholic fraternity members from the Weimar period later faced questions about their activities during the Third Reich and World War II. In its handbook, the CV lists among its "important" alumni Joseph Lortz, who completed his doctoral degree at the University of Bonn in 1920 and became a prominent Catholic theologian in the 1930s. Among other things, Lortz was known for his belief that modernity had inaugurated the decline of Western civilization. He is also known for having promoted ecumenism (reconciliation) between Germany's Protestants and Catholics. In 1933, Lortz welcomed Hitler's triumph as a fundamentally positive rupture in the history of the Western world. He joined the NSDAP on May 1, 1933 and like Schmaus, worked with the Cross and Swastika and Papen's Active Community of Catholic Germans. In a pamphlet he published in 
October 1933, Lortz emphasized the ideological points of congruity between Catholicism and National Socialism, including their common hostility towards Bolshevism, their opposition to atheism, and their emphasis on community. ${ }^{54}$

The CV Handbook of 2000 explains that in 1935, Lortz was called to serve as a Professor of Theology at the University of Münster. Fifteen years later, in 1950, he became a Professor of Western Intellectual History at the University of Mainz and a cofounder of the new Institute for European Intellectual History in the same city. Without explaining what happened between 1935 and 1950, the CV Handbook goes on to describe Lortz's long and prolific scholarly career until his death in 1975.55 Narrative black holes like this are not necessarily uncommon in the post-1945 reconstruction of German history.

To fill in the gaps, Robert Krieg writes that the faculty at Münster believed that Lortz had been assigned to the university in 1935 by Reich Minister of Education, Bernhard Rust, to reward Lortz for his loyalty and to punish his predecessor, Georg Schreiber, a former Center Party activist. In 1945, Lortz faced de-Nazification proceedings from the British occupation authorities. He had to wait until 1948 before being granted permission by the provisional West German government to

\footnotetext{
${ }^{54}$ Krieg, 63-64.

55 CV Handbuch, 566.
} 
teach at a university. By that time, the University of Münster had reinstated Schreiber, effectively leaving Lortz without a job. 56

At his de-Nazification hearing in 1945, Lortz maintained that there were elements in the National Socialist program, including authority, community and faith, that were both consistent with prevailing Catholic theology and "necessary for the strengthening of a spiritual religions rebirth if they were developed in the right way." While later known for his efforts to call attention to the "horrific mass crimes" committed by the Third Reich against Jews, Lortz evidently never delved into his personal sojourn with Nazism publicly. In a 1959 lecture in Luxembourg, he remarked cryptically: "Whoever has never been scalded in the service of truth and righteousness has not grasped life properly." 57

Other prominent figures on Germany's postwar political landscape encountered similar quandaries. As of this writing, the website for the KV lists Kurt Georg Kiesinger as one of its prominent alumni. ${ }^{58}$ Kiesinger joined the NSDAP early, in 1933, while still a member of the KV's Askania-Burgundia chapter. From 1940 until the end of the war, Kiesinger worked in the propaganda department of the

\footnotetext{
$56 \mathrm{Krieg}, 67,76-82$

$57 \mathrm{Krieg}, 76-82$

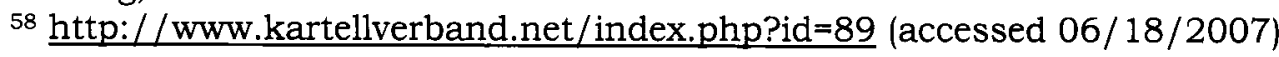


Third Reich's foreign ministry. After the war, Kiesinger went on to enjoy a successful career with the Christian Democratic Union (CDU) in the state of Baden-Württemberg. From 1966 to 1969, Kiesinger served as Chancellor in a coalition government with SPD Chair Willy Brandt (who ironically enough, was in resistance to National Socialism and fought against the Third Reich in World War II). Through his three years at the helm of the German government, Kiesinger faced continuous attacks from anti-Nazi activist Beate Klarfeld, who spoke out against the chancellor at student anti-government demonstrations during the turbulent late 1960s and heckled (and in the latter case slapped) Kiesinger both in the West German Bundestag and at a CDU Party Congress in 1968. These allegations dogged Kiesinger until the "Grand Coalition" with the SPD came to an end in 1969.

\section{The Fraternities and the Post-1945 Catholic Milieu}

In 1935, a twenty year old butcher's son enrolled at the University of Munich. Franz Strauss joined the National Socialist student union in 1938 , as his forgiving defenders would say, because membership was required. Before frostbite relegated him to home front duty in 1942, Strauss served the German Army on both the eastern and western fronts. After the war, Franz Joseph Strauss (he changed his name immediately after the war's conclusion) became one of the longest 
standing fixtures in German national politics. Among other high ranking positions, Strauss headed the Ministry of Nuclear Energy in 1955, and starting in 1956, the Ministry of Defense, where he oversaw the reconstruction of West Germany's military. In 1962, the Spiegel affair, perhaps the most notorious political scandal in post-World War II West German history, sidetracked, but did not derail Strauss' career. After being investigated for his role in ordering police raids on Spiegel offices after the magazine had published a highly critical article on his Defense Ministry, Strauss seemingly destroyed his political future by making the remarkably ill-advised remark that he had been treated like a "Jew who had dared appear at an NSDAP party convention." After resigning from Adenauer's government (Adenauer himself was compelled to step down in the following year), Strauss revived his stature, however. By 1980, Strauss had become the most formidable power broker in the two-headed electoral force that was known nationally as the Christian Democratic Union (CDU) and in Bavaria as the Christian Social Union (CSU), even if he lost out to SPD leader Helmut Schmidt in Germany's national elections in that year.

Along the way, the "uncrowned king of Bavaria," 59 or the "unchallenged champion of the German right," 60 as Strauss came to be (Malden, Oxford and Carlton: Blackwell Publishing, 2002), 139, 160-161. 
known, found the time to advocate on behalf of his Catholic fraternity alma mater, the CV. In 1986, a survey of Germany's fraternities featured Strauss as a representative of the CV. Writing on behalf of his alma mater, Strauss called on its members to steel themselves against "cultural relativism," "self-doubt," "cultural-revolutionary threats," "spiritual sickness" and "demoralizing crimes." 61 This language might have found itself right at home in the 1920s. Strauss was actually calling on his alma matter to serve as the "vanguard" against the explosive student counter-cultural movements of the late 1960s and early 1970s.

Had the Catholic fraternities taken Strauss' advice literally or too seriously, they might well have gone the direction of the vast apparatus of Catholic organizations described by historian Mark Edward Ruff. According to Ruff, after 1960 the "vibrant and robust" German Catholic subculture of the past century was no longer able to "win the hearts and minds of young men and women." Agreeing with Uta Poiger, Ruff concedes that "leading voices" in post-1945 Germany (including "leading Catholics") tempered their hostility towards modern culture

60 Dietrich Orlow, A History of Modern Germany, 1871 to present, Third Edition (New Jersey: Prentice Hall, 1995), 290.

61 Horst Grimm and Leo Besser-Walzel, Die Corporationen: Handbuch zu Geschichte. Daten.Fakten.Personen, (Frankfurt am Main, 1986), 21. 
that had once so effectively mobilized (and polarized) Germans politically before the Third Reich. But, after 1960, writes Ruff, Germany's Catholics nonetheless left the Church and its auxiliary institutions "in droves," thereby unwittingly ending the confessional rift that had characterized German politics and society during the previous century. Between 1954 and 1964, the prized youth organizations of the Catholic milieu, according to Ruff, witnessed an erosion of their membership by approximately 50 percent. ${ }^{62}$

In fairness, Ruff admits that the organizations under his investigation comprised, at most, 30 percent of German Catholic youth. His paradigm does not appear to describe very accurately the Catholic fraternities. As of this writing (2007), Germany's national Catholic fraternities, all of which reconstituted themselves in the western zones of occupation after World War II, appear to be alive and very well, even if the number of active student members has declined somewhat from the Weimar years. ${ }^{63}$

Allowed to reconstitute itself as early as 1947 , the Unitas fraternity currently claims 900 active student members in all faculties

\footnotetext{
62 Mark Edward Ruff, The Wayward Flock, Catholic Youth in Postwar West Germany, 1945-1965 (Chapel Hill and London: The University of North Carolina Press, 2005), 114.

63 The Soviets would not allow any pre-World War II university organizations to form under their zone of occupation. The Catholic fraternities in the "new five Bundesländer" began to reconstitute themselves in the early 1990s, under western leadership.
} 
and disciplines. Its alumni number approximately 7,000 , organized in approximately 200 associations and circles. ${ }^{64}$ The KV likewise reconstituted itself in 1947. After Germany's defeat in 1945, explains the KV's website, many members "placed their full strength in support of the new Federal Republic" as chancellors, as state executives and as federal ministers. The KV survived National Socialism, it continues, because Nazi violence and dictatorship were unable to destroy its basic principle of friendship. During the Weimar years, the website admits, many $\mathrm{KV}$ members remained rooted in the essentially conservative mindset of the Kaiserreich. They nonetheless supported Weimar. In 1933, their chair, Center Party politician and former Chancellor Wilhelm Marx, did what he could to hinder the coordination of the fraternity after Hitler came to power. During the Third Reich, the KV remained a "thorn in the eye" of the regime, as evidenced by the regime's decision to outlaw the fraternity in 1938.65

Many postwar KV fraternities were rebuilt literally in ruins. Of its mission today, the KV explains:

You will find KV members in practically every German university. There, students of all majors have come together to learn, to study and to celebrate. For example, they attend lectures from well-known professors, they go on tours of business and factory enterprises, they go

64 http://www.unitas.org/ (accessed 06/18/2007)

65 http://www.kartellverband.net/index.php?id=89 (accessed 06/18/2007) 
snowboarding, or water skiing or they meet up for evening grill outings, parties and much more. KV members unite the orientation and principles of religion, scholarship and friendship. They have assembled themselves under the roof of a powerful organization. 66

As a "living constituent" of the Church and society, the KV claims to stand firm by its traditions, but also remains open to reform. Among other things, since the student movement of the 1970s, the organization claims to be more willing to accept input from younger members, thereby hoping to dismantle old generational barriers. ${ }^{67}$ Considering the differing responses to World War I, the republic, German party politics, German nationalism and Nazism, the preceding discussion should make clear that, at least during the Weimar years, generational disparities in the Catholic fraternities could at times be acute.

Allowed to reconstitute itself on the national level in 1950, the CV remains Germany's largest Catholic fraternal organization with 6,000 students among 32,000 members, represented in 126 chapters. The CV is a member of the much larger Cartel of Christian Student Fraternities (EKV). Described as Europe's single largest association of students and scholars, the EKV includes 120,000 scholars and students in 660 individual associations. The central organizing principle of the $\mathrm{CV}$ remains Catholicism. As its website explains: "its members are

66 http: / www.kartellverband.net/index.php?id=88 (accessed 06/18/2007)

67 http://www.kartellverband.net/index.php?id=89 (accessed 06/18/2007) 
Catholics; they are engaged in church, state, society and study." It continues: "The $\mathrm{CV}$ and its members constitute their society... on the principles of basic Christian values." 68

Germany's Catholic fraternities appear to have appropriated successfully the post-modern means of mass communication. Today, the most recent editions of Academia, the Akademische Monatsblätter and the Unitas journals are available on the Internet, free of charge, in full-color, downloadable in Adobe Acrobat format. In the early 1920s, gothic script classified advertisements ${ }^{69}$ solicited loans to tide fraternity brothers over the hard times of hyperinflation. Today, the fraternity newspapers advertise vacations in Turkey. The CV still claims as its alumni Catholic luminaries of the nineteenth and early twentieth centuries Georg von Hertling and Ludwig Windthorst. It can also claim Thomas Gottschalk, legendary German television host and a frequent resident of Santa Monica, California. ${ }^{70}$

In contrast to their Weimar predecessors, none of the fraternity publications seem to delve too deeply into partisan German politics. The January 2007 edition of Unitas includes several articles in favor of

${ }^{68}$ https://www.cartellverband.de/pub/b/frame.asp?m=20 (accessed 06/18/2007)

69 For brief periods in the early 1920 s, British, French and Belgian occupation authorities insisted that the fraternities revert to the standard typeface so that military intelligence would be able to read them. After this prohibition was dropped, all fraternity journals (save Unitas) reverted to the old Gothic script.

$70 \mathrm{https}$ // www.cartellverband.de/pub/b/frame.asp?m=41\&ds=33 (accessed 06/19/2007) 
European integration, however. To prove its point, the publication includes an article featuring Pope Benedict XVI under the caption: "Christianity, Spirit of the Continent: Benedict XVI on the future of the European Union." A later article features a meeting of Germany's Catholic bishops under the title: "Europe: Responsibility before God and Humanity."71 The May 2006 edition of Academia includes a biting critique of America's War on Terror, authored by Norbert Sklorz. ${ }^{72}$ Sklorz, by way of reminder, in 1980 authored a concise assessment of his fraternity's response to both the Weimar Republic and National Socialism. Academia, the Akademische Monatsblätter and Unitas all covered the first visit of Benedict XVI to Germany in 2006 following his election by the Vatican in the previous year. Featuring a photograph of the Pontiff, standing next to a color-wearing leader of the Regensburgbased CV KDStV Rupertia fraternity chapter, an article caption in Academia reads: "Here, I am truly home."73

\section{Epilogue}

Through the Weimar Republic (1918-1933), Catholic commentators in the fraternity journals and elsewhere insisted that the

\footnotetext{
71 Unitas 147 (February 2007).

72 Von Norbert A. Sklorz (Gbg), "Der Krieg gegen den Terror ist gescheitert," Academia (May 2006), 280.

73 Von Michael Schörnig (Rup), "Der Papst in Bayern: "Hier, bin ich wirklich zu Hause" Academia (May 2006), 280.
} 
Christian religion play a more meaningful role in German public life. Many continued to believe that Germans were failing their God, oddly enough, at precisely the moment when a new constitution had granted Catholics full civic equality, and at precisely the moment when Catholic institutional life in Germany was as resilient as ever. Nonetheless, they judged that Germany's new republic had failed to constitute German society based on the principles of Catholic natural law and prevailing Catholic theology. The vast majority of Catholics, however, refused to turn against their republic through the 1920s and early 1930s, in part, because their theological tradition had counseled against it. Unfortunately, in 1933, that very same theological tradition did not provide adequate defensive ammunition for at least some Catholics, who were willing to take the promises of National Socialism sincerely and seriously.

As the preceding discussion should make clear, the very same Catholic fraternity members who participated in fraternity life during the Weimar years either as students or active alumni played a founding role in the reconstitution of the Federal Republic of Germany after 1945. In no small measure due to their influence, the Federal Republic of Germany continues to collect taxes for the Protestant and Catholic Churches. Catholic theology departments are a fixture in Germany's 
institutes of higher education. The exclusively confessional schools in Germany are now largely a legacy of the past, in part, ironically enough, because Catholic parents after 1945 believed that these schools were reinforcing the perception of Catholic inferiority. Nonetheless, students in Germany's public primary and secondary schools are still afforded the right (but not the obligation) to receive religious instruction in the classroom. Seemingly in accordance with a long trajectory of Catholic theology that found a voice both in Rerum Novarum (1891) and Quadragesimo Anno (1931), the German social welfare state is as expansive (if overburdened) as ever. The institutions of private property and basic human rights in Germany appear to be firmly intact. Germany is under no threat from counter-systemic ideologies. German politics is still defined by parties. But, in profound contrast to the Weimar years, all of the competitive vote-getting parties appear to share the same consensus in support of the German Federal Republic, its constitution and its values.

Through the Weimar Republic, Catholic fraternity writers continued to insist that Catholicism should offer a viable state doctrine that would bind the German national community meaningfully, organically and genuinely. They believed that Catholicism could provide a fourth way out of the heresies of the modern world, including 
Liberalism, Marxism and National Socialism. Of course, in National Socialism, their hopes that Germany would be reconstituted along lines consistent with the "Catholic state form" were bitterly disappointed, as even Hitler's Catholic supporters admitted after 1945. When the Federal Republic of Germany constituted itself in 1949, Catholics for the first time in their modern history found themselves in a state of near demographic parity vis-à-vis their Protestant counterparts. ${ }^{74}$ But, no explicitly Catholic party materialized to represent their interests. Dissolved in 1933, the Center Party did not revive after 1945. Noel Cary is right that insular Catholic politics, so vibrant during the persecution of the Kaiserreich, was ill-suited for Germany's post-World War II realities. Germany's Catholic leaders (including influential clerics) generally had the foresight to recognize this. ${ }^{75}$ Catholics from that point forward found their home in an interconfessional party (and its Bavarian sister) that dominated German politics for the next twenty years. Most of its leading members were alumni of the Catholic fraternities. The days of CDU dominance in German national politics are long over. Nonetheless, the resilience of Germany's Catholic

\footnotetext{
74 Their numbers were bolstered by millions of mostly Catholic refugees from Poland and Czechoslovakia. Stronger Protestant majorities prevailed in the German Democratic Republic (GDR).

${ }^{75}$ Noel Cary, The Path to Christian Democracy: German Catholics and the Party System from Windthorst to Adenauer (Cambridge and London: Harvard University Press, 1996).
} 
fraternities on Germany's college campuses would seem to testify that Catholicism remains a meaningful force in Germany today. 


\section{Bibliography}

\section{Secondary Sources}

Altgeld, Wolfgang. "Religion, Denomination and Nationalism in Germany." In Protestants, Catholics and Jews in Germany. 18001914. Helmut Walser Smith (ed.) Oxford and New York: Berg, 2004.

Amery, Carl. Capitulation: The Lesson of German Catholicism. New York: Herder and Herder, 1967.

Anderson, Margaret Lavinia. Windthorst: A Political Biography. Oxford and New York: Oxford University Press, 1981.

Anderson, Benedict. Imagined Communities: Reflections on the Origin and Spread of Nationalism. London and New York: Verso, 1991.

Anonymous. The Persecution of the Catholic Church in the Third Reich. Facts and Documents Translated from the German. Gretna: Pelican Publishing Company, 2003.

Becker, Winfried. "Kirche und Staat. Ansätze zur Neubestimmung ihres Verhältnisses in der Kultur- und Konkordatspolitik der Weimarer Republic." Zeitschrift für bayerische Landesgeschichte Bd. 49 Heft 1 (1996): 169-185.

Berghahn, Volker R. Imperial Germany 1871-1914. Providence and Oxford: Berghahn Books, 1994.

Bessel, Richard. Germany after the First World War. Oxford: Clarendon Press, 1993.

Bigongiari, Dino. Introduction to The Political Ideas of St. Thomas Aquinas. New York: The Free Press, original copyright 1956, 1997 edition used here.

- "The Political Ideas of St. Augustine," from the lecture series, The Philosophical and Political Background of the Divine Comedy, reprinted in the Appendix of St. Augustine, The Political Writings. Regnery Publishing: Washington, D.C., 1962, 1996 paperback edition used here. 
Blackbourn, David. Class, Religion and Local Politics in Wilhelmine Germany: The Center Party in Württemberg before 1914. London: Yale University Press, 1980.

- Marpingin: Apparitions of the Virgin Mary in Nineteenth Century Germany. New York: Alfred A. Knopf, 1994.

- The Long Nineteenth Century: A History of Germany, 1780-1918 New York and Oxford: Oxford University Press, 1998.

Bleuel, Hans Peter and Ernst Klinnert. Deutsche Studenten auf dem Weg ins Dritte Reich. Ideologien-Programme-Aktionen, 1918-1935. Guterslöh: Sigbert Mohn, 1967.

Broderick, Roderick C. (ed.) A to $Z$ Guide to the Catholic Faith. Nashville: Thomas Nelson Publishers, 2005.

Cary, Noel. The Path to Christian Democracy: German Catholics and the Party System from Windthorst to Adenauer. Cambridge and London: Harvard University Press, 1996.

Clemens, Gabriele. Martin Spahn und der Rechtskatholizismus in der Weimarer Republik. Mainz: Matthias-Grünewald-Verlag, 1983.

Cornwall, John. Hitler's Pope: The Secret History of Pius XII. New York: Viking Penguin, 1999.

Craig, Gordon. Modern Germany 1866-1945. New York and Oxford: Oxford University Press, 1978.

Cramer, Kevin. "The Cult of Gustavus Adolphus: Protestant Identity and German Nationalism." In Protestants, Catholics and Jews in Germany, 1860-1914. Helmut Walser Smith (ed.) Oxford and New York: Berg, 2004.

Dalton, Margaret Stieg. Catholicism, Popular Culture and the Arts in Germany, 1880-1933. Notre Dame: University of Notre Dame Press, 2005.

Davies, Alan. Infected Christianity: A Study of Modern Racism. Kingston and Montreal: McGill-Queen's University Press, 1988. 
Eley, Geoff. From Unification to Nazism. London: Routledge, 1986.

Ericksen, Robert P. Theologians under Hitler: Gerhard Kittel/Paul Althaus/Emanuel Hirsch. New Haven and London: Yale University Press, 1995.

Evans, Lovell Ellen. The German Center Party: 1870-1914. A Study in Political Catholicism. Carbondale: Southern Illinois University Press, 1981.

Fritzsche, Peter. Germans into Nazis. Cambridge and London: Harvard University Press, 1988.

Fulbrook, Mary. History of Germany 1918-2000: The Divided Nation (Second Edition). Malden, Oxford and Carlton: Blackwell Publishing, 2002.

Gellner, Ernest. Nations and Nationalism. Ithaca: Cornell University Press, 1983.

Giles, Geoffrey. Students and National Socialism in Germany. Princeton: Princeton University Press, 1985.

Gladen, Paulgerhard. Gaudeamus igitur. Die studentischen Verbindungen einst und jetzt unter Mitarbeit von Ulrich Becker. Munich: Callwey, 1986.

- Geschichte der studentischen Korporationsverbände. Vol. II. Würzburg: Becker Verlag, 1981.

Gölucke, Friedhelm (ed). Korporationen und Nationalsozialismus. Schernfeld: SH-Verlag, 1990.

Goldhagen, Daniel Jonah. A Moral Reckoning: The Role of the Catholic Church in the Holocaust and its Unfulfilled Duty of Repair. New York: Alfred E. Knopf, 2002.

Grimm, Horst and Leo Besser-Walzel. Die Corporationen: Handbuch zu Geschichte. Daten.Fakten.Personen. Frankfurt am Main: Umschau-Verlag, 1986. 
Grosby, Steven. "Nationalism and Religion." In Understanding Nationalism. Montserrat Guibernau and John Hutchinson (editors). Oxford: The Polity Press, 2001.

Gross, Michael B. The War Against Catholicism: Liberalism and the AntiCatholic Imagination in Nineteenth Century Germany. Ann Arbor: University of Michigan Press, 2005.

- "The Catholic Missionary Crusade and the Protestant Revival in Nineteenth Century Germany." In Protestants, Catholics and Jews in Germany. 1800-1914. Helmut Walser Smith (ed.) Oxford and New York: Berg, 2004.

Hastings, Adrian. The Construction of Nationhood: Ethnicity, Religion and Nationalism. Cambridge: Cambridge University Press, 1997.

Healy, Rósín. "Anti-Jesuitism in Imperial Germany: The Jesuit as Androgyne." In Protestants, Catholics and Jews in Germany. 1800-1914. Helmut Walser Smith (ed.) Oxford and New York: Berg, 2004.

Heither, Dietrich, Michael Gehler, Alexandra Kurth and Gerhard Schäfer. Blut und Paukboden: Eine Geschichte der Burschenschaften. Frankfurt am Main: Fischer Taschenbuch Verlag, 1997.

Herf, Jeffrey. Reactionary Modernism. Technology, Culture and Politics in Weimar and the Third Reich. Cambridge: Cambridge University Press, 1984.

Holborn, Hajo. A History of Modern Germany 1648-1840. Princeton: Princeton University Press, 1966.

Hölscher, Lucian. "The Religious Divide: Piety in Nineteenth Century Germany." In Protestants, Catholics and Jews in Germany. 18001914. Helmut Walser Smith (ed.) Oxford and New York: Berg, 2004.

Hürten, Heinz. Kurze Geschichte des deutschen Katholizismus 18001960. Mainz: Mathias-Grünewald-Verlag, Mainz, 1986. 
Jarausch, Konrad H. Deutsche Studenten: 1800-1970. Frankfurt am Main: Suhrkamp Taschen Verlag, 1989.

Kater, Michael. "The Work Student: A Socio-Economic Phenomenon of Early Weimar Germany." Journal of Contemporary History 10 (1975): 71-95.

Kolb, Eberhard. The Weimar Republic. London and New York: Routledge, 1988.

Koonz, Claudia. The Nazi Conscience. Cambridge and London: The Belknap Press of Harvard University, 2003.

Krieg, Robert A. Catholic Theologians in Nazi Germany. New York and London: Continuum, 2004.

- Karl Adam: Catholicism in German Culture. Notre Dame: University of Notre Dame Press, 1992.

- Romano Guardini: Proclaiming the Sacred in the Modern World. Liturgy Training Publications, 1995.

Lewy, Guenter. The Catholic Church and Nazi Germany. Da Capo Press, 1964, 2000 edition used here.

Lönne, Karl-Egon. "Germany." In Political Catholicism in Europe, 19181965. Tom Buchanan and Martin Conway (eds.) Oxford: Clarendon Press, 1965.

Lukens, Michael B. "Joseph Lortz and a Catholic Accommodation with Nationalism." In Betrayal: German Churches and the Holocaust. Robert J. Ericksen and Susannah Heschel (eds.) Minneapolis: Fortress Press, 1999.

Marx, Anthony. Exclusionary Origins of Nationalism. Oxford: Oxford University Press, 2003.

Mommsen, Hans. The Rise and Fall of Weimar Democracy. Chapel Hill and London: University of North Carolina Press, 1996. 
Mockenhaupt, Hubert. "Franz Hitze (1851-1921." In Zeitgeschichte in Lebensbildern: Aus dem deutschem Katholozismus des. 20 Jahrhunderts. Herausgegeben von Rudolf Morsey. Mainz: Matthias-Grünewald-Verlag, 1973.

Morsey, Rudolf. Der Untergang des politischen Katholizismus: Die Zentrumspartei zwischen Selbstverständnis und "Nationaler Erhebung” 1932/33. Stuttgart and Zürich: Belser Verlag, 1977.

- "Die deutschen Katholiken und der Nationalstaat zwischen Kulturkampf und Ersten Weltkrieg." Historisches Jahrbuch 90 (1970): 31-64.

Mosse, George. The Crisis of German Ideology: Intellectual Origins of the Third Reich. New York: Grosset and Dunlap, 1964.

- Fallen Soldiers. Reshaping the Memory of the World Wars. Oxford and New York: Oxford University Press, 1990.

Nipperdey, Thomas. Religion im Umbruch. Deutschland, 1870-1918. Munich: C.H. Beck Verlag, 1988.

O'Meara, Thomas F, O.P. Church and Culture: German Catholic Theology, 1860-1914. Notre Dame and London: University of Notre Dame Press, 1991.

- Erich Przywara, S.J.: His Theology and His World

Orlow, Dietrich. A History of Modern Germany, 1871-Present (Third Edition). New Jersey: Prentice Hall, 1995.

Paolucci, Henry. Introduction to St. Augustine. The Political Writings. Regnery Publishing: Washington D.C., 1962, 1996 paperback edition used here.

Peukert, Detlev K. The Weimar Republic: The Crisis of Classical Modernity. New York: Hill and Wang, 1983, first paperback edition of 1993 used here.

Phayer, Michael. The Catholic Church and the Holocaust, 1930-1945. Bloomington and Indianapolis: Indiana University Press, 2000. 
Poiger, Uta G. Jazz, Rock and Rebels: Cold War Politics and American Culture in a Divided Germany. Berkeley, Los Angeles and London: University of California Press, 2000.

Rahden, Till van. "Unity, Diversity and Difference: Jews, Protestants and Catholics in Breslau Schools During the Kulkturkampf." In Protestants, Catholics and Jews in Germany, 1800-1914. Helmut Walser Smith (ed.) Oxford and New York: Berg, 2001.

Remy, Steven P. The Heidelberg Myth: The Nazification and Denazification of a German University. Cambridge and London: Heidelberg University Press, 2002.

Reuth, Ralf Georg. Goebbels. San Diego, New York and London: Harcourt, Brace \& Company, 1993.

Rösgen, Hans Jürgen. Die Auflösung der katholischen Studenten Verbände im Dritten Reich. Dortmunder Historische Studien. Bd. 15. Universitätsverlag Dr. N. Brockmeyer, 1995.

Ruff, Edward Mark. The Wayward Flock, Catholic Youth in Postwar West Germany, 1945-1965. Chapel Hill and London: The University of North Carolina Press, 2005.

Schäfer, Gerhard. "Studentische Korporationen im Übergang zum deutschen Faschismus." 1999 Zeitschrift für Sozialgeschichte des 20. und 21. Jahrhunderts 3 (1988).

Schneck, Stephen Frederick. Person and Polis: Max Scheler's Personalism as Political Theory. Albany: State University of New York Press, 1987.

Schörnig, Michael. "Der Papst in Bayern: "Hier, bin ich wirklich zu Hause." Academia (May 2006): 280.

Schwarz, Jürgen. Studenten in der Weimarer Republik: die deutsche Studentenschaft in der Zeit von 1918 bis 1923 und ihre Stellung zur Politik. Berlin: Duncker \& Humblot, 1971.

Sheehan, James. German History. 1770-1866. Oxford: Clarendon Press, 1989. 
Sklorz, Norbert. Die politische Haltung der Academia 1918-1935. Herausgegeben von F. Golücke. Würzburg: Veröffentlichung des Archivvereins der Markomannia, 1980.

- "Der Krieg gegen den Terror ist gescheitert." Academia (May 2006): 280

Snyder, Louis. Roots of German Nationalism: The Sources of Political and Cultural Identity 1815-1976. New York: Barnes and Noble Books, 1978.

Spicer, Kevin P. Resisting the Third Reich: The Catholic Clergy in Hitler's Berlin. Dekalb: Northern Illinois Press, 2004.

Spohn, Winfried. "Religion and Working-Class Formation in Imperial Germany, 1871-1914." In Society, Culture and the State in Germany, 1870-1930. Geoff Eley (ed). Ann Arbor: University of Michigan Press, 1996.

Steigmann-Gall, Richard. The Holy Reich. Nazi Conceptions of Christianity, 1919-1945. Cambridge: Cambridge University Press, 2003.

Steinberg, Michael Stephen. Sabers and Brown Shirts: The German Students' Path to National Socialism. Chicago: University of Chicago Press, 1973.

Stern, Fritz. The Politics of Cultural Despair: A Study in the Rise of the Germanic Ideology. Berkeley, Los Angeles and London: University of California Press, 1961, 1974 paperback edition used here.

Stitz, Peter. Der CV 1918-1939. Der hochschulpolitische Weg des Cartellverbandes der Katholischen deutschen Studentenverbindungen (CV) vom Ende des 1. Weltkrieges bis zur Vernichtung durch den Nationalsozialismus. Munich: Herausgegeben von der Gesellschaft für Studentengeschichte und studentisches Brauchtum e.V., 1970.

Toews, John Edward. Becoming Historical: Cultural Reformation and Public Memory in Early Nineteenth-Century Berlin. Cambridge: Cambridge University Press, 2004. 
Vogel, Wieland. Katholische Kirche und Nationale Kampfuerbände in der Weimarer Republik. Mainz: Matthias Grünewald, 1989.

Waibel, Paul. Politics of Accommodation: German Social Democracy and the Catholic Church, 1945-1959. Frankfurt am Main and Bern: Peter Lang, 1983.

Warloski, Ronald. Neudeutschland, German Catholic Students, 19191939. The Hague: Martinus Nijhoff, 1970.

Windell, George C. The Catholics and German Unity, 1866-1871. Minneapolis: University of Minnesota Press, 1954.

Wehler, Hans-Ulrich. The German Empire 1871-1918. Lemington Spa, Hamburg and New York: Berg Publishers, 1985.

Wiederstand und Vervolgung im C.V. Die im zweiten Weltkrieg gefallenen CVer. Munich: Eigenverlag von der Gesellschaft für Studentengeschichte und studentisches Brauchtum e.V., 1983.

Winter, Julie. Luther Bible Research in the Context of Volkish Nationalism in the Twentieth Century. New York: Peter Lang, 1998.

Zahn, Gordon C. German Catholics and Hitler's Wars. New York: E.P Dutton \& Co, 1969.

Zalar, Jeffrey T. "The Process of Confessional Inculturation: Catholic Reading in the Long Nineteenth Century." In Protestants, Catholics and Jews in Germany. 1800-1914. Helmut Walser Smith (ed.) Oxford and New York: Berg, 2004.

\section{Primary Sources}

Academia / Schwarzes Brett 32 (1919): 148.

Abmahr, Kaplan. "Lehramtspraktikant August Aichinger, Ae." Academia 31 (November 15, 1918): 149-150.

Aquinas, Thomas. The Political Ideals of St. Thomas Aquinas. Dino Bigongiari (ed.). New York: The Free Press, 1997. 
Aristotle, Politics. Mineola: Dover Publications, 2000.

St. Augustine, The City of God. New York: The Modern Library, 2000.

Baur, Univ. Prof. Dr. Ludwig. "Gedächtnisrede auf die Gefallenen. Gehalten in der Trauerkneipe der Alamannia am Samstag, 22. Februar." Akadem. Monatsblätter 31 (April 25, 1918): 64-66.

Baus, von reg. und Elimar Hoffman. "Wir und die Anderen." Academia 37, Nr. 10 (February 15, 1932): 128.

Bahr, Hermann. "Im Zeichen Weimars." Wiederbegegnung von Kirche und Kultur in Deutschland. Eine Gabe für Karl Muth. Munich, 1927.

Bell, Dr. Hans, Reichsminister. "Gedanken über Staat und Parität." Academia 43, Nr. 6 (15 November 1930): 191-192.

Berger, Hans. "Korporation, Hochschule und Akademikerschaft." Der Ring 5 (Feb/March, 1929): 107.

Berger, Dr. R. "Einigung aller deutchen Akademiker," Akadem. Monatsblätter 37 (October 1924): 29.

Berning, Dr. "Die Konservative Wendung in der Jugend und die Rechtsradikale Gefahr." Unitas 70, Nr. 11/12 (August-September 1930): 181. Also appearing in Akadem. Monatsblätter 43, Nr. 1 (October 1930): 93-99.

Bible, The New American. Nashville: Catholic Bible Press, 1987.

Bigge, Matthias Maria, O.P. "St. Thomas von Aquin, Zum 600 Jahrestag seiner Heligsprechung.” Unitas 63, Nr. $7 / 8$ (April/May 1923): 109-111.

Bloem, Walter. "Zehn Gebote für den deutschen Studenten." Academia 35, Nr. 1/2 (May-June 1922): 9-10.

Bremser, Hans. "Krise der Gegenwart." Der Ring 4, \#89 (November 1928): $79-81$. 
Buchner, Dr. Max. "CV und Politik." Academia 32. Nr. 11 (25 March 1920): 319-320.

Busch ("Seinem Bundesbruder"). "Karl Hubert Joseph Klein." Academia 32 (25 March 1920): 340-41.

Bussman, Josef, Diplomvolkswirt. "Aufgaben und Aufmarsch der katholischen deutschen Jugend.” Der Ring 7, 1/3 (March 1930): 4-7.

C.V. Handbuch. Herausgegeben von der Gesellschaft für Studentengeschichte und studentisches Brauchtum e.V. Regensburg, 2000.

Derichsweiler, P., Mitglied des Arbeitauschusses im Auschuss für die Errichtung eines Schlageter-National-Denkmals. "Das Schlageter-Ehrenmal in Düsseldorf kommt." Academia 42 (15 November 1929): 222-224.

Diehl, Alfred. "Der Gewerbliche Mittelstand im Kampfe gegen Kapitalismus und Sozialismus, Eine Zeitbetrachtung." Academia 33, Nr. 2 (June 21, 1920): 31-33.

Dobek, "Otto Lühr.” Akademischer Monatsblätter (15 October 1919): 127.

Donders, Dr. U. "Weihnachten 1918: Aufblick zum Stern von Bethlehem." Unitas 59 (December 1918): 49-52.

Ehlen, Nikolaus. "Vom wirtschaftlichen Wollen der neuen Jugend." Academia 35 (May-June 1922): 2.

Eichmann, Dr. Eduard, Universitätsprofessor. "Das Reichskonkordat und wir." Academia 46, Nr. 4 (August 15, 1933): 90-91.

Ernst, Dr. "Katholizismus und Politik: Grundzätsliche Erwagungen." Academia 40, Nr. 6 (October 15, 1927): 136-142.

Färber, Dr. D. "Nationalismus." Academia 32, Nr. 11 (March 25, 1920): 312. 
Faulhaber, Kardinal Dr. von, 23. Thesen Sr. Eminenzes. "Deutsches Ergefühl und katholisches Gewissen." Academia 46, Nr. 12 (April $15,1924): 61-62$.

Forschbach, Edmund. "Aufruf des Führers an den CV." Academia 46 (July 15, 1933): 58.

- "Die Verfassung des CV." Academia 46, Nr. 6/7 (October/November 1933): 147-148.

Gibl, Univ. Prof. Hans. "Volk, Staat und Kirche." Akadem. Monatsblätter 44, Nr. 1 (October 1931): 138-139.

Gleich, Dr. Leonard, Vortrag gehalten auf der Morgensitzung des 1. W.S. Vereinfestes des. U.V. München, "Moderne Kriegsliterature und Fronterlebnis." Unitas 70 (January 1930): 57-62.

Griese, Theol H. "Joseph Holling, stud. theol." Unitas (July 1919): 167.

Hagen, Herrmann. "Albert Leo Schlageter." Academia 46 (15 May 1933): $12-17$.

- "Die Beschlüsse der 61. CV-Versammlung, zusammengestelt von." Academia 45, Nr. 6 (September 15, 1932): 137-138.

Halsar, K. cand. Phil. "Die deutschen Minderheiten in Europa." Academia 41, Nr. 2 (June 15, 1928): 29-31.

Hastler, Jos. "Ludwig Hastler, GW." Academia 31 (December 15, 1918): 176.

Haupt, Hermann. Handbuch für den Deutschen Burschenschaften. Giessen. 1926.

Hebing, Richard. "Akademikernot - Wirtschaftskrise - Lebensraum." Unitas 72, Nr. 10 (July 1932): 126-129.

Hegel, Georg Wilhelm Friedrich. The Philosophy of History. New York: Dover Publications, 1956.

Herkenrath, Cand. phil. Leutnant. "Dr. med. Adolf Schwarz." Unitas 59 (December (1918): 47-48. 
Hermens, Aloys, "Der 30. November und seine Folgen." Unitas 68 (March/April 1928): 83-86.

- “Kritik des Kapitalismus." Unitas 69, Nr. 7 (April 1929): 89-90.

Hersting, Dr., Sen. Rat. "Verband Politik." Akadem. Monatsblätter 37, \#1 (October 1924): 52-58.

Hoeber, Karl. Handbuch für Mitglieder des Verbandes der kath. Studentenvereine Deutschlands. Cologne, 1921.

Hoppe, G. "Der Paul Kalkum AlsM." Academia 32 (25 March 1920): 339-340.

Hub, Hawl, cand. phil. "Vom Verstehen unserer Grundsätze." Der Ring 3 (Nebelung/November 1927): 91-92.

Hunele, Sanitätsrat Dr. "Christlicher Akademiker und politisches Leben." Academia 32, Nr. 1/2 (15 June 1919): 2-7.

Jünger, Ernst. The Storm of Steel. From the Diary of a German StormTroop Officer on the Western Front. New York: Howard Fertig, 1996.

Kaupel, Dr. H, Privatdozent. "Prinzipien zum antisemitischen Kampf gegen das Alte Testament." Unitas 72, Nr. 5 (February 1932): 56.

K.H. "Kriegsbriefer gefallener CVer. Aus dem Buche von Witkop, Kriegsbriege gefallener Studenten (f.S. 197)." Academia 42 (15 November, 1929): 129.

K.H. "Feldbriefer katholische Soldaten." Akadem. Monatsblätter 8 (December 15, 1918): 20.

Klenbolte, Rechtsanwalt. "Parteinpolitiker - Hände weg vom Kartellverband!" Unitas 37, \#8 (May 1925): 305-309.

Knecht, Josef. "Michael Messerschmidt." Academia 32 (25 March 1920): 343. 
Kohnen, Oberlehrer Dr. "Christlich-National." Academia 33, Nr. 5 (20 September 1920): 117-118.

Kolassa, Dr. St. "Med. Karl Schnurch." Academia 32 (25 March 1920): 347.

Kosch, Wilhelm. "Die Erneurungsbewegung in der katholischen deutschen Studentenschaft." Das Neue Reich VIII (1926): 661.

Krausneck, Dr. W. "Festrede zum 60. Stiftungsfest der Walhalla Gehalten auf dem Festkommers vom." Akadem. Monatsblätter 37, Nr. 7 (April 1925): 246.

Krauthausen, Udo, Dr. jur. "Dem Cartellverband am Rhein seinem Kämpfern für Deutschlands Ehre." Academia 43, Nr. 5 (September 15, 1930).

Kremser, Josefine. "Katholische Politik - Streiflichter." Die katholische Studentinin: Organ des verbandes der kath. Studentinen Vereine Deutschlands 9 (July 1922): 6-11.

Lemmer, Dr. J. "Volk und Reich." Festrede, gehalten auf der Reichsgründungsfeier der Trierer Akademiker am 21. Januar 1931. Der Ring 7, Nr. 1/3 (March 1931): 1.

Luible, Dr. Martin. "Student in Not." Akadem. Monatsblätter (25 May 1921): 96.

- "Staat und Volk als Gemeinschaft." Akdem. Monatsblätter Nr. 8 (May 25: 1924): 83-84.

Maier, Dr. Theol. Johannes. "Felddivisionpfarrer Bernhard Kowalski." Academia 32 (25 March 1920): 341.

Mailer, Carl, "Die Weltanschauung Rathenaus." Aus einem Festvortrag, gehalten auf einer Morgensitzung des U.V. München von stud. phil. Unitas 68, Nr. 11/12 (August 1928): 173-174.

Mais, Dipl-Ing. Studienrat in Köln. "Die Not der akademischen Jugend." Academia 31, Nr. 3 (25 July 1921): 61-62. 
Mayer, Ernst. "Das erste Jahr nach dem Kriege." Akadem. Monatsblätter (15 October 1919): 128.

Monzel, Heinz. "Der Weg der Unitas." Worte, gesprochen auf dem Osterkommers des U.V. 1933 in Köln von. Unitas 73, Nr. 8/9 (May/June 1933): 82-84.

Müller, Dr. Franz. "Vom Wesen des Politischen und Sozialen. Aus Anlaß einer Begriffsbestimung der Sozialpolitik." Unitas 73, Nr. 1 (October 1932): 1-7.

- Referat gehalten aus der 65 G.V. des Unitas Verbands zu Duisburg 1928 von. Unitas 86, Nr. 10 (July 1928): 150-152.

Nuß, August. “Und Wir?” Academia 31 (December 15, 1918): 178-179.

- "Der politische Radikalismus auf den deutschen Hochschulen," Academia 45, Nr. 2 (June 15, 1932): 42-44.

Oberthür, Adalbert. "Katholizismus und Vaterlandsliebe." Unitas 66 (June 1926): 173.

Pieper, Dr. Lorenz. "Alfons Pieper." Academia 32 (25 March 1920): 345.

Planz, Theol. P. "Unitas und Gegenwart." Unitas 73, Nr. 8/9 (May/June 1933): 85-86.

Plum, A.H. Festrede von, "Nun laß die Glocken von Turm zu Turm Durchs Land frohlocken im Jubelsturm." Unitas 70 (August/September 1930): 11-14.

Pölnitz, Dr. G. Frh. Von. "Katholisch und Deutsch." Akadem. Monatsblätter 45, Nr. 7 (June 1933): 289-290.

Port, Hermann. "Römischer Katholizismus und politische Form," Akadem. Monatsblätter 37, \#8 (May 1925): 302-305.

Rath, Emil. "Der korrekte Fuchs." Academia 34 (Nov-Dec. 1921): 21. 
Reger, August, durch Beschluss der 61. CV-Versammlung wurden hier folgenden Richtlinien für die Arbeit des $\mathrm{CV}$, seiner Verbindungen und seiner Estelle auf dem Gibbeted der Pelage deutschen Colostrums des CV festgelegt. "CV und deutsches Volkstum." Academia 45, Nr. 5 (September 15, 1932): 142-144.

Reinele, von. "Demokratie." Academia 32, Nr. 12 (25 April 1920): 357360 .

Remarque, Erich Maria. All Quiet on the Western Front. New York: Fawcett Crest, 1928.

Riedmatter, Kaplan V. "Unsere drei Prinzipien als Erzieher zur Volksgemeisnschaft." Akadem. Monatsblätter 37, Nr. 1 (October 1924): 60-62.

Rüdinger, Phil. "Unitas und Zeitenwende." Unitas 73, Nr. 8/9 (May/June 1933): 81-82.

Schas, Hans. "Dr Franz Laarmann, cand. phil." Unitas 58 (August 1918): 199-200.

Schlund, Erhard. "Katholik und Vaterland." Academia 44, Nr. 3 (June 15, 1931): 22-24.

- "Zur Frage der Arbeitsgemeinschaft der katholischen deutschen Studentenverbände." Academia 33 (20 July 1920): 61.

- "Katholizismus und Nationalismus." Academia 39, Nr. 2 (June 15, 1926): 27.

- "Zur Rassenfrage." Academia 40, Nr. 3 (July 15, 1927): 53-56.

- "Der Kriegsroman und die Religion im Kriege." Academia 42 (15 August 1928): 87-90.

- "Die Religion im Kriege und in den Kriegsbüchern." Academia 42 (15 November 1929): 193-199.

- "Kann ein Mitglied des C.V. Sozialdemokrat sein?" Academia 41, Nr. 3 (15 July 1931): 70-74. 
- "Der Sieg der Bolshewismus über die Kirche in Rußland." Academia 44, Nr. 9 (January 14, 1932): 236-239.

- "Katholizismus und Nationalismus." Academia 44, Nr. 3 (June 15, 1931): 22-23.

- "Die Religion in Programm u. Praxis der Nationalsozialist Deutsch. Arbeiterpartei." Academia 44, Nr. 3 (July 15, 1930): 56.

- "Nationalsozialismus und Studentenschaft." Academia 43, Nr. 10 (February 15, 1931): 292-293.

Schmidt, Dr. Paul. "iur. Otto Faesche, Sal." Academia 31 (December 15, 1918): 176.

Seissert, Von. iur. "Zum Kampf um den Hochschulring." Academia 34, Nr. 11/12 (March-April 1922): 261.

Siedler. "Eduard Hartmann, MM, SS, Vc." Academia 31 (15 December 1918): 176.

Steinbüchel, Prof. Dr. Theodor. "Katholischer Akademiker und Sozialismus," Unitas 70, Nr. 3 (December 1929): 37-43.

Steinrötter, Alfons and Horst Emscher. "Die politische Situation und Staatsphilosophie. Um die Einheit der neudeutschen Geistentwicklung." Akadem. Monatsblätter 43, Nr. 1 (October 1930): 296-299.

Stracke, Von Referander iur. "Die Beruf Stände von Handel, Handwerk und Gewerbe und der Wiederaufbau Deutschlands." Academia 34, Nr. $7 / 8$ (Nov-Dec. 1921): 201-202.

Stratmann, P. Franziskus, O.P. "Weltkirche und Weltfriede." Academia 28, Nr. 2 (July 15, 1925): 61-62.

Striewe, Bernd. "Der Bankrott des akademischer Hochschullebens in Deutschland." Akadem. Monatsblätter XXXII, Nr. 1/2 (25 November 1919: 1-2

Ternik, Walter. "Der christliche Volkstaat." Academia 45, Nr. 7 (Nov. 15, 1932): 190-191. 
- "Volkstum, Reich und Heimat!" Academia 45, Nr. 10 (Feb. 15, 1933): 274-275.

Thieron, Rob. "CV und Hochschulring deutscher Art." Academia 34, Nr. 5 (July 25, 1921): 97.

Timpe, Professor Dr. A. "Vaterlandsliebe und Pazifismus." Unitas 66, Nr. 2 (November 1925): 25-27.

- "Vortrag auf dem Festkommers des Unitas-Verbandes anläßlich der 63 Generalversammlung der Katholiken Deutschlands in Hannover." Unitas 63, Nr. 11/12 (September 1924): 163.

- "Die religiösen Aufgaben der Unitas in der heutigen Zeit," Festansprache, gehalten auf der Morgensitzung des. U.V. Berlin am 19. Februar 1933 von Hochschulprofesor Dr. A. Timpe. Unitas 73, Nr. $8 / 9$ (May/June 1932): 87-89.

- "Volksdeutsche Erziehung des Akademikers," Unitas 67 (October/November 1926): 1.

Timpe, Dr. Heinrich. "Auslandsdeutsche und Auswanderung," Rede des Studiendirektors Dr. Heinrich Timpe, Hamburg (A.H. UnitasFrisia) auf dem Katholikentag zu Hannover am 2. Sept. 1924. Unitas 65, Nr. 2 (November 1924): 13-17

Tischleder, Dr. V. "Der katholische Staatsgedanke als Echo der ursprünglichen gefundenen katholischen Wesenmitte." Akadem. Monatsblätter 44, Nr. 1 (October 1931): 120-126.

Türk, Dr. "Die Einweihung des Schlageter-Nationaldenkmals in Düsseldorf am 23. Mai." Academia 44 (15 July 1931): 72.

Vincke, J. "Dr. Wilhelm Schwermer," Unitas 59 (August 1919): 224-225.

— "Lotsenruse." Unitas 5 (August 1921): 129.

Voß, Franz. "Der med. Karl Kellner PG." Academia (25 March 1920): 340. 
Walter, Anton J., Cand. Phil. "Der Lueger als Noriker: Eine Bürgermeisterrede von 25 Jahren." Academia 39, Nr. 10 (February 15, 1927): 198-200.

Weber, Franz. Generalsekretär des Augustinus-Verein zur Pflege der katholischen Press, Leiter des Pressamtes des Ringes Katholischer Deutscher Burschenschaften (untitled article). Der Ring 6, Nr. 8/9 (November 1930): 99-101.

Weber, Max. The Protestant Work Ethic and the Spirit of Capitalism. London and New York: Routledge, 1992.

Weibeler, Stud. phil. "Dr. phil. Bernhard Hinteler." Unitas 59 (August 1919): 221.

Wien, Rob. "Unsere A.M. in Gefahr!" Akadem. Monatsblätter XXXV (15 May 1923): 33-34.

Winkler, Dr. Wilhelm. "Eine Erwiderung." Academia 38, \#3 (July 15, 1925): 62-63.

Zanders, Dr. Josef. "Zum Geleit.” Der Ring 1 (November 1924): 2.

Zeck, K. “Karl Shotter, stud. phil." Unitas 60 (January 1920): 66-67.

Zwierlein, Jakob. “Amtsanwalt Dr. Heinrich Schmitt.” Academia 32 (25 March 1920): 346.

Author unknown. "Ansprachen und Reden bei der 67 G.V. der Unitas in Aachen." Unitas 70, Nr. 1 (Aug./Sept. 1930): 10.

Author unknown. "Bericht der Westdeutsch. Rundschau." Julifolge Mr. 15, 2 10-11 über den Vortrag von Professor Dr. Schmaus vor der Fachschaft der kathol. Theologen a.d. Universität zu Münster. "Begegnung zwischen katholischen Glauben und nationalsozialistischer Weltanschauung." Academia 45, Nr. 4 (August 15, 1933): 91-92.

Author unknown. "Brunno Rossmann" (Von seinem Leibburschen). Academia 32 (25 March 1920): 346. 
Author unknown. "CV und Nationalsozialismus." Academia 44, Nr. 12 (April 15, 1932): 333.

Author unknown. "CV und Nationalsozialismus." Academia 45, Nr. 12 (April 15, 1933): 351.

Author unknown. "Die katholische Jugend gegen den NationalSozialismus." Akadem. Monatsblätter 43, Nr. 1 (October 1930): 388-389,

Author unknown. "Die katholische Studentenverbände auf der 69. Generalversammlung der Katholiken Deutschlands in Münster i.W." Academia 43, Nr. 6 (15 November 1930): 178-180.

Author unknown. "Die nationale Erhebung und der katholische Akademiker, eine Stimme der Jugend." Academia 46, Nr. 2 (June 15, 1933): 36-37.

Author unknown. "Der CV im Weltkrieg 1914-1918." Academia 31 (December 15, 1918): 182.

Author unknown. "Der Novembervorgänge an der Münchener Universität." Academia 36, Nr. 5-8 (December 15, 1923): 17-18.

Author unknown. "Der Volksbund Deutsche Kriegsgräberfürsorge." Academia 45 (15 November 1932): 183.

Author unknown. "Deutschland und der Papst (aus einem Organ der D.St.)" Akadem. Monatsblätter 44, Nr. 1. (October 1931): 23.

Author unknown. "Dr. Adolf Kardinal Bertram, Fürstbischof von Breslau.” Unitas 60 (January 1920): 61-66.

Author unknown. "Ein CVer von Nationalsozialisten niedergeschlagen." Academia 44 (October 15, 1931): 167.

Author unknown. "Eine Theologie des Nationalsozialismus." Unitas 72, Nr. 10 (July 1932): 131-135.

Author unknown. "Gegenwartsaufgaben des katholischen Korporationsstudentenen: Anläßlich des 31 Aitrag." Augsburger Postzeitung 4, \#107 (10 May 1930). 
Author unknown. "Hindenburg." Der Ring 3 (Nebelung 1927): 89.

Author unknown. "Hochschulring deutscher Art." Unitas 61, \#3 (April 1921): 61-62.

Author unknown. "Joseph Küpper" (Gerichtsreferander). Academia 32 (25 March 1920): 342.

Author unknown. "Kartellbrüder! Vergesst nicht die Danziger Hochschule!." Akadem. Monatsblätter XXXII, Nr. 11/12 (September 25, 1920): 114.

Author unknown. "Katholische Student und Politik." Academia 32, Nr. 5/6 (15 Sept./Nov. 1919): 152-154.

Author unknown. "Leutnant d.R. cand. theol. Joseph Baule." Unitas 60 (May 1920): 107.

Author unknown. "Oberlehrer Andreas Mertens," Unitas 60 (December 1919): 41.

Author unknown. "Reichskanzler Dr. Heinrich Brüning Bd!" Academia 42, Nr. 12 (15 April 1930): 367.

Author unknown. "Unsere Thesen zur Anchlußfrage." Akadem. Monatsblätter 44, Nr. 8 (June 1932): 313-314.

Author unknown. "Vom Gemeinschaftsgedanken der katholischen Kirche." Unitas 65, Nr. 9 (June 1925): 103.

Author unknown. "Von der Hochschulen, Die Not der deutschen Studenten: Ein Rundgang durch das Studentenheim, Prag." Oktober 1924 (14 December 1924): 94.

Author unknown. "Von der Münchner Studentenschaft." Akadem. Monatsblätter Nr. 6/7 (April 10, 1924): 22-23.

Author unknown. "Zur Lügen von unserer Schuld am Kriege." Akadem. Monatsblätter Nr. 8 (May 25, 1924): 32. 


\section{Electronic}

Cartellverband der katholischen deutschen Studentenverbindungen (CV) http://www.cartellverband.de

Kartellverband der Katholischen Studentenvereine Deutschlands (KV) http://www.kartellverband.net

Verband der Wissenschaftl. Katholische Studentenvereine Unitas http://www.unitas.org

Wiking Chapter of the CV http://www-wiking-hamburg.edu/index.php?id=14 (accessed August 6, 2007)

"Gedankstätte Yad Vashem zeichnet Berlinerin." Berliner Morgenpost (29 July 2003). http://www.morgenpost.de/content/2003/07/29/berlin/619572 .html?redirID (accessed 06/19/2007)

Hanns Seidel Foundation. (Hanns Seidel Stiftung). http://www.hss.de

Elting, Heinz-Hermann, Vizepräsident des Institut Saint Benoît, Patron de l' Europe, "Aus Christlicher Überzeugung zur Europäischen Einigung, Robert Schuman, erster Präsident des Europäischen Parlements (1958-1960)" - based on a lecture given on the occasion of the 30th Congress of the Associatio Sanctus Benedictus Patronus Europae on May 22, 1998 in Cerlvaux, Abtei St. Maurice. Dominu - Université Dominicaine - Bibliothèque en ligne, 8. http://biblio.domuni.org/europe/robertschuman/robertschuman _de.pdf (accessed 07/27/2007)

Beckman, Christof, "Vor 40 Jahren: Gründung der UNITAS Robert Schuman in Bochum Festrede von Bbr. Karl Fürst zu Löwenstein." http://www.unitas-ruhrania.org/seite68.htm (accessed 07/27/2007) 
Hayes, Zachary, O.F.M. Professor of Historical and Doctrinal Studies, Catholic Theological Union. "Pope Benedict XVI: Joseph Ratzinger." http://learn.ctu.edu/Reflections_and_Readings/Pope_Benedict_X VIx_Joseph_Ratzinger_html (accessed 06/18/2007) 


\section{VITA}

Jeremy S. Roethler was born in Los Angeles, California in 1971. UCLA awarded his bachelor's and master's degrees in Political Science in 1992 and 1996, respectively. During his last year of his master's degree program, the teachings of Saul Friedländer, Robert Wohl and Peter Baldwin inspired him to change his directional star. The History Department at the University of Washington (Seattle) was kind enough to admit this completely unproven and untried student of the discipline to its Ph.D. program in 1997. He survived his first years by the grace of patient and forgiving teachers like Uta Poiger, John Toews, Glennys Young, and Sarah Stein, among others. He was also resurrected on more than one occasion by the maternal guidance of Lori Anthony and Susanne J. Young. Timely arriving mentors included James R. Felak. After surviving to tell about his comprehensive exams, he earned his keep as an adjunct instructor at the University of Washington, Seattle and Bothell campuses, at the University of Seattle, Antioch University, Shoreline Community College, and Concordia University (Austin). 